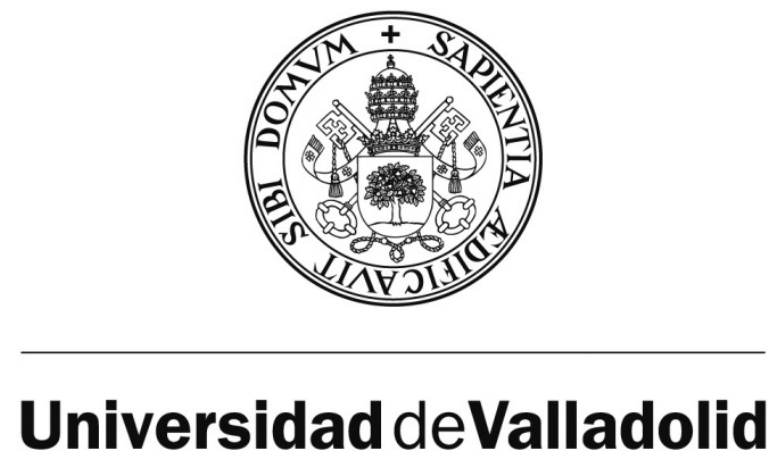

FACULTAD DE MEDICINA

Dpto. de Bioquímica y Biología Molecular y Fisiología.

\title{
Métodos de modificación génica dirigida en células humanas y su aplicación en el Síndrome de Wiskott-Aldrich.
}

Presentada por María Alejandra Bernardi para optar al grado de Doctora por la Universidad de Valladolid.

Dirigida por:

Miguel Ángel de la Fuente García

María Simarro Grande

Valladolid, 2015. 



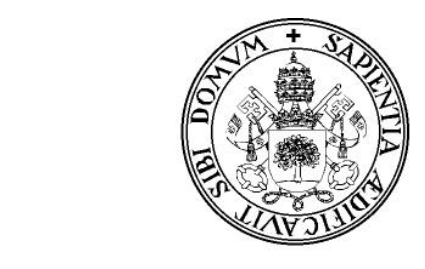

\section{Universidad deValladolid}

\section{AUTORIZACIÓN DEL DIRECTOR DE TESIS}

(Art. 2.1.c de la Normativa para la presentación y defensa de la Tesis Doctoral en la UVa)

D. Miguel Ángel de la Fuente García, con D.N.I. n $12368513 x$, profesor del departamento de Biología Celular, Histología y Farmacología. Facultad de Medicina IBGM, Universidad de Valladolid, y Dña. María Simarro Grande con D.N.I n 33960854C, profesora asociada del departamento de Anatomía Patológica, Microbiología, Medicina Preventina y Salud Pública, Medicina Legal y Forense. Facultad de Medicina, Universidad de Valladolid; como directores de la Tesis Doctoral titulada "Métodos de modificación génica dirigida en células humanas y su aplicación en el Síndrome de Wiskott-Aldrich" presentada por Dña. María Alejandra Bernardi, alumno del programa de doctorado en Investigación Biomédica impartido por el departamento de Bioquímica y Biología Molecular y Fisiología.

Autorizan la presentación de la misma, considerando que el trabajo de Tesis Doctoral que se presenta constituye un trabajo de investigación original y que el doctorando satisfizo todos los requisitos legales y superó con éxito su periodo de aprendizaje y especialización.

Valladolid, 12 de febrero de 2015.

Los directores de la Tesis, 

El trabajo realizado en esta tesis ha sido financiado por:

- Consejería de Educación. Junta Castilla y León (VA244A11-2).

- Instituto de Salud Carlos III. Fondo de Investigación Sanitaria, FIS (PI10/02511).

- Fundación Ramón Areces (CIVP16A1843).

- Beca Eurotango (Erasmus Mundus) de doctorado completo (34 meses).

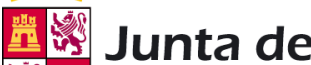
造器 Castilla y León

Consejería de Educación
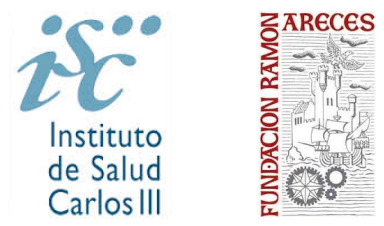

A mi familia 



\section{Agradecimientos}

Estoy convencida que una de las cosas más importantes de esta vida, es ser agradecida, y por ello aquí van estas líneas.

En primer lugar, a Miguel y María, mis directores de tesis, por haberme abierto las puertas del laboratorio, por confiar en mí, por permitirme aprender de ellos, por la paciencia cuando las cosas no salían, por sus consejos y sobre todo por el apoyo personal que me dieron durante todo este tiempo lejos de casa. Ambos hicieron que mi estadía fuera muy cálida y llevadera.

A Laura, quien no sólo fue la que me enseñó mucho de lo que hoy sé, sino que también, entre PCRs y transformaciones, se convirtió en una gran amiga. Gracias por tantos momentos compartidos en Valladolid, en Vigo y también en Nuremberg.

A Rebeca, quién siempre estuvo dispuesta a echarme una mano, y sin la que parte de este trabajo no hubiera sido posible. Por hacer muchas veces de amiga y de madre, por echarme las broncas por las malas comidas y por compartir tantos momentos buenos y no tanto.

A Bea, por estar siempre dispuesta a darme una mano, por esos encuentros de sábado, domingos y noches en el cuarto de cultivo con largas horas de conversaciones de por medio. $Y$ ni hablar de los desayunos y sus palabras de apoyo en cada momento de este duro camino de la ciencia.

A Ginesa, por siempre darme su apoyo, en lo profesional y en lo personal.

A Vicky, por todos los momentos compartidos, las charlas en cultivo y por escucharme siempre y por darme ánimos cuando todo se volvía oscuro en el camino de la tesis. Otra amiga que me deja esta experiencia.

A Nadia por toda la ayuda con los temas tesis y por darme siempre ánimos.

A todos los que forman parte del B7 y del B2, por los cafés, las comidas, las salidas y sobre todo, por todas las risas que siempre tienen para contagiar.

A todos los que forman o formaron parte del IBGM, que han estado siempre que he necesitado.

A todos los que formaron parte del B4 en todos estos años, gracias!

Y luego, agradecer a quienes son parte de mi vida, fuera del IBGM. 
Primero y principal, a mis padres, por hacer que todo esto haya sido posible, en todos los sentidos. Por confiar ciegamente en mí y darme alas para volar. Eternamente agradecida de todo lo que me dieron y me enseñaron, y sobre todo por su amor incondicional. Y junto con ellos, a mis hermanos, que siempre están ahí, apoyándome en todo y siempre positivos ante los retos. Gracias por quererme tanto!

A mi abuelo, una de las personas más influyente y más admirada en mi vida. Gracias por hacer de mí lo que soy, por tu sabiduría, tus conocimientos, por enseñarme que todo se construye con esfuerzo y sacrificio, y que sólo así se puede llegar alto. Gracias por tu apoyo incondicional, y porque sé que estés donde estés, estarías feliz con esto.

A mi abuela, siempre presente, de la que también aprendí que todo se construye con trabajo, mucho trabajo, y dedicación. Una mujer a la que no dejo de admirar.

A los Jova, que están siempre presente, en las buenas y en las malas, que me quieren y me malcrían como a nadie. Porque con ustedes la distancia no se nota!

A Lala y Teté, mi segunda familia y mi segunda casa, siempre! Agradecida de todos los momentos que me dieron! Y a mis hermosos peques que llenan todo de amor!

A los Massa por su cariño y su apoyo incondicional.

A los Gaitán, en especial a Giuli y Arturo por su cariño y apoyo.

A Ana, que siempre me acompaña con sus mensajes y me levanta los ánimos.

A Emi, Estefi y Pichi, Héctor, Moni, Nacho, Caro, Carla y Ale, que fueron mi familia en Valladolid durante estos 4 años. En especial a Estefi y Carla que me dieron una mano enorme en este último tiempo.

A Úrsula, por ser parte de todos los momentos de mi vida en los que tengo recuerdos, como amiga y como hermana, con todo lo que eso implica!

A Belén, Yani, Marian, Nadia y Ceci, mis amigas de siempre, que siguen ahí, acompañándome en cada paso, como si no estuviéramos a $12.000 \mathrm{~km}$ de distancia.

A Sonia, Saray, Alicia y Laura (LEQMM), personas que valen oro y que lo demostraron en los momentos más difíciles de mi estancia en España.

A JP y Belén, por el tiempo compartido, acá y allá. Por hacerme de compañía de transporte, por las charlas, el apoyo y por tener siempre palabras de aliento en este camino.

Finalmente, mi agradecimiento a este país y a toda la gente que de un modo $u$ otro formó parte de mi vida en estos años.jMuchas gracias por 4 años inolvidables! 




\section{IINDIGE.}

"La ciencia se compone de errores, que a su vez, son los pasos hacia la verdad"

Julio Verne (1828 - 1905) 


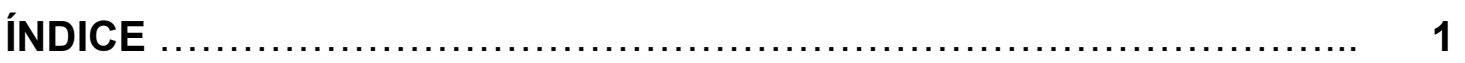

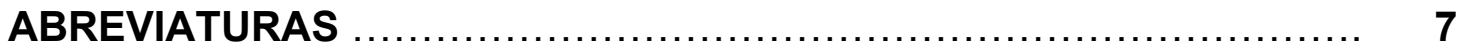

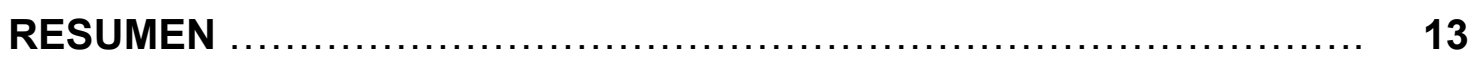

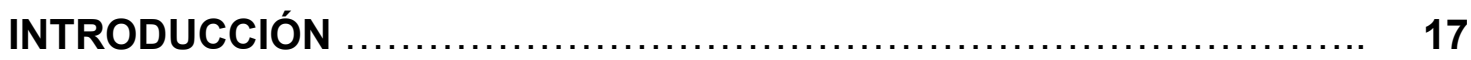

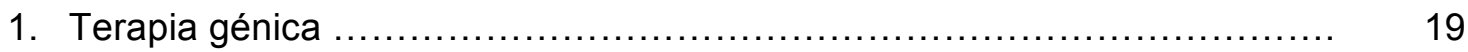

1.1. Definición y clasificación ............................................. 19

1.2. Terapia génica en enfermedades monogénicas ......................... 20

1.3. Criterios para seleccionar una enfermedad monogénica como

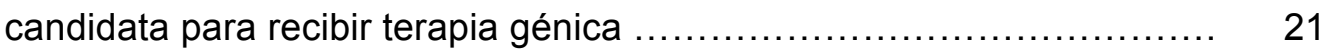

1.4. Mecanismos de reparación del DNA y su intervención en los

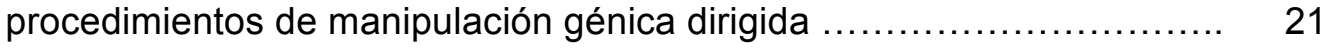

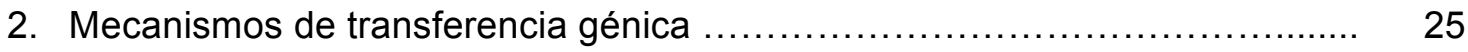

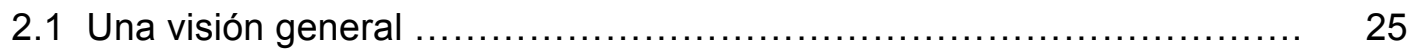

2.2 Métodos virales de transferencia génica .............................. 26

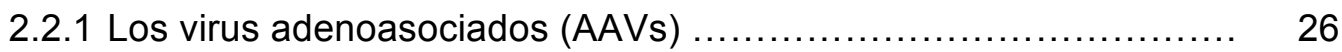

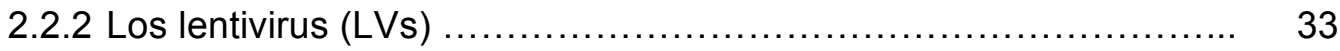

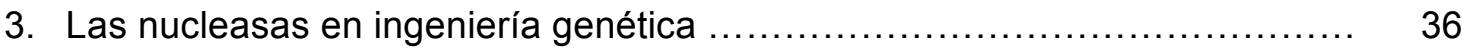

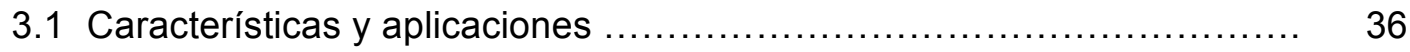

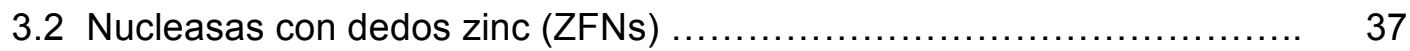

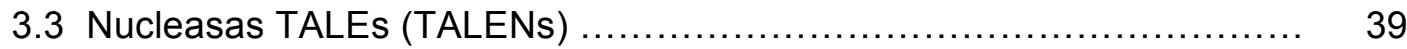

3.4 Endonucleasa de DNA dependiente de RNA Cas9 del sistema

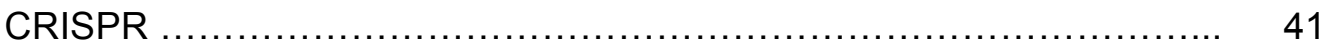

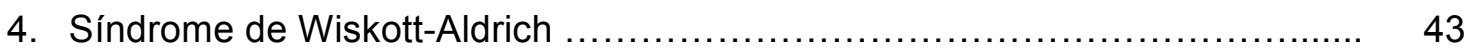

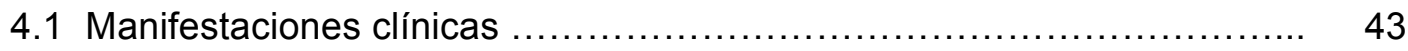

4.2 Mecanismos moleculares del síndrome de Wiskott-Aldrich ............... 45

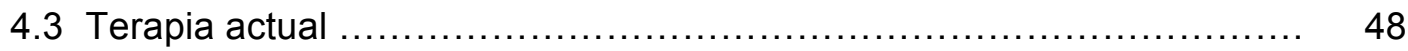

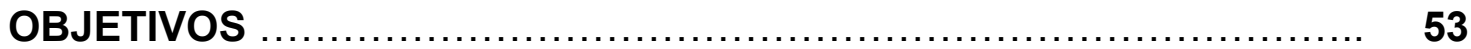

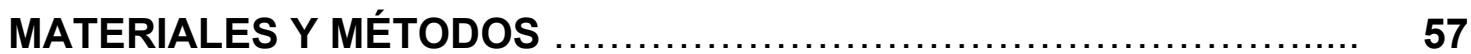

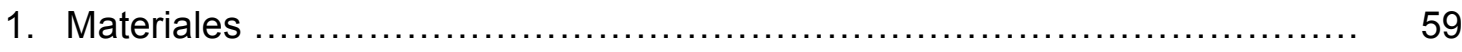

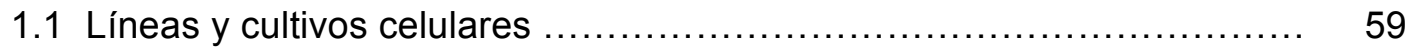

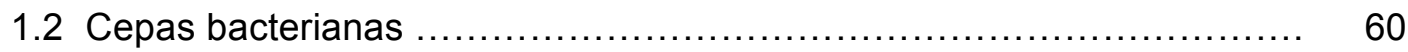

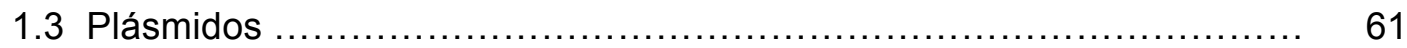

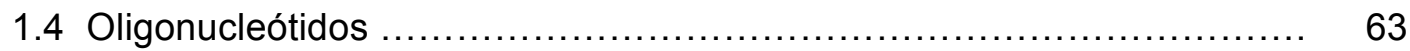

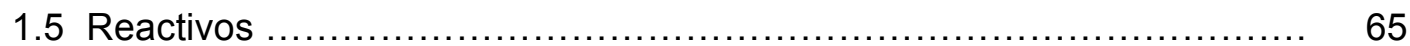




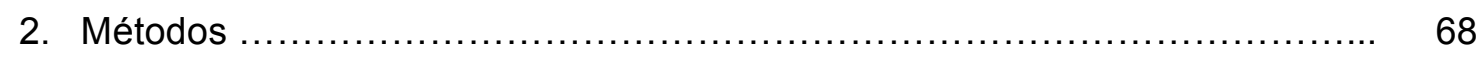

2.1 Técnicas básicas de Biología Molecular ............................. 68

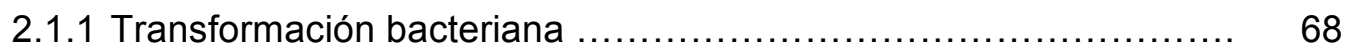

2.1.2 Purificación de plásmidos a pequeña escala (minipreps) ............ 68

2.1.3 Purificación de plásmidos a mediana escala (midipreps) ............ 69

2.1 .4 Ligación ...................................................... 70

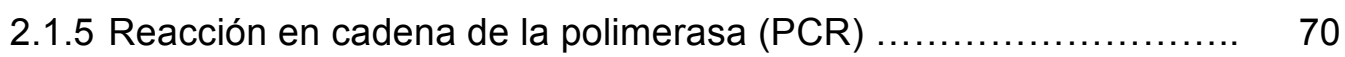

2.1.6 Extracción de DNA a partir de un cultivo celular ................... 70

2.1.7 Electroforesis en gel de poliacrilamida (SDS-PAGE) .............. 71

2.1.8 Tinción de geles de poliacrilamida con azul de Coomassie .......... 71

2.1.9 Western Blot ..................................................... 71

2.2 Generación de proteínas de fusión. Cre recombinasa y ScRad52 …..... 72

2.2.1 Diseño y construcción de un plásmido de expresión bacteriana para la proteína recombinante Cre recombinasa ................ 73

2.2.2 Diseño y construcción de un plásmido de expresión bacteriana para la proteína recombinante ScRad52 ….................... 74

2.2.3 Expresión y purificación de Cre recombinasa y ScRad52 …........ 74

2.2.4 SDS-PAGE y Western Blot ................................ 76

2.3 Línea célula reportera HCT116-RCL .................................. 76

2.3.1 Diseño y construcción de un vector reportero MCS- $\Delta 3$-EGFPtrunc-vector ...................................... 76

2.3.2 Diseño y construcción de un vector donante

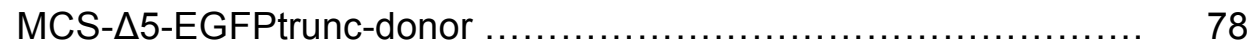

2.3.3 Generación de una línea celular reportera .......................... 79

2.3.4 Obtención del virus adenoasociado AAV- $\triangle 5$-EGFPtrunc-donor .... 80

2.3.5 Cuantificación del título adenoviral ............................... 82

2.3.6 Diseño y construcción de TALENs ................................ 83

2.3.7 Funcionalidad in vitro de las TALENs en la RCL ................... 86

2.3.8 ScRad52. Cambios en la frecuencia de recombinación homóloga... 87

2.3.9 Librería de siRNAs. Cambios en la frecuencia de

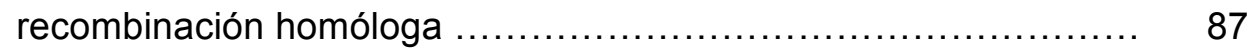

2.4 Generación, corrección y transdiferenciación de la línea celular WASP-KO

2.4.1 Diseño y construcción del vector pAAV-WASP-KO mediante

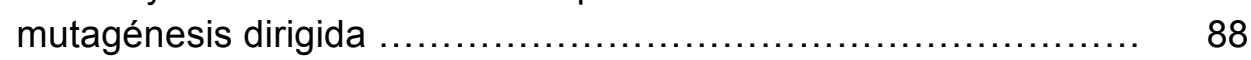

2.4.2 Construcción del vector pAAV-WASP-wt ....................... 90 
2.4.3 Construcción de los virus AAV-WASP-KO y AAV-WASP-wt ......... 90

2.4.3 Diseño y construcción de nickasas CRISPR/Cas9 para WASP ...... 91

2.4.4 Generación de líneas celulares WASP-KO ........................ 92

2.4.5 Tratamiento de células $\mathrm{KO}$ con Cre recombinasa .................. 93

2.4.6 Corrección de la línea celular WASP-KO .......................... 94

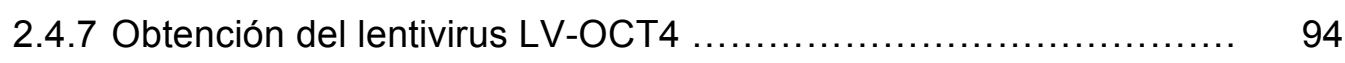

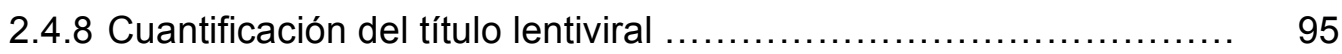

2.4.9 Conversión de fibroblastos corregidos a células hematopoyéticas.. 96

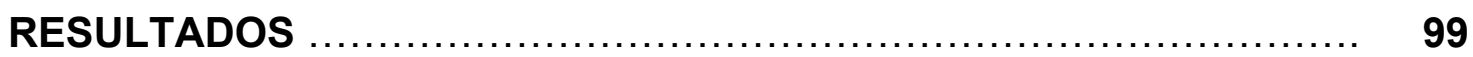

1. Generación de una línea celular reportera ................................ 101

2. Obtención y cuantificación del rAAV donante: AAV-A5-EGFP-donor........... 103

3. Transducción de la línea celular reportera con el virus donante AAV- $\Delta 5$ -

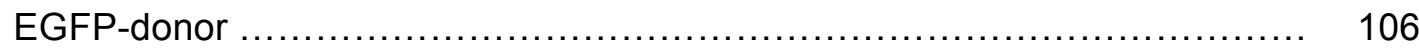

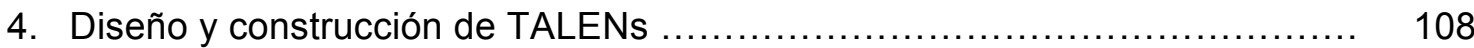

5. Funcionalidad in vitro de las TALENs en la HCT116-RCL .................... 111

6. ScRad52. Cambios en la frecuencia de recombinación homóloga ............ 112

7. Librería de siRNAs. Cambios en la frecuencia de recombinación homóloga .. 114

8. Generación, corrección y transdiferenciación de la línea celular WASP-KO .. 122

8.1 Diseño y construcción de los vectores p-AAV-MCS-WASP-KO y

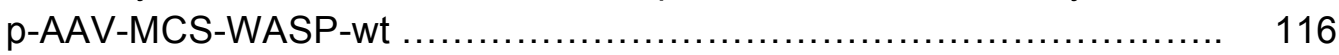

8.2 Construcción de los virus AAV-WASP-KO y AAV-WASP-wt ............... 124

8.3 Diseño y construcción de nickasas CRISPR/Cas9 para WASP ........... 125

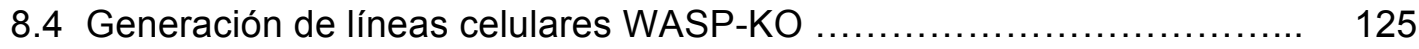

8.5 Tratamiento de la línea celular WASP-KO con CRE recombinasa y posterior corrección de la misma ................................... 128

8.6 Obtención y cuantificación del lentivirus LV-Oct4 ...................... 130

8.7 Transdiferenciación de fibroblastos a células hematopoyéticas ........... 130

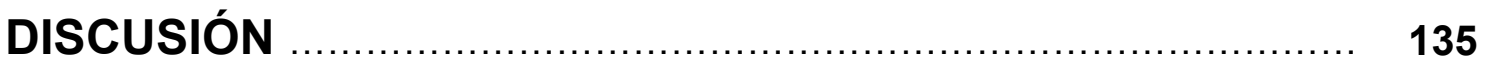

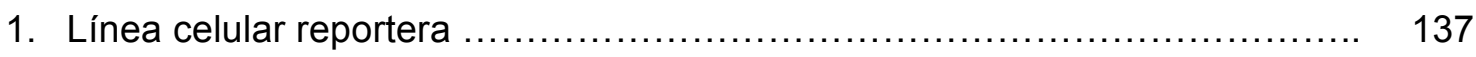

2. Cambios en la frecuencia de recombinación homóloga ..................... 141

3. Generación y corrección de líneas celulares WASP-KO $\ldots \ldots \ldots \ldots \ldots \ldots \ldots \ldots \ldots \ldots \ldots \ldots$

4. Transdiferenciación de fibroblastos corregidos a células hematopoyéticas ... 154

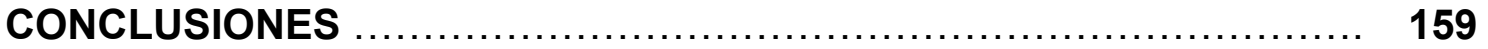

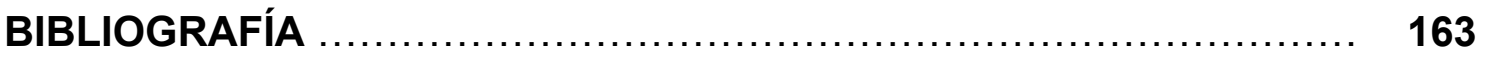




\section{ANEXOS}

1. Mapas de plásmidos comerciales utilizados .................................... 181

2. Librería de siRNAs. Características de cada siRNA …......................... 184

3. Datos estadísticos obtenidos en los diferentes experimentos realizados ...... 191

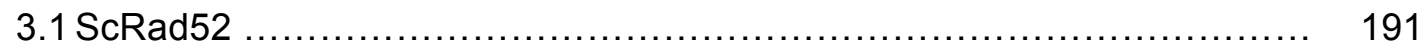

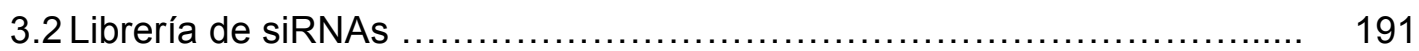

3.3 SiRNAs de comprobación ................................................. 194

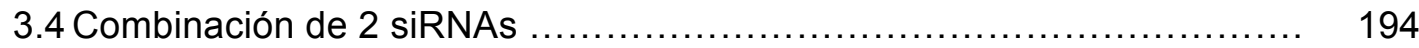

3.5 Combinación de 3 siRNAs ................................................ 195

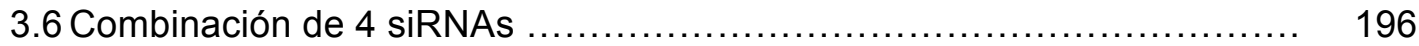




\section{ABREVIATURAS.}

"La ciencia es como la tierra, solo se puede poseer un poco de ella"

Voltaire (1694 - 1778) 

$\alpha$ : anti.

$\gamma$ RVs: Vectores $\gamma$-retrovirales ( $\gamma$-retroviral vectors).

AR: Región acida (acidic region).

ATCC: La ATCC es una organización privada sin ánimo de lucro en el campo de la biotecnología cuya misión consiste en la adquisición, autentificación, producción, preservación desarrollo y distribución de microrganismos de referencia, líneas celulares y otros materiales para investigación en ciencias de la salud (American type culture collection).

AAV: Virus adenoasociados (adeno-associated virus).

AAV2: Virus adenoasociados serotipo 2 (adeno-associated virus serotype 2).

AAVS1: Sitio de inserción de virus adenoasociados en el cromosoma 19.

Arm: Brazo de homología.

ATG: Codón de inicio de la traducción que codifica para el aminoácido metionina.

BBL1: Plásmido de nivel 1 para la construcción de TALENs (backbone level 1).

BBL2: Plásmido de nivel 2 para la construcción de TALENs (backbone level 2).

bFGF: Factor de crecimiento de fibroblastos (basic fibroblast growth factor).

bp: Par de bases (base pair).

BR: Región básica (basic region)

Cas9: Proteína asociada a CRISPR con función nucleasa (CRISPR associated protein).

CD45: Proteína tirosina fosfatasa que en encuentra en las células hematopoyéticas, principalmente en linfocitos (cluster of differentiation 45).

cDNA: DNA copia obtenido a partir de mRNA (complementary DNA).

CME: Célula madre embrionaria.

CMH: Célula madre hematopoyética.

CMV: Promotor del citomegalovirus.

CRE: Proteína con función recombinasa, proveniente del bacteriófago P1.

crRNA: CRISPR RNA.

CRISPR: Repeticiones palindrómicas cortas agrupadas y regularmente espaciadas (clustered regularly interspaced short palindromic repeats). 
DAPI: 4 ',6-diamino-2-fenilindol, colorante nuclear fosforescente (emite fluorescencia azul).

D.O.: Densidad óptica.

DNA: Ácido desoxirribonucleico (deoxyribonucleic acid).

DSB: Roturas de doble cadena en el DNA (double strand break).

dsDNA: DNA de doble cadena (double strand DNA).

dsRNA: RNA de doble cadena (double strand RNA).

EF1 $\alpha$ : Promotor para el factor de elongación $1 \alpha$ (elongation factor $1 \alpha)$.

EGFP: Proteína fluorescente verde aumentada (enhanced green fluorescent protein).

GFP: Proteína fluorescente verde (green fluorescent protein).

GT: Manipulación génica dirigida (gene targeting).

HBS: Tampón HEPES salino (HEPES buffer saline).

HEPES: ácido N-[2-hidroxietil]piperazin-N'-[2-etanolsulfónico].

His: Histidina.

HSA: Albúmina humana (human serum albumin).

hRad52: Proteína humana Rad52.

IGFII: Factor de crecimiento insulínico tipo 2 (insulin-like growth factor 2).

IgG: Inmunoglobulina G.

IIt3L: Ligando del factor de transcripción similar a inmunoglobulina tipo 3 (immunoglobulin-like transcript 3 ligand).

iPSC: Célula madre pluripotente inducida (induced pluripotent stem cell).

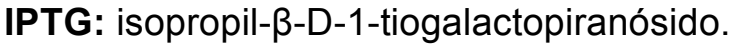

IRES: Sitio de entrada al ribosoma (internal ribosome entry site).

ITR: Repeticiones terminales invertidas (inverted terminal repeats).

$\mathbf{K b}$ : kilobases.

KO: knockout.

LB: Medio líquido de cultivo bacteriano Luria-Bertani.

LoxP: Sitio que recombina mediante la acción de la proteína Cre recombinasa, en orden de eliminar el segmento génico situado entre dos de estos sitios. 
LTRs: Repeticiones terminales largas (long terminal repeats).

LVs: Lentivirus.

MCS: Sitio de clonación múltiple (multiple cloning site).

MOI: Multiplicidad de infección, número de genomas virales que infecta una célula (multiplicity of infection).

mRNA: RNA mensajero (messenger RNA).

NEAA: Aminoácidos no esenciales (non essential aminoacids).

NHEJ: Recombinación no-homóloga (non homologous end joining).

NLS: Señal de localización nuclear (nuclear localization signal).

ORF: Marco de lectura abierta (open reading frames).

PCR: Reacción en cadena de la polimerasa (polymerase chain reaction).

PH: Dominio de homología a pleckstrina (pleckstrin homology).

PICs: Complejos de pre-integración (pre-integration complexes).

PolyA: Señal de poliadenilación, mediante la cual se añade una cola de polyA al mRNA naciente.

PTD: Dominio de transducción de proteína (protein transduction domain).

PVDF: Fluoruro de polivinilideno (polyvinylidene fluoride).

rAAV: Virus adenoasociado recombinante (recombinant adeno-associated virus).

RCL: Línea celular reportera (reporter cell line).

Rev: Proteína del virus de la inmunodeficiencia humana que se une al elemento de respuesta $(R R E)$, para facilitar su transporte al núcleo.

RH: Recombinación homóloga (homologous recombination).

RISC: Complejo de silenciamiento inducido por RNA (RNA-induced silencing complex).

RNA: Ácido Ribonucleico (ribonucleic acid).

RNAi: RNA de interferencia (RNA interference).

RPA: Proteína de replicación A (replication protein A).

RRE: Elemento de respuesta a Rev, secuencia a la cual se une la proteína Rev (rev responsive element). 
RT-pPCR: PCR cuantitativa en tiempo real (quantitative real time PCR).

SAP: fosfatasa alcalina de camarones (shrimp alkaline phosphatase).

SBF: Suero bovino fetal.

SCF: Factor de células madres (stem cell factor).

ScRad52: Proteína Rad52 de S. cerevisiae.

SDS-PAGE: Electroforesis en gel de poliacrilamida en presencia de SDS.

shRNA: Pequeña horquilla de RNA (small hairpin RNA).

SIN: Vectores auto-inactivables para la transcripción (self-inactivating).

siRNA: RNA pequeño de interferencia (small interfering RNA).

ssDNA: DNA de simple cadena (single strand DNA).

SNC: Sistema nervioso central.

TALENs o nucleasas TALEs: activador de la transcripción similar a nucleasa efectora (transcription activator-like effector nuclease).

TAR: Secuencia diana para la transactivación lentiviral, a la cual se une TAT.

TAT: Transactivador de la transcripción genética (trans-activator of transcription).

tracrRNA: crRNA trans-activador.

U3: Región en el extremo 3' del genoma viral (RNA) que contiene las secuencias necesarias para la activación de la transcripción.

VIH: Virus de la inmunodeficiencia humana (Human immunodeficiency virus).

VSV-G: glicoproteína del virus de estomatitis vesicular, que confiere de amplio tropismo a la cápside lentiviral (glycoprotein of the vesicular stomatitis virus).

WAS: Gen del síndrome de Wiskott-Aldrich (Wiskott-Aldrich syndrome gene).

WAS: Síndrome de Wiskott-Aldrich (Wiskott-Aldrich syndrome).

WASp: Proteína del Sindrome de Wiskott-Aldrich (Wiskott-Aldrich syndrome protein).

WIP: Proteína de interacción con WASp (WASp interacting protein).

WPRE: elemento regulador postranscripcional del virus de la hepatitis de marmota (Woodchuck hepatitis virus postranscriptional regulatory element).

XLT: trombocitopenia ligada al cromosoma X (X-linked thrombocytopenia).

ZFNs: Nucleasas con dedos de zinc (zinc finger nucleases). 


\section{RESUMEN。}

"Intenta no volverte un hombre de éxito, sino volverte un hombre de valor"

Albert Einstein (1879 - 1955) 
La modificación génica dirigida es un proceso mediante el cual, un gen defectuoso es sustituido por uno normal, lo que requiere la participación de la maquinaria celular de reparación mediante recombinación homóloga $(\mathrm{RH})$. La $\mathrm{RH}$ es un mecanismo que en células de mamíferos ocurre a muy baja frecuencia, motivo por el cual nos hemos planteado estudiar diferentes condiciones experimentales que mejoren dicha frecuencia.

Como método de estudio de frecuencia de $\mathrm{RH}$, se generó una línea celular reportera HCT116-RCL, en la que se introdujo una copia del gen EGFP truncado en el extremo 3' (no funcional). En paralelo, se generó un virus adenoasociado recombinante (rAAV), AAV- $\triangle 5$-EGFP-donor, que contenía el gen EGFP truncado en el extremo $5^{\prime}$. Mediante la utilización de esta línea celular y del rAAV y de una pareja de nucleasas TALEs, se estudió una proteína de fusión ScRad52 y una librería de 84 siRNAs dirigidos frente a genes implicados en la vía de recombinación no homóloga (NHEJ), así como frente a otros de funciones diferentes. También se llevaron a cabo tratamientos combinados de algunos siRNAs, para estudiar un posible efecto sinérgico en las mezclas. Se observó que, tanto ScRad52, como 12 de estos siRNAs, y algunas de las combinaciones fueron capaces de incrementar significativamente la frecuencia de $\mathrm{RH}$ en la célula reportera, sin alterar la viabilidad de manera significativa.

Una vez determinadas las mejores condiciones para poder aumentar la frecuencia de $\mathrm{RH}$, estas condiciones se aplicaron para la generación de una línea celular knock out para el gen WAS (Wiskott-Aldrich Syndrome) en fibroblastos primarios. Para ello se generó un rAAV que contenía la mutación en WAS que se quería introducir en el genoma celular. Estos fibroblastos $\mathrm{KO}$, se asemejan a los fibroblastos de pacientes enfermos de Síndrome de Wiskott-Aldrich (WAS). WAS es una inmunodeficiencia primaria severa de herencia recesiva, ligada al cromosoma $\mathrm{X}$, caracterizada por la presencia de infecciones recurrentes, eczema y trombocitopenia. Es así que, una vez obtenida la célula $\mathrm{KO}$, se procedió a la corrección de la mutación en dichas células, esta vez, utilizando un rAAV que contenía una copia wild type del gen. En paralelo, se construyó una línea $\mathrm{KO}$ en la línea celular T Jurkat utilizando el sistema de nickasas CRISPR/Cas9.

Finalmente, los fibroblastos primarios cuya mutación fue corregida, y que por lo tanto, contienen una copia normal del gen WAS se transdiferenciaron eficientemente a células progenitoras hematopoyéticas (CD45+), comprobándose la expresión normal de la proteína WASp. 
Hoy en día están llevándose a cabo diferentes protocolos de terapia génica en pacientes con diversas patologías. Dichos protocolos están basados en la adición del gen normal, que es deficiente en el paciente.

Somos conscientes que, aunque la corrección génica dirigida sobre la que trata el presente trabajo de tesis doctoral, sería un método más seguro, quedan todavía muchos problemas que resolver para que esta nueva tecnología pueda ser aplicada en la práctica clínica. Es por ello, de mucho interés, seguir investigando nuevos métodos de inducción de $\mathrm{RH}$ y nuevos reactivos que puedan potenciar la modificación génica. Con la irrupción de sistemas sencillos y versátiles, como es el caso de las CRISPR/Cas9, y los continuos avances en la mejora de las frecuencias de RH conseguidas, se está avanzando a gran velocidad. Sin embargo, es importante generar aún más conocimiento sobre los mecanismos y sistemas de transferencia de los diversos reactivos a células o tejidos específicos que hagan suficientemente eficaz la expresión de los genes deseados en las células a tratar. 


\section{INTRODUCCIÓN.}

"La ciencia es, respecto del alma, lo que es la luz respecto de los ojos, y si las raíces son amargas, los frutos son muy dulces" Aristóteles (384 AC- 322 AC) 


\section{TERAPIA GÉNICA}

\subsection{Definición y clasificación.}

La terapia génica puede definirse como el conjunto de técnicas que permiten vehiculizar secuencias de DNA o RNA hacia el interior de células diana, con el objeto de regular la expresión de una proteína en concreto, la cual interviene en una determinada enfermedad.

En función del tipo de células que se utilicen como diana, la terapia génica puede llevarse a cabo en células germinales o en células somáticas. En las primeras, las modificaciones génicas realizadas serán transmitidas a la descendencia. Si bien esta sería la forma más eficaz de corregir enfermedades de tipo congénito, de manera definitiva, aún no se ha encontrado una forma segura y eficaz de desarrollarla. En cuanto a las modificaciones realizadas en las células somáticas, éstas podrán ser beneficiosas para el paciente, pero no serán transmitidas a la descendencia; y es la terapia que actualmente está desarrollándose para ciertas enfermedades. Sin embargo, en ambos casos, es de vital importancia considerar los aspectos éticos que involucran a la terapia génica.

Otra manera de clasificar a los métodos de terapia génica, es según la estrategia que se aplique para llevarla a cabo. Dentro de esta clasificación tenemos, la terapia génica in vivo, donde se introduce el material genético de manera directa en el organismo, sin recibir ninguna manipulación in vitro; y la terapia génica ex vivo, dónde se extraen células del paciente, a las cuales se les realiza una transferencia de material genético in vitro, y luego se vuelven a introducir al paciente. Este último caso, tiene la ventaja de que las células que se introducen al paciente son previamente seleccionadas y, por tanto, son aquellas en las que se ha realizado una transferencia génica exitosa y de bajo riesgo para el paciente (Lazo, 1996).

Una tercera clasificación se da según la manera en que actúa el material genético exógeno al ingresar en la célula diana. En este caso podemos tener:

- Terapia génica aditiva, donde se introduce una versión normal del gen defectuoso, sin modificar el gen endógeno. Este procedimiento se realiza con el fin de expresar la proteína deficiente en el paciente, la cual debe alcanzar los niveles necesarios en el tejido específico, para alcanzar a revertir el fenotipo en la enfermedad presentada por dicho paciente. La terapia suele realizarse utilizando un vector viral que se integre en el genoma y, de este modo, pueda expresarse la proteína a largo plazo. Este procedimiento, suele introducir una copia del gen de manera aleatoria en el genoma, aunque también puede dirigirse la inserción del mismo a una localización preseleccionada dentro del genoma. 
- Modificación génica dirigida, donde el gen defectuoso es sustituido por uno normal, lo que requiere la participación de la maquinaria de la reparación mediante recombinación homóloga $(\mathrm{RH})$.

- $\quad$ Supresión génica, donde el gen defectuoso es eliminado totalmente (modelo knockout), o bien, su expresión es reducida (modelo knockdown). La supresión génica puede ser utilizada en enfermedades donde existe sobreexpresión de cierta proteína, como ocurre en algunos tipos de cáncer.

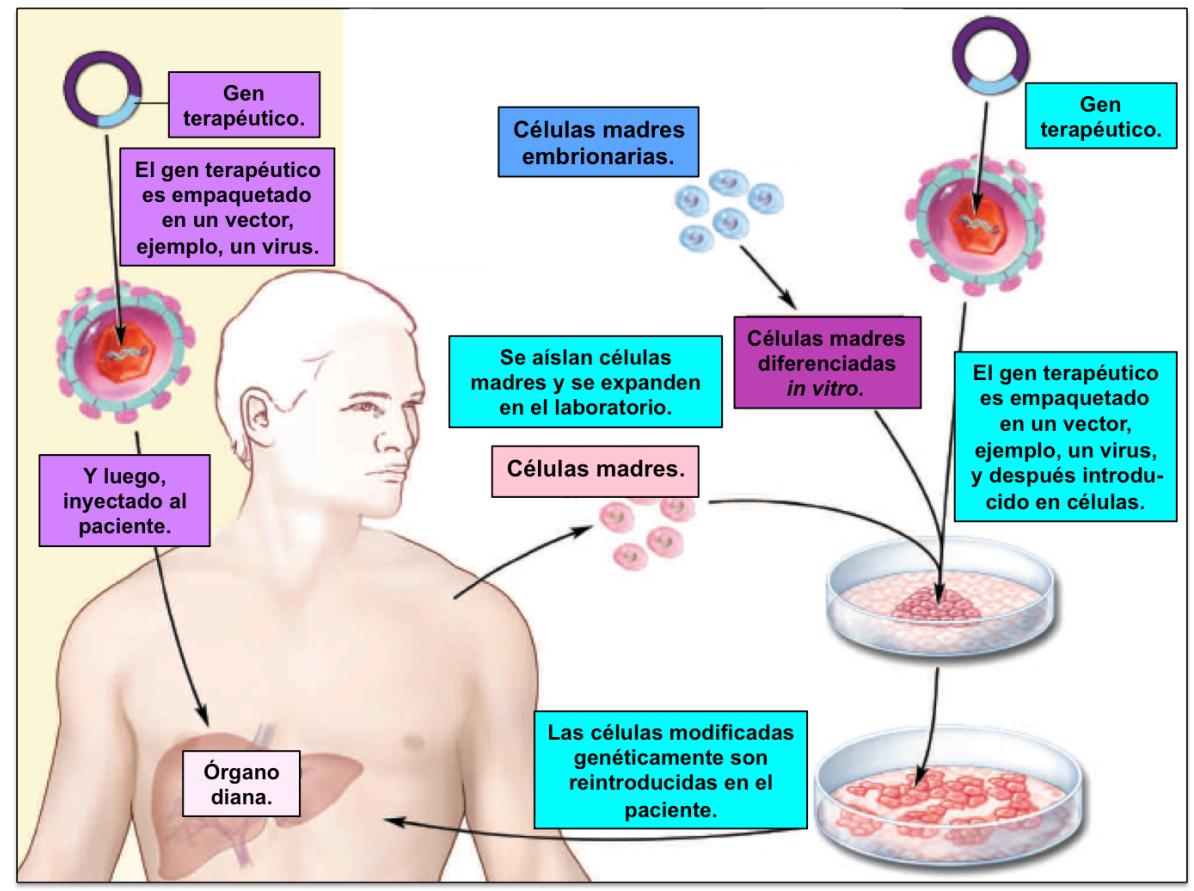

Figura 1. Terapia génica. Esta puede ser llevada a cabo in vivo, dónde se añade un vector que contiene el transgén directamente en el paciente. O puede realizarse ex vivo, donde se extraen células madre autólogas, que son modificadas genéticamente y se vuelven a introducir al paciente. Imagen tomada y modificada de Wislow T, 2006.

\subsection{Terapia génica en enfermedades monogénicas.}

Las enfermedades hereditarias monogénicas son aquellas producidas por alteraciones en la secuencia del DNA de un solo gen; comprenden numerosas enfermedades, muy diferentes unas de otras. En ellas, la falta de una proteína funcional o su expresión alterada o la aparición de un producto aberrante, conducen al paciente a manifestar los signos y/o síntomas correspondientes a la enfermedad que causa dicho gen defectuoso. La posibilidad de administrar al paciente la proteína deficiente, de manera efectiva, se ve condicionada por diversos factores como la naturaleza de la proteína, en primer lugar, y luego la necesidad de que ésta llegue al sitio diana para realizar su acción. Es así, que son pocas las enfermedades genéticas en las cuales es factible administrar la proteína, y muchas las enfermedades en las que las terapias 
convencionales no funcionan, y es por esto que se debe recurrir a terapias alternativas, como es el caso de la terapia génica (Noell et al., 1998).

Estos inconvenientes podrían resolverse de forma más simple si, en lugar de suministrar la proteína, se insertara una copia normal del gen causante de la enfermedad, con lo cual se produciría la proteína de manera normal. Esto se ve simplificado ya que, en muchos casos, existe un número limitado de tejidos en los que se expresa el gen en cuestión y, por tanto, sólo se necesitaría introducir la copia normal del gen en dichos tejidos y no en todas las células del organismo. En cualquier caso, si además, se pudiera mantener la expresión de dicho gen de manera constante, la enfermedad podría ser curada o, al menos, paliada.

\subsection{Criterios para seleccionar una enfermedad monogénica como candidata para recibir terapia génica.}

Los criterios para seleccionar una enfermedad monogénica como candidata para recibir terapia génica fueron definidos por Gamundi en 2002 y constan de los siguientes ítems:

- La enfermedad ha de amenazar gravemente la vida del paciente;

- Debe conocerse con precisión que órganos, tejidos y tipos celulares están afectados por la enfermedad;

- La versión normal del gen defectuoso debe haber sido aislada y clonada;

- El gen normal ha de poder ser introducido en una fracción significativa de células del tejido afectado, o bien la introducción del gen en un tejido accesible, puede beneficiar directamente el curso de la enfermedad en el tejido afectado;

- El gen debe poderse expresar adecuadamente, generando una cantidad suficiente de proteína normal

\subsection{Mecanismos de reparación del DNA y su intervención en los procedimientos de manipulación génica dirigida.}

Las rupturas de la doble cadena de DNA (DSB, double-strand break) pueden ser causadas por factores endógenos o exógenos. Naturalmente, las DSBs pueden ser generadas de manera espontánea durante la síntesis del DNA cuando la horquilla de replicación se encuentra con un DNA molde dañado y, también, durante procesos celulares específicos, como la recombinación $V(D) J$ que ocurre en las cadenas pesadas de las inmunoglobulinas, o como en la meiosis. Factores externos como la 
exposición a radiaciones ionizantes (rayos $\mathrm{X}$ y rayos $\gamma$ ), luz UV, inhibidores de la topoisomerasa, drogas radiomiméticas o bien nucleasas diseñadas específicamente para este fin también pueden producir DSBs y otros tipos de daños en el DNA. Cuando las reparaciones de las DSBs no se llevan a cabo, ocurren problemas graves entre los que se encuentran translocaciones y deleciones, la muerte celular o mutaciones que llevan al desarrollo de cáncer (Hartlerode et al., 2009). Los procesos de reparación de las DSBs pueden llevarse a cabo por dos vías principales (figura 2): la vía de la recombinación no homóloga (NHEJ, non-homologous end-joining) y la vía de la recombinación homóloga $(\mathrm{RH})$.

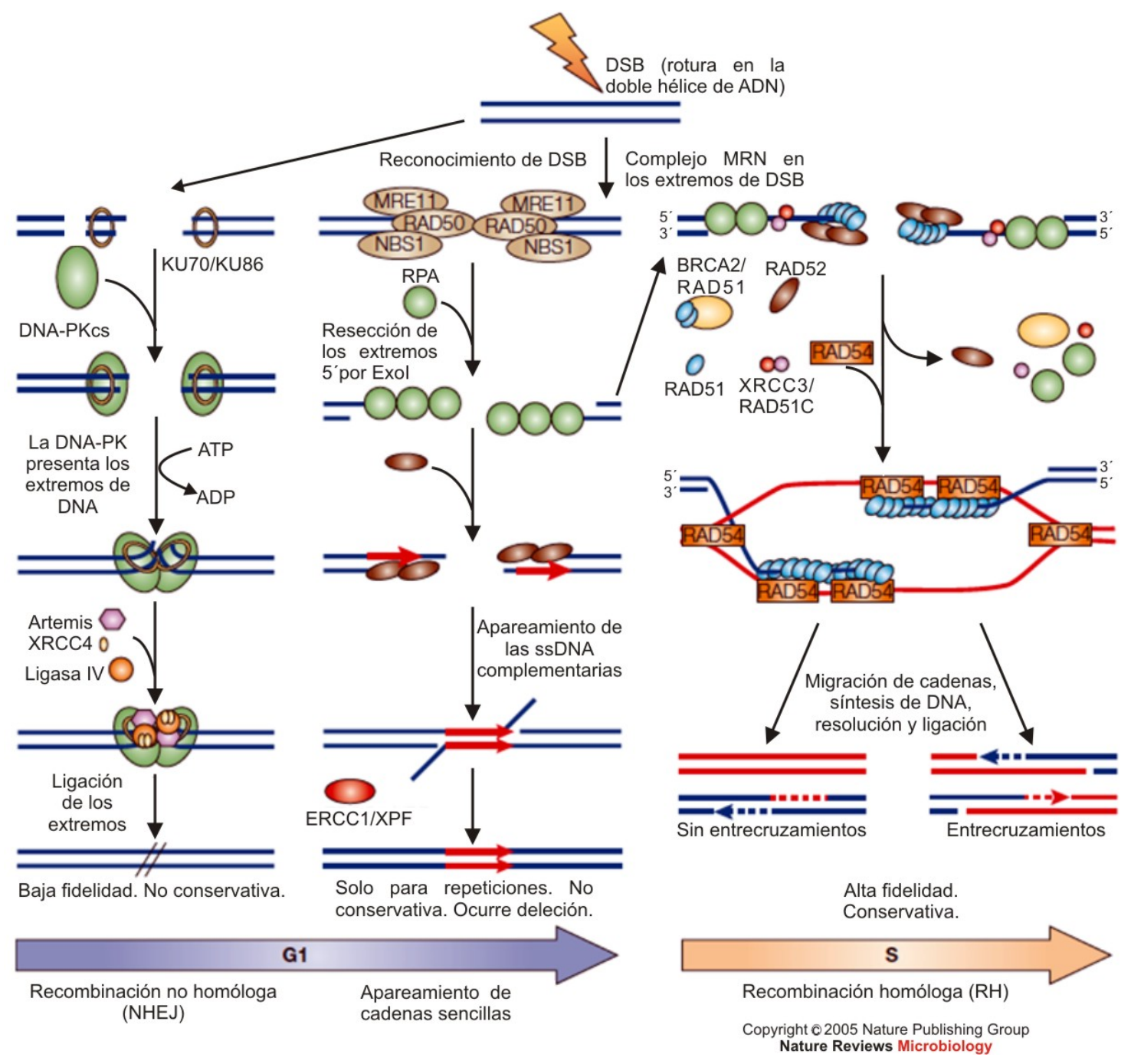

Figura 2. Vías de reparación de DSBs, y proteínas que intervienen en dichas vías. En la figura se observan las dos vías principales: la vía no homóloga (NHEJ) y la vía homóloga $(\mathrm{RH})$, junto con un tercer mecanismo, la vía de apareamiento de cadenas sencillas. Imagen tomada y modificada de Vasileva et al., 2005.

La NHEJ es un mecanismo fisiológico eficiente de reparación, y representa la vía de reparación predominante en mamíferos, ocurriendo en una relación de 1000:1 con respecto a la $\mathrm{RH}$ (Fattah et al., 2008). Las proteínas principales que intervienen en la 
NHEJ se encuentran altamente conservadas. Durante la NHEJ, los extremos del DNA que ha sufrido una DSB son reconocidos, capturados y atraídos por el complejo Ku70Ku80 (también llamado complejo Ku), al cual se une con alta afinidad. El complejo Ku es capaz de reclutar otras proteínas como: a) DNA-PKcs (subunidad catalítica de la proteína quinasa dependiente de DNA, del inglés, DNA-dependent protein kinase catalytic subunit) codificada en humanos por el gen PRKDC. Esta tiene actividad serina/treonina quinasa sólo cuando forma complejo con $\mathrm{Ku}$; b) Artemis, proteína codificada en humanos por el gen DCLRE1C (DNA cross-link repair), es una proteína con actividad exonucleasa $5^{\prime} \rightarrow 3^{\prime}$, sólo cuando forma un complejo con la DNA-PKcs; c) otras proteínas asociadas entre las que destaca el complejo XRCC4-DNA ligasa IV, que interactúa de manera estable con el complejo DNA-Ku y permite, de esta manera, la ligación entre los extremos. En resumen, después de la formación sucesiva de los anteriores complejos proteicos, los extremos del DNA son procesados y finalmente ligados, completándose así la reparación mediante NHEJ. La NHEJ es un sistema muy eficiente de reparación de DNA pero su naturaleza imprecisa puede causar pequeñas inserciones y deleciones. Esta vía es activa durante todo el ciclo celular, pero lo es más aún durante las fases del ciclo celular G0, G1 y $S$ temprana (figura 3).

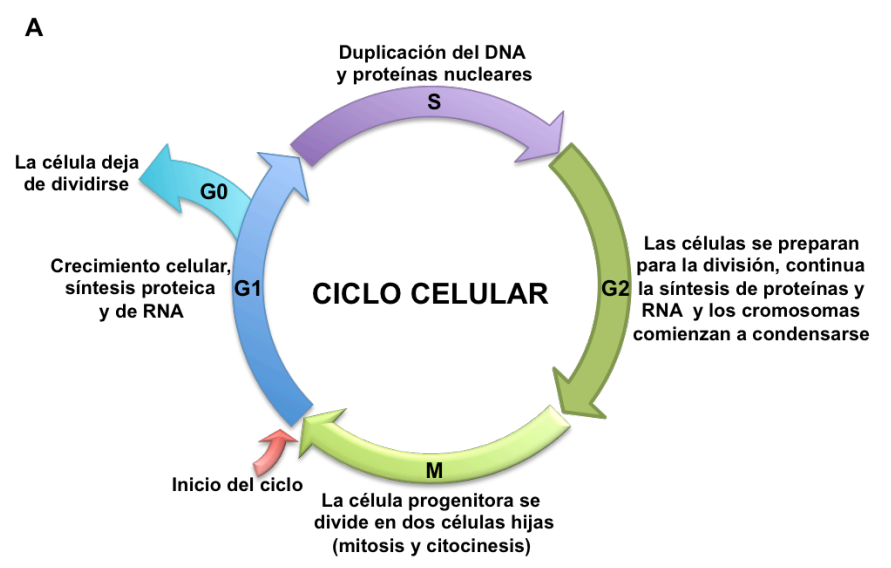

B

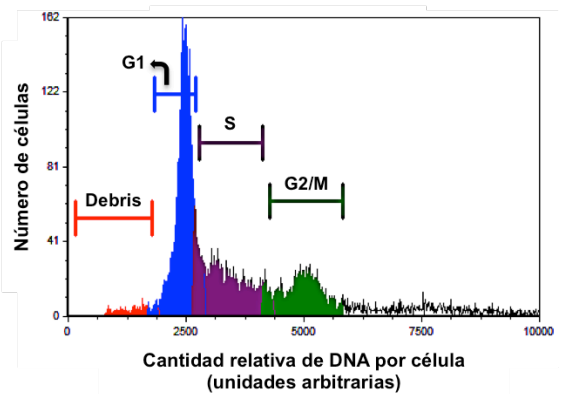

Figura 3. Ciclo celular. A. Representación esquemática de las fases del ciclo celular. B. Análisis del contenido de DNA en las diferentes fases del ciclo mediante tinción con yoduro de propidio y citometría de flujo. En azul se observa el pico correspondiente a las células en fase G1, en morado las células en S y en verde las que se encuentran en G2/M. Esta última imagen fue tomada y modificada a partir de denovosoftware.com.

La RH se encuentra, generalmente, restringida a la fase $S$ tardía y a $\mathrm{G} 2$ (figura 3), ya que normalmente utiliza la cromátida hermana intacta como DNA molde para la reparación. La RH se inicia cuando el complejo Mre11-Rad50-Nbs1/Xrs2 (también llamado complejo MRN) reconoce los extremos generados durante la DSB y se une a ellos, seguido por la unión del cofactor CtPI, lo cual termina por producir la resección de los extremos en sentido $5^{\prime} \rightarrow 3^{\prime}$, por parte de la exonucleasa humana I (hExol), para producir los extremos $3^{\prime}$ libres de cadena sencilla (ssDNA, single strand DNA). La 
proteína de replicación A (RPA, replication protein A) se une al extremo 3' ssDNA generado durante la resección, antes de que Rad51 comience la búsqueda de homología. En levaduras, Rad52 cataliza la unión de Rad51 con el ssDNA, sin la intervención de RPA (Symington, 2002). El filamento así formado, y recubierto por Rad51 comienza la búsqueda de homología y cataliza el intercambio de cadenas para permitir, así, la reparación de la DSB. La RH está considerada como un mecanismo libre de errores, ya que utiliza principalmente la presencia de una secuencia homóloga para producir reparación. A pesar de todo ello, en células de mamíferos las reparaciones se realizan mayoritariamente por NHEJ (Langerak et al., 2011. Shrivastav et al., 2008.).

Actualmente existen evidencias de que la manipulación del equilibrio entre NHEJ y RH (con inhibición de la primera y potenciación de la segunda) mediante diferentes sistemas puede incrementar la frecuencia de RH. Está muy bien demostrado que los cambios de expresión de las proteínas Ku pueden modificar la frecuencia de $\mathrm{RH}$ en diferentes hongos: por ejemplo, la deleción de Ku70 y Ku86 en Neurospora crassa resulta en un aumento de 5 veces en la frecuencia de RH (Ninomiya et al., 2004). En humanos, la disminución de los niveles de Ku70 en líneas HCT116 hemicigotas para Ku70 (Ku70 +/-) resultó en una frecuencia de RH 5 a 10 veces más alta que en células normales. El mismo efecto se confirmó mediante inhibición transitoria por RNAs pequeños de interferencia (siRNAs, small intereference RNAs), y de forma estable, mediante la expresión de RNAs horquillados cortos (shRNAs, short hairpin RNAs) (Fattah et al., 2008). Otro grupo ha corroborado estos hallazgos demostrando que el knockdown de Ku70 y Xrcc4 por siRNA en células humanas HCT116 produce un aumento de 30 veces en la frecuencia de RH del locus HPRT (Bertolini et al., 2009). Por otro lado, también se ha intentado promover el aumento en la frecuencia de $\mathrm{RH}$ mediante la sobreexpresión de proteínas clave en dicha vía. Así se ha comprobado que la expresión forzada de RAD51 aumenta a más del doble la frecuencia de RH en células HT1080 en dos loci diferentes, HRPT y 6-16 (Yáñez et al., 1999). También se observó un aumento de RH de más de 30 veces en células HeLa que sobreexpresan Rad52 de Saccharomyces cerevisiae, en relación a células control (Di Primio et al., 2005). Además, ciertos compuestos químicos han demostrado producir cambios en la frecuencia de $\mathrm{RH}$; mediante el rastreo de una librería de 10.000 compuestos se encontró uno conocido como RS-1 ((3-[(benzylamino)sulfonyl]-4-bromo-N-(4 bromophenyl)benzamide) que induce un cambio alostérico en el filamento de RAD51 y aumenta la recombinación homóloga en fibroblastos humanos sin efectos nocivos para la viabilidad celular (Jayathilaka et al., 2008). En conclusión, hay amplia 
documentación en la literatura demostrando potenciación de $\mathrm{RH}$ en células humanas mediante el uso de diferentes métodos.

\section{Mecanismos de transferencia génica.}

\subsection{Una visión general.}

Para realizar una transferencia génica con elevada eficiencia, es importante contar con un sistema de vehiculización o transferencia adecuado. Para ello, son utilizados vectores que introducen el material genético exógeno en las células diana. Estos vectores pueden ser virus modificados (vectores virales) o pueden ser formulaciones fisicoquímicas (vectores no virales). Las propiedades de un vector ideal pueden variar en función de las necesidades concretas pero, en cualquier caso, condicionarán enormemente el éxito del proceso. Actualmente no se dispone del vector ideal que pueda ser tan versátil como para adaptarse a las numerosas situaciones tanto clínicas como experimentales, sin embargo, existe un amplio abanico de vectores que pueden ser utilizados en transferencia génica.

Existen numerosos métodos de transferencia génica no virales, basados en métodos químicos y métodos físicos, que permiten transferir moléculas de gran tamaño, ya que en estos casos el DNA exógeno está integrado en un plásmido, que es el que se transfiere dentro de la célula diana. El problema que se presenta aquí, es la baja frecuencia de transferencia y la baja especificidad que tienen, como también que, con muchos de ellos, sólo pueden hacerse transferencias in vitro.

Por otro lado se encuentran los vectores virales, en los cuales se sustituyen los genes virales prescindibles por aquellos que se quieren introducir en las células dianas. Con excepción de los virus adenoasociados (AAV), que se integran específicamente en el cromosoma 19, y del Herpes Simplex Virus, que no se inserta en el genoma, los demás tienen la desventaja tanto de insertarse al azar en el genoma del huésped, como también la capacidad de insertar varias copias del mismo. A consecuencia de esto pueden aparecer mutaciones en el genoma que lleven a la transformación maligna de ciertas células o a la muerte celular. Otra de las desventajas que presentan estos vectores es la posibilidad de una respuesta inmune por parte del huésped, una vez realizada la terapia génica. Actualmente y a pesar de sus desventajas, los vectores virales constituyen la manera más eficaz de transferir genes terapéuticos en células dianas, y son los más utilizados en terapia génica. 
Una vez llevada a cabo la transferencia, el material genético puede integrarse en el genoma huésped o puede permanecer como material extracromosómico, formando los llamados episomas.

Los genes que se integran en el genoma, tienen la ventaja de transmitirse a la siguiente generación en cada división celular, por lo que se obtiene una expresión estable a largo plazo. Aun así, la inserción dentro del genoma no garantiza el éxito de la terapia génica, ya que el material genético puede insertarse dentro de regiones muy condensadas, y terminar así por no expresarse; en otros casos, la integración puede ocurrir dentro de zonas que codifican para oncogenes o genes supresores de tumor, o incluso, en genes implicados en la apoptosis celular, lo que conlleva un riesgo genotóxico, que acabaría en un crecimiento anormal e incontrolado de células.

En el caso de los episomas, estos suelen tener la desventaja de no mantenerse a largo plazo, sobre todo en células con alta tasa división, aunque una expresión a largo plazo no es imprescindible en todos los casos, y entonces sí que tendrían utilidad (Novelli et al., 2002).

\subsection{Métodos virales de transferencia génica.}

\subsubsection{Los virus adenoasociados (AAV).}

Los virus adenoasociados (AAV) se encuentran actualmente entre los vectores virales más utilizados en terapia génica. Históricamente, los AAV no han sido de gran interés médico debido a que no se asocian con ninguna patología en humanos. De hecho, cerca del $80 \%$ de la población humana es seropositiva para el subtipo más común, el AAV2 (AAV serotipo 2). Pero debido a su persistencia en el genoma que infectan y a la gran cantidad de serotipos diferentes que se han descrito, es que el interés por su potencial en terapia génica ha ido en aumento (Daya et al., 2008).

Los virus adenoasociados son virus pequeños sin envoltura y contienen un genoma, de cadena de DNA sencilla y lineal. Pertenecen a la familia Parvoviridae y al género Dependovirus, debido a que la infección por AAV ocurre sólo en presencia de un virus helper, ya sea un adenovirus o un virus herpes. En ausencia de este virus helper, el AAV puede permanecer latente integrándose en el cromosoma 19 (Weitzman et al., 1994).

EI AAV2, virus que utilizaremos en los experimentos desarrollados en este trabajo, posee un genoma compuesto por una cadena sencilla de DNA de $4.7 \mathrm{~kb}$ y se caracteriza por poseer secuencias invertidas de $145 \mathrm{bp}$, denominadas repeticiones terminales invertidas o ITRs (figura 4). Los primeros 125 nucleótidos de cada una de 
las ITRs son palíndromos que se pliegan sobre sí mismos para maximizar el apareamiento de bases, y formar así, una estructura de horquilla en forma de T. Las restantes 20 bases, conocidas como la secuencia $D$, se mantienen sin aparearse. Las ITRs son importantes secuencias en cis para la biología del virus, ya que actúan como cebador para la síntesis de una segunda cadena de DNA durante el proceso de replicación, mediante la intervención de una DNA-polimerasa. Durante la síntesis del genoma viral, se forman dsDNA como intermediarios, los cuales son luego procesados resultando finalmente, un ssDNA que se utiliza para empaquetarse y otro dsDNA utilizada para la transcripción. Las ITRs son también esenciales para el empaquetamiento del genoma viral, su transcripción, su regulación negativa en condiciones adversas y su integración sitio-específica. Entre ambas ITRs se encuentra una secuencia que contiene dos secuencias codificantes (ORF, marco abierto de lectura, open reading frame): cap y rep.

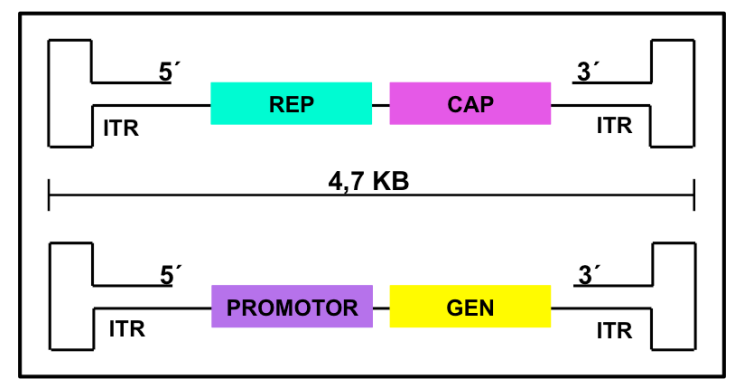

Figura 4: Esquema de un vector AAV. Arriba: Esquema del virus wt, con los genes REP y CAP. Abajo: Esquema del vector recombinante donde se han sustituido los genes originales por el transgén de interés.

El primer ORF contiene el gen Rep, el cual codifica cuatro proteínas: Rep78, Rep68, Rep52 y Rep40, que intervienen en la replicación del DNA. Rep78 y Rep68 son producidas a partir del mismo transcrito mediante la acción del promotor $\mathrm{P} 5$, siendo la primera la forma intacta (que no ha sufrido splicing) y siendo Rep68 la forma generada por splicing alternativo. Ambas son importantes proteínas reguladoras que actúan en trans en todas las fases del ciclo de vida del $A A V$, regulando la replicación $y$ transcripción de los genes del AAV. Asimismo, gracias a su actividad endonucleasa sitio-específica permite la integración del AAV en el genoma de la célula hospedadora en ausencia de virus helper. Por otro lado, las proteínas más pequeñas, Rep52 y Rep40 son producidas por medio del promotor P19, siendo la primera la forma intacta (que no ha sufrido splicing) y siendo Rep40 la forma generada por splicing alternativo. Estas dos proteínas están involucradas en la acumulación de ssDNA viral, utilizadas para empaquetarse junto con la cápside.

El segundo ORF, contiene el gen Cap que codifica tres proteínas de la cápside del virus: VP1, VP2 y VP3, mediante la acción del promotor P40. Las tres son sintetizadas 
a partir de dos transcritos, sufriendo diversos procesos de splicing alternativo. VP1 es obtenida a partir del transcrito que no ha sufrido splicing (87 kDa), la mayor de las proteínas de la cápside. Este transcrito sufre luego el proceso de splicing alternativo, mediante el cual se forman VP2 (72 kDa) y VP3 (62 kDa). La cápside de los AAV2 comprende 60 proteínas virales que forman una estructura icosaédrica (Daya et al., 2008).

Los virus $\mathrm{AAV}$, tienen dos sistemas de replicación, el ciclo lítico y el lisogénico. En presencia de un virus helper, predomina el ciclo lítico. Durante este período, el AAV lleva a cabo una infección productiva caracterizada por replicación del genoma, expresión de genes virales y producción de viriones. Los genes adenovirales que constituyen la función helper son, E1a, E1b, E2a, E4 y VA RNA. Mientras que los genes pertenecientes al herpes virus, expresan polimerasa y helicasas, así como también genes involucrados en la fase temprana de la transcripción. Aunque los genes provistos por ambos virus son diferentes, ambos regulan la expresión de genes de la célula proporcionando un medio intracelular permisivo, favorable para una infección productiva.

En ausencia de un virus helper, predomina el ciclo lisogénico. La replicación del AAV es limitada, la expresión génica es reprimida y el genoma puede entrar en una fase de latencia, mediante integración en una secuencia llamada AAVS1 localizada en el brazo largo del cromosoma 19 (19q13). El AAV se integra de manera que interrumpe la subunidad reguladora $12 \mathrm{C}$ del gen de una fosfatasa (PPP1R12C, también llamada MBS85). La función de la proteína codificada por este gen no ha sido todavía dilucidada, y por tanto, no se conocen efectos adversos que deriven de la perturbación del gen (Lombardo et al, 2011; Henckaerts et al., 2010). Esta región AAVS1, forma un complejo con AP1, una secuencia de unión a DNA que se encuentra en la horquilla del virus, es decir, en las ITRs (en cis), y junto con las proteínas Rep68 y Rep78 (en trans), ambas con actividad helicasa y endonucleasa, facilitan la recombinación que permite llevar a cabo de manera eficiente, la integración del virus al genoma del huésped (Weitzman et al., 1994). Se ha encontrado, además, que el genoma de los AAV2 se integra predominantemente como una copia única, y que la posibilidad de recombinación entre dos virus es muy baja, lo cual se convierte en una gran ventaja para una expresión estable a largo plazo sin que ocurra integración al azar, y con ello, mutagénesis insercional (Janovitz et al., 2014; Choi et al., 2014).

Sin embargo, en los vectores recombinantes ( $\mathrm{rAAV}$ ), derivados del virus wild-type, sólo se han mantenido las secuencias ITRs como únicas secuencias virales en el genoma (figura 4), y se han reemplazado las secuencias codificantes por un casete de expresión que contiene una determinada secuencia de interés (Basner-Tschakarjan et 
al., 2014). Debido a la deleción del gen Rep los rAAV pierden la capacidad de integrarse específicamente en el sitio AAVS1. Por ello, la persistencia del rAAV ha sido atribuida a la integración aleatoria o bien, a la formación de episomas. Se ha demostrado la existencia de genomas de rAAV circulares en músculo, y su persistencia episomal ha sido correlacionada con la expresión del transgén a largo plazo. Estos genomas circulares parecen originarse a través de una circularización monomérica, proceso que lleva a la formación de genomas circulares que se unen cabeza con cola. Sin embargo con el tiempo, disminuyen los monómeros circulares intermedios en favor de estructuras circulares de alto peso molecular, denominados concatémeros (Rohr et al., 2002).

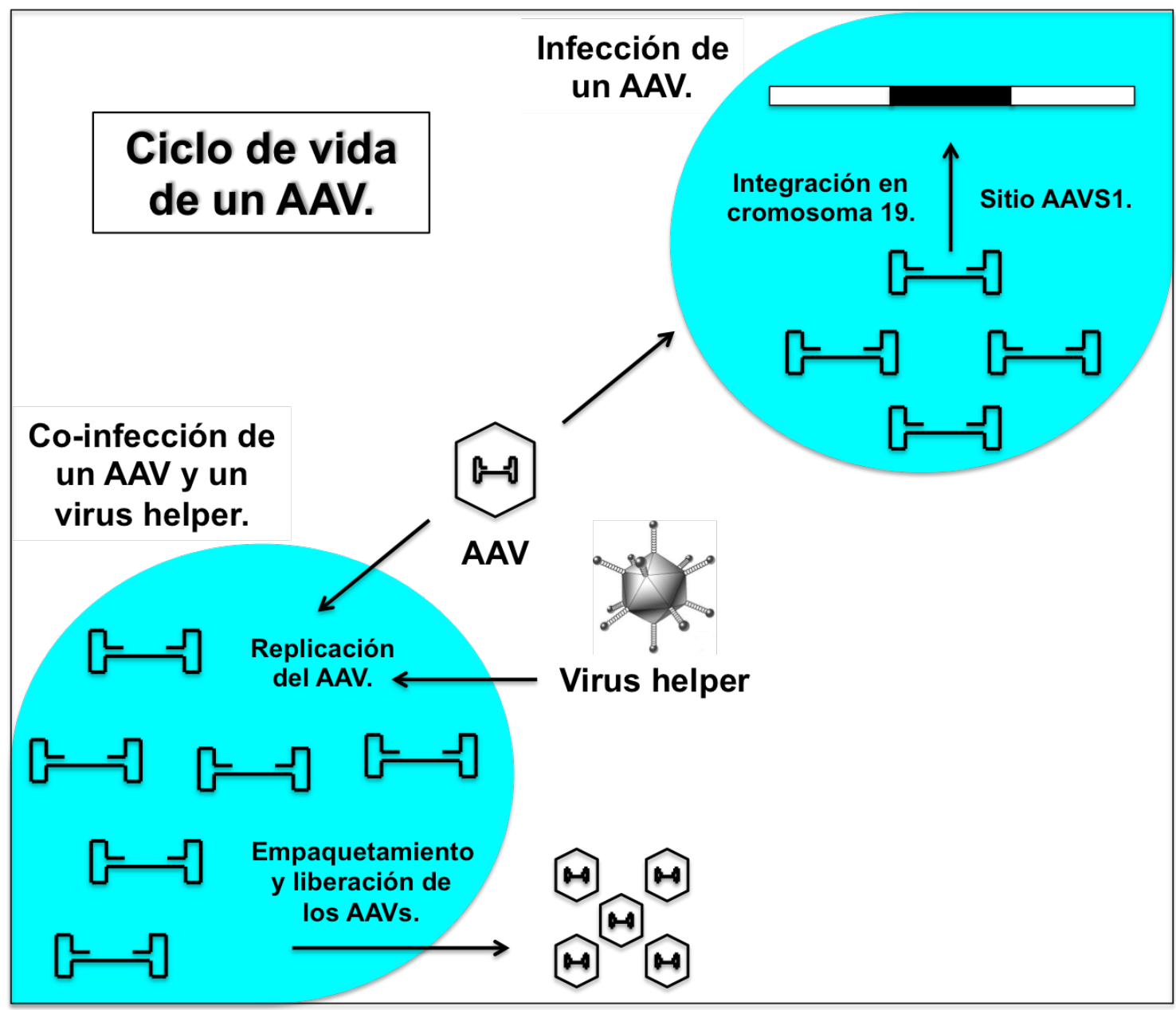

Figura 5: Ciclo de vida de un AAV wild-type. En presencia de un virus helper, el AAV se replica, empaqueta y libera de la célula hospedera. En cambio, si no hay co-infección, el AAV se integra en el cromosoma 19 (sitios AAVS1), donde permanece en estado de latencia. Imagen modificada a partir de Daya et al., 2008.

Los rAAV pueden introducir cambios en secuencias definidas, con elevada fidelidad, por favorecer el mecanismo de $\mathrm{RH}$. Se cree, que las ITRs del virus recombinante actúan como DSB, para inducir respuestas de tipo de reparación del DNA. Una vez que el virus elimina la cápside viral, RPA se une a la cadena de ssDNA del rAAV, 
luego de lo cual el complejo BRCA2-RAD51 sustituye a RPA, y así iniciar la vía RH para producir la modificación en una de las cadenas del DNA (figura 6. Vasileva et al., 2005). Mutaciones puntuales, inserciones, deleciones e inserciones de marcadores de selección han sido introducidos en diversos tipos de células humanas. Así mismo, los rAAV han sido utilizados con gran eficacia para modificaciones génicas en células humanas tales como fibroblastos, queratinocitos, células madres pluripotentes inducidas, entre otras. Recientemente, estos vectores virales también se han utilizado para introducir nuevos epítopos en diferentes loci de en una amplia variedad de líneas celulares, permitiendo así el estudio de proteínas cuando son expresadas en su ubicación cromosómica original (Yang et al., 1999; Khan et al., 2011).

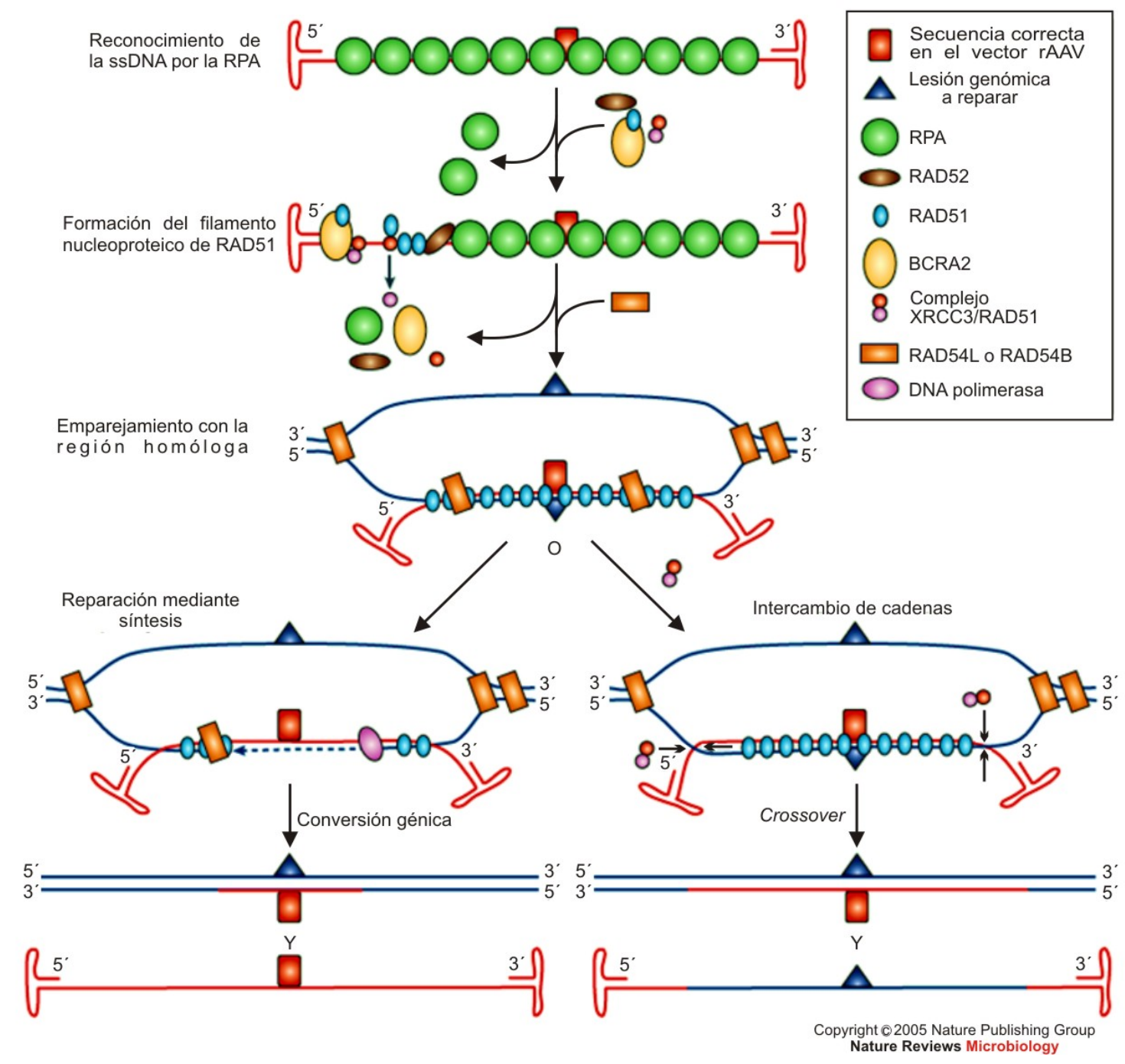

Figura 6: Mecanismos por los cuales, los vectores rAAVs son capaces de inducir modificación génica. Esta modificación génica dirigida se da mediante la vía de la $\mathrm{RH}$. En la imagen se observa el DNA genómico en azul y el genoma viral en rojo. Imagen tomada y modificada de Vasileva et al., 2005.

Según se ha mencionado de manera breve anteriormente, hoy en día se conoce la existencia de 11 serotipos diferentes de AAVs (Mori et al., 2004; Wu et al., 2006). 
Estos varían en la afinidad que cada uno de los serotipos tiene con un tejido específico del huésped, es decir, varían en el tropismo (Tabla 1).

\begin{tabular}{|c|c|}
\hline Serotipo & Tropismo \\
\hline AAV1 & Músculo esquelético, SNC. \\
\hline AAV2 & $\begin{array}{l}\text { Riñón, y con menor eficiencia de transducción, } \\
\text { hígado, músculo esquelético, pulmones y SNC }\end{array}$ \\
\hline AAV3 & Desconocido \\
\hline AAV4 & SNC (astrocitos), retina. \\
\hline AAV5 & SNC, células fotorreceptoras, retina. \\
\hline AAV6 & Músculo esquelético \\
\hline AAV7 & Músculo esquelético \\
\hline AAV8 & $\begin{array}{l}\text { Hígado, y con mayor eficiencia que los otros } \\
\text { serotipos: músculo esquelético, páncreas y corazón. }\end{array}$ \\
\hline AAV9 & Hígado, músculo esquelético, pulmones. \\
\hline AAV10 & Músculo esquelético. \\
\hline AAV11 & Músculo esquelético. \\
\hline
\end{tabular}

Tabla 1. Tropismo de los diferentes serotipos de AAVs conocidos hasta el momento. En negrita se señalan aquellos tejidos de mayor tropismo para cada serotipo (Mori et al., 2004. Wu et al., 2006).

Hoy en día es factible producir rAAVS en los cuales se combinan diversos serotipos para formar una cápside compuesta por una mezcla de subunidades de los diferentes serotipos. Esto permite no sólo mejorar, por ejemplo, el tropismo, sino también adquirir nuevas propiedades, diferentes a los $\mathrm{AAVs}$ parentales, como por ejemplo, ser capaces de transducir células que ninguno de los AAVs parentales que conforman el nuevo AAV (AAV mosaico), son capaces de transducir por separado (Wu et al., 2006).

Estos diferentes serotipos de AAVs se han estado utilizando en diversos ensayos clínicos o pre-clínicos de terapia génica. Tal es el caso de la enfermedad de Canavan, una leucodistrofia causada por una mutación en el gen de la aspartoacilasa (ASPA), que provoca un defecto metabólico del sistema nervioso central, y más precisamente en oligodendrocitos. Esta fue la primera enfermedad del sistema nervioso central autorizada para ser tratada en un ensayo clínico de terapia génica con AAV. A pesar de no haber mostrado eficacia terapéutica, sí se ha comprobado la seguridad y 
tolerancia de los vectores rAAV2 utilizados, como así también, se demostró ausencia de inflamación y de respuesta inmune celular (Chtarto et al., 2013).

Actualmente existen varios ensayos clínicos y pre-clínicos en diferentes patologías, los cuales utilizan rAAVs, como por ejemplo, aquellos que afectan a la retina. En fase clínica se encuentra su uso para la amaurosis congénita de Leber (LCA2), asociada a una mutación en el gen RPE65, donde se utilizó un rAAV2 con una copia normal de dicho gen. Luego de 3 años de seguimiento no se encontraron efectos adversos o respuestas inmunes debido al tratamiento, a la vez que se demostró una mejora en la visión de los pacientes sometidos al tratamiento. Por otro lado, en los ensayos preclínicos llevados a cabo para la acromatopsia o monocromatismo, donde se ven afectadas las células fotorreceptoras de la retina sensibles al color los conos, se han utilizado rAAV de serotipos 5 y 8 en ratones y perros, encontrándose resultados satisfactorios en ambos casos (Boye et al., 2013).

En 2013, el primer protocolo de terapia génica ha sido aprobado para su comercialización. Este se comercializa con el nombre de Glybera, que está basado en la utilización de un vector adenoasociado recombinante, mediante el cual se puede reemplazar al gen responsable de la expresión de la lipoproteinlipasa, enzima deficiente en algunos pacientes con niveles extremadamente altos de triglicéridos en sangre, causante de pancreatitis. El vector recombinante producido en este caso, fue producido haciendo uso del gen Cap del AAV serotipo 1 y las ITRs del AAV serotipo 2, esto se debió a que la frecuencia de anticuerpos neutralizantes dirigidos contra el AAV1 es mucho menor que la observada para el AAV2, como así también que los vectores rAAV1 presentan una mejor eficiencia de transducción en músculo esquelético que los rAAV2 y esto es de vital importancia ya que la lipoproteinlipasa se expresa fisiológicamente en dicho tejido (Bryant et al., 2013).

Estos resultados son muy prometedores, sin embargo, aún queda mucho por investigar para poder solucionar los inconvenientes encontrados en cuanto al tropismo y a las altas dosis necesarias para poder llevar a cabo una terapia génica. Debido a esto es que han estado desarrollándose diversas modificaciones para evitar estos inconvenientes. Por ejemplo, sabiendo que uno de los pasos más importantes para la expresión del transgén es la conversión del DNA de cadena sencilla (ssDNA) en DNA de doble cadena (dsDNA), se desarrollaron los AAV auto-complementarios (scAAV, del inglés, self-complementary AAV). Es así que, la necesidad de convertir el ssDNA en dsDNA se puede evitar mediante el empaquetamiento de dos cadenas como una sola molécula. Esto se logra mediante el aprovechamiento de la tendencia a producir dobles cadenas durante el ciclo de replicación de los AAVs. Si estos dímeros son lo suficientemente pequeños, tal que pueden empaquetarse de la misma manera que los 
AAVs normales, las dos mitades de la molécula de ssDNA podrán doblarse y generar un apareamiento de bases con la consecuente formación de dsDNA de la mitad de tamaño. Aunque esto restringe la capacidad del transgén a insertar, ofrece una mejora en la eficiencia y en la velocidad de expresión del transgén, ya que la conversión de dsDNA es independiente de la síntesis de DNA de la célula huésped y de la concentración del vector (McCarty, 2008). Este vector ha sido utilizado en ensayos clínicos de terapia génica en pacientes con hemofilia $B$. La decisión de utilizar este vector se debió a que en ensayos clínicos previos se observó que en la terapia con un rAAV2 clásico solo hubo expresión transitoria del transgén, lo que pudo haberse debido a una respuesta citotóxica por parte de las células $T$ en contra de los hepatocitos transducidos con el virus. Para sobrellevar esta cuestión, se utilizó un AAV8 con especial tropismo por células hepáticas, y que además, presenta una muy baja frecuencia de anticuerpos neutralizantes, en comparación con el AAV2 Nathwani et al., 2011).

Otra de las modificaciones realizadas para mejorar la eficiencia de estos virus, fue la mutación de las tirosinas expuestas en la superficie de la cápside del AAV2 (Y444 e Y730). Mediante esta modificación se logra evitar parcialmente el proceso de ubiquitinación impidiendo, así, la degradación por parte del proteasoma lo cual resulta en un importante aumento en la eficiencia de transducción a menores dosis (Zhong et al., 2008).

Finalmente, se ha creado una variante nueva de rAAVs a través de ingeniería genética de las proteínas de la cápside habiéndose generado secuencias mixtas que se obtuvieron de varios de los serotipos ya conocidos. Se seleccionaron las combinaciones que conferían un tropismo mayor para células hepáticas y se comprobó que el nuevo virus transducia con más eficiencia muchos otros tipos celulares. El nuevo rAAV se conoce con el nombre de AAV-DJ (Lerch TF., 2012).

\subsubsection{Los lentivirus (LV).}

Los lentivirus, son virus pertenecientes a la familia Retroviridae, subfamilia Lentivirinae. Estos virus presentan un genoma constituido por RNA, pero se replican por medio de un DNA intermediario, haciendo uso de la enzima transcriptasa inversa. El nombre de esta subfamilia alude al largo período de incubación que transcurre entre la infección y la enfermedad, que puede incluso superar los 10 años. Dentro de esta subfamilia se encuentra, por ejemplo, el virus del VIH (virus de la inmunodeficiencia humana). Los virus de la familia Retroviridae, se caracterizan, también, por ser 
partículas envueltas de $80-120 \mathrm{~nm}$, que contienen nucleocápside enrollada dentro de una cubierta icosaédrica (Cordeiro et al., 2006).

Los LVs constan de tres genes esenciales, gag, pol y env, además de dos regiones no codificantes que los flanquean, llamadas repeticiones terminales largas, LTRs (long terminal repeats), idénticas entre sí (Belshaw et al., 2004). El gen gag codifica para proteínas de la cápside, pol codifica para enzimas que intervienen en la transcripción inversa y env codifica para proteínas de la envoltura.

La integración del cDNA viral en el genoma de la célula huésped es un paso esencial dentro del ciclo de vida de los retrovirus. Una vez que el virus ha entrado en la célula, la transcriptasa inversa codificada por el gen lentiviral pol, utiliza el genoma viral (RNA) como molde para la síntesis de una doble cadena de DNA complementaria; además, esta enzima tiene actividad RNAsa, mediante la cual se destruye el molde luego de ser copiado. Una vez sintetizada la doble cadena de DNA, es luego ensamblado para formar los complejos de pre-integración (PICs, pre-integration complexes), los cuales contienen proteínas virales y proteínas celulares. Los PICs pueden entrar activamente en el núcleo de células que no se dividen, como es el caso de los LVs, o pueden lograr el acceso al DNA durante la mitosis, como en el caso de los restantes miembros de la familia Retroviridae. Los PICs se asocian con la cromatina de la célula huésped, donde la integrasa codificada por el gen lentiviral pol media la inserción del genoma viral en el genoma hospedador. Inicialmente se creyó que, los vectores retrovirales se insertaban de manera completamente aleatoria en el genoma de la célula huésped a la que infectaban, sin embargo, hoy en día se conoce que la mayoría de ellos presentan una inserción semi aleatoria, influenciando así el destino de la célula transducida (Biasco et al., 2011). Así pues, estos virus se integran, preferentemente, en regiones de cromatina abierta, transcripcionalmente activas, como las islas CpG, donde la inserción de secuencias aumentadoras (enhancers) de las repeticiones terminales largas generan una alta probabilidad de interferir en la regulación génica (Felice et al., 2009).

Durante las últimas décadas, los vectores retrovirales, derivados del Virus de la Leucemia Murina de Moloney (Logan et al., 2002), han sido utilizados en ensayos clínicos en diferentes inmunodeficiencias primarias, creyéndose estos relativamente seguros. Sin embargo, una de las principales desventajas de estos vectores fue el uso de la región U3 del LTR viral para dirigir la expresión del transgén, la cual contiene potentes regiones promotoras y enhancers que son responsables de la activación de genes cercanos al sitio de integración. Se han descrito desórdenes linfoproliferativos en pacientes tratados por Inmunodeficiencia Combinada Severa Ligada al X (X-SCID, $X$-linked severe combined immunodeficiency. Hacein-Bey-Abina et al., 2003). Estos 
ensayos han servido para dejar en claro el alto potencial que posee la terapia génica, sin embargo, también han puesto de manifiesto el inconveniente de la mutagénesis insercional. En estos casos se han desarrollado leucemias y mielodisplasias debido a la activación de oncogenes, por lo cual se ha vuelto cada vez más importante la monitorización del perfil insercional de estos vectores (Biasco et al., 2011).

Debido a los inconvenientes hasta aquí mencionados, se comenzaron a utilizar vectores lentivirales basados en el virus de la inmunodeficiencia humana $1(\mathrm{VIH}-1)$, ya que estos no tienen la tendencia a integrarse en zonas transcripcionalmente activas lo que conlleva un menor riesgo de mutagénesis insercional y que resulta en una expresión del transgén a largo plazo, a la vez que ofrecen otras ventajas, entre las se encuentran, la posibilidad de infectar diferentes tipos celulares (células quiescentes, de división lenta, o células que no se dividen), su gran capacidad de empaquetamiento, y la escasa respuesta inmune que induce su integración (Quinonez et al., 2002).

En las primeras generaciones de estos vectores se incluían todos los genes necesarios que codifican las diversas partículas virales, excepto aquellas involucradas en la envoltura (Naldini et al, 1996). En la última generación de vectores VIH-1 todo el genoma viral ha sido delecionado y sólo contienen los LTRs imprescindibles para su integración en el genoma celular. Los genes lentivirales esenciales gag, pol y env, y los reguladores tat (que codificara proteínas que intervienen en la regulación de la transcripción) y rev (que codifica proteínas de exportación del mRNA al núcleo) se aportan en trans para la generación de virus recombinantes.

Para incrementar más aún la seguridad biológica de estos vectores se han desarrollado vectores auto-inactivables para la transcripción (SIN, self-inactivating) en los cuales la secuencia aumentadora (enhancer) y el promotor de la región U3 del LTR $3^{\prime}$ han sido eliminados. Esta modificación reduce la genotoxicidad derivada de la interferencia de promotores/enhancers virales. La región U3 ha sido sustituida por promotores alternativos como el promotor del CMV (Miyoshi et al., 1998) y el factor de elongación EF-1 $\alpha$ (Zychlinski et al., 2008) que dirigen la expresión del transgén y son menos capaces de activar genes vecinos de lo que pueden serlo los promotores virales. Las ventajas de estos LVs con LTRs auto-inactivables (SIN) han sido demostradas en diferentes estudios preclínicos para diferentes inmunodeficiencias primarias (Farinelli et al., 2013). 


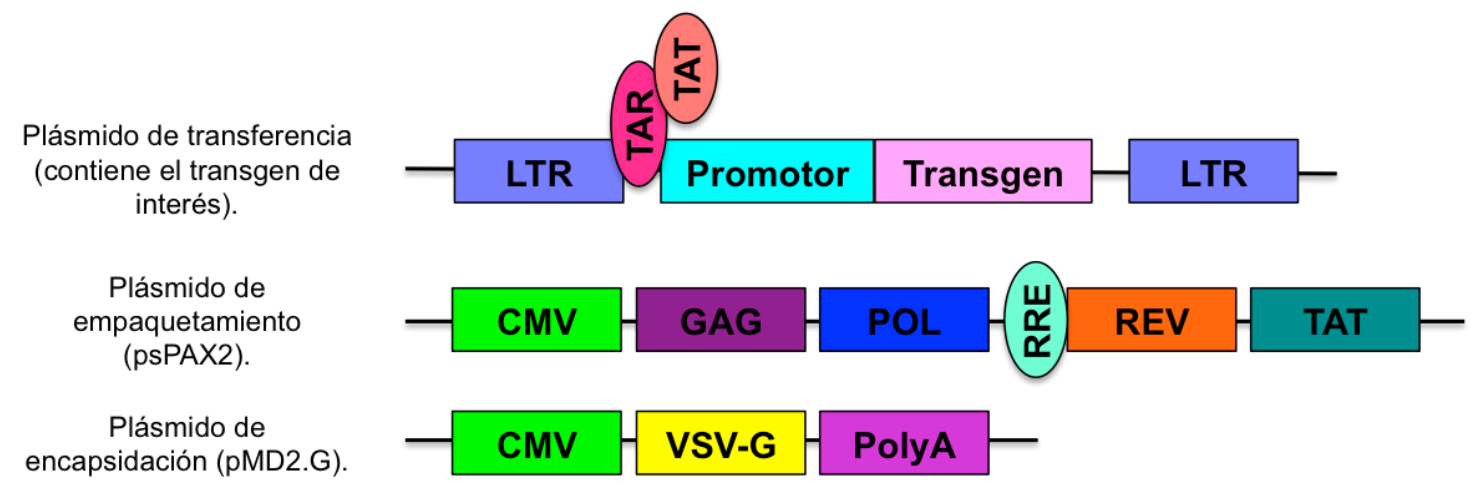

Figura 7. Lentivirus de segunda generación. Mapas de los 3 plásmidos utilizados para su construcción. Imagen tomada y modificada de addgene.com.

\section{Las nucleasas en ingeniería genética.}

\subsection{Características y aplicaciones.}

El procedimiento de manipulación génica dirigida se desarrolla a través del proceso de $\mathrm{RH}$, según el cual el vector, al encontrar su secuencia homóloga en el gen diana, induce la recombinación. Las ventajas de la manipulación génica dirigida, sobre los métodos que adicionan genes, son:

- $\quad$ Capacidad de modificar secuencias específicas;

- $\quad$ Preservación de la regulación transcripcional del gen;

- Disminución de los riesgos de mutagénesis insercional y de activación de oncogenes debido a integración aleatoria.

Sin embargo, este proceso de recombinación homóloga tiene un inconveniente, y es la baja frecuencia con la que ocurre en los mamíferos, particularmente en humanos (Vasileva et al., 2005). Con el fin de solucionar este inconveniente es que se descubrió que, la existencia de un DSB en un plásmido, producía RH entre este y el cromosoma cuya secuencia era homóloga a la del plásmido. Sin embargo, durante este proceso, sólo el plásmido era modificado, debido a que era quien contenía las rupturas en ambas cadenas (Jasin et al., 1985). Esto llevó a creer que esta misma estrategia podría ser utilizada en ingeniería genética, modificando el cromosoma en estudio, en lugar de un plásmido. Es así que nacieron las primeras herramientas diseñadas para modificar un locus endógeno en mamíferos (Jasin et al., 2013)

Dentro de las herramientas desarrolladas, y más utilizadas para aumentar la frecuencia de $\mathrm{RH}$, se encuentran aquellas basados en nucleasas quiméricas que están compuestas por secuencias de unión al DNA ligadas a un dominio nucleasa que escinde el DNA, generando, así, la ruptura del DNA. Las más empleadas son las ZNFs (zinc finger nucleases), TALENs (transcription activator-like effector nucleases) y 
CRISPR (clustered regularly interspaced short palindromic repeats). Estas nucleasas quiméricas permiten un amplio rango de modificaciones génicas induciendo cortes en el DNA, mediante lo cual se activa la maquinaria de reparación celular (Gaj et al., 2013).

Cuando las rupturas del DNA causadas por nucleasas, son reparadas por NHEJ, pueden generarse pequeñas inserciones o deleciones en el sitio diana, y con ello, producir el silenciamiento de un gen (Santiago et al., 2008). Asimismo, mediante la NHEJ, se pueden inducir deleciones más largas (Lee et al., 2010), inversiones (Lee et al., 2012), y translocaciones (Brunet et al., 2009), de grandes segmentos génicos. Por otro lado, la $\mathrm{RH}$ nos da la posibilidad de realizar deleciones e inserciones génicas, de manera dirigida, mediado por la acción de un DNA donante, homólogo al DNA a modificar.

\subsection{Nucleasas con dedos de zinc (ZFNs).}

Las ZFNs son proteínas artificiales que se generan mediante la fusión de varios dominios de dedos de zinc junto con el dominio catalítico de Fokl, una endonucleasa bacteriana de tipo IIS (con actividad endonucleasa y actividad metilasa, dadas por proteínas separadas que actúan de manera independiente) (Delacôte et al., 2011). Estos dominios están compuestos por un conjunto de 3-5 dedos de zinc (ZF). El dominio en ZF, uno de los dominios de unión al DNA más común en células humanas, está compuesto por unos 30 aminoácidos, formando una estructura en forma de loop o dedo que se mantiene unida gracias a la interacción de dos residuos cisteína y dos residuos histidina con un átomo central de Zinc (Cys2/His2). La función de estos dominios con dedos de Zinc se basa en la unión específica al DNA: cada dominio ZF reconoce un triplete de nucleótidos específico, por lo que la fusión de varios de estos dominios en una ZFN permite reconocer secuencias de DNA mayores. Como la nucleasa Fokl funciona como un dímero, una ZFN es funcional cuando se forma una pareja de ellas que estén posicionadas en estrecha proximidad y en orientaciones inversas (Sun et al., 2013).

Una vez que se ha generado la ruptura de la doble cadena de DNA, la célula pone en marcha sus mecanismos de reparación, la RH o bien la NHEJ. En el caso de existir un DNA donante homólogo, el mecanismo de preferencia para reparar el DSB será la RH (Moehle et al., 2007).

A pesar de que las ZFNs se han utilizado ampliamente para edición genómica, tienen dos importantes limitaciones. La primera de estas limitaciones es la complejidad de su construcción. Además, la falta de especificidad de algunos dominios ZF pueden 
generar cortes en localizaciones fuera de la diana (off target), dando lugar a mutaciones no deseadas y aberraciones cromosómicas (Pattanayak et al., 2011; Radecke et al., 2010).

La utilización de ZFNs validadas, como es el caso de la nucleasa comercial que corta el DNA en el cromosoma 19, y más exactamente en el sitio de inserción de los virus adenoasociados (AAVS1), permite la integración dirigida de manera muy eficiente. Mayor es aún la eficiencia, cuando las ZFNs son introducidas en células humanas junto con un DNA donante lo que favorece que el proceso de reparación del DNA ocurra a través de la recombinación homóloga. Así, la integración dirigida mediante ZFNs puede lograr una eficiencia del $20 \%$ en algunos tipos celulares (Lombardo et al., 2007), lo que representa un gran incremento en la eficiencia en eventos de recombinación homóloga normales en la mayoría de las células humanas ensayadas, que es 1 evento en $10^{6}$ (Bibikova et al., 2001).

En definitiva, la principal ventaja de utilizar las ZFNs reside en la capacidad de integración dirigida de un DNA exógeno, y con esto, la obtención de clones con una mínima variación en los niveles de expresión.

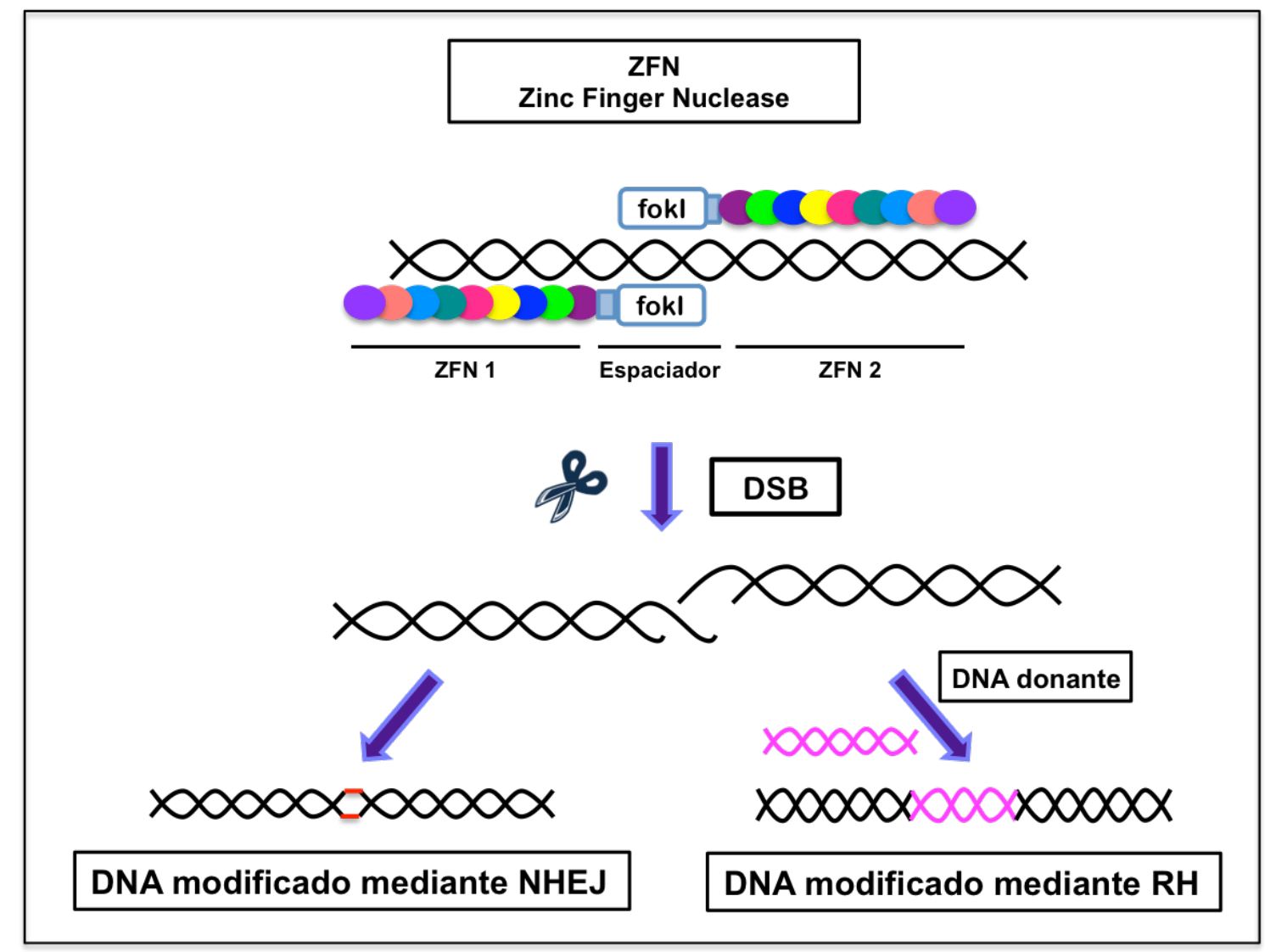

Figura 8. ZFN, nucleasas en dedos zinc. Generación de un corte en la doble cadena de DNA, y posterior reparación mediante NHEJ o RH. 


\subsection{Nucleasas TALE (TALENs).}

Las proteínas efectoras TALEs (transcription activator-like effectors) son secretadas por bacterias de la familia Xanthomonas, las cuales son capaces de penetrar en el núcleo de una célula vegetal, infectarla, y unirse a una secuencia de DNA genómico de manera específica, y regular así la expresión de los genes diana (Boch et al., 2010).

Recientemente, se ha visto que estas proteínas tienen una estructura modular, es decir, están compuestas por dominios homólogos repetidos, cada uno de ellos, de 3335 aminoácidos, de los cuales los residuos en las posiciones 12 y 13 (residuos variables) son los que le confieren a la proteína la especificidad de unirse a determinados nucleótidos (Moscou et al., 2009). La interacción entre la secuencia específica de DNA y las TALEs, se lleva a cabo entre el segundo residuo variable (posición 13) en cada repetición, y su correspondiente base en la cadena codificante del DNA (Sun et al., 2013).

Las nucleasas TALEN (Transcription activator-like effector nucleases) surgen de combinar un dominio N-terminal que incluye una señal de localización nuclear (NLS, nuclear localization signal), un dominio central compuesto de repeticiones en tándem de TALE que permiten el reconocimiento de secuencias específicas de DNA, y por último, un dominio C-terminal correspondiente al dominio nucleasa de Fokl. Esta endonucleasa funciona de forma dimérica, y por lo tanto, necesita de una pareja de TALENs para realizar un corte en un determinado sitio del genoma. La pareja de TALENs diseñadas se unen así a la secuencia diana, flanqueada por un DNA espaciador (normalmente entre 14 y $18 \mathrm{bp}$ ), que facilita la formación del dímero de Fokl. Es así como el dímero de Fokl corta en la región del DNA espaciador produciendo la ruptura de la doble cadena (Wei et al., 2013). Así, la ruptura generada en la doble hélice de DNA puede ser reparada mediante NHEJ, a no ser que exista un DNA homólogo que favorezca la reparación por $\mathrm{RH}$, introduciendo así las alteraciones deseadas en una secuencia de DNA diana (Jia et al., 2014).

Aunque el reconocimiento de una sola base en las repeticiones de las TALENs que se unen al DNA permite una mayor flexibilidad en su diseño, mayor que la que permiten las ZFNs al reconocer tripletes, la clonación de las repeticiones TALE presenta un desafío técnico elevado debido a las extensas secuencias repetidas e idénticas. Para superar este problema, se han desarrollado distintos métodos que permiten el ensamblaje rápido de las mismas. Dentro de estas técnicas se encuentran el clonado molecular mediante la técnica Golden Gate (Cermak et al., 2011), el ensamblaje mediante ligación rápida en plataforma sólida de alto rendimiento automatizada 
(FLASH, Fast Ligation-based Automatable Solid-phase High-throughput platform. Reyon et al., 2012), y por último, el ensamblaje mediante técnicas de clonación independientes de ligación (LIC, Ligation-independent cloning. Schmid-Burgk et al., 2013).

El Golden Gate es un método recientemente desarrollado para ensamblar múltiples fragmentos de DNA en forma ordenada en una sola reacción. Este método utiliza endonucleasas de restricción IIS, que cortan por fuera de su sitio de reconocimiento para crear extremos adhesivos de 4 bp únicos. La clonación se acelera mediante digestión y ligación en la misma mezcla de reacción. El correcto ensamblaje elimina el sitio de reconocimiento de la enzima (Cermak et al., 2011).

Para el método FLASH se cuenta con una colección de plásmidos que codifican para uno, dos, tres o cuatro repeticiones efectoras TAL que comprenden todas las posibles combinaciones de los pares de bases a ligar. El montaje automatizado se realizó mediante plataformas basadas en perlas magnéticas para ejecutar los pasos del protocolo: digestión, purificación y ligación (Reyon et al., 2012).

LIC es un método, que en sentido estricto, se refiere a un método que utiliza la T4 DNA polimerasa. En este método los diferentes fragmentos de DNA son tratados con la T4 DNA polimerasa para la generación de extremos monocatenarios protruyentes. Si se añade un dNTP a la mezcla de reacción, la actividad exonucleasa de la T4 compite por la actividad polimerasa exactamente hasta que hasta que las secuencias terminales de los fragmentos de dsDNA en la reacción, permiten la incorporación del dNTP suministrado (reacción de chewback). En sentido más amplio, LIC se refiere a un método de clonación en el que no intervienen procedimientos de ligación normales, si no que directamente se realiza la clonación después del chewback, sin necesidad de realizar ligaciones previas (Schmid-Burgk et al., 2013; Liu Y, 2013).

A pesar del éxito que han tenido las TALENs como herramientas edición génica, se ha observado que éstas han sido incapaces de cumplir su función en DNAs metilados, lo cual representa una desventaja importante para genes que se encuentran en la heterocromatina (Bultmann et al., 2012). 


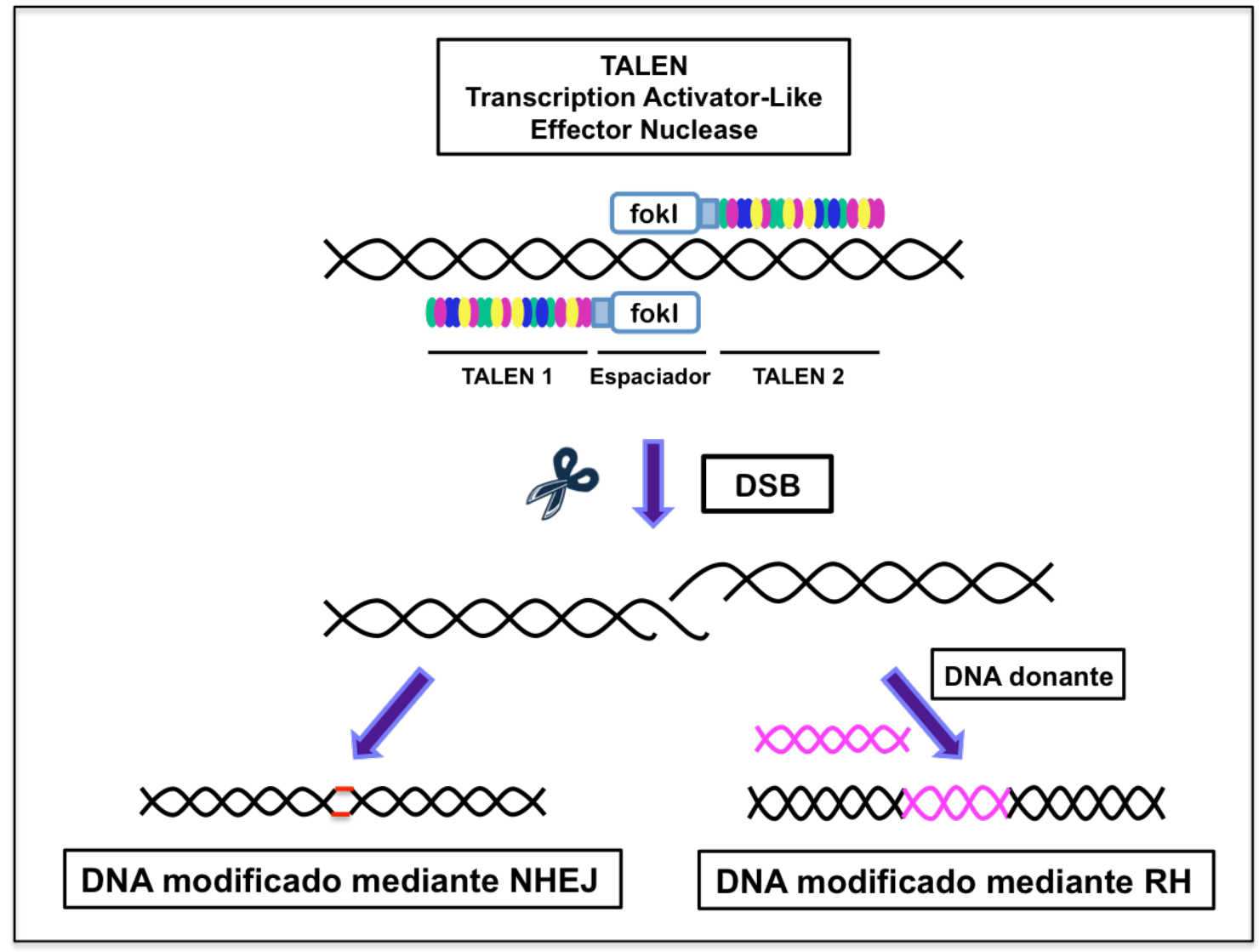

Figura 9. TALENs. Generación de un corte en la doble cadena de DNA, y posterior reparación mediante NHEJ o RH.

\subsection{Endonucleasas de DNA dependiente de RNA Cas9 del sistema CRISPR.}

El sistema de CRISPR/Cas9 ha surgido como una nueva herramienta de ingeniería genética, que representa un sistema fácil de diseñar, con una alta eficiencia (Ran et al., 2013).

El sistema CRISPR (repeticiones palindrómicas cortas agrupadas y regularmente espaciadas, del inglés Clustered regularly interspaced short palindromic repeats) / Cas (proteína asociada a CRISPR, del inglés CRISPR associated protein), constituye un sistema inmune adaptativo en bacterias el cual las provee de resistencia contra determinados virus y plásmidos, ya que resulta que los elementos espaciadores de las CRISPR contienen secuencias homólogas a elementos exógenos, incluidos entre ellos, bacteriófagos y plásmidos (Mojica et al., 2009).

Actualmente, existen diez sistemas CRISPR/Cas, que se diferencian por las secuencias CRISPR y los genes Cas que contienen, que codificarán para proteínas con diversas actividades bioquímicas. A su vez, estos diez sistemas se clasifican en tres categorías (Makarova et al., 2011). 
- Tipo I: contiene el gen cas3 que codifica para una proteína que presenta actividades helicasa y DNAsa, además de otros genes que codifican proteínas que forman parte de complejos multiproteicos con diferentes composiciones.

- $\quad$ Tipo II: se encuentra formado por la proteína multidominio Cas9, que presenta dos dominios con actividad nucleasa (el dominio nucleasa de tipo RuvC situado próximo al extremo $\mathrm{N}$-terminal, y el dominio de tipo $\mathrm{HNH}$ en el medio de la proteína). Esta proteína forma un complejo ternario con dos moléculas de RNA: crRNA (CRISPR RNA) y tracrRNA (transactivador de crRNA).

- Tipo III: este sistema puede dividirse en dos subtipos en función de los diferentes ácidos nucleicos a los que pueden ir dirigidos, pudiendo escindir plásmidos o RNA.

Sin embargo, aquí solo nos centraremos en el tipo II, es decir, el sistema formado por la proteína Cas9, que presenta dos dominios con actividad nucleasa, un dominio $\mathrm{N}$ terminal de tipo RuvC que corta la cadena $5^{\prime} \rightarrow 3^{\prime}$, también llamada cadena desplazada y un dominio $\mathrm{HNH}$, situado en mitad de la proteína y que corta la cadena $3^{\prime} \rightarrow 5^{\prime}$. En este sistema, el crRNA está formado por 42 nucleótidos, 20 de los cuales constituyen la secuencia conocida como espaciador, y otros 22 correspondientes a la secuencia repetida, y sirve como una secuencia específica que guía a la nucleasa Cas9 hacia el DNA diana, junto con el tracrRNA, que complementa parcialmente al crRNA, interviene en la maduración del crRNA y es necesario para que ocurra el corte mediado por Cas9; ambos forman una estructura de doble cadena de RNA que dirige a la nucleasa Cas9 hacia un DNA diana donde producirá la escisión del mismo (Wei et al., 2013). Los espaciadores están formadas por secuencias variables únicas, de tamaños similares, que normalmente se encuentran adyacentes a los genes Cas, los cuales codifican para las nucleasas del mismo nombre (Barrangou et al., 2007).

El sitio donde se produce el DSB en el DNA diana, denominado protoespaciador, está compuesto por nucleótidos a los cuales se une el crRNA, y por otra secuencia corta de nucleótidos, que se conoce como motivo adyacente al protoespaciador (PAM, protospacer adjacent motif). Es imprescindible que ambas secuencias estén presentes para que Cas9 se una a la secuencia diana, y generar así un lazo que une el DNA y el crRNA. Así que para que el DNA diana sea reconocido es necesario que exista una secuencia homóloga dentro del crRNA y que la secuencia PAM se encuentre conservada. Todo esto hace que el sistema CRISPR/Cas pueda ser modificado de forma simple, solo modificando el crRNA para que pueda reconocer otro DNA diana diferente (Gasiunas et al., 2012; Jinek et al., 2012). 
La nucleasa Cas9wt es capaz de mediar un DSB sitio específico, lo que puede ser reparado tanto por $\mathrm{RH}$ como también por NHEJ. Para evitar posibles mutaciones que puedan suceder por la utilización de mecanismos propensos a errores, como es el caso de NHEJ, se ha generado una Cas9 mutante (Cong et al., 2013) en la que el aspartato en posición 10 se ha sustituido por una alanina (D10A) en el dominio RuvCl de Cas9wt, con lo cual este dominio deja de ser funcional, y por tanto no es capaz de cortar la cadena desplazada (cadena $5^{\prime} \rightarrow 3^{\prime}$ que no se une al crRNA), como lo hace la nucleasa wt. De esta manera, Cas9 actúa como una nickasa de DNA, y un nick en el DNA genómico es normalmente reparado con alta fidelidad mediante el proceso de $\mathrm{RH}$, lo que minimiza el riesgo de mutagénesis.

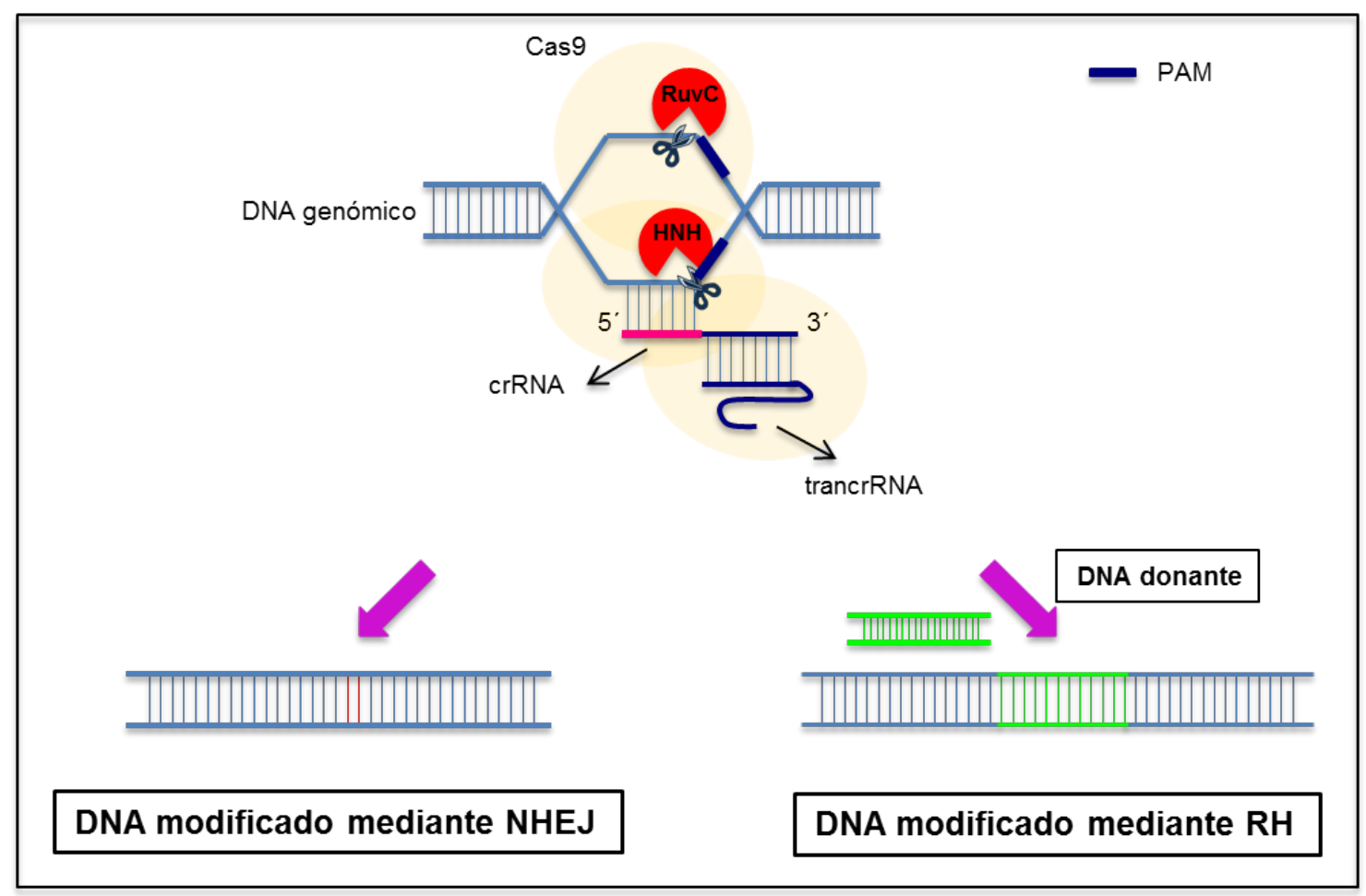

Figura 10. Sistema CRISPR/Cas9. En el sistema CRISPR/Cas9 original, se produce un DSB que puede ser reparado mediante NHEJ o RH. Cuando la nucleasa es mutada en el dominio RuvC, este pierde su capacidad de corte, la nucleasa se convierte en nickasa, y se necesita entonces una pareja de nickasas para poder realizar un corte en la doble hebra, el que va a actuar como un DSB capaz de ser reparado mediante RH en presencia de un DNA donante.

\section{Síndrome de Wiskott-Aldrich.}

\subsection{Manifestaciones clínicas.}

El síndrome de Wiskott-Aldrich (WAS) es una inmunodeficiencia primaria severa de herencia recesiva, ligada al cromosoma $\mathrm{X}$, la cual se caracteriza por la presencia de infecciones recurrentes, eczema y trombocitopenia. Estos pacientes también pueden 
presentar múltiples manifestaciones autoinmunes y tumores, y la expectativa de vida se reduce drásticamente (Massaad et al., 2013).

Entre las manifestaciones clínicas mencionadas anteriormente, las hemorragias causadas por la trombocitopenia con plaquetas pequeñas, son muy frecuentes y se presentan desde formas leves (epistaxis, petequias, etc.), hasta formas muy graves (hemorragia gastrointestinal, sangrado intracraneal, etc.). El $21 \%$ de las muertes en pacientes con WAS son causadas por hemorragias. El $80 \%$ de los pacientes presenta eczema, con diferente grado de severidad y persistencia. Sin embargo, en los casos de WAS severo, el eczema puede ser resistente al tratamiento, lo cual favorece el desarrollo de infecciones oportunistas en la piel. En cuanto a las enfermedades autoinmunes asociadas, las más comunes son la anemia hemolítica autoinmune, la vasculitis cutánea, la artritis y la nefropatía. Es muy común que estos pacientes desarrollen más de una enfermedad autoinmune a la vez. La presencia de estos eventos de autoinmunidad están asociados al desarrollo de tumores, y a un mal pronóstico. La incidencia de tumores es del $22 \%$, y pueden aparecer en la niñez (especialmente la mielodisplasia), sin embargo, son más frecuentes en adolescente y adultos jóvenes. Los tumores asociados a WAS son, principalmente, leucemia, mielodisplasia y linfoma, tienen un muy mal pronóstico, y representan el $25 \%$ de los casos mortales de enfermos con WAS (Bosticardo et al., 2009).

Debido a que las manifestaciones clínicas varían en los diferentes pacientes, se ha diseñado un sistema de evaluación sencillo con el que poder comparar los diferentes fenotipos de la enfermedad, de manera objetiva (Zhu et al., 1997. Imai et al., 2003). Este sistema, permite la posibilidad de diferenciar entre pacientes con síntomas limitados al sangrado y anormalidades en las plaquetas de aquellos paciente con fenotipo clásico de WAS. Es así que, a pacientes que presentan trombocitopenia intermitente o crónica y pequeñas plaquetas se les asigna un valor clasificatorio (o score) de 0.5 o 1 , mientras que a aquellos que presentan eczema transitorio leve e infecciones menores, reciben un score de 2. Las manifestaciones que presentan estos tres grupos de pacientes se las conoce como trombocitopenia ligada al cromosoma $X$ o XLT (X-linked thrombocytopenia), y presentan una esperanza de vida igual a la de cualquier individuo sano, sin embargo, deben ser evaluados periódicamente debido a la posibilidad de que la enfermedad todavía no se haya manifestado por completo. Aquellos pacientes que presentan trombocitopenia, plaquetas pequeñas, eczema constante pero tratable y/o infecciones recurrentes son puntuados con un score 3 (WAS leve); si el eczema se vuelve difícil de tratar y las infecciones recurrentes, entonces el score asignado es de 4 (WAS severo). Por último, aquellos pacientes 
puntuados con un score 5 , son los que desarrollan enfermedades autoinmunes (5A) y/o enfermedades malignas (5B).

\subsection{Mecanismos moleculares del síndrome de Wiskott-Aldrich.}

WASp es una proteína de 502 aminoácidos (figura 11), rica en prolinas, codificada por un gen que contiene 12 exones y que está presente en el cromosoma X (Xp11.2211.23), cuya expresión es exclusiva de células hematopoyéticas (Derry et al., 1994).

Esta proteína contiene dominios de unión a SH3 (del inglés, Src Homolgy 3), dispersos entre las regiones ricas en prolina, los cuales están involucrados en diversas funciones como la señalización celular y la organización del citoesqueleto. Otras regiones que forman parte de WASp son las denominadas WASP 1 y 2 (WH1 y WH2), localizadas en los extremos $\mathrm{N}$ - y C-terminal, respectivamente, y que también están presentes en otras proteínas asociadas al citoesqueleto que contienen regiones ricas en prolinas. Se ha visto que $\mathrm{WH} 1$ se solapa con un dominio de homología con pleckstrina $(\mathrm{PH}$, motivo de unión a lípidos que une dos tipos de fosfatidilinositol fosforilados), quizás mediando la localización de WASp en la membrana, luego de la activación. A este dominio WH1 se une la proteína WIP (proteína que interacciona con WASp, del inglés, WASp-interacting protein). WIP es una proteína rica en prolinas de distribución ubicua que estabiliza los filamentos de actina y que regula la degradación, localización y función de WASP, es decir, WIP actúa como una chaperona para WASp, y su ausencia provoca la degradación de WASp mediante ubiquitinización y posterior degradación proteasómica (de la Fuente et al., 2006). Su deficiencia afecta numerosas funciones celulares dependientes de la reorganización, de los microfilamentos de actina como la activación de linfocitos $\mathrm{T}$ y $\mathrm{B}$, la degranulación de mastocitos, la adhesión de fibroblastos y la migración celular (Antón et al., 2002). A continuación de la región $\mathrm{WH} 1$, se encuentra una región básica $(\mathrm{BR})$ y la región $\mathrm{GBD}$ (un dominio de unión a GTPasa, del inglés, GTPase binding domain), que se ha demostrado que interactúa con la familia Rho GTPasas Cdc42 (Ciclo de división celular 42, del inglés, Cell división cycle 42. Esta es una proteína que interviene en la regulación del ciclo celular), y en menor grado con Rac. Se conoce que la familia Rho de pequeñas GTPasas son miembros de la súper-familia Ras, y que regulan varias vías de señalización, incluidas aquellas que controlan la reorganización del citoesqueleto. Seguido de este dominio, de encuentra el dominio $\mathrm{WH} 2$, en el cual se ha encontrado homología a la región $\mathrm{WH} 2$ en verprolina $(\mathrm{VH}$, una proteína de levadura que interviene en la organización del citoesqueleto) y en WIP. Finalmente, en el extremo C-terminal de WASp existe una región ácida (AR) y un dominio de unión a cofilina. La cofilina es 
una proteína de unión a actina la que, cuando se activa, acelera la despolimerización de los filamentos de actina (Snapper et al., 1999).

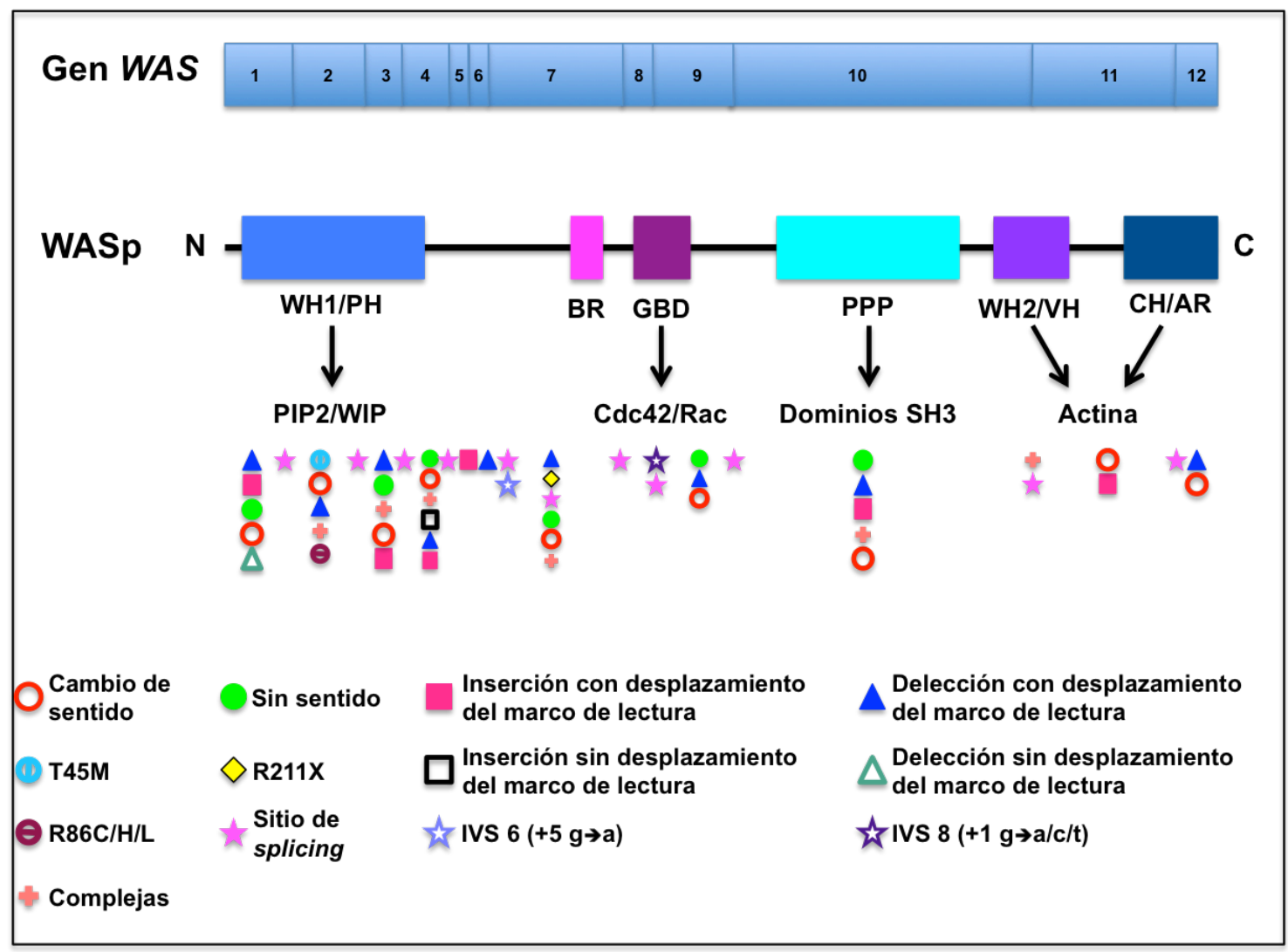

Figura 11. En la figura se observa el gen WAS, con sus 12 exones; la proteína codificada por dicho gen y las mutaciones encontradas a lo largo de todo el gen. Los dominios funcionales de la proteína se representan como rectángulos coloreados, dentro de los cuales podemos ver: dominio de homología a WASP 1/dominio de homología a pleckstrina $(\mathrm{PH})$; región básica (BR), dominio de unión a GTPasa (GBD); región rica en prolina (PPP) con dominios de unión a SH3; dominio de homología a WASP 2 (WH2)/ dominio de homología a verprolina ( $\mathrm{VH})$; dominio de homología a cofilina $(\mathrm{CH})$ /región ácida $(\mathrm{AR})$. Las flechas indican las dianas de los dominios funcionales. Las mutaciones que se muestran en la figura se encontraron tanto en exones como en las uniones de estos con los intrones. Figura tomada y modificada de Snapper et al., 1999; Jin et al., 2004; Massaad et al., 2013.

WASp se presenta en una conformación inactiva (auto-inhibited) y su activación se induce, mayormente, por la unión de la GTPasa Cdc42. Otros factores, como la proteína adaptadora NCK (región no catalítica de la proteína adaptadora de tirosina quinasa, del inglés, non-catalytic region of tyrosine kinase adaptor protein), y la fosforilación de la tirosina en posición 291 de WASp (Y291), pueden activar a WASp, independientemente de Cdc42. La unión del fosfatidilinositol-4,5-bifosfato ( $\left.\mathrm{PIP}_{2}\right)$ también es un importante regulador en la activación de WASp induciendo una conformación estable. La forma activa de WASp, une el complejo de proteínas relacionadas con la actina 2/3 (ARP, actin-related protein), el cual da lugar a la nucleación de los filamentos de actina a los lados de filamentos preexistentes, creando así una red de actina. La actividad del complejo ARP2/3 contribuye en diferentes 
funciones celulares como los cambios de formas en las células, motilidad, endocitosis y fagocitosis (Catucci et al., 2012).

Se han encontrado, aproximadamente, 300 mutaciones capaces de provocar WAS (figura 11). Estas se encuentran a lo largo de todo el gen, aunque mayoritariamente en los primeros 4 exones, y en los exones 7 y 10 (Ariga T., 2012); y dentro de éstas se encuentran mutaciones sin sentido, inserciones, deleciones y mutaciones complejas. Se ha visto que el exón 4 parece ser crítico para la estabilidad y funcionalidad de la proteína, ya que muchas de las mutaciones sin sentido en este exón resultan en niveles indetectables de WASp, o proteínas truncadas o inestables, a pesar de que el transcrito esté presente en valores normales. Todos los pacientes con mutaciones en el exón 4 presentaron un score de 4-5 (Zhu et al., 1997).

Los pacientes con Síndrome de Wiskott-Aldrich sufren de una disminución de células $\mathrm{T}$, lo cual se debe tanto al desarrollo anormal de las mismas, así como también a la elevada tasa de apoptosis. Estas células presentan proyecciones anormales en la superficie, con escasez en el número y estructura de las microvellosidades de la superficie celular, lo que indica un defecto en la arquitectura del citoesqueleto de actina. Los defectos en las células T son la mayor causa de autoinmunidad en WAS. Estos pacientes tienen un defecto en la capacidad de expresar marcadores de activación como CD69 (en linfocitos T y células NK) y CD25 (cadena $\alpha$ del receptor de la interleuquina 2, IL2, en células $T$ y $B$ activadas), así como también defectos en la proliferación y producción de citocinas como IL2, producción de interferón $\gamma(\gamma \mathrm{IFN})$ y factor de necrosis tumoral $\alpha(T N F \alpha)$. Las células T citotóxicas en co-cultivo con células $B$ de linfomas presentan una ineficiente polarización de los gránulos citotóxicos hacia estas células, lo cual explica, posiblemente, el desarrollo de tumores malignos en estos pacientes. En el caso de las enfermedades autoinmunes desarrolladas por estos pacientes, se cree que se deben a la disminución en la proliferación de las células $T$ reguladoras (Treg), las cuales regulan las reacciones del sistema inmune a los antígenos no propios, y promueven la tolerancia a los antígenos propios. A pesar de que las células $B$ no se ven tan afectadas como las $T$, los pacientes con WAS presentan una gran desventaja, ya que estas son menos móviles, difunden menos, y se agregan menos que las células $B$ normales. Todo esto podría deberse a defectos en el citoesqueleto celular (Massaad et al., 2013).

Estos pacientes presentan además disminución en el número de las plaquetas debido a la baja producción de las mismas, y también, a su elevado aclaramiento. Esto puede deberse a que la morfología anormal de estas plaquetas facilite su fagocitosis en la médula ósea, o por los macrófagos del bazo, o también debido a que las mismas son 
reconocidas por anticuerpos que cubren la superficie, lo que facilitaría su opsonización por parte de los macrófagos (Massaad et al., 2013).

Las células natural killer (NK) en pacientes con WAS, tienen su actividad citotóxica severamente disminuida. Las NK forman sinapsis inmunológicas aberrantes, lo cual afecta su capacidad de formar conjugados estables con las células dianas (Massaad et al., 2013).

WASp es importante en la reorganización del citoesqueleto de actina, necesario para la migración eficiente de las células dendríticas (DC), la formación de la sinapsis inmunológica y la activación de células efectoras. Este incorrecto funcionamiento de las DC contribuye con la alta incidencia de infecciones observadas en estos pacientes, debido a la activación disminuida de células efectoras (Massaad et al., 2013).

Los monocitos y los macrófagos presentan menos filopodios que las células normales, tiene muy afectada la capacidad de formar podosomas, y fallan al migrar según gradiente de quimiocinas a pesar de tener una expresión normal para los receptores de quimiocinas. La incapacidad de migrar que presentan estas células se debe a la inestabilidad de los filopodios, que tienden a retraerse con mayor facilidad. En definitiva, la reorganización del citoesqueleto es necesaria para la migración de monocitos y macrófagos hacia los tejidos inflamados o infectados, y para la unión y fagocitosis del antígeno (Massaad et al., 2013).

Por último, los neutrófilos de estos pacientes no son capaces de polimerizar la actina de manera correcta y, por tanto, no son capaces de migrar con normalidad, ni de degranular de forma normal mediante estimulación, y la activación del estallido respiratorio, también llamado explosión o estallido oxidativo, está disminuida (Massaad et al., 2013).

\subsection{Terapia actual.}

A pesar de los avances en el diagnóstico y en los cuidados clínicos, el pronóstico de los enfermos de WAS sigue sin ser demasiado alentador. Hoy en día hay tres tipos de terapias para esta enfermedad.

Por un lado, se encuentra la terapia convencional, que incluye diferentes actuaciones.

En algunos casos, se ha demostrado que la esplenectomía puede restablecer a valores normales el número de plaquetas. Sin embargo, la esplenectomía no reduce los riesgos de enfermedades autoinmunes ni de desórdenes linfoproliferativos. Este tratamiento no es aconsejable para pacientes que se someterán a un trasplante de células madres hematopoyéticas $(\mathrm{CMH})$. Muy a menudo, de manera profiláctica, se 
administran tanto antibióticos como inmunoglobulina intravenosa para disminuir el riesgo de infección (Massaad et al., 2013).

El trasplante de $\mathrm{CMH}$ es el tratamiento de elección en pacientes con WAS, ya que consigue corregir todos los aspectos de la enfermedad, reconstituyendo las funciones hematológicas e inmunes. Sin embargo, diversos factores condicionan el éxito del trasplante, de los cuales lo más importante es el donante y la edad y el estado clínico del paciente con WAS en el momento del trasplante. Los mejores resultados se han obtenido mediante trasplantes de donantes hermanos HLA idénticos, o bien, donantes compatibles sin relación de parentesco, en pacientes menores de 5 años.

La CMH son células capaces de auto-renovarse y de reconstituir el sistema sanguíneo por completo, mediante la generación de los diferentes linajes celulares que lo constituyen. En la práctica clínica habitual, las transfusiones de $\mathrm{CMH}$ o de células diferenciadas (eritrocitos, plaquetas, leucocitos) son utilizadas para tratar diversos desórdenes hematológicos. Sin embargo, la limitada capacidad de encontrar células cuyos donantes y receptores sean compatibles, es uno de los mayores inconvenientes a los que se enfrentan los trasplantes de médula ósea como terapia utilizada en la práctica clínica (Batta et al., 2014). La generación de $\mathrm{CMH}$ a partir de células provenientes del mismo paciente podría evitar así estos inconvenientes, y ampliar las posibilidades para aquellos pacientes que no poseen un donante compatible (Riddell et al., 2014).

Las células madres embrionarias (CME), son células pluripotentes capaces de generar los tres linajes embrionarios: endodermo, ectodermo y mesodermo. Un objetivo que se han planteado numerosos científicos hasta el momento, ha sido la generación de $\mathrm{CMH}$ a partir de estas CME. Sin embargo, a pesar de los esfuerzos realizados no ha sido posible, aún, cultivar células madres hematopoyéticas in vitro, lo cual puede deberse a la falta de conocimiento sobre las vías regulatorias que controlan el desarrollo de $\mathrm{CMH}$ en las etapas tempranas del desarrollo (Sturgeon et al., 2013).

En el año 2006, Takahashi y Yamanaka, observaron que las células adultas diferenciadas podían recrear un estado de pluripotencia, antes de ser re-diferenciadas a un célula de otra estirpe. Para llevar a cabo esta reprogramación se necesita de la expresión ectópica de cuatro factores de pluripotencia: OCT4, SOX2, KLF4 y cMYC. La combinación de estos factores confieren a las células diferenciadas, características de células madres pluripotentes, y por ello se las conoce con el nombre de células madres pluripotentes inducidas (iPSC). Surge así una posible alternativa para poder generar células hematopoyéticas específicas para cada paciente, mediante la diferenciación de iPSC a CMH, aunque desafortunadamente, hasta ahora no se han 
obtenido $\mathrm{CMH}$ que al ser trasplantadas en un paciente, sean capaces de originar todos los linajes celulares. Otro obstáculo importante en este proceso, ha sido que las células sometidas a la expresión forzada de tales factores de pluripotencia pueden llegar a ser transformadas, lo que lleva a un crecimiento sin restricciones, es decir, tumoral, y que además, puede llevar al fracaso en la diferenciación a células sanguíneas maduras (King et al., 2011).

Se han descrito varios métodos para diferenciar células hematopoyéticas a partir de CME e iPSC. Entre ellos se incluyen la formación de cuerpos embrioides, el co-cultivo con células alimentadoras (feeders), y el crecimiento en placas recubiertas de proteínas de matriz extracelular. En el primer método, las colonias de CME e iPSC no diferenciadas, son separadas en pequeños acúmulos de células mediante la utilización de enzimas o mediante disección física, tras lo cual se forman los cuerpos embrioides en suspensión o en una placa de cultivo o mediante una gota colgante. Los cuerpos embrioides con agregados de células, que forman una esfera, que proliferan y se diferencian en las tres capas germinales. Alternativamente, las CME o las IPSC pueden sembrarse sobre células del estroma (OP9), que se obtienen del ratón y que actúan como soporte para la diferenciación de estas células. Finalmente, el último método consiste en utilizar matrices celulares con las que se recubren las placas, como puede ser el colágeno IV, que promueven la proliferación celular y forman una estructura de fijación. En todos los casos, el destino final de las células, es decir, su diferenciación, está controlado mediante el uso de diversas citoquinas (Inoue-Yokoo et al., 2013). Sin embargo, como hemos mencionado anteriormente, hasta el momento no se ha encontrado un método que permitiera cultivar de manera eficaz células madres hematopoyéticas a partir de CME o de iPSC.

Surge así, una nueva opción, la de la reprogramación directa. La reprogramación directa o transdiferenciación, es el proceso por el cual es posible convertir una célula somática en otra de estirpe diferente sin pasar por un estado de pluripotencia intermedio (Jopling et al., 2011). Es así que la transdiferenciación de células derivadas de pacientes, representa una potencial alternativa para la generación de células hematopoyéticas para ser utilizadas en los trasplantes de $\mathrm{CMH}$, sobre todo teniendo en cuenta lo apropiado y conveniente que sería para este propósito reprogramar células diferenciadas y de fácil acceso, como por ejemplo, lo son los fibroblastos (Batta et al., 2014).

Un artículo reciente (Szabo et al., 2010) ha descrito que, mediante transdiferenciación, se han obtenido células hematopoyéticas CD45+ a partir de fibroblastos humanos, sin pasar por un estado de pluripotencia. Para ello, se ha recurrido a la expresión de 
OCT4, junto con un medio de citoquinas adecuado, favorable para la obtención de progenitores hematopoyéticos multipotentes de las líneas mieloide, eritroide y megacariocítica. Sin embargo, cuando se han trasplantado estos precursores en ratones inmunodeficientes, sólo se ha conseguido una modesta diferenciación mieloide, y sin recuperación de la estirpe linfoide; sin embargo, es importante destacar que los precursores hematopoyéticos generados in vitro no fueron capaces de convertirse en células tumorales (Szabo et al., 2010).

En cuanto a los ensayos realizados en ratones, ha sido ya publicado (Batta et al., 2014) que fibroblastos embrionarios y fibroblastos adultos, ambos de ratón, fueron eficientemente transdiferenciados a progenitores hematopoyéticos mediante la expresión ectópica de diferentes factores de transcripción. Estas células transdiferenciadas, poseen la capacidad de reconstitución hematopoyética de todas las series diferenciadas, in vivo, a corto plazo (Batta et al., 2014).

Actualmente existen numerosos grupos trabajando en este campo tanto para poder lograr transdiferenciar células ya diferenciadas a células hematopoyéticas (Riddell et al., 2014), pero también realizar la transdiferenciación a progenitores neurales y endodermo (Mitchell et al., 2014), a células endoteliales (Margariti et al., 2014), a cardiomiocitos (Ifkovits et al., 2014) y a células de los islotes pancreáticos (Lumelsky, 2014).

Finalmente, dentro de las posible terapias para el WAS nos encontramos con la terapia génica, la cual se realiza en pacientes con un score alto en el sistema de Zhu/Imai, que no expresan la proteína y sin donantes HLA compatibles para un trasplante. La terapia génica consiste en aislar $\mathrm{CMH}(\mathrm{CD} 34+)$ del propio paciente, que posteriormente son transducidas ex vivo con un vector viral que contiene el transgén WASp. Finalmente, estas células que ahora contiene el transgén y expresan WASp son introducidas nuevamente en el paciente (Scaramuzza et al., 2013).

El primer ensayo de terapia génica para pacientes con WAS se llevó a cabo en dos pacientes, utilizando un $\gamma \mathrm{RV}$ que contenía el transgén que codifica para WASp y se realizó el seguimiento de ambos durante, al menos, 3 años (Boztug et al., 2010). En los pacientes tratados se comprobó una expresión sostenida de WASp en $\mathrm{CMH}$, células linfoides, células mieloides y plaquetas, hasta 3 años después de haber recibido la terapia génica. Monocitos, células $T$ y $B$ y células $N K$, también demostraron haber corregido sus funciones, lo que conlleva una mejorías clínica. Los signos y síntomas de autoinmunidad, desaparecieron en ambos pacientes dentro del primer año de realizada la terapia génica. El eczema severo solo mejoró en uno de los dos 
pacientes (Catucci et al., 2012). Sin embargo, uno de los pacientes desarrolló un caso de leucemia, probablemente debido a mutagénesis insercional (Avedillo Díez et al., 2011). Estos acontecimientos llevaron, nuevamente, a replantear el tema de la seguridad al utilizar vectores virales. Por ello, se llevaron a cabo diversos estudios haciendo uso de vectores lentivirales SIN. Uno de estos casos de estudio resultó en un protocolo clínico mediante el cual se realizó la terapia génica en 3 pacientes, haciendo uso de un SIN-LV. Tras al menos, 20 meses en observación (entre 32 y 20 meses), los 3 pacientes se encontraban vivos y en buen estado de salud. En los 3 se resolvieron los eczemas, ya sea moderado o severo; también lo hicieron las petequias en la piel en los 3 pacientes, así como el sangrado gastrointestinal, en dos de ellos, y la epistaxis en uno (Aiuti et al., 2013). Estos resultados muestran que los SIN-LVs son más seguros que los vectores $\gamma R V$, y que por tanto, son vectores muy prometedores en el campo de la terapia génica. 
"Hay dos formas de ver la vida: una es creer que no existen milagros, la otra, es creer que todo es un milagro" Albert Einstein (1879 - 1955) 
El objetivo general de la presente tesis es el estudio de condiciones experimentales que mejoren la frecuencia de modificación génica dirigida en células humanas, para poder aplicar estas condiciones en la corrección de mutaciones de células derivadas de pacientes con enfermedades monogénicas de difícil manejo clínico, como es el síndrome de Wiskott-Aldrich.

Los objetivos específicos de este trabajo son:

1. Generación de una línea celular reportera a la que se le ha introducido un gen EGFP mutado incapaz de producir una proteína fluorescente verde.

Producción de un virus adenoasociado que pueda inducir la corrección de la EGFP mutada mediante recombinación homóloga.

2. Estudio del efecto de diferentes tratamientos sobre la frecuencia de recombinación homóloga en nuestro sistema línea reportera - vector donante.

a. Producción de proteínas TALENs para inducir roturas dobles del DNA en el locus EGFP.

b. Producción de la proteína de fusión ScRad52, y estudio de su actividad en la inducción de recombinación homóloga.

c. Estudio del efecto de una librería de siRNAs sobre la frecuencia de recombinación homóloga.

3. Diseño de vectores donantes para la modificación génica dirigida del gen causante del Síndrome de Wiskott-Aldrich.

a. Aplicación de las mejores condiciones para generar fibroblastos primarios que no expresan WASp (WASP-KO).

b. Corrección génica de WASp en fibroblastos primarios WASP-KO (FibsWASP+).

c. Transdiferenciación de fibroblastos corregidos (Fibs-WASP+) a células hematopoyéticas. 


\section{MATERIALES Y MÉTODOS.}

"El mejor científico está abierto a la experiencia, y esta empieza con un romance, la idea de que todo es posible" Ray Bradbury (1920 - 2012) 


\section{MATERIALES.}

\subsection{Líneas y cultivos celulares.}

HCT-116 (ATCC® CCL-247 ${ }^{\mathrm{TM}}$ ): línea celular humana derivada de una muestra de carcinoma colorrectal de un hombre adulto de raza caucásica. Esta línea es de origen epitelial y propiedades adherentes en cultivo. Fue obtenida de la ATCC.

U-2 OS (ATCC $®$ HTB-96 ${ }^{\mathrm{TM}}$ ): línea celular humana derivada de una muestra de osteosarcoma de una niña de 15 años de raza caucásica. Esta línea presenta una morfología epitelial y propiedades adherentes en cultivo. Fue proporcionada por el laboratorio del Dr. Paul J. Anderson de la Universidad de Harvard (Boston, EUA).

Jurkat, Clone E6-1 (ATCC $®$ TIB-152 ${ }^{\mathrm{TM}}$ ): línea celular humana de linfocitos T obtenida de sangre periférica de un niño de 14 años con leucemia linfoide aguda. Esta línea presenta una morfología de linfoblastos y en cultivos se encuentran en suspensión. Fue proporcionada por el Dr. Andrés Alonso García del Instituto de Biología y Genética Molecular (IBGM, Valladolid, España).

Fibroblastos primarios: obtenidos en el Hospital Clínico Universitario de Valladolid, a partir de biopsias de piel de donantes varones, sanos voluntarios que dieron su consentimiento informado.

AAV 293 (293 c18 (ATCC $®$ CRL-10852 $\left.{ }^{\mathrm{TM}}\right)$ ): línea celular humana derivada de células embrionarias primarias de riñón, transformadas con DNA de adenovirus (serotipo 5) para expresar de manera estable proteínas involucradas en la regulación de la transcripción viral (E1A y E1B). Esta línea presenta una morfología epitelial y propiedades adherentes en cultivo. Fue obtenida de la ATCC.

293 FT: línea celular humana de rápido crecimiento derivada de células embrionarias primarias de riñón, transformadas con el antígeno T grande del virus SV40 (SV40 large $T$ antigen). La presencia del antígeno $T$ permite la expresión de altos niveles de proteínas. Estas células expresan de manera estable el gen de resistencia a neomicina del pCMVSPORT6TAg.neo y deben ser mantenidas en un medio que contenga geneticina $(500 \mu \mathrm{g} / \mathrm{mL})$. La expresión de este gen de resistencia está controlado por el promotor de SV40. Se obtuvieron de la compañía Life Technologies $^{\mathrm{TM}}$.

Las líneas celulares HCT-116, U-2 OS, Jurkat y AAV 293 fueron cultivadas en medio Dulbecco's Modified Eagle Medium (DMEM) suplementado con 1X de Glutamax I (concentración final $2 \mathrm{mM}$ ), 10\% de suero fetal bovino (SFB), 1\% de penicilinaestreptomicina (concentración final de $100 \mathrm{U} / \mathrm{mL}$ y $100 \mu \mathrm{g} / \mathrm{mL}$, respectivamente) y $1 \mathrm{X}$ 
de piruvato (concentración final $1 \mathrm{mM}$ ). A partir de este momento, nos referiremos a este medio, como medio completo.

Los fibroblastos primarios fueron cultivados en medio Dulbecco's Modified Eagle Medium (DMEM) suplementado con $1 \%$ de Glutamax I, 10\% de suero fetal bovino (SFB), $1 \%$ de penicilina-estreptomicina (concentración final de $100 \mathrm{U} / \mathrm{mL}$ y $100 \mu \mathrm{g} / \mathrm{mL}$, respectivamente) y $1 \%$ de aminoácidos no esenciales (NEAA). A partir de aquí, nos referiremos a este medio como, medio completo de fibroblastos.

Por último, la línea 293 FT fue cultivada en medio completo al que se le añadió, además, $1 \%$ de NEAA y geneticina $(500 \mu \mathrm{g} / \mathrm{mL})$.

Las condiciones de cultivos para todas las líneas celulares son de $37^{\circ} \mathrm{C}$ y $5 \%$ de $\mathrm{CO}_{2}$.

\subsection{Cepas bacterianas.}

E. coli DH5a: Esta cepa bacteriana se obtuvo de Stratagene. Su genotipo es FendA1 glnV44 thi-1 recA1 relA1 gyrA96 deoR nupG \$80dlacZDM15 $\triangle$ (lacZYA$\arg F) \mathrm{U} 169$, hsdR17(rK- mK+), $\lambda-$.

Posteriormente, y a partir de la cepa comercial, se han obtenido bacterias E. Coli DH5a termocompetentes. Para ello, primero se sembraron las bacterias comerciales en una placa de LB-agar sin antibiótico, la que se incubó durante 16 horas a $37^{\circ} \mathrm{C}$. Una vez transcurrido este tiempo, se picó una colonia aislada y se cultivó en $2 \mathrm{~mL}$ de medio líquido LB, en las mismas condiciones anteriores y con agitación, tras lo cual se inoculó $1 \mathrm{~mL}$ de este cultivo en $50 \mathrm{~mL}$ de LB líquido, y se incubó, nuevamente, a $37^{\circ} \mathrm{C}$ en agitación hasta obtener una densidad óptica, a $600 \mathrm{~nm}$, de 0,4 - 0,6. A continuación, se centrifugó el cultivo a $4.000 \mathrm{rpm}$ durante 5 minutos, y a $4^{\circ} \mathrm{C}$. Se descartó el sobrenadante, y se resuspendió el pellet de bacterias en $15 \mathrm{~mL}$ de tampón CMG (50 mM CaCl y $50 \mathrm{mM} \mathrm{MgCl}_{2}$ ), y se incubó durante 15 minutos en hielo. Una vez más, la suspensión bacteriana se centrifugó en iguales condiciones que las mencionadas anteriormente. Se descartó el sobrenadante y el pellet fue resuspendido en 3,6 mL de tampón CMG, y se incubó nuevamente, en hielo durante 5 minutos. Finalmente, se añadieron $250 \mu \mathrm{L}$ de DMSO, y se incubó por última vez en hielo durante 5 minutos. Las bacterias competentes así obtenidas se almacenaron, alicuotadas, $\mathrm{a}-80^{\circ} \mathrm{C}$.

XL10-Gold: Esta cepa bacteriana se obtuvo de Agilent Technologies. Su genotipo es Tet $^{r} \Delta$ (mcrA) $183 \Delta$ (mcrCB-hsdSMR-mrr)173 endA1 supE44 thi-1 recA1 gyrA96 relA1 lac Hte $\left[F^{\prime}\right.$ proAB lacl ${ }^{q} Z \Delta M 15 \operatorname{Tn} 10\left(\right.$ Tet $\left.^{r}\right)$ Amy Cam $\left.{ }^{r}\right]$. 
E. coli BL21 (DE3): Esta cepa bacteriana fue proporcionada por la Dra. María José Caloca (CSIC - IBGM). Su genotipo es E. coli B dcm ompT hsdS $\left(\mathrm{r}_{\mathrm{B}}{ }^{-} \mathrm{m}_{\mathrm{B}}{ }^{-}\right)$gal. Esta cepa tiene la ventaja de ser deficiente en proteasas, por lo que se utilizan en la producción de proteínas recombinantes.

\subsection{Plásmidos.}

pAAV-CAGGS-EGFP: Este vector de $9.809 \mathrm{bp}$, es un vector donante para modificación génica mediante AAV-ZFN. Presenta un casete de resistencia a ampicilina que permite su selección, y un casete de resistencia a puromicina como marcador de selección. Este plásmido fue obtenido de Addgene, y su número de referencia es el 22.212 .

pAAV-MCS: Este vector de $4.650 \mathrm{bp}$, contiene las repeticiones terminales invertidas (ITR), que flanquean al MCS (sitio de clonación múltiple) y que intervienen directamente en la replicación y encapsidación de las partículas virales. También posee un casete de resistencia a ampicilina que permite su selección. Fue obtenido de Stratagene.

pAAV-RC: Tiene un tamaño de 7.300 bp y contiene los genes Rep y Cap necesarios para la replicación y encapsidación del virus adenoasociado, respectivamente. Obtenido de Stratagene.

pBS-Blasticidin: El plásmido pBS-Blasticidin tiene un tamaño de $4.516 \mathrm{bp}$. De este plásmido se obtiene el casete de Blasticidina flanqueado por dos sitios loxP. Este plásmido fue creado con anterioridad en nuestro laboratorio.

pBluescript K/S +: Este es un vector de clonación de 2961 bp. Contiene un gen que codifica para ampicilina, y también un sitio de clonación múltiple. Fue obtenido de Stratagene.

pEGFP-C1: Este es un vector de expresión en mamíferos que posee un tamaño de $4.731 \mathrm{bp}$, con un gen que codifica para la proteína verde fluorescente mejorada (EGFP, Enhanced Green fluorescent protein) en posición N-terminal en relación con la proteína de interés, un casete de resistencia bacteriana a kanamicina y, como marcador de selección, neomicina. EI MCS de este plásmido se encuentra en el extremo 3' de la EGFP. Se obtuvo de Clontech.

pEGFP-N1: Este es un vector de expresión en mamíferos que tiene un tamaño de $4.733 \mathrm{bp}$, con un gen que codifica para EGFP en posición C-terminal en relación con la proteína de interés, un casete de resistencia bacteriana a kanamicina $\mathrm{y}$, como 
marcador de selección, neomicina. EI MCS de este plásmido se encuentra en el extremo $5^{\prime}$ de la EGFP. Se obtuvo de Clontech.

pET15b: Es un vector de expresión procariota de $5.708 \mathrm{bp}$, que contiene una secuencia que codifica para 6 histidinas en lo que será el extremo $\mathrm{N}$-terminal de la proteína de fusión (His Tag), también posee un casete de resistencia a ampicilina. Este plásmido se obtuvo de Novagen.

pHelper: Tiene un tamaño de 11.635 bp y es necesario para la producción de partículas virales infectivas, ya que contiene las secuencias que codifican para las proteínas E2b, E4 y VA de adenovirus. Se obtuvo de Stratagene.

pMD2.G: Es un plásmido de $5.824 \mathrm{bp}$, que se utiliza en la producción de vectores lentivirales ya que posee un gen que codifica para VSV-G, una proteína involucrada en la formación de la envoltura viral. Posee, además, un casete de resistencia a ampicilina que permite su selección. Este plásmido fue obtenido de Addgene, y su número de referencia es el 12.259.

pSin-EF2-Oct4-Pur: Es un vector lentiviral de expresión en mamíferos de 8.682 bp. Este plásmido contiene una secuencia que codifica para la proteína humana Oct4 (o POU5F1). Posee un casete de resistencia bacteriana a ampicilina, y un casete de resistencia a puromicina como marcador de selección. Este plásmido fue obtenido de Addgene, y su número de referencia es 16.579 .

psPAX2: Es un plásmido involucrado en la formación de vectores lentivirales de segunda generación. Contiene 10.703 bp, en el cuál se encuentra el promotor híbrido CAG (que combina elementos de los promotores de citomegalovirus (CMV), de la $\beta$ actina de pollo y de la $\beta$-globina de conejo) que aumenta la eficiencia en la expresión de las proteínas de Gag, Pol, Tat y Rev del HIV-1, que también son codificadas por el mismo. Este plásmido fue obtenido de Addgene, y su número de referencia es 12.260.

pTriEx-HTNC: Es un vector de expresión bacteriana, constituido por $6.757 \mathrm{bp}$. Este plásmido, contiene una secuencia que codifica para la proteína Cre recombinasa, a la cual se añade en su extremo N-terminal las secuencias NLS, TAT y His Tag. Además, posee un casete de resistencia a ampicilina. Este plásmido fue obtenido de Addgene, y su número de referencia es 13.763 .

pX335-U6-Chimeric_BB-CBh-hSpCas9n(D10A): Es un vector de expresión bacteriana de 8.434 bp que codifica para CRISPR (repeticiones palindrómicas cortas agrupadas y regularmente espaciadas, del inglés clustered regularly interspaced short palindromic repeats), y también para la nucleasa Cas9 (proteína asociada a CRISPR, 
del inglés CRISPR associated protein) de Streptococcus pyogenes que contiene la mutación de aspartato a alanina en posición 10 (D10A). Esta mutación da lugar a una proteína Cas 9 con actividad nickasa. Posee un casete de resistencia bacteriana a ampicilina. Este plásmido fue obtenido de Addgene, y su número de referencia es 42.335 .

TAL-BBL1-ID14: Vector de 2.686 bp que contiene un MCS flanqueado por dos sitios de corte para Mva1269I. Posee un casete de resistencia bacteriana a kanamicina. Este plásmido fue obtenido de Addgene, y su número de referencia es 41.516.

TAL-BBL1-ID21: Vector de 2.698 bp que contiene un MCS flanqueado por dos sitios de corte para Mva1269I. Posee un casete de resistencia bacteriana a kanamicina. Este plásmido fue obtenido de Addgene, y su número de referencia es 41.519.

TAL-BBL1-ID32: Vector de 2.699 bp que contiene un MCS flanqueado por dos sitios de corte para Mva1269l. Posee un casete de resistencia bacteriana a kanamicina. Este plásmido fue obtenido de Addgene, y su número de referencia es 41.518.

TAL-BBL1-ID43: Vector de 2.687 bp que contiene un MCS flanqueado por dos sitios de corte para Mva1269I. Posee un casete de resistencia bacteriana a kanamicina. Este plásmido fue obtenido de Addgene, y su número de referencia es 41.517.

TALEN-ID12-T: Es un vector de expresión en mamíferos de 7.042 bp, que posee una secuencia que codifica para la nucleasa bacteriana Fokl, junto con el promotor CMV. Presenta, además, un casete de resistencia bacteriana a ampicilina. Este plásmido fue obtenido de Addgene, y su número de referencia es 41.479.

\subsection{Oligonucleótidos.}

* Oligonucleótidos para la construcción de vectores.

> Construcción del vector pET15b-ScRad52.

- ScRad52 S:

TGTAAGCTTGAAGAAGAAGAGGAAGGTGTCCATGAATGAAATTATGG ATATGGATG. Introduce sitio de restricción para HindllI.

- ScRad52 AS: ATTCTCGAGTCAAGTAGGCTTGCGTGCATG. Introduce sitio de restricción para Xhol.

\section{Construcción de un vector reportero MCS- $\triangle 3$-EGFPtrunc-vector.}

- RCL A1 S: ATTGCGGCCGCACGAATTCGCCCTTTGCTTTC. Introduce sitio de restricción para Notl. 
- RCL A1 AS: ATCGTCGACGGCGTTACTATGGGAACATACG. Introduce sitio de restricción para Sall.

- RCL A2 S: ATTGTCGACTGTGGATAACCGTATTACCG. Introduce sitio de restricción para Sall.

- RCL A2 AS: ATTGAATTCTTCTCGTTGGGGTCTTTGC. Introduce sitio de restricción para EcoRI.

- RCL A3 S: ATTGAATTCACTAGGGACAGGATTGGTGAC. Introduce sitio de restricción para EcoRI.

- RCL A3 AS: AATGCGGCCGCAGGACGAGAAACACAGCCCC. Introduce sitio de restricción para Notl.

$>$ Construcción de un vector donante MCS- $\Delta 5$-EGFP-donor.

- RCL B1 S: AATAGGGCCCATCCTGGTCGAGCTG. Introduce sitio de restricción para PspOMI.

- RCL B1 As: TAAGTCGACGTTAAGATACATTGATGAGTTTG. Introduce sitio de restricción para Sall.

- RCL A3 S: ATTGAATTCACTAGGGACAGGATTGGTGAC. Introduce sitio de restricción para EcoRI.

- RCL A3 AS: AATGCGGCCGCAGGACGAGAAACACAGCCCC. Introduce sitio de restricción para Notl.

$>$ Construcción de un vector donante pAAV-MCS-WASP-wt.

- WASP A1 S: ATAGCGGCCGCTCAACTCCAACCCCCAAATAC. Introduce sitio de restricción para Notl.

- WASP A1 AS: ATTGTCGACATCCATCAGTCCACACATCC. Introduce sitio de restricción para Sall.

- WASP A2 S:

ATTGAATTCGCAGGGCTGTGATAACTCTCTGGATGGATTGG. Introduce sitio de restricción para EcoRI.

- WASP A2 As: AATGCGGCCGCTGTCCATACATCTGTCTCTG. Introduce sitio de restricción para Notl.

$>$ Construcción del vector p-AAV-MCS-WASP-KO. Mutación dirigida.

- R148X168ins S:

CGTGCAGGAGAAGATACAAAAAAAGGAATCAGAGGC.

- R148X168ins AS: GCCTCTGATTCCTTTTTTTGTATCTTCTCCTGCACG.

* Oligonucleótidos para screening mediante PCR.

> Screening en la línea celular reportera HCT116-RCL. 
- RCLS1 S: GACCACTTTGAGCTCTACTG.

- RCLS1 AS: CCGCATGTTAGAAGACTTCC.

- RCLS2 S: CGACCACTACCAGCAGAAC.

- RCLS2 AS: CCAAGTGGTTGATAAACCCAC.

- RCLS3 S: CCACCCCATTGACGTCAATG.

- RCLS3 AS: GTGAAATTTGTGATGCTATTGC.

> Screening en la línea WASP-KO y en WASP-wt.

- WASP S1.1 S: GAAGGTGAGGCTGCAAACAG.

- WASP S1.2 S: GCAGGGCTGTGATAACTCTC.

- WASP S1 AS: CCATAGTTTGTGGTGCTGATC.

* Oligonucleótidos para determinación de título viral.

$>$ Título AAV.

- ITR S: GgAACCCCTAGTGATGgAGTT.

- ITR AS: CGGCCTCAGTGAGCGA.

$>$ Título LV.

- LV-OCT-4 S: ACTTGAaAgCGaAaggGaAaC.

- LV-OCT-4 AS: CACCCATCTCTCTCCTTCTAGCC.

* Oligonucleótidos para la construcción de CRISPR/Cas9.

$>$ Pareja 1.

- CRISPR-WASP1 S: CACCGAGGTATGTGGATGGACGAGC.

- CRISPR-WASP1 AS: AAACGCTCGTCCATCCACATACCTC.

$>$ Pareja 2.

- CRISPR-WASP2 S: CACCGTGGATGGATTGGCGGTAGA.

- CRISPR-WASP2 AS: AAACTCTACCGCCAATCCATCCAC.

\subsection{Reactivos}

Ampicilina: en forma de sal sódica (CALCIOCHEM). Se utilizó en todos los cultivos a una concentración de $100 \mu \mathrm{g} / \mathrm{mL}$.

Azul de tripán (Trypan Blue): colorante azoico que se utiliza para ensayos de viabilidad, ya que permiten diferenciar células vivas de células muertas, debido a que estas últimas permiten el paso del colorante a través de la membrana.

Blasticidina S: antibiótico utilizado como marcador de selección, aislado de Streptomyces griseochromogenes. Solución $10 \mathrm{mg} / \mathrm{mL}$ (InvivoGen). 
Cre recombinasa: Se utilizaron dos, una comercial Cre recombinase (Clontech), y otra, una proteína de fusión (His-TAT-NLS-Cre) producida en el laboratorio.

Determinación colorimétrica de proteínas: RC DC ${ }^{\mathrm{TM}}$ Protein Assay (compatible con agentes reductores y detergentes. Bio-Rad). Basado en el método de Lowry.

DMEM, Dulbecco's Modified Eagle Medium con glucosa alta $(4.5 \mathrm{~g} / \mathrm{L})$ y sin glutamina (LONZA).

DNA Polimerasas para PCR: Se utilizaron dos enzimas. Por un lado la Phusion Hot Start High-Fidelity DNA Polymerase (Thermo Scientific). Y por otro lado, la i-StarTaq ${ }^{\mathrm{TM}}$ Hot Start DNA Polymerase (iNtRon Biotechnology).

Geneticina: aminoglicósido aislado de Micromonospora rhodorangea (Gibco).

GlutaMAX I: 100X (Gibco). Se utiliza de manera alternativa a la L-glutamina ya que, a diferencia de esta, no se descompone espontáneamente para formar amoníaco, sino que las células escinden el enlace dipéptido para liberar L-glutamina, según sea necesario. Este sistema mantiene un suministro fresco de L-glutamina durante el cultivo a largo plazo. La concentración final en cultivos es de $2 \mathrm{mM}$.

Kanamicina: en forma de sulfato de kanamicina, aislada de Streptomyces kanamyceticus (CALBIOCHEM). Se utilizó en los cultivos a una concentración de 30 $\mu \mathrm{g} / \mathrm{mL}$.

Kit de fijación y permeabilización celular para citometría: FIX \& PERM, Cell permeabilization kit (An Der Grub Bio Research GMBH).

Kit de ligación: Rapid DNA Dephos \& Ligation kit (Roche).

Marcador de peso molecular: GeneRuler $1 \mathrm{~Kb}$ Plus, cuyo rango de pesos es 75 a 20.000 bp (Thermo Scientific).

Meganucleasa: CompoZr ${ }^{\circledR}$ Targeted Integration Kit - AAVS1 (Sigma-Aldrich).

Midipreps: PureLink ${ }^{\mathrm{TM}}$ HiPure Plasmid Filter Midiprep Kit, (Invitrogen)

Mutagénesis dirigida: QuickChange II Site-Directed Mutagenesis Kit (Agilent Technologies).

Nucleofección: Se utilizaron dos kits, Amaxa® Cell Line Nucleofector® Kit V (Lonza) y Amaxa® NHDF Nucleofector® Kit (Lonza).

Penicilina-Estreptomicina $10.000 \mathrm{U} / \mathrm{mL}$ (Gibco). Concentración final en cultivos, $100 \mathrm{U} / \mathrm{mL}-100 \mu \mathrm{g} / \mathrm{mL}$.

Piruvato de sodio: $100 \mathrm{mM}$ (Gibco). La concentración final en cultivos es de $1 \mathrm{mM}$. 
Purificación DNA/RNA viral: PureLink ${ }^{\mathrm{TM}}$ Viral RNA/DNA Mini Kit (Invitrogen).

Purificación en gel: Wizard® SV Gel and PCR Clean-Up System (Promega).

Puromicina: utilizado como antibiótico de selección en forma de dihidrocloruro de puromicina obtenida a partir de Streptomyces alboniger (Sigma-Aldrich).

Revelado de películas fotográficas mediante quimioluminiscencia: Pierce ECL Western Blotting Substrate (Thermo Scientific).

Fosfatasa alcalina de camarones: SAP (Thermo Scientific).

TALENs: LIC TAL Effector Assembly Kit (Addgene. Cat\#1000000023).

Transcriptasa reversa: iScript ${ }^{\mathrm{TM}}$ cDNA Synthesis Kit (Bio-Rad).

Transfección mediante fosfato de calcio: CalPhos ${ }^{\mathrm{TM}}$ Mammalian Transfection Kit (Clontech).

Transfección mediante liposomas catiónicos: Se utilizaron dos kits de transfección, Lipofectamine ${ }^{\circledR} 2000$ (Life Technologies) y TransIT-X2 ${ }^{\text {TM }}$ Dynamic Delivery System (Mirus Bio LLC).

\section{Anticuerpos para western blot:}

- Anticuerpo primario monoclonal anti-polyHistidina ( $\alpha$-polyHistidina), producido en ratón (Monoclonal Anti-polyHistidine, Clone HIS-1 produced in mouse. H1029, SIGMA-ALDRICH).

- Anticuerpo secundario anti-IgG de ratón Fab específico ( $\alpha$-lgG de ratón), marcado con peroxidasa de rábano, producido en cabra (Anti-Mouse IgG (Fab specific)Peroxidase produced in goat. A2304, SIGMA-ALDRICH),

- Anticuerpo primario policlonal anti-WASPK374 ( $\alpha$-WASPK374), producido en conejo. Generosa donación del Dr. Raif S. Geha (Servicio de Inmunología, Children's Hospital. Boston, USA).

- Anticuerpo secundario anti-lgG de conejo ( $\alpha-\operatorname{lgg}$ de conejo), marcado con peroxidasa de rábano, producido en burro (Rabbit lgG, HRP-linked whole $A B$ from donkey. 25800685. Amersham).

\section{Anticuerpo para citometría de flujo:}

- Anticuerpo anti-CD45-PE-Cy7 ( $\alpha$-CD45-PE-Cy7. PE-Cy7 conjugated mouse antihuman CD45. BD Pharmingen ${ }^{\mathrm{TM}}$ ). 
- Anticuerpo anti-WASP-APC ( $\alpha$-WASP-APC) generado por el Dr. Miguel Ángel de la Fuente en el Servicio de Inmunología, Children's Hospital. Boston, USA.

\section{MÉTODOS.}

\subsection{TÉCNICAS BÁSICAS DE BIOLOGÍA MOLECULAR.}

\subsubsection{Transformación bacteriana.}

Para realizar la transformación bacteriana, se descongelan las bacterias Escherichia coli (cepas DH5 $\alpha$, BL21 (DE3), XL1-Blue supercompetentes y XL 10 gold) termo competentes en hielo. A $50 \mu \mathrm{L}$ de la solución bacteriana descongelada, se le añaden $50 \mathrm{ng}$ de plásmido o $2 \mu \mathrm{L}$ del producto de ligación (10-30 ng). Según la cepa bacteriana que estemos utilizando, se deja la mezcla en hielo entre 5 - 30 minutos. Transcurrido este tiempo, se somete a un choque térmico, el cual también depende de la cepa bacteriana. Al término de esta sección se detallan las condiciones de incubación en hielo y de choque térmico para cada una de las cepas Escherichia coli empleadas. Luego se incubó la muestra otros 2 minutos en hielo, tras lo cual se añade $1 \mathrm{~mL}$ de LB líquido y se incubó 1 hora a $37^{\circ} \mathrm{C}$ en agitación. Posteriormente, se centrifugó la muestra 2 minutos a $12.000 \mathrm{rpm}$ y se retiraron $900 \mu \mathrm{L}$ del sobrenadante. Se resuspendió el pellet bacteriano, que se sembró en placa de LB agar con el antibiótico de selección correspondiente al plásmido transformado. Las placas se incuban durante toda la noche a $37^{\circ} \mathrm{C}$.

DH5 $\alpha$ : Incubación de 20 minutos en hielo; choque térmico de 55 segundos a $43^{\circ} \mathrm{C}$.

BL21: Incubación de 5 minutos en hielo; choque térmico 45 segundos a $42^{\circ} \mathrm{C}$.

XL1-Blue supercompetentes: Incubación de 30 minutos en hielo; choque térmico 45 segundos a $42^{\circ} \mathrm{C}$.

XL10 gold: Incubación de 30 minutos en hielo; choque térmico 30 segundos a $42^{\circ} \mathrm{C}$. Previo a la transformación, a estas bacterias se les añaden $2 \mu \mathrm{L}$ de $\beta$-mercaptoetanol y se dejan durante 10 minutos en hielo, para aumentar la eficiencia de transfección.

\subsubsection{Purificación de plásmidos a pequeña escala (minipreps).}

Tomándose colonias aisladas de una placa de LB agar en presencia del antibiótico de selección correspondiente, se cultivaron en $2 \mathrm{~mL}$ de medio LB líquido en presencia del mismo antibiótico durante toda la noche a $37^{\circ} \mathrm{C}$ en agitación. El pellet bacteriano, 
obtenido mediante centrifugación del cultivo, se resuspendió en $100 \mu \mathrm{L}$ de tampón de resuspensión (50 mM Tris / $10 \mathrm{mM}$ EDTA / RNAsa $50 \mu \mathrm{g} / \mathrm{mL} / \mathrm{pH}=8.0$ ). Luego, se añadieron $100 \mu \mathrm{L}$ de tampón de lisis $(0,1 \mathrm{M} \mathrm{NaOH} / 1 \%$ SDS), se mezclaron las soluciones por inversión y se incubó 4 minutos a temperatura ambiente. Transcurrido este tiempo, se añadieron $100 \mu \mathrm{L}$ de tampón neutralizador (1,5 M de acetato potásico / $\mathrm{pH}=5,5)$, se mezcló nuevamente por inversión y se centrifugó 5 minutos a $15.000 \mathrm{rpm}$. Se recogió el sobrenadante y se añadieron $900 \mu \mathrm{L}$ de etanol absoluto (100\%) frío para precipitar el DNA plasmídico. Se invirtieron los viales para mezclar las soluciones y se incubaron durante 10 minutos a $-20^{\circ} \mathrm{C}$. Finalmente, se centrifugaron las muestras a 15.000 rpm durante 10 minutos, tras lo cual se retiró el sobrenadante y se lavó el pellet con $700 \mu \mathrm{L}$ de etanol al $70 \%$. Las muestras se centrifugaron una vez más a 15.000 rpm durante 5 minutos, se retiró el sobrenadante y se dejó secar al aire el pellet durante 5 minutos a temperatura ambiente. Por último, se resuspendió el DNA plasmídico en $50 \mu \mathrm{L}$ de TE $1 \mathrm{X}$ y se utilizó el espectrofotómetro de microvolúmenes NanoDrop (Thermo Fisher) para su cuantificación.

\subsubsection{Purificación de plásmidos a mediana escala (midipreps).}

La extracción de plásmidos a mediana escala se realizó utilizando el kit comercial PureLink $^{\mathrm{TM}}$ HiPure Plasmid Filter Midiprep Kit (Invitrogen). El principio de este kit se basa en la lisis alcalina de las bacterias, seguido por la absorción del DNA a una membrana de sílica presente en una columna que separa el DNA de resto de la muestra.

Las células procedentes de $100 \mathrm{~mL}$ de cultivo se resuspendieron en $4 \mathrm{~mL}$ de tampón R3 (tampón de resuspensión). A continuación se añadieron $4 \mathrm{~mL}$ de tampón $\mathrm{L} 7$ (tampón de lisis), se mezclaron las soluciones mediante inversión y se incubó 5 minutos a temperatura ambiente. Se añadieron luego, $4 \mathrm{~mL}$ del tampón N3 (tampón neutralizador), tras lo cual se invirtió nuevamente para mezclar las soluciones e, inmediatamente, se centrifugó a $12.000 \mathrm{rpm}$ durante 10 minutos a $4^{\circ} \mathrm{C}$. Se añadió el sobrenadante a una columna de sílica previamente equilibrada con $10 \mathrm{~mL}$ de tampón EQ1 (tampón equilibrador). Una vez que todo el líquido ha atravesado la membrana, la columna se lavó con $10 \mathrm{~mL}$ de tampón W8 (tampón de lavado). El DNA se eluyó, finalmente, con $5 \mathrm{~mL}$ de tampón E4 (tampón de elución), se precipitó añadiendo 3,5 $\mathrm{mL}$ de isopropanol, y se centrifugó $30 \mathrm{~min}$ a $9500 \mathrm{rpm}$. El precipitado así obtenido se lavó con etanol al 70\%, y se volvió a centrifugar para eliminar los restos del alcohol. Finalmente, se resuspendió el DNA en TE, se cuantificó y almacenó a $-20^{\circ} \mathrm{C}$. 


\subsubsection{Ligación.}

Para realizar una ligación, preparamos primero los DNAs (vector e inserto/s) purificados. La relación molar del DNA vector con respecto al DNA del inserto fue de $1: 3$.

Para llevar a cabo la reacción de ligación, primero debemos disolver el DNA del vector y el DNA del inserto en el tampón de dilución (5X DNA dilution buffer). Esto se lleva a cabo en un volumen final de $10 \mu \mathrm{L}$, el que se ajusta utilizando $\mathrm{H}_{2} \mathrm{O}$ ultrapura. A continuación, se añaden $10 \mu \mathrm{L}$ del tampón de ligación (2X T4 DNA ligation buffer), y se mezcla. Para finalizar, se añade $1 \mu \mathrm{L}$ de la enzima ligasa (T4 DNA ligase) y se incuba durante 5 minutos a temperatura ambiente. En el caso de que el volumen de la primera parte de la reacción supere los $10 \mu \mathrm{L}$, los siguientes volúmenes deben ser también ajustados, y el tiempo de reacción será de 20 minutos.

La reacción de ligación se utiliza inmediatamente para transformar bacterias competentes, o bien, se almacena a $-20^{\circ} \mathrm{C}$.

\subsubsection{Reacción en cadena de la polimerasa (PCR).}

La reacción se realizó siempre en un volumen final de $50 \mu \mathrm{L}$. Se utilizaron las siguientes concentraciones finales para cada reactivo: $1 \mathrm{X}$ de tampón de reacción (7.5 $\mathrm{mM} \mathrm{Cl} 2 \mathrm{Mg}$ ), $200 \mu \mathrm{M}$ de dNTPs, $400 \mathrm{pM}$ de cada uno de los primers (sense $y$ antisense) y 0,75 $U$ de enzima DNA polimerasa. La cantidad de DNA utilizada en las diferentes reacciones realizadas varió entre 50 y $150 \mathrm{ng}$. Las condiciones utilizadas, variaron según reacción, y se comentarán en la sección correspondiente. El termociclador utilizado fue el MyCycler ${ }^{\mathrm{TM}}$ Thermal Cycler de Bio-Rad.

\subsubsection{Extracción de DNA a partir de un cultivo celular.}

Se recogen las células en cultivo (en caso de ser un cultivo adherentes, estas deben tripsinizarse previamente), se centrifuga para eliminar el sobrenadante y se añade el tampón de lisis (50 mM Tris-HCl. pH 8 / 100 mM NaCl / 10 mM EDTA / 0,5\% SDS / $300 \mu \mathrm{g} / \mathrm{mL}$ proteinasa $\mathrm{K}$ ), tras lo cual se incuba a $56^{\circ} \mathrm{C}$ durante 1 hora. Transcurrido este tiempo, se añaden $600 \mu \mathrm{L}$ de etanol absoluto, un $10 \%$ del volumen inicial de $\mathrm{NaCl}$ $5 \mathrm{M}$ y $2 \mu \mathrm{L}$ de glicógeno $(20 \mathrm{mg} / \mathrm{mL})$, y se incuba durante 20 minutos a $-20^{\circ} \mathrm{C}$, para precipitar el DNA. Una vez cumplido este tiempo, el DNA ha precipitado por lo que se 
centrifuga a $12.000 \mathrm{rpm}$ por otros 20 minutos. Se retira completamente el sobrenadante y se añaden $600 \mu \mathrm{L}$ de etanol $70^{\circ}$ y se centrifuga nuevamente, durante 10 minutos. Se retira una vez más el sobrenadante, y se deja secar el pellet un par de minutos al aire. Finalmente se resuspende en tampón TE que contiene RNAs a 50 $\mu \mathrm{g} / \mathrm{mL}$.

\subsubsection{Electroforesis en gel de poliacrilamida (SDS-PAGE).}

Diferentes alícuotas de proteínas fueron desnaturalizadas, hirviéndolas a $95^{\circ} \mathrm{C}$ durante 5 minutos en presencia del tampón de carga reductor Laemmli $(50 \mathrm{mM}$ Tris- $\mathrm{HCl}$. $\mathrm{pH}=$ 6,8 / 2\% SDS / 10\% glicerol / 1\% azul de bromofenol / $25 \mathrm{mM}$ ditiotreitol). Posteriormente, fueron cargadas en un gel de poliacrilamida, en paralelo con el marcador de peso molecular. La electroforesis se realizó utilizando un tampón TrisGlicina (2,5 mM Tris / 19,2 mM de Glicina / 0,01\% de SDS / pH=8,3), durante 15 minutos a $50 \mathrm{~V}$, y luego por, aproximadamente, 60 minutos a $150 \mathrm{~V}$. Una vez acabada la electroforesis, cuando el frente de azul de bromofenol alcanzó la parte inferior del gel, los geles fueron, o bien teñidos con azul de Coomassie, o bien utilizados para realizar un Western Blot.

\subsubsection{Tinción de geles de poliacrilamida con azul de Coomassie.}

Los geles a teñir, fueron sumergidos en el colorante azul de Coomassie durante 10 minutos y, luego, decolorados con solución decolorante (20\% de metanol / $10 \%$ de ácido acético / 70\% de agua), durante el tiempo necesario hasta que las bandas correspondientes a las proteínas fueran observadas claramente y sin interferencias de colorante.

\subsubsection{Western Blot.}

Los geles a utilizarse para WB, fueron sometidos en primera instancia a una transferencia. La misma se realizó sobre una membrana de PVDF previamente tratada con metanol. La transferencia fue realizada por 60 minutos a $110 \mathrm{~V}$. Al finalizar la misma, la membrana fue bloqueada con solución de bloqueo TTBS (20 MM Tris base / $150 \mathrm{mM} \mathrm{NaCl} / 0,1 \%$ Tween20 / pH=7,6) con $5 \%$ de leche en polvo y $5 \%$ de BSA durante toda la noche a $4^{\circ} \mathrm{C}$. 
Al día siguiente se realizó un breve lavado con TTBS, tras lo cual se añadió el anticuerpo primario en solución de bloqueo diluida diez veces en TTBS, durante 60 minutos. El anticuerpo secundario marcado con peroxidasa también se utilizó en solución de bloqueo diluida diez veces, durante 30 minutos. Tras la incubación con cada uno de los anticuerpos, se realizaron tres lavados de 10 minutos cada uno, con TTBS.

Por último, se realizó la detección mediante quimioluminiscencia, para lo cual la membrana fue sumergida en una solución conformada por iguales volúmenes de las soluciones de luminol y peroxidasa que componen el kit de revelado. Esto se incubó a temperatura ambiente durante 1 minuto, tras lo cual se quitó el excedente líquido y se procedió a revelar la membrana. La película fotográfica y la membrana, fueron enfrentadas a diferentes tiempos hasta encontrar aquel en que se apreciaron mejor las proteínas en estudio.

\subsection{Generación de proteínas de fusión. Cre recombinasa y ScRad52.}

Los cDNAs codificantes para las proteínas Cre recombinasa y ScRad52 se subclonaron en un plásmido, in frame con un casete aminoterminal compuesto por las regiones His-tag, Tat y NLS (sentido $5^{\prime} \rightarrow 3^{\prime}$ ).

- His-Tag: esta secuencia codifica para seis residuos de histidinas que estarán presentes en la proteína de fusión. La presencia de esta cola de histidinas permite que la proteína pueda ser reconocida por un anticuerpo $\mathrm{y}$, principalmente permite su posterior purificación mediante cromatografía de afinidad, utilizando resinas de níquel. El níquel se une a la cola de histidinas, lo que permite la separación de la proteína de interés del resto de las proteínas.

- Tat: Esta secuencia que codifica 11 aminoácidos proviene de la proteína viral del virus de la inmunodeficiencia humana VIH. El nombre de esta proteína es derivado de Trans-Activator of Transcription (transactivador de la transcripción genética). Tat está compuesta por un número de aminoácidos que oscila entre 86 y 101, dependiendo del subtipo de cada molécula. En 1988 Green y Frankel descubrieron, de manera independiente, que la proteína Tat del VIH es capaz de atravesar las membranas de las células eucariotas y localizarse en el núcleo, donde incrementa la transcripción de la cadena genética del VIH. En 1994, se demostró la existencia de un dominio de 36 aminoácidos en Tat capaz de conferir a otras proteínas la habilidad de atravesar las 
membranas celulares cuando se entrelazaba químicamente a ellas (Fawell et al., 1994). Eguchi describió que la secuencia peptídica responsable de la penetración a través de la membrana contiene un dominio PTD (del inglés Protein Transduction Domain, en español dominio de transducción proteica) rico en aminoácidos básicos (argininas y lisinas), los cuales están involucrados en el contacto con las cargas negativas de los lípidos de la membrana, desestabilización de la bicapa lipídica y penetración celular (Eguchi et al., 2001). En nuestro caso, el péptido utilizado es de 11 aminoácidos, que se ha demostrado suficiente para permitir la internalización de las proteínas.

- NLS (del inglés Nuclear Localization Signal, en español Señal de localización nuclear) es una secuencia de aminoácidos que marcan una proteína para su importación al núcleo celular. Típicamente, esta señal se compone de una o más secuencias cortas de lisinas o argininas cargadas positivamente, expuestas en la superficie de la proteína. Diferentes proteínas pueden compartir la misma NLS.

A continuación se detalla el procedimiento empleado para la generación de las construcciones plasmídicas realizadas y la obtención de cada una de las proteínas recombinantes.

\subsubsection{Diseño y construcción de un plásmido de expresión bacteriana para la proteína recombinante Cre recombinasa.}

Para obtener esta proteína de fusión se utilizó, en primera instancia, el plásmido comercial pTriEx-HTNC. A partir de éste, se realizó una digestión con las enzimas de restricción $\mathrm{Ncol}$ y Xhol, durante 1 hora a $37^{\circ} \mathrm{C}$, para liberar el fragmento que contiene el cDNA de Cre. Posteriormente, la muestra fue sometida a una electroforesis en gel de agarosa al $1 \%$, donde se esperaba obtener dos bandas de $5,6 \mathrm{~kb}$ y $1,1 \mathrm{~kb}$. La banda de interés es la de menor tamaño, que es la que contiene la secuencia correspondiente a His-tag, TAT, NLS y Cre, que al ser observada en el gel, fue cortada y purificada con columnas.

En paralelo, se realizó la digestión del vector de expresión bacteriana pET15b con las mismas enzimas ( $\mathrm{Ncol}$ y Xhol). Con esto se logra linearizar el vector, perdiéndose unas 65 bp correspondientes a His-tag que también se encuentra en este vector.

El fragmento así obtenido, Ncol-His-TAT-NLS-ScRad52-Xhol fue clonado en el vector definitivo, el pET15b con el cual se transformaron bacterias BL21 deficientes en 
proteasas con las cuales se realizó posteriormente la inducción mediante IPTG de la expresión proteica.

\subsubsection{Diseño y construcción de un plásmido de expresión bacteriana para la proteína recombinante ScRad52.}

El gen ScRad52 se amplificó mediante PCR del DNA genómico de Sascharomyces cerevisiae. Esta se llevó a cabo utilizando los primers ScRad52 S y ScRad52 AS y la enzima Phusion Hot Start, con las siguientes condiciones de reacción: 1 ciclo de 1 minuto a $98^{\circ} \mathrm{C} ; 35$ ciclos de $\left[15\right.$ segundos a $98^{\circ} \mathrm{C}, 20$ segundos a $59^{\circ} \mathrm{C}$ y 75 segundos a $72^{\circ} \mathrm{C}$; $y$, en última instancia, 1 ciclo de 5 minutos a $72^{\circ} \mathrm{C}$.

Una vez finalizada la reacción, la muestra fue sometida a una electroforesis en gel de agarosa al $1 \%$. A partir del gel se obtuvo una banda de $1,5 \mathrm{~kb}$, la cual fue cortada y purificada mediante columna, y luego digerida con HindlII y Xhol durante 1 hora a $37^{\circ} \mathrm{C}$. Al cumplirse el tiempo, la muestra fue nuevamente purificada mediante columna y luego, cuantificada en NanoDrop.

Este fragmento HindlII-ScRad52-Xhol fue subclonado en el vector intermedio pTriExHTNC, inmediatamente a continuación de la secuencia His-TAT-NLS. Una vez obtenido este nuevo vector con nuestro inserto, mediante digestión con Ncol y Xhol, obtenemos el fragmento que hemos de introducir en el plásmido final. Este fragmento, Ncol-His-TAT-NLS-ScRad52-Xhol fue finalmente clonado en el vector de expresión bacteriana $\mathrm{pET} 15 \mathrm{~b}$ y con el cual se transformaron bacterias BL21 deficientes en proteasas con las cuales se realizó posteriormente, tal como se hizo para Cre recombinasa, la inducción mediante IPTG de la expresión proteica.

\subsubsection{Expresión y purificación de Cre recombinasa y ScRad52.}

Cómo no se conocían las condiciones apropiadas para expresar e inducir cada una de estas proteínas, se realizaron en principio una serie de experimentos para ajustar las condiciones ideales tanto para Cre recombinasa, como para ScRad52.

En primer lugar, para ambas se ha utilizado medio LB líquido con ampicilina, en el cual se inocularon las cepas de bacterias BL21 transformadas con los plásmidos correspondientes a ScRad52 y Cre recombinasa, respectivamente. Estos cultivos se incubaron durante 16 horas a $37^{\circ} \mathrm{C}$. 
Al día siguiente, se realizaron varias diluciones 1:20 de ambas cepas de bacterias transformadas, incubándose por 2 horas más a $37^{\circ} \mathrm{C}$.

Una vez transcurrido este tiempo se procedió a añadir IPTG (isopropil- $\beta$-D-1tiogalactopiranósido) para inducir la expresión de la proteína. EI IPTG se utilizó a 1 $\mathrm{mM}$, como concentración final, el tiempo de inducción fue de 3 horas y la temperatura de incubación de $37^{\circ} \mathrm{C}$. Todo esto se realizó frente a la condición control en la cual no se añadió IPTG, pero donde se mantuvieron todas las condiciones restantes.

Posteriormente, las células fueron recogidas por centrifugación, y congeladas a $-80^{\circ} \mathrm{C}$.

A continuación se realizó el fraccionamiento proteico, para separar las proteínas que se encuentran en la parte soluble e insoluble. El pellet así obtenido fue posteriormente tratado mediante lisis química con tampón B-PER (4 mL/g de pellet) y complementado con DNAsa: $20 \mathrm{U} / \mathrm{g}$ de pellet, lisozima: $400 \mu \mathrm{L} / \mathrm{g}$ de pellet, inhibidor de proteasas: 24 $\mu \mathrm{L} / \mathrm{g}$ de pellet. El pellet de resuspendió en esta mezcla, y se dejó durante 15 minutos a temperatura ambiente. Luego se centrifugaron las muestras durante 10 minutos a $11.000 \mathrm{rpm}$ y $4^{\circ} \mathrm{C}$. Las proteínas solubles se encuentran en el sobrenadante, y las insolubles en el pellet.

Una vez obtenido el sobrenadante, se procedió a purificar las proteínas, utilizando bolas de Ni-Sefarosa. Para ello, se tomaron 1,4 mL de la suspensión de bolas en $20 \%$ de etanol, por litro de cultivo inducido. Ese volumen de suspensión se lavó previamente con 3 porciones de $700 \mu \mathrm{L}$ de agua milliQ y otras 3 veces con $700 \mu \mathrm{L}$ de tampón de unión (20 mM Tris-HCl. pH=7,9 / 500 mM NaCl / 5 mM Imidazol). Una vez realizados los lavados, se añadió el lisado obtenido de centrifugar las muestras ya fraccionadas, es decir, las proteínas solubles. Esto se dejó en agitación a $4^{\circ} \mathrm{C}$ durante 1 hora, tras lo cual, se centrifugó y lavó dos veces con $1 \mathrm{~mL}$ del mismo tampón de unión utilizado anteriormente. Luego otros cuatro lavados con $1 \mathrm{~mL}$ de tampón de lavado, de igual composición que el tampón de unión, variando únicamente la concentración de imidazol, que fue de 50 mM para ScRad52 y de 100 mM para Cre.

Finalmente, las proteínas fueron eluídas en tres porciones de $1 \mathrm{~mL}$ cada una, con tampón de elución (20 mM Tris-HCl. pH=7,9 / 500 mM NaCl / 500 mM Imidazol), permitiendo que éste actuara durante 15 minutos antes de recoger cada fracción eluída. Todas las fracciones fueron recogidas en un mismo tubo, y posteriormente pasadas por columnas PD-10 para intercambiar el tampón de elución por un tampón de glicerol (50\% glicerol / 500 mM NaCl / 20 mM HEPES).

Por último, ambas proteínas fueron concentradas mediante la utilización de columnas Amicon ${ }^{\circledR}$ Ultra, según indicaciones del fabricante. Estas columnas retienen proteínas 
mayores a $10 \mathrm{kDa}$. Una vez realizado esto, se midió la concentración de ambas proteínas mediante método colorimétrico utilizando el kit RC DC protein assay. La pureza fue, además, estimada mediante electroforesis en gel de poliacrilamida.

\subsubsection{SDS-PAGE y Western Blot.}

Ambas proteínas fueron sometidas a electroforesis en gel de poliacrilamida, según se detalló en esta sección en el apartado 2.1.7. Para ello, se han utilizado geles al $8 \%$ de acrilamida para Cre recombinasa, y al 10\% de acrilamida para ScRad52. Con ambas proteínas se ha realizado tanto tinción con azul de Coomassie como western blot.

Para ambas proteínas hemos utilizado un anticuerpo primario monoclonal de ratón $\alpha$ polyHistidine, a una dilución 1:2000 durante 60 minutos. El anticuerpo secundario utilizado fue un $\alpha-\lg G$ de ratón marcado con peroxidasa de rábano, a una dilución 1:5000 durante 30 minutos.

La película fotográfica y la membrana fueron enfrentadas a diferentes tiempos, encontrándose que para estas proteínas el tiempo óptimo fue de 30 segundos.

\subsection{Línea celular reportera HCT116-RCL.}

\subsubsection{Diseño y construcción de un vector reportero MCS- $\triangle 3$ - EGFPtrunc-vector.}

Para la construcción del vector necesario para crear la célula reportera se amplificaron por PCR tres fragmentos génicos, utilizando en todos los casos la enzima Phusion Hot Start High-Fidelity DNA Polymerase (Thermo Scientific). Al finalizar cada una de las PCRs, las muestras fueron sometidas a una electroforesis en gel de agarosa al $1 \%$, tras lo cual, las bandas obtenidas se cortaron y purificaron en columnas.

1. Tomando como DNA molde el plásmido comercial de Addgene pAAV-CAGGSEGFP, 22.212, se ha realizado la primera PCR para la obtención del brazo 1 (Arm1, $1.9 \mathrm{~kb})$, que contiene una secuencia homóloga al sitio AAVS1 seguida de un casete de resistencia a puromicina. Este casete está formado por la secuencia SA-2A-Puro-PolyA, donde, SA es un aceptor de empalme (splice acceptor) que se incluye debido a que el sitio AAVS1 está en un intrón y $2 A$ es un péptido cuya secuencia interrumpe el enlace peptídico normal lo que lleva a saltarse el ribosoma 1. Esta secuencia se encuentra en el extreme $5^{\prime}$ del gen con el fin de garantizar que se produce una proteína independiente. Luego, se encuentra el gen de 
resistencia a puromicina $y$, finalmente, un polyA que protege el mRNA de la degradación, necesario para la terminación de la transcripción y para la exportación del mRNA desde el núcleo. La puromicina fue utilizada como antibiótico de selección para aquellas células que incorporaron el inserto. Esta PCR se ha llevado a cabo utilizando la pareja de primers RCL A1 S y RCL A1 AS. Las condiciones utilizadas para esta reacción fueron: 1 ciclo de 1 minuto a $98^{\circ} \mathrm{C}$; 40 ciclos de [ 15 segundos a $98^{\circ} \mathrm{C}, 20$ segundos a $62^{\circ} \mathrm{C}$ y 90 segundos a $72^{\circ} \mathrm{C}$; $\mathrm{y}$, finalmente, 1 ciclo de 5 minutos a $72^{\circ} \mathrm{C}$.

2. La siguiente $P C R$ se realizó para obtener el brazo 2 (Arm2, $1.3 \mathrm{~kb})$, esta utiliza como DNA molde el plásmido comercial pEGFP-C1. A partir de este se ha obtenido un fragmento de EGFP, el cual carece de los últimos $73 \mathrm{bp}$ en el extremo 3. Los primers que se utilizaron en este caso fueron el RCL A2 S y el RCL A2 AS, y las condiciones: 1 ciclo de 1 minuto a $98^{\circ} \mathrm{C} ; 40$ ciclos de $\left[15\right.$ segundos a $98^{\circ} \mathrm{C}, 20$ segundos a $60^{\circ} \mathrm{C}$ y 90 segundos a $72^{\circ} \mathrm{C}$; y, por último, 1 ciclo de 5 minutos a $72^{\circ} \mathrm{C}$.

3. Por último, para obtener el brazo $3(A r m 3,1.3 \mathrm{~kb})$ cuya secuencia será homóloga a la que existe en el sitios AAVS1, en el intrón 1 del cromosoma 19, se utilizó como molde el DNA genómico de células HCT-116. Los primers utilizados en esta reacción fueron el RCL A3 S y el RCL A3 AS, bajo las siguientes condiciones: 1 ciclo de 1 minuto a $98^{\circ} \mathrm{C} ; 40$ ciclos de $\left[15\right.$ segundos a $98^{\circ} \mathrm{C}, 20$ segundos a $62^{\circ} \mathrm{C}$ y 90 segundos a $72^{\circ} \mathrm{C}$; $y$, en última instancia, 1 ciclo de 5 minutos a $72^{\circ} \mathrm{C}$.

Una vez finalizada cada una de las PCRs precedentes, éstas se corrieron en gel de agarosa al $1 \%$, tras lo cual se cortaron y purificaron las bandas correspondientes a cada uno de los brazos. Una vez realizado esto, las muestras fueron sometidas a digestión con las enzimas de restricción correspondientes, cuyos sitios fueron incluidos en los primers, y generar así fragmentos de extremos adhesivos para su posterior ligación. El brazo 1 ha sido digerido con Notl/Sall, el brazo 2 con Sall/EcoRI y el brazo 3 con EcoRI/Notl. Las digestiones se llevaron a cabo a $37^{\circ} \mathrm{C}$ durante una hora, tras lo cual han sido purificadas nuevamente con columnas, y cuantificadas mediante NanoDrop. Los fragmentos así obtenidos fueron, posteriormente, insertados en el vector de clonación pAAV-MCS $(4.6 \mathrm{~kb})$, el cual fue previamente digerido con Notl y desfosforilado con SAP para evitar su posterior autoligación. La digestión del vector pAAV-MCS con Notl da lugar a un fragmento de $2.9 \mathrm{~kb}$ que contiene en ambos extremos las secuencias ITRs. 
Los tres fragmentos (Arm1, Arm2 y Arm3) fueron ligados utilizando el kit de ligación y, posteriormente, se transformaron bacterias XL-10 gold, sembrándose en placas de LB agar con ampicilina, e incubando durante 16 horas a $37^{\circ} \mathrm{C}$.

Transcurrido este tiempo se tomaron algunas de las colonias resistentes a ampicilina las cuales se sembraron en LB líquido con ampicilina en agitación a $37^{\circ} \mathrm{C}$ y $250 \mathrm{rpm}$ durante 16-20 horas. Pasado el tiempo de incubación se realizaron minipreps de las muestras y, posteriormente, las digestiones de comprobación con Notl, Notl/Sall, Sall/EcoRI y Notl/EcoRI.

Una vez obtenida una colonia positiva para la incorporación del constructo correcto, se realizó el correspondiente midiprep.

El vector así obtenido, se ha denominado MCS- $\Delta 3$-EGFPtrunc-vector.

\subsubsection{Diseño y construcción de un vector donante MCS- $\triangle 5$ - EGFP-donor.}

El vector donante, con el que se produjeron viriones rAAV, se realizó siguiendo una estrategia similar a la del vector reportero. Las PCRs realizadas en este caso fueron las siguientes.

1. La PCR para obtener el brazo 1 (Arm1, $1 \mathrm{~kb})$, se realizó utilizando como DNA molde el plásmido comercial pEGFP-N1, a partir del cual se obtuvo un fragmento de EGFP en el cual se han eliminado los primeros $38 \mathrm{bp}$ en el extremo $5^{\prime} \mathrm{y}$, por tanto, es incapaz de expresar la proteína fluorescente. Los primers que se utilizaron en este caso fueron el RCL B1 $S$ y el RCL B1 AS, y las condiciones utilizadas: 1 ciclo de 1 minuto a $98^{\circ} \mathrm{C}$; 40 ciclos de [15 segundos a $98^{\circ} \mathrm{C}, 20$ segundos a $62^{\circ} \mathrm{C}$ y 90 segundos a $72^{\circ} \mathrm{C}$; y, finalmente, 1 ciclo de 5 minutos a $72^{\circ}$ C.

2. El brazo de homología 2 (Arm2, $1.6 \mathrm{~kb}$ ), en cambio, se obtuvo mediante digestión del plásmido pBS-Blasticidin con las enzimas Sall/EcoRI, durante 1 hora a $37^{\circ} \mathrm{C}$. Este plásmido contiene un casete de resistencia a blasticidina, el cual fue utilizado como antibiótico de selección para aquellas células que incorporaron el rAAV.

3. El brazo de homología $3(A r m 3,1.9 \mathrm{~kb})$, es el mismo Arm3 utilizado en la construcción del vector MCS- $\Delta 3$-EGFPtrunc-vector.

Una vez finalizada la PCR del brazo 1, esta fue sometida a una electroforesis en gel de agarosa al $1 \%$. La banda obtenida se cortó y purificó y por último, fue digerida con 
PspOMI/Sall durante 60 minutos a $37^{\circ} \mathrm{C}$. Transcurrido este tiempo, se purificó nuevamente y luego se cuantificó utilizando el NanoDrop.

Tras la digestión del pBS-Blasticidin, la banda de 1.6 kb también se aisló del gel y luego se purificó y cuantificó.

De la misma manera que anteriormente, estos dos fragmentos se ligaron, junto con el brazo 3 obtenido anteriormente, al vector pAAV-MCS digerido con Notl y desfosforilado con SAP. Una vez que las colonias bacterianas han crecido en LB agar con ampicilina y que se han realizado los minipreps, se llevaron a cabo las digestiones de comprobación. Tras comprobar que la ligación fue correcta, se realizaron los midipreps.

El vector obtenido aquí, es el MCS- $\Delta 5$-EGFP-donor.

\subsubsection{Generación de una línea celular reportera.}

En primera instancia, se eligieron como línea reportera las células HCT-116, ya que es conocido que en esta línea la recombinación homóloga es mayor que en otras líneas celulares. Esto, probablemente, se deba a que estas células tienen una mutación con pérdida de función en el gen MLH1, por lo tanto, la proteína codificada por este gen, que interviene en el sistema de reparación de desemparejamientos (mismatch repair system) no es expresada e, indirectamente, se ve aumentada la $\mathrm{RH}$ como mecanismo de reparación celular (Davis et al., 1998).

En paralelo, también realizamos la construcción de una línea celular reportera en células U2OS. Sin embargo, todos los experimentos que aquí se describen, se realizaron en la línea reportera generada en células HCT116.

En estas líneas debíamos de introducir el DNA exógeno que codifica para la EGFP truncada en el C-terminal (extremo 3'). Para dirigir la introducción de esta secuencia de manera específica, se han utilizado 2 mRNAs de ZFNs comerciales que reconocen específicamente la secuencia AAVS1 en el intrón 1, del cromosoma 19:

5' - ACCCCACAGTGG ggccac TAGGGACAGGAT - 3’.

Los primeros 12 bp corresponden al dominio de unión de la ZFN 5' (o ZFN izquierda), mientras que los últimos 12 bp corresponden al dominio de unión de la ZFN 3' (o ZFN derecha). Las 6 bp intermedias corresponden al espacio entre los dos sitios de reconocimiento de las ZFNs, sobre el cual los dominios Fokl han de dimerizar y escindir así el DNA, produciendo el corte de la doble hebra. 
En $1,5 \times 10^{6}$ células HCT-116 en D-MEM completo se realizó una nucleofección mediante la utilización del Amaxa ${ }^{\circledR}$ Cell Line Nucleofector ${ }^{\circledR}$ Kit $V$, siguiendo instrucciones del fabricante, y utilizando $10 \mu \mathrm{g}$ del vector reportero, obtenido anteriormente, junto con un tubo de $10 \mu \mathrm{L}$ de ZFN mRNA-AAVS1 (0.6 $\mu \mathrm{g} / \mu \mathrm{L})$, perteneciente al kit CompoZr ${ }^{\circledR}$ Targeted Integration Kit - AAVS1.

Después de 48 horas, se tripsinizaron las células y se distribuyeron en dos placas de 96 pocillos, para realizar la selección clonal. En ambas placas se añadió, como antibiótico de selección, puromicina a una concentración de $1 \mu \mathrm{g} / \mathrm{mL}$.

Aproximadamente 10 días después de haber distribuido las células en las placas de 96, crecieron clonas de un tamaño suficiente como para realizar el screening por PCR. Para ello, se extrajo el DNA de todas las clonas que alcanzaron un tamaño suficiente, según se explicó en el apartado 2.1.6 de esta misma sección. Las PCRs se llevaron a cabo utilizando los primers: RCLS1 S y RCLS1 AS, para comprobar la inserción del brazo 1, y RCLS2 S y RCLS2 AS, para el brazo 3.

En la PCR de comprobación de la inserción del brazo 1, se utilizó la DNA polimerasa iStar, con las siguientes condiciones de reacción: 1 ciclo de 2 minutos a $95^{\circ} \mathrm{C} ; 40$ ciclos de [20 segundos a $95^{\circ} \mathrm{C}, 20$ segundos a $58^{\circ} \mathrm{C}$ y 80 segundos a $72^{\circ} \mathrm{C}$ ]; y, por último, 1 ciclo de 5 minutos a $72^{\circ} \mathrm{C}$.

En la PCR de comprobación de la inserción del brazo 3, en cambio, se ha utilizado la enzima Phusion Hot Start con su tampón GC, y las condiciones fueron: 1 ciclo de 1 minuto a $98^{\circ} \mathrm{C} ; 40$ ciclos de $\left[15\right.$ segundos a $98^{\circ} \mathrm{C}, 20$ segundos a $51^{\circ} \mathrm{C}$ y 105 segundos a $72^{\circ} \mathrm{C}$; $y$, finalmente, 1 ciclo de 5 minutos a $72^{\circ} \mathrm{C}$.

Estas reacciones fueron, luego, sometidas a una electroforesis en gel de agarosa al $1 \%$.

Una vez obtenidos los resultados de ambas reacciones de PCR, se eligieron 12 clonas que incorporaron correctamente el inserto con la EGFP mutada, obtenidas por dilución límite, sobre las cuales se comprobaría posteriormente la eficacia de la línea celular frente al virus donante.

\subsubsection{Obtención del virus adenoasociado AAV- $\Delta 5$-EGFP- donor.}


En frascos de cultivo de $75 \mathrm{~cm}^{2}$, se cultivaron células AAV293 en medio DMEM completo con antibiótico a $37^{\circ} \mathrm{C}$ y $5 \%$ de $\mathrm{CO}_{2}$, hasta que las células alcanzaron una confluencia de, aproximadamente, el $80 \%$.

Media hora antes de realizar la transfección, el medio de cultivo se cambió por $12 \mathrm{~mL}$ de DMEM suplementado, libre de antibióticos, y se dejó incubando en las condiciones ya mencionadas anteriormente.

La transfección se realizó empleando el método del fosfato de calcio de la siguiente manera (figura 12): en un tubo estéril de $15 \mathrm{~mL}$ se mezclaron los plásmidos MCS- $\Delta 5$ EGFP-donor, pAAV-RC y pAAV-helper, usando $9 \mu \mathrm{g}$ de cada uno, junto con 111,6 $\mu \mathrm{L}$ de fosfato de calcio $2 \mathrm{M}$, llevando a un volumen final de $900 \mu \mathrm{L}$ con agua estéril (provista por el kit). Luego, en otro tubo con $900 \mu \mathrm{L}$ de $2 x H B S$, se fueron añadiendo en el centro de la solución, gota a gota, la mezcla que contiene los plásmidos y el fosfato de calcio. Esta mezcla se incubó durante 10 minutos a temperatura ambiente. Pasado este tiempo, la solución se añadió al cultivo de células AAV293, agitando la placa para permitir que los complejos se distribuyeran uniformemente. Las células transfectadas se incubaron en una atmósfera de $5 \%$ de $\mathrm{CO}_{2}$ a $37^{\circ} \mathrm{C}$. Al día siguiente, el medio se reemplazó con DMEM fresco con antibiótico y se continuó con la incubación en las mismas condiciones descritas durante 48 horas más.

A los 3 días de haber realizado la transfección se pasaron las células, mediante raspado de la superficie, a tubos falcon que se centrifugaron a $4^{\circ} \mathrm{C}, 1.100 \mathrm{rpm}$ y durante 5 minutos. Este pellet fue lavado con PBS dos veces y luego resuspendido en $1.5 \mathrm{~mL}$ de DMEM suplementado. Las células se lisaron mediante cuatro ciclos de congelación/descongelación, incubando durante 10 minutos en baño de hielo seco con etanol, seguido de incubación en baño a $37^{\circ} \mathrm{C}$ durante otros 10 minutos.

Finalmente, la suspensión se centrifugó a $12.000 \mathrm{rpm}$ durante 5 minutos a $4^{\circ} \mathrm{C}$. El sobrenadante así obtenido, contiene la solución viral primaria, la cual se almacenó a $80^{\circ} \mathrm{C}$ para su posterior titulación. 


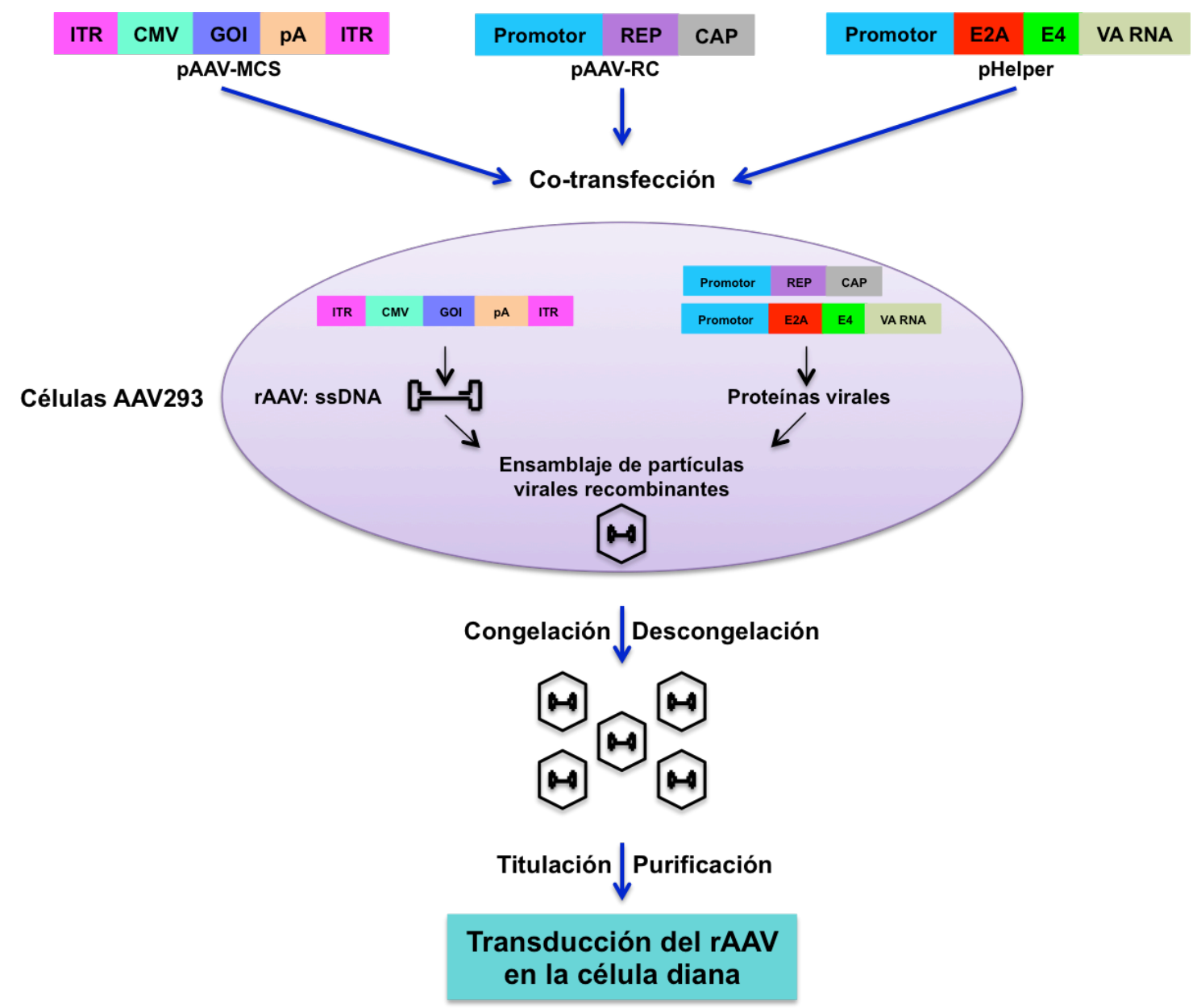

Figura 12. Esquema de la producción de rAAVs. Co-transfección de los plásmidos pAAV-MCS, pAAV-RC y pHelper y obtención de partículas virales recombinantes.

\subsubsection{Cuantificación del título adenoviral.}

Antes de almacenar el rAAV obtenido a $-80^{\circ} \mathrm{C}$, se tomó una alícuota de $20 \mu \mathrm{L}$, con la cual se realizaron diluciones seriadas (1/10 con tampón TE $1 \mathrm{X})$ que se utilizaron para calcular el título viral.

Los volúmenes de reacción utilizados para realizar la qPCR en LightCycler® 480 (Roche), fueron: $12.5 \mu \mathrm{L}$ de SYBR Green I Master $+1.5 \mu \mathrm{L}$ primer ITR S $(10 \mu \mathrm{M})+1.5$ $\mu \mathrm{L}$ primer ITR AS $(10 \mu \mathrm{M})+5 \mu \mathrm{L}$ de DNA, en un volumen total de $25 \mu \mathrm{L}$.

Los primers utilizados para realizar la titulación, el ITR S y el ITR AS (Aurnhammer et al., 2012), permiten amplificar un fragmento de 62 pares de bases. Estos se encuentran dentro de las regiones ITRs, lo cual hace factible la comparación entre las diferentes muestras y una curva patrón, realizada con el plásmido pAAV-MCS, ya que estas ITRs, son regiones constantes en todos los AAV. 
Las condiciones utilizadas para la llevar a cabo la qPCR, son las siguientes: desnaturalización, 1 ciclo de 10 minutos a $95^{\circ} \mathrm{C}$; PCR: 35 ciclos de $[15$ segundos a $95^{\circ} \mathrm{C}, 15$ segundos a $60^{\circ} \mathrm{C}, 20$ segundos a $72^{\circ} \mathrm{C}$ ]; curva de melting 1 ciclo de [ 1 minuto a $65^{\circ} \mathrm{C}, 1$ minuto a $35^{\circ} \mathrm{C}, 1$ segundo a $65^{\circ} \mathrm{C}$ y $95^{\circ} \mathrm{C}$ continuo], y por último, enfriamiento, 1 ciclo de 30 segundos a $40^{\circ} \mathrm{C}$.

Como se ha mencionado anteriormente, en paralelo a la cuantificación del rAAV se ha realizado un curva patrón. Conociendo el tamaño y la concentración del plásmido pAAV-MCS, hemos calculado el número de copias de cada una de las diluciones de la curva patrón. Las diluciones van desde $10^{3}$ copias $/ \mu \mathrm{L}$ a $10^{10}$ copias $/ \mu \mathrm{L}$.

El número de partículas ya está ajustado según el número de ITRs, ya que el plásmido contiene 4 ITRs, mientras que el virus sólo contiene dos, por lo cual el número obtenido es directamente la concentración viral en la solución.

Todas las muestras utilizadas en la RT-PCR se analizaron por triplicado.

Una vez finalizada la reacción, realizamos los análisis correspondientes con el software de análisis del LightCycler® 480 (Roche) para obtener una recta patrón a partir de los valores estándar así como los valores de título viral. El análisis de las curvas de disociación (o melting curves, en inglés) nos permitió comprobar la especificidad de las reacciones de amplificación.

\subsubsection{Diseño y construcción de TALENs.}

Mediante el kit de Addgene LIC TAL Effector Assembly (Schmid-Burgk et al., 2013), de Addgene, se construyó una pareja de TALENs que reconocen una secuencia específica del genoma de nuestra línea celular reportera (figura 13).

Para ello primero se diseñaron las TALENs, analizando la secuencia de interés en el programa que se encuentra en la página de libre acceso de internet: http://emboss.bioinformatics.nl/cgi-bin/emboss/fuzznuc, haciendo uso del patrón T$\mathrm{N}(51,54)-A$, que nuestra pareja de TALENs debe cumplir. Una vez que el programa proporcionó una secuencia acorde a nuestros requerimientos, introdujimos la nueva secuencia en otro programa de libre acceso de internet: http://www.hornunglab.de/Tassembly.html. Este último nos proporcionó, finalmente, la secuencia que debíamos de utilizar según los plásmidos 2-mer necesarios y el orden en que debían asociarse, como así también, el tipo de BBL2 (plásmidos de segundo nivel) que debía de usarse para la construcción final de ambas TALENs. En nuestro caso, la secuencia final fue: 
TGCCAGAACCTCTAAGGTTT gcttacgatggagcc AGAGAGGATCCTGGGAGGGA.

Las secuencias en mayúsculas, corresponden a cada uno de los dominios de unión a DNA de cada una de las TALENs, mientras que la secuencia en minúsculas corresponde al espaciador, una secuencia que se encuentra en el genoma de la línea celular, y que corresponde al sitio donde actúa la Fokl produciendo el corte del DNA. En ambas TALENs, el plásmido de nivel 2 será el BB-L2-T.

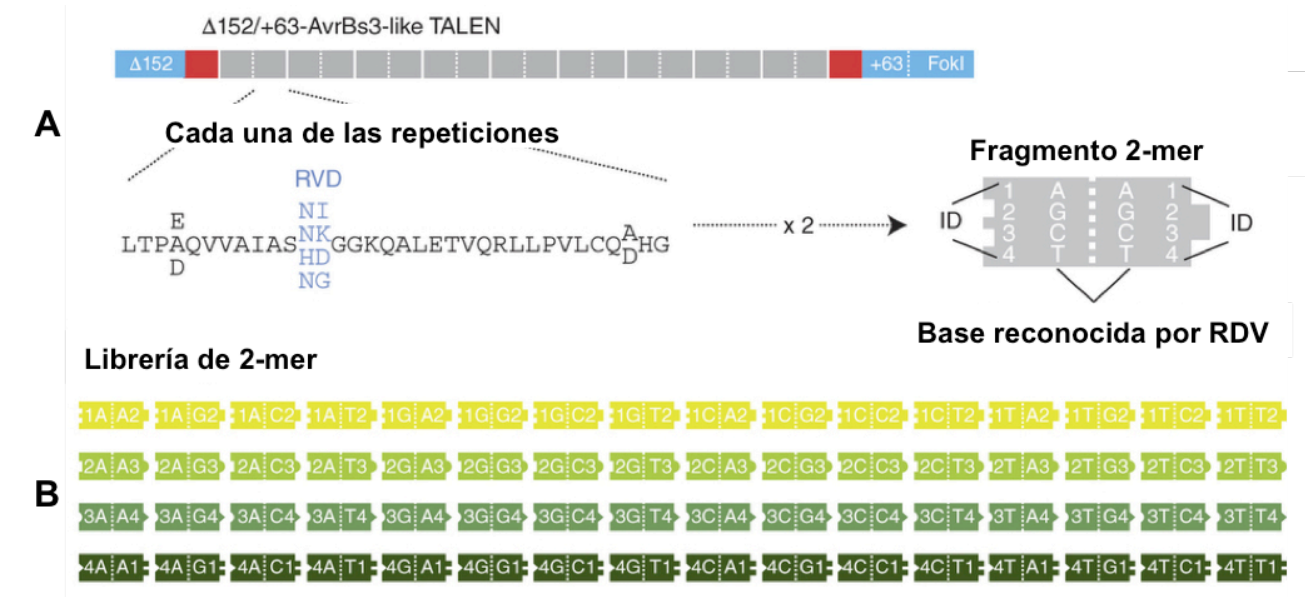

Ensamblaje de los 6-mer

C
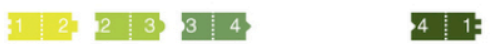

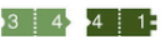

Ligación de los fragmentos 6-mer en los plásmidos de nivel 1 (BBL1)

D

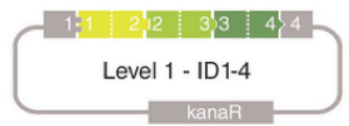

Ensamblaje de los 18-mer

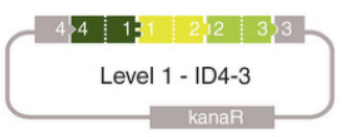

\begin{tabular}{l:l:l:l|}
4 & 1 & 2 & 3 \\
4
\end{tabular}
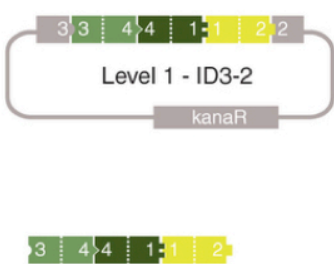

Ligación de los fragmentos 18-mer en los plásmidos de nivel 2 (BBL2)

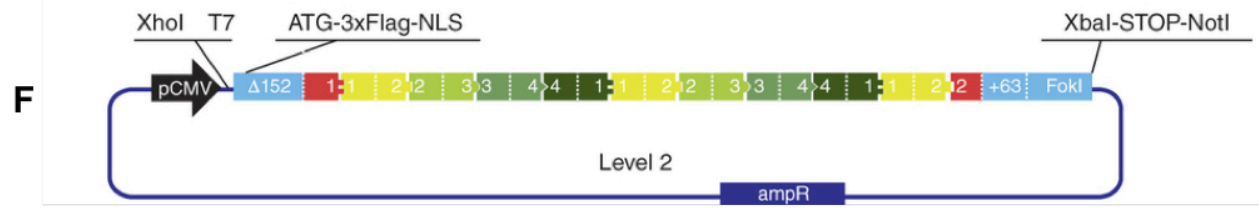

TALEN lista para su expresión

Figura 13. En la figura se observa la generación de TALENs por el método de LIC TAL Effector Assembly. A. Arquitectura de la TALEN, que contiene un extremo $\mathrm{N}$-terminal truncado, un dominio de reconocimiento invariable para timina, seguido de un tramo de varias unidades repetidas, y un extremo C-terminal también truncado, fusionado a un dominio de Fokl. También se observa una de las repeticiones con sus 34 aminoácidos y los residuos divariables (RDV) en las posiciones 12 y 13. A la derecha, un modelo de una unidad de clonación mínima, que consta de dos unidades de repetición consecutivos. B. Librería de plásmidos 2-mer. C, D. Tres 2-mers son ensamblados para generar un complejo de seis repeticiones en tándem, en un plásmido de nivel 1 (BBL1) con resistencia a kanamicina. $E$, $F$. Ensamblaje del fragmento completo de una TAL, ensamblando tres 6-mers en el plásmido de nivel 2 (BBL2), que contiene las variaciones anteriormente mencionadas, con la Fokl en el extremo C-terminal. pCMV, promotor del citomegalovirus; ampR, gen de resistencia bacteriana a ampicilina; NLS, señal de localización nuclear; ATG, codón de iniciación; STOP, codón de detención; T7, secuencia del promotor para la T7 RNA polimerasa; Xhol, Xbal y Notl son sitios de reconocimientos para dichas enzimas de restricción. Figura tomada y modificada de Schmid-Burgk et al., 2013. 
Antes de comenzar la construcción del par de TALENs, disponíamos de una librería de plásmidos, comercializada por Addgene, que contiene todas las combinaciones posibles de 2-MER (plásmidos que luego formarán parte del dominio modular de las TALENs, dos nucleótidos en el DNA diana). De esta manera, se podrán reconocer todas las posibles combinaciones de nucleótidos, por pareja. Dentro de esta librería, contamos también con los plásmidos BB-L1 (plásmidos de nivel 1) y BB-L2 (plásmidos de nivel 2), los cuales se utilizarán en lo sucesivos pasos para construcción de la pareja final de TALENs.

El primer paso realizado, fue el de las digestiones. Para cada 2-mer se han realizado digestiones con la enzima Mva1269l, y para linearizar los plásmidos de nivel 1 (BB-L1) se ha hecho una digestión doble con Pstl/Kpnl, según se indica en el protocolo. Todas las digestiones se llevaron a cabo a $37^{\circ} \mathrm{C}$, durante 1 hora. Al finalizar este tiempo, aquellas correspondientes a los 2 -mer se han puesto 5 minutos a $65^{\circ} \mathrm{C}$ para inactivar la enzima, mientras que las de los BB-L1 se sometieron a una electroforesis en gel de agarosa al $1 \%$, tras lo cual se han cortado las bandas de $2.7 \mathrm{~kb}$ para cada plásmido, y se han purificado en columna.

El siguiente paso realizado ha sido el chew-back, que consiste en la digestión parcial de una de las hebras de la doble cadena de DNA. Para ello, se utilizan dATP y dTTP junto con la enzima T4 DNA polimerasa, la cual además de catalizar la síntesis de DNA en sentido $5^{\prime} \rightarrow 3^{\prime}$, también posee actividad $3^{\prime} \rightarrow 5^{\prime}$ exonucleasa. Este método utiliza la actividad exonucleasa $3^{\prime} \rightarrow 5^{\prime}$ de la enzima T4 polimerasa y genera extremos protruyentes. Para controlar el tamaño de los extremos protruyentes se añadió a la reacción un determinado dNTP STOP (en nuestro caso dATP o dTTP) para competir con la actividad DNA polimerasa y así frenar la actividad exonucleasa.

La reacción de chew-back se realizó siguiendo las indicaciones del protocolo, utilizando los dNTPs correspondientes según el 2-mer y el BB-L1:

- 2-mer ID 1-2, 2-mer ID 3-4 y BB-L1 ID 4-3: dATP

- 2-mer ID 2-3, 2-mer ID 4-1, BB-L1 ID 1-4 y BB-L1 ID 3-2: dTTP

Al finalizar la reacción, se diluyó cada 2-MER y cada BB-L1 utilizando el tampón 2 de New England Biolabs, y se procedió a realizar la mezcla para que se produzca la autoligación de los 3 fragmentos obtenidos a partir de los 2-MERs y el BB-L1. Para este paso, también se siguieron las indicaciones del protocolo. Al final de la incubación, se transformaron $3 \mu \mathrm{L}$ en bacterias $\mathrm{XL}-10$, en placas de LB-agar con kanamicina 30 $\mu \mathrm{g} / \mathrm{mL}$, y se incubaron durante 16 horas a $37^{\circ} \mathrm{C}$. 
Al día siguiente se picaron las colonias obtenidas, se incubaron 16 horas a $37^{\circ} \mathrm{C}$ y se realizaron los minipreps que luego se analizaron mediante digestión con Mva1269I. Las colonias buenas fueron aquellas en las que se obtuvieron dos bandas al correr en gel de agarosa, una de $2.7 \mathrm{~kb}$ y otra de alrededor de $0.7 \mathrm{~kb}$ (según los 2-MERs que intervienen en la reacción).

En paralelo, se realizó la digestión de los BB-L2 utilizando la enzima Kpnl Posteriormente se purificó la banda correspondiente al plásmido linearizado luego de someter la muestra a una electroforesis en gel de agarosa.

De la misma manera que se ha hecho anteriormente, se realizó el chew-back de los 6MERs y también de los BB-L2, para luego diluirlos, ligarlos y transformarlos en XL-10, pero a diferencia del paso anterior, esta vez se utilizaron placas de LB-agar con ampicilina. Nuevamente se incubaron por 16 horas, y se sembraron las colonias obtenidas en LB líquido, incubándose durante otras 16 horas para luego, realizar los minipreps y analizarlos mediante digestión con Xbal/Xhol. Al correr en gel de agarosa al $1 \%$, se comprobó si se obtuvieron las bandas de $5.5 \mathrm{~kb}$ y $3.3 \mathrm{~kb}$ que corresponden a las dos TALENs esperadas.

\subsubsection{Funcionalidad in vitro de las TALENs en la RCL.}

Para comprobar el funcionamiento de las TALENs, se realizó la transfección de las mismas junto con un DNA donante para favorecer así, la recombinación homóloga.

Veinticuatro horas antes de la transfección se sembraron 15.000 células HCT116$\mathrm{RCL}$, en cada pocillo de una placa de 96. El día de la transfección se cambió el medio a las células añadiendo $100 \mu \mathrm{L}$ de medio suplementado sin antibiótico, y realizando la transfección con $0.6 \mu \mathrm{L}$ de TransIT-X2 con 200 ng de cada uno de los plásmidos de TALENs 1 y 2 . Todo esto se realizó en un volumen final de $50 \mu \mathrm{L}$ utilizando Opti-MEM. Transcurridas 6 horas de la transfección, se retiró el medio que contenía las TALENs, y se añadieron $100 \mu \mathrm{L}$ de Opti-MEM sobre los cuales se añadió el virus donante AAV- $\triangle 5$-EGFP-donor $\left(10^{3} \mathrm{MOI}\right.$, Multiplicidad de infección o número de genomas virales que infecta una célula). Tras 24 horas de incubación se cambió el medio por medio completo con antibiótico y se esperó entre 48 y 72 horas para ver la expresión de la proteína fluorescente verde, lo cual indicaría que ha ocurrido recombinación homóloga entre el vector donante y la célula reportera. 


\subsubsection{ScRad52. Cambios en la frecuencia de recombinación homóloga.}

Con el fin de comprobar la funcionalidad de la proteína obtenida anteriormente, en condiciones in vitro, hemos realizado diferentes experimentos, definiendo las siguientes condiciones de reacción.

Dos días antes de realizar el experimento se sembraron 15.000 células HCT116-RCL. El día del experimento se cambió el medio completo en el cual se encontraban las células por Opti-MEM, medio sobre el cual se realizó la transfección, utilizándose 200 $\mu \mathrm{g}$ de cada una de las TALENs con $0.6 \mu \mathrm{L}$ detransIT-X2 como reactivo de transfección. Este medio se dejó incubando durante 5 horas, tras lo cual fue cambiado por Opti-MEM. Sobre el Opti-MEM se añadieron diferentes cantidades de ScRad52: $0.025 \mu \mathrm{g}, 0.5 \mu \mathrm{g}, 1 \mu \mathrm{g}, 5 \mu \mathrm{g}, 10 \mu \mathrm{g}$ y $12.5 \mu \mathrm{g}$. Una hora más tarde se retiró la proteína y se procedió a realizar la transducción de las células con el AAV- $\Delta 5$-EGFP-donor $\left(10^{3}\right.$ $\mathrm{MOI})$. Entre dos y tres días posteriores a la transducción, ya se pudieron observar las células verdes.

\subsubsection{Librería de siRnAs. Cambios en la frecuencia de recombinación homóloga.}

Con objeto de ensayar métodos que aumenten la frecuencia de recombinación homóloga hemos utilizado una librería de RNAs pequeños de interferencias, también conocidos como siRNAs (Adamson et al., 2012. Słabicki et al., 2010). En el anexo se presentan la información de cada siRNA utilizado: gen al que silencian, exón sobre el cual ejercen su acción, secuencia, casa comercial y tipo de siRNA.

Los siRNAs normales se han transfectado a una concentración final de $40 \mathrm{nM}$ y los silencer select siRNAs a $5 \mathrm{nM}$, ambos en un volumen final de $170 \mu \mathrm{L}$ para cada pocillo de una placa de 96.

Veinticuatro horas antes de la transfección se sembraron 10.000 células HCT116$\mathrm{RCL}$, en una placa de 96 pocillos. El día de la transfección se añadieron $100 \mu \mathrm{L}$ de medio suplementado sin antibiótico, y luego, la transfección se hizo con la cantidad correspondiente de cada siRNA, más $0.6 \mu \mathrm{L}$ de TransIT-X2, todo en un volumen final de $70 \mu \mathrm{L}$ de Opti-MEM.

Esto se dejó incubando 24 horas a $37^{\circ} \mathrm{C}$ y $5 \% \mathrm{CO}_{2}$, tras lo cual se cambió el medio por $120 \mu \mathrm{L}$ de medio suplementado sin antibiótico. Sobre este medio se realizó la 
transfección de las TALENs cambiando a las 6 horas el medio por Opti-MEM sobre el cual se realizó la infección con AAV- $\Delta 5$-EGFP-donor, de la misma manera que lo hemos hecho anteriormente. Al día siguiente se cambió el medio por medio suplementado con antibiótico.

A las 48-72 horas de transfectar las TALENs, ya se pueden observar las células que emiten luz verde fluorescente.

Una vez definidos aquellos siRNAs que causaron aumento en la frecuencia de $\mathrm{RH}$, se llevó a cabo el estudio del ciclo celular de los mismos. Para ello, se realizó el experimento sembrando 10.000 células 24 horas antes de la transfección, en placa de 96 pocillos. Posteriormente, se realizó la transfección de los siRNAs elegidos y se dejó 24 horas más. Transcurrido este tiempo, las células fueron tripsinizadas y posteriormente centrifugadas durante 5 minutos a $1.000 \mathrm{rpm}$. Se retiró el sobrenadante y se resuspendió el pellet en $1 \mathrm{~mL}$ de PBS $1 \mathrm{X}$. Se volvió a centrifugar 5 minutos a $1.000 \mathrm{rpm}$ tras lo cual, nuevamente, se eliminó el sobrenadante y se resuspendió en $1 \mathrm{~mL}$ de etanol $80 \%$. Las células así obtenidas se mantuvieron a $-20^{\circ} \mathrm{C}$ hasta su análisis por citometría de flujo. En el momento de realizar la lectura, la muestra se centrifugó 5 minutos a $1.000 \mathrm{rpm}$ y se resuspendió el pellet en $700 \mu \mathrm{L}$ de PBS 1X. Finalmente se añadieron yoduro de propidio (concentración final $5 \mathrm{mg} / \mathrm{mL}$ ), RNAsa (concentración final $10 \mathrm{mg} / \mathrm{mL}$ ) y Tritón X-100 (concentración final 0,1\%). Las muestras se incubaron durante 1 hora a $37^{\circ} \mathrm{C}$ en la oscuridad, tras lo cual se realizó el análisis del ciclo celular mediante citometría de flujo.

\subsection{Generación, corrección y transdiferenciación de la línea celular WASP-KO.}

\subsubsection{Diseño y construcción del vector p-AAV-MCS-WASP-KO mediante mutagénesis dirigida.}

Para la construcción de este vector se amplificó DNA genómico de fibroblastos humanos, utilizando la enzima Phusion Hot Start High-Fidelity DNA Polymerase, para obtener los brazos de homología.

EL brazo de homología 1 (Arm 1, $1.1 \mathrm{~kb}$ ), que contiene la secuencia correspondiente a los exones 3, 4, 5 y 6, se obtuvo mediante PCR utilizando los primers WASP A1 S y WASP A1 AS. Las condiciones empleadas fueron las siguientes: 1 ciclo de 1 minuto a $98^{\circ} \mathrm{C} ; 35$ ciclos de $\left[15\right.$ segundos a $98^{\circ}, 20$ segundos a $59^{\circ} \mathrm{C}$ y 45 segundos a $72^{\circ} \mathrm{C}$ ]; y, finalmente, 1 ciclo de 5 minutos a $72^{\circ} \mathrm{C}$. 
El brazo de homología 2 ( $A r m 2,1.5 \mathrm{~kb}$ ), que contiene la secuencia correspondiente al exón 7, se obtuvo haciendo uso de los primers WASP A2 S y WASP A2 AS. Las condiciones utilizadas para llevar a cabo la reacción fueron las siguientes: 1 ciclo de 1 minuto a $98^{\circ} \mathrm{C} ; 35$ ciclos de $\left[15\right.$ segundos a $98^{\circ}, 20$ segundos a $60^{\circ} \mathrm{C}$ y 55 segundos a $72^{\circ} \mathrm{C}$; y, finalmente, 1 ciclo de 5 minutos a $72^{\circ} \mathrm{C}$.

Al finalizar ambas PCRs, las mismas se sometieron a electroforesis en gel de agarosa al $1 \%$, a partir de la cual se cortaron y purificaron las bandas obtenidas. Posteriormente, estas muestras fueron sometidas a digestión con Notl/Sall para el brazo 1, y EcoRI/Notl para el brazo 2. Las digestiones se incubaron durante 60 minutos a $37^{\circ} \mathrm{C}$.

En paralelo, se digirió el vector pBS-Blasticidin con Sall/EcoRI en las mismas condiciones que las digestiones anteriores. Esto permitió obtener el casete de blasticidina $(1.6 \mathrm{~kb})$.

Las 3 muestras anteriores se sometieron a electroforesis en gel de agarosa, tras lo cual las bandas se cortaron, purificaron y cuantificaron mediante NanoDrop.

Posteriormente, subclonamos el brazo 1 obtenido anteriormente en el vector pBluescript II KS +/-. Para lo cual, ambos fragmentos fueron digeridos con Notl/Sall y posteriormente ligados y transformados en bacterias $\mathrm{DH} 5 \alpha$. Una vez obtenido este vector, se procedió a realizar una mutagénesis dirigida para incorporar así una mutación que corresponde a la inserción de una adenina en el exón 4, lo cual hace que se produzca un codón stop en la posición 168, dando lugar a la ausencia de expresión de WASp.

La mutagénesis dirigida de este nuevo plásmido, fue llevada a cabo utilizando el kit comercial QuickChange II, que utiliza como DNA molde el plásmido obtenido anteriormente, junto con los dos primers complementarios que contienen la mutación: R148X168ins S y R148X168ins AS. La reacción de amplificación se realizó en un volumen final de $50 \mu \mathrm{L}$, que contenían $1 \mathrm{X}$ del tampón de reacción (10X Reaction Buffer), $20 \mathrm{ng}$ de DNA, $25 \mathrm{ng}$ de primer $\mathrm{S}$ y $25 \mathrm{ng}$ de primer AS, $1 \mu \mathrm{L}$ de mezcla de dNTPs y $1 \mu \mathrm{L}$ de la enzima PfuUltra ${ }^{\mathrm{TM}}$ HF DNA polimerasa (PfuUltra ${ }^{\mathrm{TM}}$ HF DNA polymerase, 2,5 U/mL). Las condiciones de amplificación, en este caso, fueron: 1 ciclo de 30 segundos a $95^{\circ} \mathrm{C}$ y 16 ciclos de $\left[30\right.$ segundos a $95^{\circ} \mathrm{C}, 1$ minuto a $58^{\circ} \mathrm{C}$ y 6 minutos a $68^{\circ} \mathrm{C}$ ]. Una vez finalizada la reacción, el producto de amplificación, fue tratado con Dpnl $(10 \mathrm{U} / \mu \mathrm{L})$ durante 1 hora a $37^{\circ} \mathrm{C}$. Esta enzima tiene la función de digerir, específicamente, el DNA metilado del plásmido utilizado como molde y que, por tanto, no contiene la mutación. 
Posteriormente, se transformaron bacterias XL1-Blue supercompetentes (proporcionadas por el kit) con $1 \mu \mathrm{L}$ de la digestión, siguiendo el protocolo indicado en el apartado 2.1.1 de esta misma sección. Las bacterias transformadas fueron sembradas en placas de LB-agar con ampicilina, y luego, incubadas a $37^{\circ} \mathrm{C}$ durante 16 horas. Transcurrido este tiempo, se cultivaron las colonias que crecieron en la placa en LB líquido y se incubaron, nuevamente, en las condiciones anteriores. Por último se realizaron minipreps con columnas, y los plásmidos purificados se secuenciaron, utilizando el primer WASP A1 AS.

Una vez secuenciado el plásmido, el brazo 1 este fue digerido con Notl y Sall, y aislado a partir de un gel de agarosa al $1 \%$ y posteriormente purificado en columna. Una vez obtenidos los tres insertos, se procedió a realizar la ligación en el vector pAAV-MCS digerido con Notl y desfosforilado con SAP. Esta ligación fue posteriormente transformada en XL-10 gold y sembrada en placa de LB agar con ampicilina. Tras 16 horas a $37^{\circ} \mathrm{C}$ las colonias que crecieron en la placa se sembraron en LB líquido incubando, nuevamente, durante 16 horas a $37^{\circ} \mathrm{C}$. Con estas muestras se realizaron minipreps, y digestiones de control con Notl, Notl/Sall, Sall/EcoRI y EcoRI/Notl. Una vez que se obtuvo una colonia con el inserto ligado de manera correcta, se procedió a realizar un midiprep.

\subsubsection{Construcción del vector p-AAV-MCS-WASP-wt.}

Para la construcción del vector p-AAV-MCS-WASP-wt se casi siguió el mismo protocolo utilizado en el apartado anterior. Primero se realizaron las dos PCRs anteriormente mencionadas, junto con la digestión del vector pBS-Blasticidin con Sall/EcoRI. Una vez obtenidos los tres fragmentos a partir de un gel de agarosa al $1 \%$, estos fueron purificados por columna y posteriormente cuantificados, tras lo cual se procedió, directamente, a realizar la ligación en el vector $\mathrm{p}-\mathrm{AAV}$-MCS ya digerido con NotI/Sall. Esta ligación fue también utilizada para transformar bacterias XL-10 gold. Las colonias crecidas en la placa de LB agar con ampicilina, se sembraron luego en LB líquido con ampicilina, tras lo cual se realizaron minipreps. Una vez comprobados estos, por digestión, se realizaron midipreps de los mismos.

\subsubsection{Construcción de los virus AAV-WASP-KO y AAV-WASP-} wt. 
Los dos plásmidos obtenidos en las dos secciones anteriores se utilizaron para la construcción de virus adenoasociados, exactamente de la misma manera que se hizo en el apartado 2.3.4 de esta sección. Posteriormente, los mismos fueron cuantificados según se explicó, también en esta sección, en el apartado 2.3.5.

\subsubsection{Diseño y construcción de nickasas CRISPR/Cas9 para WASp.}

Para la construcción de las nickasas CRISPR/Cas9 se ha utilizado el protocolo de Ran et al., 2013. Para ello, lo primero que se hizo fue elegir el extremo $3^{\prime}$ del brazo 1 de los vectores anteriormente mencionados, como diana de las CRISPR nickasas. Para producir un corte en la doble hebra de DNA son necesarias dos nickasas: una reconoce una secuencia de 20 nucleótidos en el extremo $5^{\prime}$, mientras que la otra reconoce otra secuencia en el extremo $3^{\prime}$. Estas secuencias se encuentran separadas por 30 nucleótidos entre sí. Así, se diseñaron dos primers $S$ y dos AS complementarios para cada secuencia: CRISPR-WASP1 S y CRISPR-WASP1 AS, y, CRISPR-WASP2 S y CRISPR-WASP2 AS. La necesidad de utilizar ambas, se debe a que la nucleasa codificada por el plásmido pX335-U6-Chimeric_BB-CBh-hSpCas9m (D10A), al que a partir de ahora llamaremos solo pX335, es en realidad una nickasa que corta solo una de las cadenas del DNA, y en nuestro caso, queremos que el corte se produzca en ambas cadenas.

Posteriormente, se trataron $2 \mu \mathrm{g}$ del plásmido pX335 con la enzima Bbsl. La digestión se llevó a cabo durante 2 horas a $37^{\circ} \mathrm{C}$, tras lo cual la banda obtenida a partir de la electroforesis en gel de agarosa se cortó, purificó y cuantificó mediante NanoDrop.

Una vez finalizado el paso anterior, se procedió a realizar el anillamiento de los primers. Para ello se mezclaron $1 \mu \mathrm{L}$ de cada uno de los primers $\mathrm{S}$ y $\mathrm{AS}$ de cada pareja $(100 \mu \mathrm{M}), 5 \mu \mathrm{L}$ de $2 \mathrm{X}$ T4 ligase buffer (perteneciente al kit de ligación de Roche) y $1 \mu \mathrm{L}$ de T4 polinucleótido quinasa (PNK), todo esto en un volumen final de $10 \mu \mathrm{L}$. Esta reacción se llevó a cabo en termociclador, utilizando las siguiente condiciones: 1 ciclo de 30 minutos a $37^{\circ} \mathrm{C}, 1$ ciclo de 5 minutos a $95^{\circ} \mathrm{C}$ y, por último, una rampa de disminución de temperatura hasta $23^{\circ} \mathrm{C}$. Una vez finalizada la reacción, la muestra se diluyó 100 veces en $\mathrm{H}_{2} \mathrm{O}$.

El siguiente paso fue el de ligación. En este caso se han utilizado $100 \mathrm{ng}$ de vector y 2 $\mu \mathrm{L}$ de la dilución de la reacción de anillamiento. La ligación se realizó según se explicó en el apartado 2.1.4, y posteriormente, se tomaron $2 \mu \mathrm{L}$ que se utilizaron para 
transformar bacterias $\mathrm{DH} 5 \alpha$, las cuales se sembraron en placas de LB-agar con ampicilina y se incubaron durante 16 horas a $37^{\circ} \mathrm{C}$. Transcurrido este tiempo, las colonias que crecieron se sembraron en LB líquido con ampicilina y se incubaron, nuevamente, en iguales condiciones con agitación. Con estas muestras se realizaron minipreps que se digirieron durante 1 hora a $37^{\circ} \mathrm{C}$ con $\mathrm{Ndel}$ para comprobar la incorporación del inserto. De control, se utilizó el plásmido vacío. Finalmente, con las muestras positivas para la incorporación del inserto, se realizaron midipreps.

\subsubsection{Generación de líneas celulares WASP-KO.}

Para realizar una línea WASP-KO en fibroblastos primarios, lo primero que se hizo fue levantar las células del soporte en el cual se encontraban, mediante la utilización de tripsina y, luego, lavarlas con PBS. Una vez realizado este paso, se contaron 3 fracciones de $5 \times 10^{5}$ de células en cámara de Neubauer.

A la hora de realizar la nucleofección, lo primero que se hizo fue añadir en 3 pocillos de una placa de 6, 1,5 mL de medio completo de fibroblastos a cada uno. Esta placa se incubó durante todo el proceso a $37^{\circ} \mathrm{C}$ y $5 \%$ de $\mathrm{CO}_{2}$. En paralelo, las células ya contadas se centrifugaron a $200 x g$ durante 10 minutos a temperatura ambiente. Se retiró el sobrenadante, y el pellet se resuspendió en $100 \mu \mathrm{L}$ de solución de nucleofección suplementada (Nucleofector solution + supplement, en proporción 4,5:1). A la primera muestra se añadió siRNA para CREBBP $(5 \mathrm{nM})$, a la segunda siRNA para CREBBP + SFR1 (2,5 nM y 2,5 nM), y por último, a la tercera se añadió siRNA control ( $5 \mathrm{nM})$. Toda la mezcla se transfirió a una cubeta (provista por el kit), con cuidado de no pasar los 15 minutos antes de realizar la nucleofección, la cual se llevó a cabo utilizando el programa U-023 en busca de una mayor eficiencia de transfección. Una vez finalizada la nucleofección, se añadieron en la cubeta $500 \mu \mathrm{L}$ de medio completo de fibroblastos atemperado, e inmediatamente esto se transfirió a la placa que teníamos con medio incubando.

Transcurridas 24 horas se retiró el medio, se lavó dos veces con PBS y se añadieron $1,6 \mathrm{~mL}$ de OptiMEM y $40 \mu \mathrm{L}$ de AAV-WASP-KO (de título $10^{8}$ partículas $/ \mu \mathrm{L}$ ). Tras 24 horas, se quitó el medio en el cual se encontraba el virus y se añadió medio completo de fibroblastos.

Por otro lado, se realizó la modificación del gen WAS en células Jurkat mediante la utilización de CRISPR/Cas9. Para ello, nuevamente se ha utilizado la técnica de la nucleofección utilizada anteriormente, haciendo los siguientes cambios. Se utilizó 
medio completo normal. No se tripsinizaron las células, ya que estas son células en suspensión. El número de células utilizado en este caso fue el mismo que en el caso de los fibroblastos, $5 \times 10^{5}$. Se nucleofectaron los dos plásmidos correspondientes a las nickasas CRISPR, junto con un plásmido donante, el pAAV-MCS-WASP-KO. La cantidad nucleofectada de cada plásmido fue de $1 \mu \mathrm{g}$, y el programa utilzado el X-001.

A las 48 horas, tanto de haber infectado los fibroblastos, como de haber realizado la nucleofección en las Jurkat, las células fueron sembradas en placa de 96 pocillos y sobre ellas se añadió el antibiótico de selección, la blasticidina.

A partir de ahí, una vez que las células estuvieron lo suficientemente crecidas, se extrajo el DNA de diferentes muestras, y se realizaron PCRs para comprobar la inserción del DNA exógeno en el DNA genómico. Para ello se utilizaron los primers WASP S1.1 S, WASP S1.2 S y WASP S1 AS. Las condiciones utilizadas para llevar a cabo la PCR fueron las siguientes: 1 ciclo de 1 minuto a $98^{\circ} \mathrm{C} ; 40$ ciclos de $[15$ segundos a $98^{\circ} \mathrm{C}, 20$ segundos a $60^{\circ} \mathrm{C}, 75$ segundos a $72^{\circ} \mathrm{C}$ y, finalmente, 1 ciclo de 5 minutos a $72^{\circ} \mathrm{C}$. A partir de los resultados obtenidos, en aquellas muestras en que se haya obtenido la banda correspondiente al alelo modificado, se realizó dilución límite para asegurar monoclonalidad, tras lo cual volvieron a analizarse las clonas mediante PCRs, hasta obtener una clona pura de células WASP-KO.

Una vez obtenida una clona pura para Jurkat, realizamos un western-blot, según se explica en esta sección, en el apartado 2.1.9, para comprobar la ausencia de la proteína. Para ello utilizamos un anticuerpo primario policlonal $\alpha-W A S p$, denominado K-374, que reconoce los 16 aminoácidos C-terminales de WASp. En fibroblastos no es posible realizar un western blot, ya que los mismos no expresan la proteína.

\subsubsection{Tratamiento de células KO con CRE recombinasa.}

En este caso, se utilizaron fibroblastos WASp-KO, las cuales fueron previamente infectadas con AAV-WASP3456-KO, y mediante el cual adquirieron el casete de la blasticidina. Estas células fueron sembradas en placas de 24 pocillos, y el tratamiento con Cre recombinasa se realizó al alcanzar las mismas una confluencia del $80-90 \%$.

En primer lugar, las células fueron lavadas con PBS $1 \mathrm{X}$, dos veces. Luego se añadieron $150 \mu \mathrm{L}$ Opti-MEM y esto fue incubado a $37^{\circ} \mathrm{C}$ durante media hora. Una vez atemperadas las células, se agregó la Cre recombinasa obtenida en el laboratorio en una concentración final de $50 \mu \mathrm{g} / \mathrm{mL}$, y se incubó nuevamente la placa a $37^{\circ} \mathrm{C}$ durante 
1 hora. Transcurrido este tiempo, se añadió medio completo al pocillo que contenía las células con la proteína.

Al día siguiente se retiró el medio, se tripsinizaron las células y se hizo dilución límite en placa de 96 pocillos, con objeto de aislar clonas individuales. Cuando las clonas estuvieron lo suficientemente crecidas, se extrajo el DNA y se analizaron las clonas por PCR, utilizando un primer ubicado al comienzo de casete de blasticidina (WASP S1.1 S) y otro externo a la secuencia insertada en el extremo 3' (WASP S1 AS), con las siguientes condiciones: 1 ciclo de 1 minuto a $98^{\circ} \mathrm{C} ; 40$ ciclos de $[15$ segundos a $98^{\circ} \mathrm{C}, 20$ segundos a $60^{\circ} \mathrm{C}, 75$ segundos a $72^{\circ} \mathrm{C}$ y, finalmente, 1 ciclo de 5 minutos a $72^{\circ} \mathrm{C}$. Una vez finalizada la PCR, se sometieron las muestras amplificadas a una electroforesis en gel de agarosa al 1\% para verificar la deleción del casete de blasticidina.

\subsubsection{Corrección de la línea celular WASP-KO.}

Para intentar revertir la mutación introducida en los fibroblastos, se eligió aquella muestra en la que se verificó la deleción del casete de blasticidina. Esta fue posteriormente sometida a nucleofección, de la misma manera que se realizó en el apartado 2.4.5 de esta sección, haciendo uso del AAV-WASP-wt, y nucleofectando primero las células con la mezcla de siRNA (CREBBP + SFR1), 24 horas antes de realizar la transducción con el virus AAV-WASP3456-wt. Una vez que las células crecieron lo suficiente, el screening se realizó utilizando los primers WASP S1.1 S y WASP S1 AS.

\subsubsection{Obtención del lentivirus LV-OCT4.}

En frascos de cultivo de $75 \mathrm{~cm}^{2}$, se cultivaron células 293-FT en medio DMEM completo suplementado con $1 \%$ de NEAA y $500 \mu \mathrm{g} / \mathrm{mL}$ de geneticina, a $37^{\circ} \mathrm{C}$ y $5 \%$ de $\mathrm{CO}_{2}$, hasta que las células alcanzaron una confluencia de, aproximadamente, el $80 \%$.

Media hora antes de realizar la transfección, el medio de cultivo se cambió por $12 \mathrm{~mL}$ de DMEM suplementado, libre de antibióticos, y se dejó incubando en las condiciones mencionadas anteriormente.

La transfección se realizó empleando el método de los liposomas catiónicos, de la siguiente manera: en un tubo estéril se mezclaron $10 \mu \mathrm{g}$ del pSin-EF2-Oct4-Pur, 7,5 $\mu \mathrm{g}$ del psPAX2 y $5 \mu \mathrm{g}$ del pMD2.G, en $500 \mu \mathrm{L}$ de Opti-MEM. En otro tubo se 
mezclaron $45 \mu \mathrm{L}$ de Lipofectamina 2000 con $500 \mu \mathrm{L}$ de OptiMEM. Esto se dejó durante 5 minutos a temperatura ambiente, tras lo cual se añadió la solución con los plásmidos, gota a gota, sobre la solución con Lipofectamina. Esta nueva mezcla se incubó durante 20 minutos a temperatura ambiente. Pasado este tiempo, la solución se añadió al cultivo de células 293FT, agitando lentamente para permitir que los complejos se distribuyan uniformemente. Las células transfectadas se incubaron en una atmósfera de $5 \%$ de $\mathrm{CO} 2$ a $37^{\circ} \mathrm{C}$.

Al día siguiente, el medio se reemplazó con $12 \mathrm{~mL}$ de DMEM completo y se continuó con la incubación en las mismas condiciones descritas 24 horas más, tras lo cual se recogió el medio y se añadieron otros $12 \mathrm{~mL}$ de DMEM suplementado a las células. El medio recogido, se centrifugó a 1500 rpm durante 5 minutos y se almacenó el sobrenadante $\mathrm{a}-80^{\circ} \mathrm{C}$. Veinticuatro horas después se recogió nuevamente el medio y se descartaron las células. El medio fue centrifugado en iguales condiciones que el día previo.

Ambos sobrenadantes se juntaron y se filtraron con filtro de 0,45 $\mu \mathrm{m}$. Posteriormente, la muestra filtrada se centrifugó en la centrífuga Beckman Avanti J25, con rotor JA25.50 a $22.000 \mathrm{rpm}$ y $13^{\circ} \mathrm{C}$, durante 2 horas. Finalizado este tiempo, se descartó el sobrenadante y se dejó el tubo boca abajo sobre papel, para que pudiese escurrir cualquier resto líquido, durante 1 hora. Finalmente se añadieron $500 \mu \mathrm{L}$ de HSA $1 \%$ al pellet, y así se dejó durante 24 horas a $4^{\circ} \mathrm{C}$, tras lo cual se resuspendió y se alicuotó el virus para almacenarlo a $-80^{\circ} \mathrm{C}$.

\subsubsection{Cuantificación del título lentiviral.}

Para cuantificar el título del LV-Oct4 se tomó una alícuota de $50 \mu \mathrm{L}$ la cual se mezcló con $150 \mu \mathrm{L}$ de PBS. Esto se purificó mediante columnas, utilizando el kit PureLink Viral RNA/DNA Mini kit (Invitrogen) según protocolo. Al finalizar el proceso, el RNA purificado se cuantificó mediante NanoDrop.

Posteriormente se procedió a la síntesis del cDNA, la cual se realizó utilizando 0,5 $\mu \mathrm{g}$ de RNA, 5X de mix de reacción (5X reverse-transcription reaction mix. iScript cDNA Synthesis Kit), todo en un volumen final de $20 \mu \mathrm{L}$. Las condiciones utilizadas para la reacción, fueron las siguientes: 5 minutos a $25^{\circ} \mathrm{C}, 30$ minutos a $42^{\circ} \mathrm{C}$, y 5 minutos a $85^{\circ} \mathrm{C}$. Una vez finalizada la reacción, la muestra se diluye 10 veces en $\mathrm{H}_{2} \mathrm{O}$. 
Los volúmenes de reacción utilizados para realizar la RT-qPCR en LightCycler® 480 (Roche), fueron: $12.5 \mu \mathrm{L}$ de SYBR Green I Master $+1.5 \mu \mathrm{L}$ primer ITR S $(10 \mu \mathrm{M})+1.5$ $\mu \mathrm{L}$ primer ITR AS $(10 \mu \mathrm{M})+5 \mu \mathrm{L}$ de cDNA (1:10), en un volumen total de $25 \mu \mathrm{L}$. Los primers utilizados para realizar la titulación, el LV-OCT4 S y el LV-OCT4 AS (Sastry et al., 2002). Las condiciones utilizadas para la llevar a cabo la RT-qPCR, son las siguientes: desnaturalización, 1 ciclo de 10 minutos a $95^{\circ} \mathrm{C}$; PCR: 40 ciclos de $[15$ segundos a $95^{\circ} \mathrm{C}, 30$ segundos a $60^{\circ} \mathrm{C}, 40$ segundos a $72^{\circ} \mathrm{C}$; curva de melting 1 ciclo de $\left[1\right.$ minuto a $65^{\circ} \mathrm{C}, 1$ minuto a $35^{\circ} \mathrm{C}, 1$ segundo a $65^{\circ} \mathrm{C}$ y $95^{\circ} \mathrm{C}$ continuo], y por último, enfriamiento, 1 ciclo de 30 segundos a $40^{\circ} \mathrm{C}$.

En paralelo a la cuantificación del LV se ha realizado un curva patrón. Conociendo el tamaño y la concentración del plásmido pSin-EF2-Oct4-Pur, hemos calculado el número de copias de cada una de las diluciones de la curva patrón. Las diluciones van desde $10^{4}$ copias $/ \mu \mathrm{L}$ a $10^{8}$ copias $/ \mu \mathrm{L}$. Todas las muestras utilizadas para la realización de RT-qPCR se han puesto por triplicado.

Una vez finalizada la reacción, realizamos los análisis correspondientes con el software de análisis del LightCycler® 480 (Roche) para obtener una recta patrón a partir de los valores estándar así como los valores de título viral. El análisis de las curvas de disociación nos permitió comprobar la especificidad de las reacciones de amplificación.

\subsubsection{Transdiferenciación de fibroblastos corregidos a células hematopoyéticas.}

Para realizar la conversión de fibroblastos a células $C D 45^{+}$se siguió el protocolo establecido por Szabo et al., 2010, donde se utilizará el medio de conversión de fibroblastos (FCM), compuesto por: DMEM/F12 / 10\% KO serum replacement / 1\% NEAA / 1\% GlutaMAX I / 0,1 mM $\beta$-mercaptoetanol / 16 ng/mL bFGF / 30 ng/mL IGFII.

Para comenzar este experimento, lo primero que se hizo fue diluir 125 veces (método de capa fina, del inglés, thin layer method) la matriz Geltrex (que se mantuvo todo el tiempo en hielo). Esta dilución se realizó en medio completo de fibroblastos, frío. Se añadieron $300 \mu \mathrm{L}$ por pocillo en placa de 12 , y se incubó durante 1 hora a $37^{\circ} \mathrm{C}$. Una vez transcurrido este tiempo, el medio se quitó por completo y en el pocillo, se sembraron 10.000 fibroblastos humanos corregidos, en medio completo de fibroblastos. 
A las 24 horas, se retiró el medio y se añadió un medio conformado por $50 \%$ de DMEM completo de fibroblastos y $50 \%$ de FCM con $20 \%$ de KO serum replacement. Este medio contenía, además, $8 \mathrm{~g} / \mathrm{mL}$ de polybrene, y sobre todo esto se añadió el LV-OCT4 a una MOI de $10^{2}$.

Transcurridas 24 horas de la transducción viral, se retiró el medio y se añadieron 300 $\mu \mathrm{L}$ de FCM suplementado con $300 \mathrm{ng} / \mathrm{mL}$ de SCF y $300 \mathrm{ng} / \mathrm{mL}$ de IIt3L. Este medio, así suplementado, se utilizó durante todo experimento, cambiando cada 2 días el medio a las células, hasta el día 37 .

El día 37, contando como día 1 aquel en que se realizó la transducción, las células fueron levantas utilizando Colagenasa IV $(4 \mathrm{mg} / \mathrm{mL})$ durante 5 minutos a $37^{\circ} \mathrm{C}$. Luego, las células fueron centrifugadas durante 5 minutos a $1.000 \mathrm{rpm}$, y posteriormente lavadas con PBS.

Las células fueron divididas en 4 alícuotas.

1. La primera se utilizó como control negativo, sin ningún anticuerpo, por lo que fue resuspendida en $500 \mu \mathrm{L}$ de tampón para FACS ( $1 \mathrm{~g} / \mathrm{L} \mathrm{NaN} \mathrm{Na}_{3} / 5 \% \mathrm{FBS} / \mathrm{PBS}$ ).

2. La siguiente muestra fue utilizada para teñir con un anticuerpo $\alpha$-CD45-PE-Cy7. Para ello se añadieron $3 \mu \mathrm{L}$ del anticuerpo a las células resuspendidas en $10 \mu \mathrm{L}$ de tampón para FACS, y se incubó durante 30 minutos en hielo. Transcurrido este tiempo, las células fueron lavadas dos veces con el mismo tampón a lo cual le siguieron dos centrifugaciones de 5 minutos a $300 \mathrm{xg}$. Finalmente, las células fueron resuspendidas en $500 \mu \mathrm{L}$ de tampón para FACS.

3. La siguiente muestra, fue sometida a una tinción intracelular con un anticuerpo $\alpha$ WASP-APC. Para ello, se resuspendieron las células en $10 \mu \mathrm{L}$ de tampón para FACS, y luego se añadieron $100 \mu \mathrm{L}$ de solución de fijación durante 15 minutos. Transcurrido este tiempo, las células se lavaron dos veces con tampón para FACS, centrifugando entre medio. Se resuspendieron, nuevamente, las células en $10 \mu \mathrm{L}$ de tampón para FACS y sobre ello, se añadieron $100 \mu \mathrm{L}$ de solución de fijación junto con $1 \mu \mathrm{L}$ del anticuerpo ya marcado. Tras 30 minutos, las células se lavaron y centrifugaron 2 veces, y finalmente, se resuspendieron en $500 \mu \mathrm{L}$ de tampón para FACS.

4. La última alícuota se utilizó para hacer un doble marcaje. En primer lugar, se realizó el marcaje con el anticuerpo $\alpha$-CD45-PE-Cy7, tal como se explicó en el punto 2. A continuación, se realizó el marcaje intracelular con el $\alpha$-WASP-APC, tal 
como se explicó en el punto 3. Finalmente, las células se resuspendieron en 500 $\mu \mathrm{L}$ de tampón para FACS.

Todo lo hasta aquí realizado, fue hecho en hielo y con los reactivos a $4^{\circ} \mathrm{C}$, con excepción de las soluciones de fijación y permeabilización pertenecientes al FIX \& PERM KIT, que se encontraban a temperatura ambiente.

Las muestras se mantuvieron a $4^{\circ} \mathrm{C}$, en la oscuridad, hasta el momento de la lectura, la cual se realizó en el citómetro de flujo Gallios ${ }^{\mathrm{TM}}$ de Beckman Coulter.

Con una alícuota de estas células se realizó un western blot para comprobar la expresión de la proteína. Se utilizó un anticuerpo primario $\alpha$-WASPK374 y un secundario $\alpha-\lg G$ de conejo. 


\section{RESULTADOS.}

"El experimentador que no sabe lo que está buscando, no comprenderá lo que encuentra"

Claude Bernard (1813 - 1878) 


\section{Generación de una línea celular reportera.}

Nos propusimos generar una línea celular reportera que nos permitiera evaluar cambios en la frecuencia de recombinación homóloga en distintas condiciones experimentales.

Para ello, primero se construyó un vector de homología que permitiera la introducción de un cDNA truncado de EGFP en el sitio AAVS1 del cromosoma 19, el vector MCS$\Delta 3-E G F P t r u n c-v e c t o r$. La construcción de este vector se llevó a cabo mediante la amplificación por PCR de 3 fragmentos génicos, para lo cual se utilizó una polimerasa de alta fidelidad.

1. El primero de los fragmentos, de $1.9 \mathrm{~kb}$, fue amplificado a partir del plásmido comercial pAAV-CAGGS-EGFP, y contiene una secuencia homóloga al sitio de inserción de los AAVs, el sitio AAVS1 y, a continuación, el casete de resistencia a puromicina, precedido por la secuencia SA-2A-Puro-PolyA, según se explicó en el apartado 2.3.1 de materiales y métodos.

2. El segundo fragmento, de $1.3 \mathrm{~kb}$ se obtuvo mediante $\mathrm{PCR}$ a partir del plásmido comercial pEGFP-C1 y permitió la amplificación de EGFP, con una deleción de los últimos 73 bp (extremo 3') lo que hace que la proteína resultante no sea funcional, es decir, no emite fluorescencia verde.

3. Finalmente, el último inserto se obtuvo a partir de DNA genómico de células HCT116, amplificándose un fragmento de $1.3 \mathrm{~kb}$ cuya secuencia es homóloga a al sitio AAVS1 en el cromosoma 19, localizado en el intrón 1.

Los tres fragmentos se purificaron a partir de una electroforesis en gel de agarosa, y fueron digeridos con Notl/Sall, Sall/EcoRI y EcoRI/Notl, sitios que fueron introducidos en los primers utilizados para las diferentes PCRs. Finalmente, estos fragmentos fueron nuevamente purificados a partir de un gel de agarosa, y con ellos se realizó, luego, la ligación en el vector pAAV-MCS previamente digerido con Notl. Para analizar las colonias que incorporaron los tres insertos correctamente se procedió al análisis por enzimas de restricción mediante el uso combinado de Notl/Sall, Sall/EcoRI y EcoRI/Notl. Al analizar el patrón de restricción obtenido, se pudo observar la presencia de colonias bacterianas que incorporaron los tres insertos ligados correctamente. Según las enzimas utilizadas (Figura 14.A), los pesos esperados fueron los siguientes:

1. EcoRI/Notl: 1.300 bp, 2.900 bp y 3.200 bp.

2. Sall/EcoRI: 1.300 bp, 1.900 bp y 4200 bp.

3. Notl/Sall: $1.900 \mathrm{bp}, 2.600 \mathrm{bp}$ y $2.900 \mathrm{bp}$. 


\section{A}

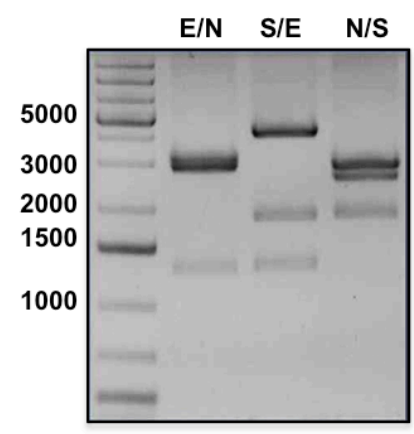

\section{B}

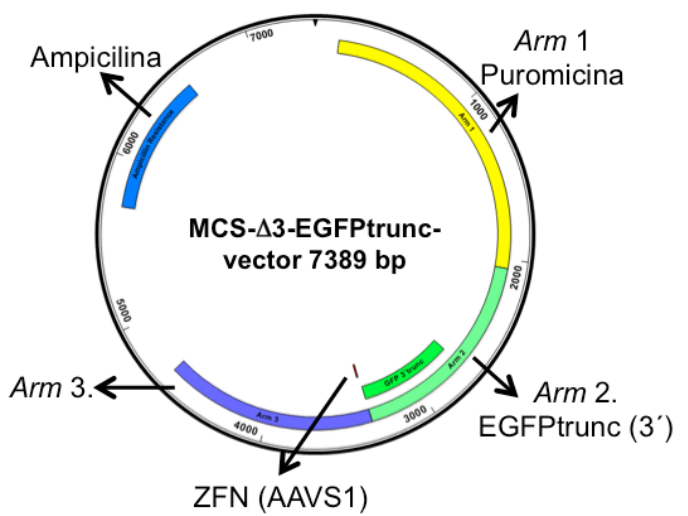

Figura 14. MCS- $\triangle$ 3-EGFPtrunc-vector. A. Se observan las digestiones de comprobación del plásmido, realizadas con EcoRI/Notl, Sall/EcoRI y Notl/Sall, donde se obtienen los pesos esperados. B. Se observa el mapa del plásmido construido.

Una de las colonias positivas obtenidas en el punto anterior, se utilizó para la extracción del DNA plasmídico mediante midiprep. Se comprobó su pureza y se confirmó nuevamente con las enzimas utilizadas previamente, que el patrón de restricción era correcto. Este plásmido fue luego nucleofectado en células HCT-116 junto con dos mRNAs que codifican para una pareja de ZFNs (de muy alta eficiencia para producir un corte en el DNA endógeno y permitir la incorporación del DNA exógeno en el sitio del corte). Las células se mantuvieron en placas de 6 pocillos durante 48 horas, tras lo cual, las células fueron sembradas en pocillos de placas de 96, hasta que se obtuvieron clonas lo suficientemente grandes para ser analizadas. Tras extraers el DNA, se realizaron las PCRs de comprobación con el fin de verificar la correcta inserción de los extremos 5' (figura 15.B) y 3' (figura 15.C).

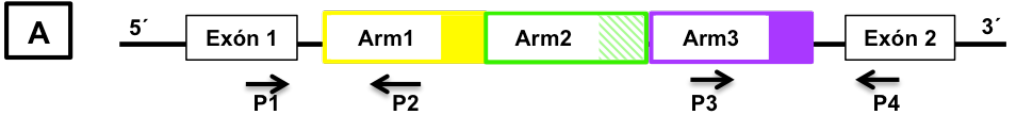

B

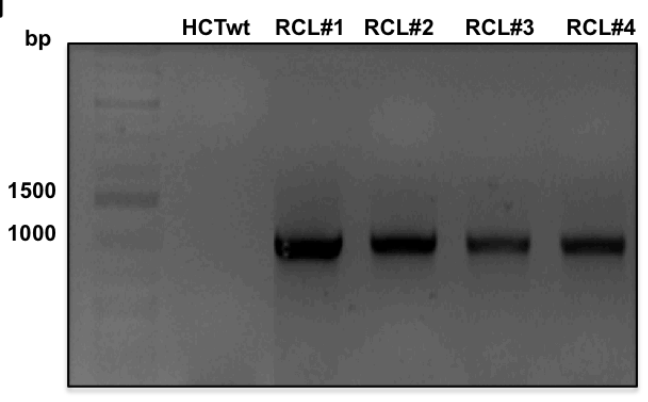

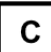

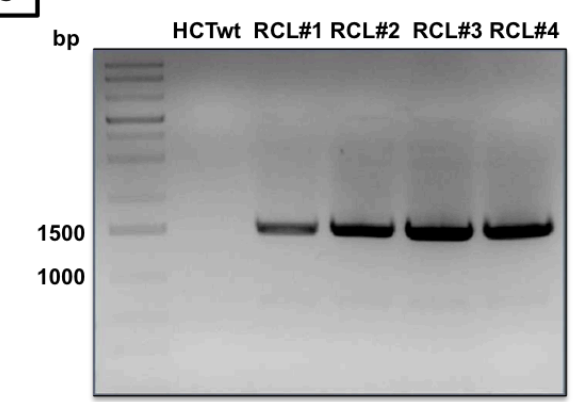

Figura 15. Línea celular reportera. A. Esquema de la inserción del plásmido MCS- $\Delta 3$-EGFPtrunc-vector en el genoma de las células HCT116. Las flechas indican los primers utilizados para comprobar dicha inserción. P1 (RCLS1 S), P2 (RCLS1 AS), P3 (RCLS2 S) y P4 (RCLS2 AS). B. PCR realizada para comprobar la inserción en el extremo $5^{\prime}$, para la cual se utilizaron los primers P1 y P2. En el primer carril no se ve amplificado, ya que corresponde a la célula wt, mientras que en las 4 clonas se ve un amplificado de 1.000 bp que corresponde a la banda esperada para una correcta inserción. C. PCR realizada para comprobar la inserción en el extremo $3^{\prime}$, para la cuales se utilizaron los primers P3 y P4. Ocurre lo mismo que en la figura anterior, solo que esta vez la banda esperada para una inserción correcta es de $1.500 \mathrm{bp}$. 
Los resultados observados en un gel de agarosa fueron: bandas de 1.000 bp corresponden a una correcta inserción para el extremo 5', mientras que bandas de $1.500 \mathrm{bp}$, lo indican para el extremo $3^{\prime}$.

\section{Obtención y cuantificación del rAAV donante: AAV- $\triangle 5-E G F P$ - donor.}

Una vez que generamos la línea celular reportera, necesitamos poner a punto los ensayos de $\mathrm{RH}$, para lo cual decidimos utilizar un virus adenoasociado (AAV- $\triangle 5$ EGFP-donor) que contiene la secuencia necesaria para corregir la función de la EGFP endógena, cuando ocurre $\mathrm{RH}$ entre el genoma de la línea reportera y el genoma del rAAV.

La razón de elegir un virus de este tipo como "agente corrector" se debe a las descripciones previas encontradas en la bibliografía que demuestran un incremento en varios órdenes de magnitud en la frecuencia de $\mathrm{RH}$ inducida por este tipo de vectores comparado con vectores plasmídicos estándar.

Este vector se construyó, también, con tres brazos diferentes.

1. El brazo 1, que contiene un fragmento de EGFP que carece de los $38 \mathrm{bp}$ del extremo 5', se obtuvo mediante amplificación por PCR del plásmido comercial pEGFPN1, purificándose a partir de una electroforesis en gel de agarosa una banda de $1 \mathrm{~kb}$. Dentro de las $38 \mathrm{bp}$ que no se incluyen, se encuentra la ATG y, por tanto, la proteína resultante no se produce y no hay, en consecuencia, emisión de fluorescencia verde. La banda purificada a partir de una electroforesis en gel de agarosa, se digirió con las enzimas Notl/Sal, cuyos sitios fueron introducidos con los primers utilizados durante la PCR.

2. El brazo 2, de $1.6 \mathrm{~kb}$, se obtuvo directamente mediante digestión con las enzimas Sall/EcoRI del plásmido pBS-Blasticidin, construido en el laboratorio, el cual contiene el casete de resistencia blasticidina, que será el antibiótico de selección que nos permitirá seleccionar las células verdes recombinantes.

3. El brazo 3 necesario para este vector, es común al utilizado descrito anteriormente en la generación del MCS- $\Delta 3$-EGFPtrunc-vector.

Una vez obtenidos los tres fragmentos, estos se ligaron al vector pAAV-MCS ya digerido con Notl. Las colonias bacterianas obtenidas, se analizaron mediante diversas digestiones enzimáticas (figura 16), con el fin de asegurarnos la incorporación correcta de los insertos. Según las enzimas utilizadas, los pesos esperados fueron: 
1. Notl/Sall: 300 bp, 2.900 bp y 3.500 bp.

2. Sall/EcoRI: 1.600 bp y $5.100 \mathrm{bp}$.

3. EcoRI/Notl: $1.300 \mathrm{bp}, 1.900 \mathrm{bp}$ y $3.500 \mathrm{bp}$.

\section{A}

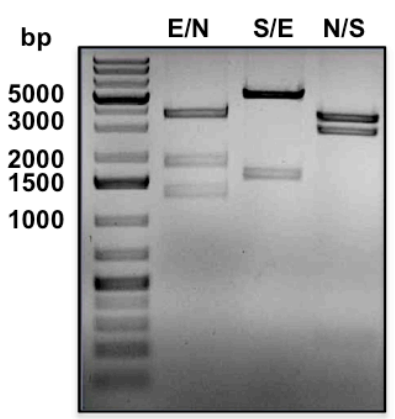

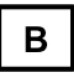

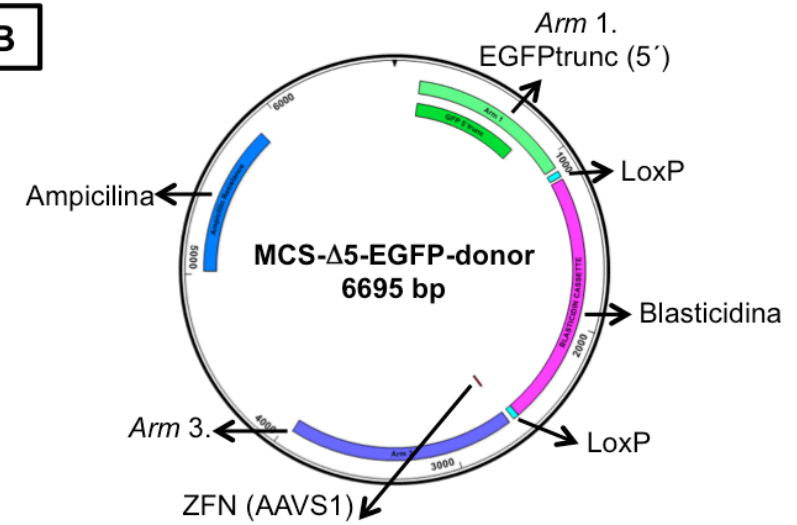

Figura 16. MCS- $\triangle 5$-EGFP-donor. A. Se observan las digestiones de comprobación del plásmido, realizadas con EcoRI/Notl, Sall/EcoRI y Notl/Sall, donde se obtienen los pesos esperados. B. Se observa el mapa del plásmido construido,

Este plásmido se usó junto con el pAAV-RC y el pHelper para la producción del virus recombinante correspondiente, en las células empaquetadoras (AAV293). Antes de realizar la transfección de los tres plásmidos mencionados anteriormente, fue imprescindible que dichas células se encontraran a una confluencia de $80-90 \%$. Desde el momento en que se realizó la transfección, y luego de unas horas, se pudo observar cómo estas células fueron cambiando su morfología, se fueron redondeando, y muchas de ellas comenzaron a despegarse de la superficie plástica en la que se encontraban (figura 17). Todos estos cambios, que se fueron acentuando con el paso del tiempo, son debidos al efecto citopático que causa el virus al replicarse dentro de las células. Después de 72 horas de haber realizado la transfección, las células fueron levantadas mediante raspado del soporte y, posteriormente, lisadas en 4 ciclos de congelación-descongelación, tras lo cual se obtuvieron, finalmente, las partículas virales en suspensión. 


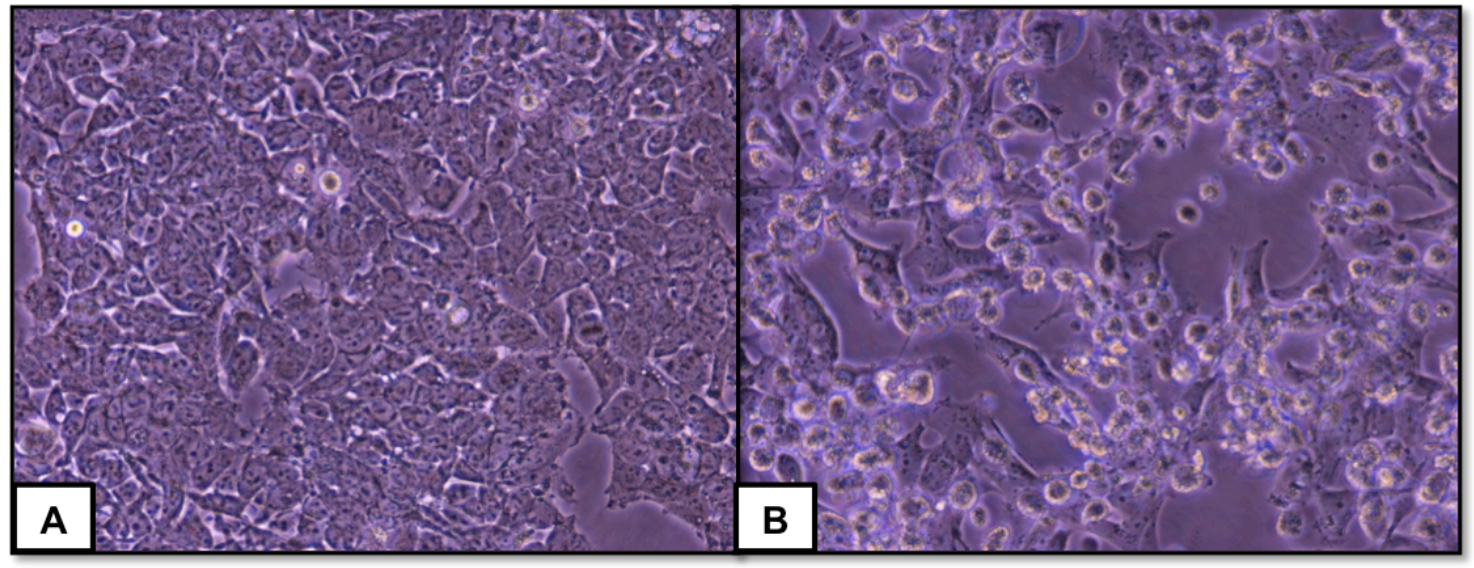

Figura 17. Células AAV293. A. Células antes de realizar la co-transfección de los plásmidos. Estas se encuentran adheridas al soporte, con una confluencia de $90 \%$, aproximadamente y en buen estado. B. 72 horas después de haberse realizado la co-transfección, las células demuestran el efecto citopático ejercido por el AAV en producción.

La cuantificación del título viral es un paso muy importante, para poder conocer cual es la dosis viral óptima a usar en los diferentes experimentos. Es por ello que se tituló el lisado celular obtenido previamente, mediante PCR cuantitativa. La curva de calibración se generó usando el plásmido pAAV-MCS, que contiene las secuencias ITRs. Hay que tener en cuenta que el plásmido contiene 4 ITRs, mientras que el AAV sólo contiene 2, debido a que el plásmido está formado por un dsDNA y el AAV por un ssDNA, por lo que se debe hacer la corrección correspondiente en el cálculo final. De este modo, por comparación entre la curva patrón, de concentraciones conocidas, y las diferentes diluciones del lisado viral, se obtuvo el título de cada una de las muestras. Los títulos de los virus fueron de $10^{9}-10^{10}$ partículas virales $/ \mathrm{mL}$, el cual se considera dentro del rango óptimo (Büning et al., 2003).

Antes de continuar con los diferentes experimentos utilizando el rAAV2 se llevó a cabo un ensayo para evaluar la eficiencia de transducción del mismo. Para ellos hemos utilizado un rAAV que contiene un casete de EGFP dirigido por un promotor CMV. El virus fue posteriormente transducido en células HCT116, que son las que se utilizaron para los diferentes experimentos posteriores. La transducción del rAAV se realizó a MOls que van desde los 10 a los $10^{4}$. Después de 72 horas de realizada la transducción se evaluaron, mediante microscopia de fluorescencia, el número de células verdes obtenidas, y también la mortalidad mediante utilización del colorante azul de tripán, con lo cual se obtuvo una eficiencia de transducción de un $10 \%$ de las células a una $\mathrm{MOI}$ de $10^{3}$, lo cual concuerda con datos obtenidos por otros laboratorios (Teschendorf et al., 2006), y se considera suficiente para optimizar el gasto de concentrado viral. Estos resultados se confirmaron en repetidas ocasiones, obteniéndose en todas una media del $10 \% \pm 1,5 \%$ en la eficiencia de transducción. 
Esta eficiencia de transducción se ha utilizado para el cálculo de la frecuencia de RH en los experimentos posteriores. Entonces, teniendo en cuenta tanto el número total de células con que se inició el experimento y la mortalidad debida al mismo (calculada mediante tinción con azul de tripán), y teniendo en cuenta la eficiencia de transducción del $10 \%$ se pudo calcular la frecuencia real de eventos recombinatorios (células verdes) obtenidos en cada condición:

$\left(\mathrm{N}^{\circ}\right.$ inicial de células $-\mathrm{N}^{\circ}$ de células muertas $) \times 10 \%=\mathrm{N}^{\circ}$ de células transducidas

( $\mathrm{N}^{\circ}$ eventos recombinantes $/ \mathrm{N}^{\circ}$ de células transducidas $) \times 100=$ Frecuencia de $\mathrm{RH}$.

\section{Transducción de la línea celular reportera con el virus donante AAV- $\triangle$ 5-EGFP-donor.}

Una vez que obtuvimos la línea reportera y el virus donante AAV- $\Delta 5$-EGFP-donor nos propusimos comprobar si nuestro sistema funcionaba adecuadamente, para lo cual diseñamos un ensayo de recombinación utilizando las células HCT116-RCL en cultivo. Estas se cultivaron en placas de 96 pocillos, realizándose cada experimento por triplicado, utilizando en primera instancia diferentes cantidades de rAAV a transducir $\left(10,10^{2}, 10^{3}\right.$, y $\left.10^{4} \mathrm{MOI}\right)$, tras lo cual se decidió continuar los experimentos utilizando una $\mathrm{MOI}$ de $10^{3}$ que fue la que nos resultó más efectiva en los experimentos preliminares.

A la hora de realizar cada experimento, se sembraron las células en placas de 96 pocillos con medio completo, 48 horas antes de realizar la transducción de las células HCT116-RCL con el AAV- $\triangle 5$-EGFP-donor. Transcurridos esos dos días, se realizó la transducción con el AAV a una $\mathrm{MOI}$ de $10^{3}$ partìculas virales/célula. Tres días después de realizar la transducción, se pudieron observar las células verdes (figura 18). Este resultado, nos permite asegurar que la línea celular reportera que hemos construido funciona de manera correcta, como así también el virus recombinante, ya que de otra manera no hubiéramos sido capaces de obtener células verdes recombinantes. 


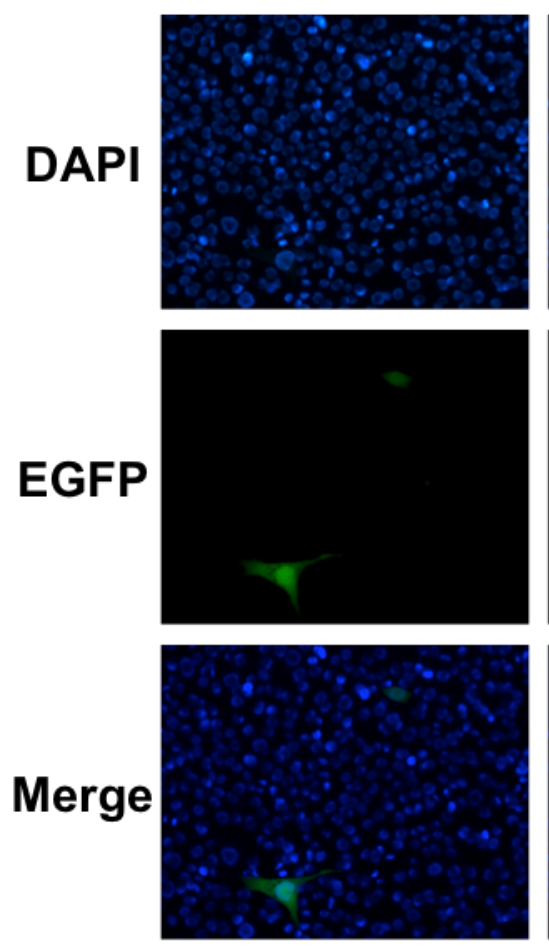

A
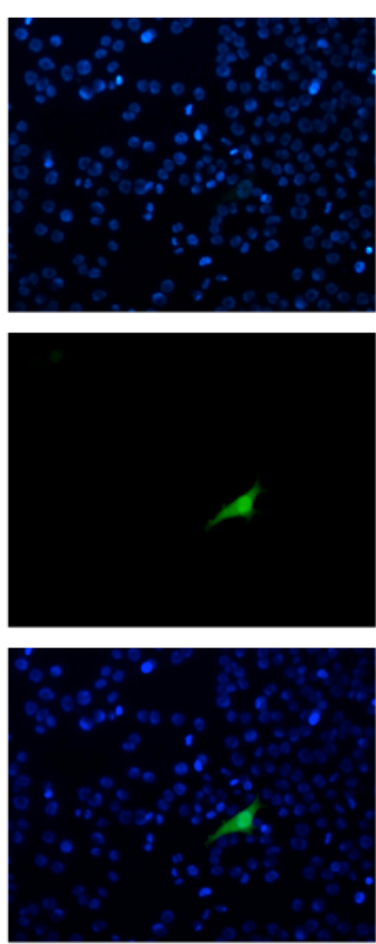

B
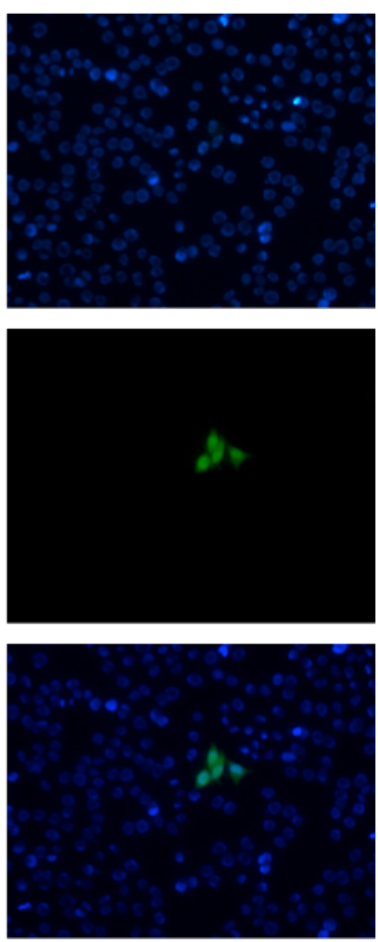

C

Figura 18. Microscopía de células HCT116-RCL transducidas con AAV- 5 -EGFP-donor. Aumento utilizado: 20X. En la parte superior de la figura se observan los núcleos de las células teñidos con DAPI. En la parte media, la expresión de EGFP en las mismas células. Y en la parte inferior se observa la superposición de las imágenes anteriores. A. Se observan dos células verdes de un total de 5 células verdes por pocillo. B. La imagen muestra una sola célula verde, de un total de 5 células verdes por pocillo. C. Clona formada 2 días después de observarse células individuales.

Las células verdes fueron aisladas por dilución límite, y una vez que se obtuvo una clona recombinante (verde) única, extrajimos el DNA para poder comprobar la correcta formación del casete de EGFP (figura 19.B), lo cual se realizó amplificando por PCR utilizando los primers RCLS3 S y RCLS3 AS y, como control, el plásmido pEGFP-N1.

A
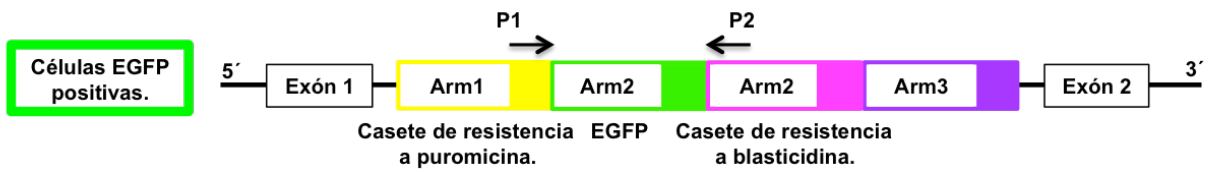
de EGFP. a puromicina.

a blasticidina.

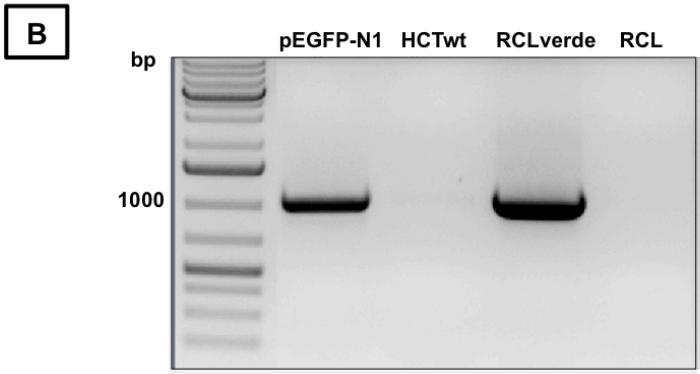

Figura 19. Célula verde HCT116-RCL. A. Esquema del DNA de la célula HCT116-RCL verde, es decir, una vez nucleofectada con el plásmido MCS- $\Delta 3$-EGFPtrunc-vector y, posteriormente, transducida con el AAV- $\triangle 5$-EGFP-donor. B. Amplificación por PCR del plásmido pEGFP-N1, de la célula HCT116wt, de la célula HCT116-RCL verde y de la célula HCT116-RCL sin transducir. La amplificación con los primers P1 (RCSL3 S) y P2 (RCLS3 AS), da una banda de $1100 \mathrm{bp}$, correspondiente al casete EGFP. 
Habiendo iniciado el experimento con 15.000 células y ajustando la mortalidad celular mediante contaje con azul de tripán y la eficiencia de transducción del virus del $10 \%$, hemos obtenido un promedio de 5 células recombinantes, por lo que la frecuencia de $\mathrm{RH}$ es de un $0,5 \% \pm 0,15 \%$, aproximadamente. Este número, si bien es un número bajo de células verdes para permitirnos hacer comparaciones entre los diferentes experimentos demuestra, en cambio, un gran aumento de la $\mathrm{RH}$ debido a la utilización del rAAV con respecto a la frecuencia de $\mathrm{RH}$ obtenida mediante la utilización de vectores plasmídicos. Por ello, y para poder elevar aún más el número de células recombinantes, y por lo tanto, la frecuencia de $\mathrm{RH}$ es por lo que decidimos utilizar las nucleasas TALEs, las cuales generan roturas dobles en la cadena de DNA, lo cual se sabe que incrementa, de manera drástica, la frecuencia de $\mathrm{RH}$. Hay que tener en cuenta que para que esto ocurra, la lesión del DNA debe localizarse en el locus que se quiere modificar. Para ello, se necesita un sistema de generación de DSBs que combine la capacidad endonucleasa (dominio de corte inespecífico por parte de la Fokl en las TALENs) con la especificidad de secuencia (dominio de reconocimiento de las TALENs).

\section{Diseño y construcción de TALENs.}

Cómo se ha mencionado anteriormente, para incrementar el número en los eventos de recombinación, decidimos construir una pareja de nucleasas TALEs específicas de locus que nos permitiera obtener un número mayor de células verdes recombinantes mediante la generación de DSBs (figura 20).

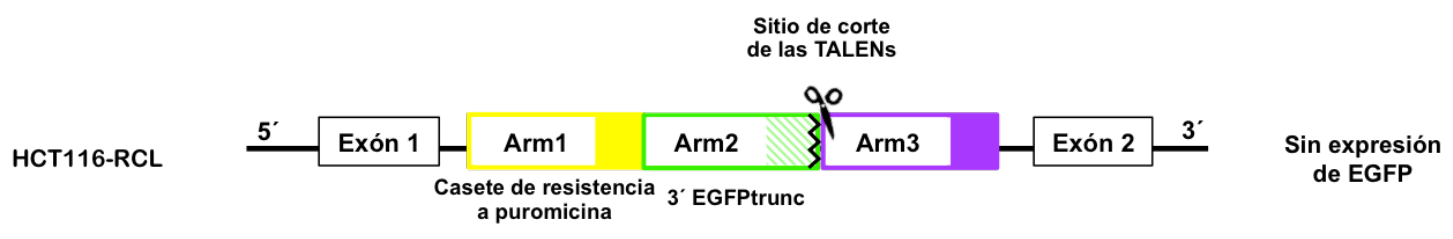

Figura 20. Célula HCT116-RCL. Esquema del DNA de la célula HCT116-RCL, con el sitio de corte para las TALENs incluido en el.

Según los softwares informáticos de predicción mencionados anteriormente en la sección de materiales y métodos, apartado 2.3.6, se han elegido las secuencias para la construcción de la pareja de TALENs adecuadas (figura 21), según el DNA molde utilizado, y junto con esto, los diferentes 2-mer y los plásmidos necesarios para construir la pareja de TALENs. 


\section{the hornung laboratory TALEN RESOURCES}

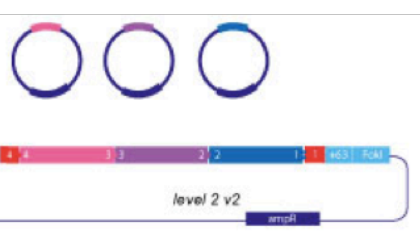

\begin{tabular}{|c|c|c|c|c|c|}
\hline \multirow{3}{*}{$\begin{array}{r}\text { home } \\
\text { people } \\
\text { research }\end{array}$} & \multicolumn{5}{|c|}{ Pipetting directions using the dimer plate available from Addgene.org: } \\
\hline & 2-mer / BB & \multirow[t]{2}{*}{ Position } & \multirow[t]{2}{*}{6 -mer } & Position & \multirow[t]{2}{*}{ volume } \\
\hline & (1) TGCCAGA & & & TALEN 1 & \\
\hline meetings & $1 \mathrm{GC} 2$ & A10 & 1GCCAGA 4 & & $2.5 \mu 1$ \\
\hline & $2 \mathrm{CA} 3$ & D5 & 1GCCAGA4 & & $2.5 \mu 1$ \\
\hline TALEN resources & $3 \mathrm{GA} 4$ & $\mathrm{C} 1$ & 1GCCAGA 4 & & $2.5 \mu 1$ \\
\hline \multirow{2}{*}{ LIC assembly of TALENs } & BB-L1-ID4 1 & G1 & 1GCCAGA4 & & $2.5 \mu 1$ \\
\hline & $4 \mathrm{AC} 1$ & E6 & 4АССТСТ 3 & & $2.5 \mu 1$ \\
\hline \multirow{4}{*}{$\begin{array}{r}\text { assembly tool } \\
15.5 \text { RVDs }\end{array}$} & $1 \mathrm{CT} 2$ & A8 & 4АССТСТ 3 & & $2.5 \mu 1$ \\
\hline & $2 \mathrm{CT} 3$ & D8 & 4АССТСТ 3 & & $2.5 \mu 1$ \\
\hline & BB-L1-ID34 & G2 & 4АССТСT3 & & $2.5 \mu 1$ \\
\hline & $3 \mathrm{AA} 4$ & B5 & 3AAGGTT2 & & $2.5 \mu 1$ \\
\hline \multirow{3}{*}{$\begin{array}{r}\text { assembly tool } \\
18.5 \text { RVDs }\end{array}$} & $4 \mathrm{GG} 1$ & F3 & 3AAGGTT2 & & $2.5 \mu 1$ \\
\hline & $1 \mathrm{TT} 2$ & B4 & 3AAGGTT2 & & $2.5 \mu 1$ \\
\hline & BB-L1-ID23 & G3 & 3AAGGTT2 & & $2.5 \mu 1$ \\
\hline FAQ & \multicolumn{3}{|c|}{ (2) TCCCTCCCAGGATCCTCTCT in BB-L2-T } & TALEN 2 & \multirow[b]{2}{*}{$2.5 \mu 1$} \\
\hline MTA & $1 \mathrm{cc} 2$ & A6 & $1 \mathrm{ccCTCC} 4$ & & \\
\hline \multirow[t]{2}{*}{ publications } & $2 \mathrm{CT} 3$ & D8 & $1 \mathrm{CCCTCC} 4$ & & $2.5 \mu 1$ \\
\hline & $3 \mathrm{CC} 4$ & B10 & $1 \mathrm{CCCTCC} 4$ & & $2.5 \mu 1$ \\
\hline news & BB-L1-ID4 1 & G1 & $1 \mathrm{CCCTCC} 4$ & & $2.5 \mu 1$ \\
\hline \multirow[t]{2}{*}{ funding } & $4 \mathrm{CA} 1$ & E9 & 4CAGGAT3 & & $2.5 \mu 1$ \\
\hline & $1 \mathrm{GG} 2$ & A11 & 4CAGGAT3 & & $2.5 \mu 1$ \\
\hline links & $2 \mathrm{AT} 3$ & D4 & 4CAGGAT3 & & $2.5 \mu 1$ \\
\hline \multirow{2}{*}{ location } & BB-L1-ID34 & $\mathrm{G} 2$ & 4CAGGAT3 & & $2.5 \mu 1$ \\
\hline & $3 \mathrm{CC} 4$ & B10 & зсСтCтC2 & & $2.5 \mu 1$ \\
\hline \multirow[t]{3}{*}{ imprint } & $4 \mathrm{TC} 1$ & F6 & зсстСтс2 & & $2.5 \mu 1$ \\
\hline & $1 \mathrm{TC} 2$ & B2 & зсстСтс2 & & $2.5 \mu 1$ \\
\hline & BB-L1-ID23 & $\mathrm{G} 3$ & зсСтстс2 & & $2.5 \mu 1$ \\
\hline
\end{tabular}

Figura 21. Imagen obtenida a partir de la página de internet $h t t p: / / w w w . h o r n u n g l a b . d e / T a s s e m b l y . h t m /$ mediante la cual hemos obtenido la secuencia de las TALENs a construir, como así también, los 2 mer que se utilizaron y los plásmidos correspondientes a cada ligación. En verde se señala cada una de las TALENs que conforman el par.

A partir de la placa comercial de plásmidos, y mediante un proceso de auto-ligación entre los plásmidos de nivel 1 (BBL1), linearizados por digestión enzimática con Pstl/Kpnl, y 3 fragmentos 2-mer obtenidos por digestión enzimática con Mva1269l, se generaron los plásmidos 6-mer. Estos fragmentos 6-mer fueron, posteriormente, liberados del plásmido en que estaban mediante digestión enzimática con Mva1269I, tras lo cual nuevamente por el proceso de auto-ligación, 3 de estos se ligaron en 
plásmidos de nivel 2 (BBL2) previamente digeridos con Kpnl, para obtenerse los dos plásmidos 18-mer finales.

Las ligaciones de los 2-mer con los BBL1 correspondientes, se realizaron según las indicaciones propuestas por The Hornung Laboratories (http://www.hornunglab.de/Tassembly.html). Posteriormente, las colonias obtenidas se comprobaron mediante digestión con Mva1269I, para confirmar la incorporación del inserto correcto. Aquellas bacterias que incorporaron el inserto ligado de manera correcta presentaron un patrón de bandas de 2700 bp y 700 bp (figura 22).

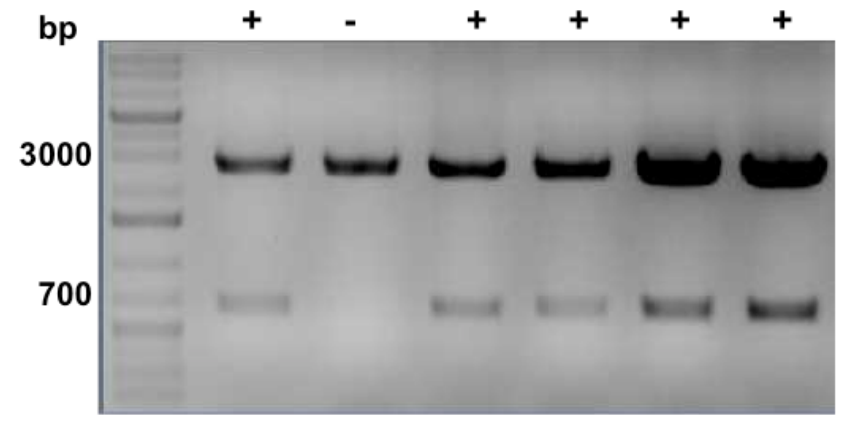

Figura 22. Imagen de las digestiones realizadas para comprobar la ligación correcta de los 6 mer. Las colonias positivas (+) son aquellas en que las se obtienen dos bandas, una de, alrededor, de $2700 \mathrm{bp}$ y otra de unos $700 \mathrm{bp}$. Cualquier otro patrón significa que la colonia es negativa (-).

Una vez que los 6-mer fueron digeridos y ligados con el BBL2-T, nuevamente se comprobaron las colonias mediante digestión enzimática, esta vez con Xbal/Xhol. Aquellas bacterias que incorporaron el inserto ligado de manera correcta, presentaron un patrón de 5500 bp y 3300 bp (figura 23).

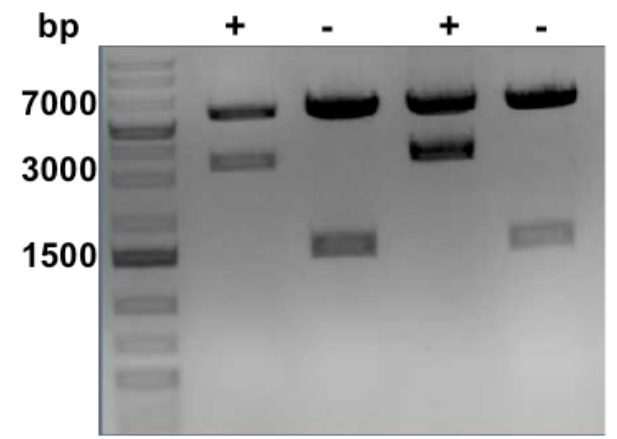

Figura 23. Imagen de las digestiones realizadas para comprobar la ligación correcta de los $18 \mathrm{mer}$. Las colonias positivas (+) son aquellas en que las se obtienen dos bandas, una de de 5500 bp y otra 3300 bp. Cualquier otro patrón significa que la colonia es negativa (-). 
A partir de estas colonias bacterianas se obtuvieron los plásmidos finales de ambas TALENs que fueron utilizados en los siguientes experimentos y que van a producir las proteínas de fusión finales (compuestas cada una por los 18 módulos tipo TALEN más la nucleasa Fokl).

\section{Funcionalidad in vitro de las TALENs en la HCT116-RCL.}

La funcionalidad de las TALENs se ha comprobado en la línea celular reportera HCT116-RCL. Para ello, el primer paso fue poner a punto las cantidades de plásmido de cada una de las TALENs necesarios en cada transfección. Después de haberse ensayado cantidades de 50 ng, 100 ng, 200 ng y 300 ng, utilizándose siempre ambos plásmidos en cantidades iguales, se llegó a la conclusión de que la cantidad óptima fue de $200 \mathrm{ng}$ de cada una de las TALENs. De esta manera, en todos los experimentos siguientes se utilizaron $200 \mathrm{ng}$ de cada uno de los plásmidos de ambas TALENs.

Para los experimentos de funcionalidad in vitro se sembraron 15.000 células en 3 pocillos de una placa de 96 pocillos. Un día después dos de los pocillos con células HCT116-RCL fueron transfectadas con los dos plásmidos que codifican para cada una de las TALENs descritas. Después de 6 horas de realizar la transfección, se cambió el medio a ambos. En el primer pocillo en que se transfectaron las células, se añadió medio completo. En el segundo pocillo en que se transfectaron las células, y en el pocillo sin tratar, se realizó la transducción con el virus AAV- -5 -EGFP-donor durante 24 horas, tras lo cual se les cambió el medio. Tres días después de la transducción, se observaron las células verdes presentes en el cultivo.

Según se puede observar en la figura 24, la transfección de ambas TALENs no da lugar a la aparición de células verdes, lo cual es debido a la ausencia del rAAV en el cultivo, es decir, a pesar de que se generan DSBs en el locus correspondiente, no hay posibilidad de $\mathrm{RH}$ en ausencia del genoma viral ya que es el que contiene la secuencia necesaria para la reconstitución de una EGFP completa funcional. Por otro lado, de igual manera que en experimentos anteriores, las células transducidas con el virus donante $\mathrm{AAV}-\triangle 5$-EGFP-donor presentan evidencia de $\mathrm{RH}$ porque aparecen células verdes. En este caso se han obtenido $0,5 \% \pm 0,15 \%$ de eventos recombinantes por pocillo. Finalmente, en las células que fueron en primera instancia transfectadas con TALENs y, posteriormente, transducidas con virus donante AAV- $\triangle 5$ EGFP-donor, también se evidencian eventos recombinantes con una frecuencia de $\mathrm{RH}$ de $3.8 \% \pm 0,7 \%$. 


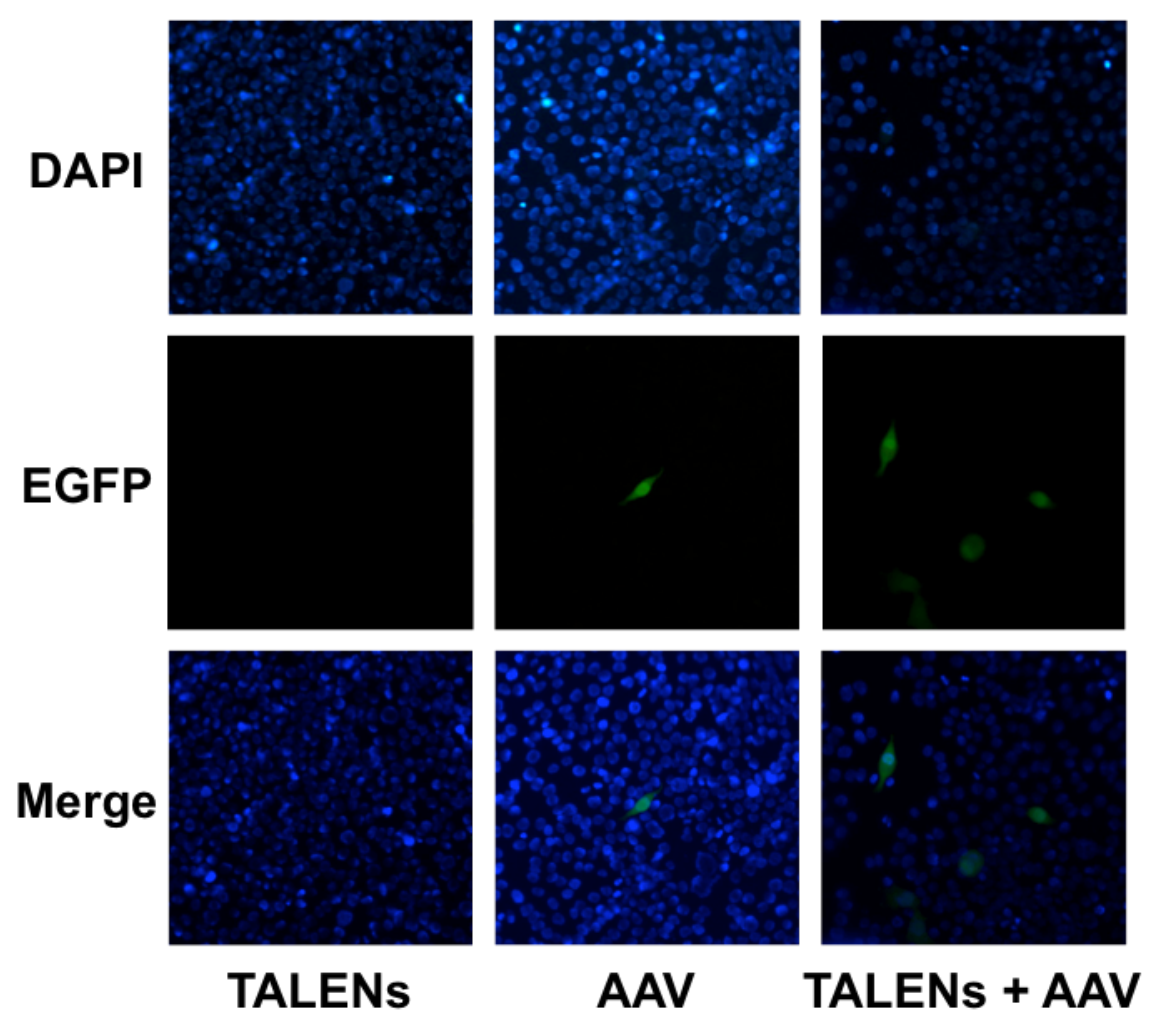

Figura 24. Microscopía de células HCT116-RCL. Aumento utilizado: 20X. En la parte superior de la figura se observan los núcleos de las células teñidos con DAPI. En la parte media, se observa la expresión de EGFP en las mismas células. En la parte inferior de la figura, se puede observar una superposición de las dos figuras previas. En la imagen del control se puede observar la ausencia de células verdes. Estas células han sido transfectadas con TALENs, pero no transducidas con AAV. En las células transducidas con AAV- 45 -EGFP-donor, se puede observar una sola célula verde, de un total de 4 células verdes. Finalmente, en las células que fueron transfectadas con TALENs y transducidas con AAV- $\triangle 5$-EGFP-donor se observan 4 células verdes, de un total de 45.

\section{Cambio en la frecuencia de recombinación homóloga: ScRad52 (Rad52 de S. cerevisiae).}

Es conocido que Rad52 es una de las proteínas que interviene en la reparación del DNA mediante $\mathrm{RH}$, y que la actividad funcional in vitro es mayor en ScRad52 que en la proteína humana. También se ha descrito por otros un aumento en la $\mathrm{RH}$ de más de 30 veces en células HeLa que sobreexpresan ScRad52, en relación a células control (Di Primio et al., 2005). Basándonos en estos antecedentes decidimos producir la proteína de fusión ScRad52 recombinante en bacterias para lo que subclonamos el gen de ScRad52, in frame con un casete aminoterminal compuesto por las regiones His-tag, Tat y NLS (sentido $5^{\prime} \rightarrow 3^{\prime}$ ). La proteína fue, posteriormente, expresada, purificada y cuantificada, y a partir de allí utilizada para realizar los experimentos de $\mathrm{RH}$.

Los experimentos realizados con la proteína de fusión ScRad52 fueron llevados a cabo por triplicado, plaqueándose 15.000 células HCT116-RCL, 24 horas antes de realizar el experimento. El día del experimento se transfectaron las TALENs, que se 
mantuvieron en cultivo por otras 6 horas, tras lo cual se sustituyó el medio de transfección por OptiMem, sobre el cual se añadieron diferentes cantidades de ScRad52. Una hora después, se realizó la transducción con el AAV- $\Delta 5$-EGFP-donor $\left(10^{3} \mathrm{MOI}\right)$, que se mantuvo durante 24 horas. Dos a tres días después de la transfección se observaron las células verdes.

En los diferentes experimentos realizados con ScRad52, hemos comprobado la actividad de la proteína en un rango entre $0.025 \mu \mathrm{g}$ y $12.5 \mu \mathrm{g}$, con lo cual podemos asegurar que la proteína de fusión que hemos producido en el laboratorio es una proteína funcional y que, además, junto con las TALENs, induce una frecuencia de RH a $4.5 \% \pm 1 \%$ (figura 25 ).

El análisis estadístico de los datos obtenidos en los estudios realizados en líneas celulares con ScRad52 se realizó en el programa informático Excel mediante el cual se calculó la desviación estándar y el test t de Student, para muestras pareadas, pues se trataba de muestras independientes procesadas en paralelo en cada uno de los triplicados. Los valores obtenidos durante el análisis estadístico pueden encontrarse en el apartado 3.1 del anexo.

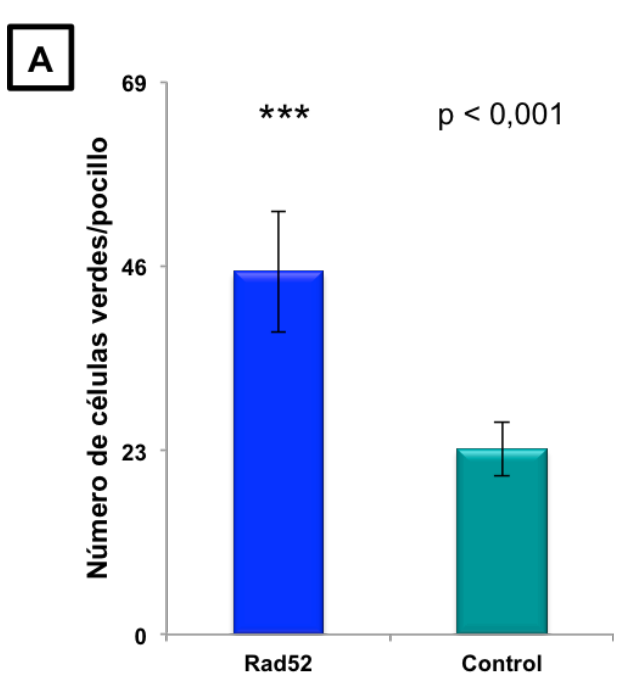

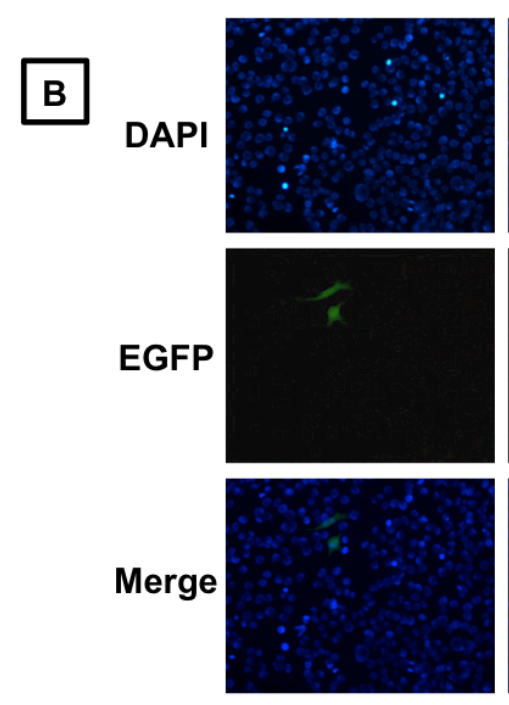

TALEN+AAV
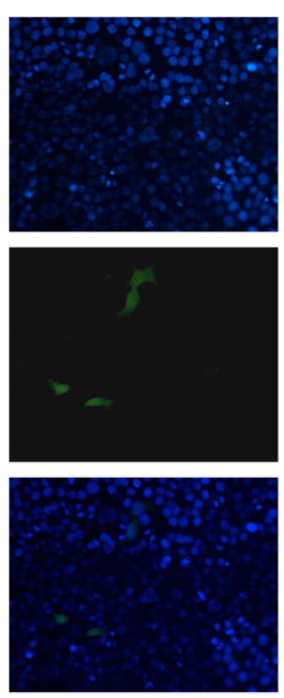

TALEN+RAD52

+AAV

Figura 25. Resultado de la utilización de ScRad52 sobre la frecuencia de RH. A. Número de células verdes obtenidas en los experimentos realizados, frente a la condición control sin ScRad52. B. Fotografías obtenidas de la HCT116-RCL sin tratar y tratada con ScRad52. Con $\left({ }^{* * *}\right)$ se indica que el resultado obtenido es estadísticamente significativos $(p<0,001)$. Con (I) se indica la desviación estándar de cada experimento. 


\section{Cambio de la frecuencia de recombinación homóloga: librería de siRNAs.}

Ya que la reparación en las roturas en el DNA pueden ocurrir por dos mecanismos principales, la $\mathrm{RH}$ y la NHEJ, y habiendo establecido que diferentes proteínas participan en una u otra vía, nos propusimos ensayar en nuestra línea celular reportera HCT116-RCL cómo afectan algunas de estas proteínas al proceso de recombinación, utilizando la técnica de silenciamiento génico por siRNAs de varias de estas proteínas. De esta manera, utilizamos siRNAs dirigidos contra proteínas que intervienen en la NHEJ con lo cual se buscó favorecer los mecanismos de RH.

Dentro de la librería contamos con siRNAs de última generación, silencer select que fueron químicamente modificados, lo que les confiere la ventaja de ser más estables y más efectivos y específicos a dosis hasta 10 veces menores con respecto a los siRNAs normales.

Antes de llevar a cabo los experimentos con la librería de siRNAs, se estableció primero el protocolo óptimo para la transfección de siRNAs, TALENs y transducción del rAAV. Así pues, se realizaron pruebas transfectando los siRNAs y a las 12, 24, 36, 48 y 60 horas se transfectaron las TALENs. A partir de los resultados obtenidos a partir de estos experimentos se concluyó que las mejores condiciones experimentales consistían en transfectar los siRNAs 24 horas antes de realizar la transfección de las TALENs, y posteriormente el rAAV (figura 26).

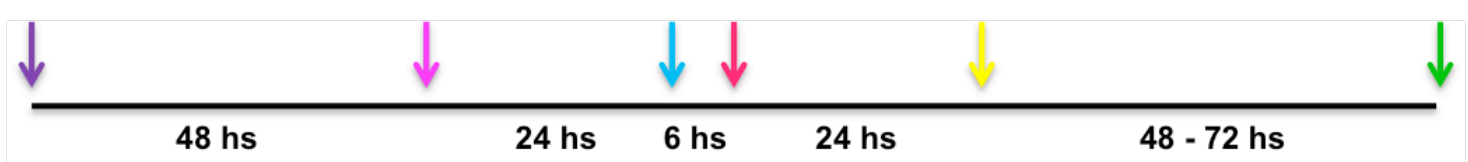

$24 \mathrm{hs}$

$24 \mathrm{hs}$

$48-72$ hs

Se siembran 10.000 células en placa de 96 pocillos.

Se transfectan los siRNAs.

Se transfectan los plásmidos correspondientes a la pareja de TALENs.

Se realiza la transducción del virus donante (AAV- $\Delta 5$-EGFP-donor).

Se retira el medio de transducción y se añade medio completo fresco.

Comienzan a observarse células recombinantes verdes.

Figura 26. Esquema de la realización del experimento con siRNAs, TALENs y rAAV. En la figura pueden observarse los tiempos utilizados en la realización de cada uno de los pasos. 
Cuarenta y ocho horas después de haber sembrado las células en pocillos de placas de 96, se transfectaron los siRNAs a las concentraciones correspondientes. A las 24 horas, se transfectaron las TALENs, y 6 horas más tarde, se retiró el medio y las células fueron transducidas con el AAV- $\Delta 5$-EGFP-donor durante otras 24 horas. Dos o tres días después de la transducción, las células verdes ya se observaban en el cultivo celular.

En cada experimento se utilizó un siRNA control negativo y los correspondientes siRNAs específicos, sin otros tratamientos. Se observó entonces, que la mortalidad celular obtenida a las 48 - 72 horas no superó en ningún caso el $5 \%$ comparado con las células sin tratar con siRNAs. Otro control ensayado consistió en comparar el efecto de tratar las células tratadas con TALENs + rAAV, con y sin el siRNA control negativo. En este caso, hemos obtenido que en las células tratadas con siRNA + TALENs + rAAV se obtenía un número de eventos recombinates menor que en el obtenido en las células con TALENs + rAAV. La diferencia entre el número de eventos recombinantes es del $5 \% \pm 1 \%$, lo cual se correlaciona con la mayor mortalidad celular encontrada en las células tratadas con siRNA + TALENs + rAAV.

Habiéndose ensayado un total de 84 siRNAs dirigidos contra genes diferentes, todos por triplicado, encontramos que los resultados obtenidos varían según la molécula utilizada, y que muchos siRNAs tienen la capacidad de aumentar la frecuencia de recombinación homóloga mientras que otros, o no producen cambios, o bien, disminuyen la frecuencia de recombinación. En la figura 27 se pueden ver los cambios producidos en la frecuencia de recombinación homóloga, causada por cada uno de los siRNAs.

El análisis estadístico de los datos obtenidos en los estudios realizados con la librería de siRNAs en líneas celulares se realizó con el programa informático Excel, mediante el cual se calculó la desviación estándar y el test $t$ de Student, para muestras pareadas, pues se trataba de muestras independientes procesadas en paralelo en cada uno de los triplicados. Los valores obtenidos durante el análisis estadístico pueden encontrarse en el apartado 3.2 del anexo. 

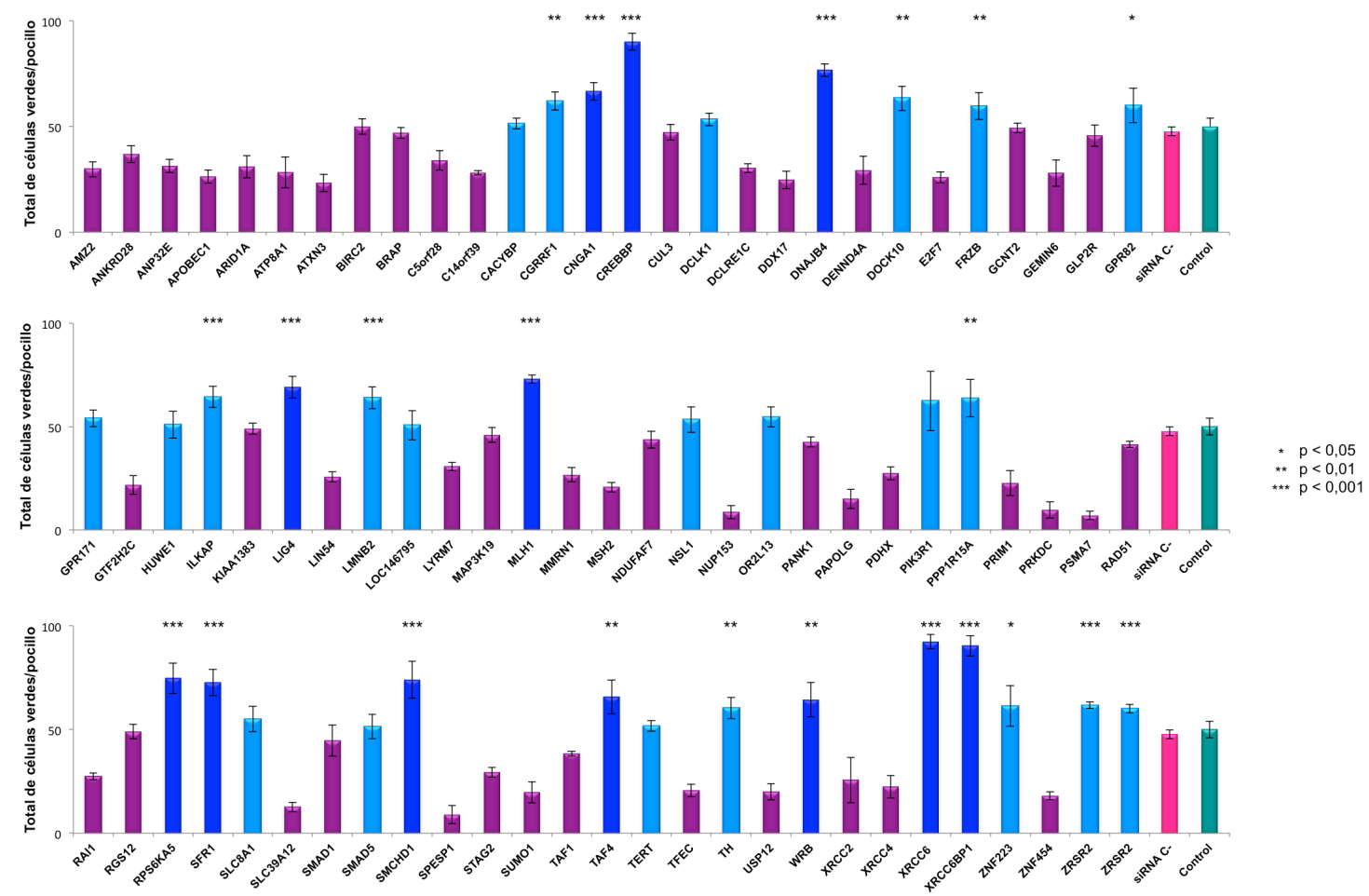

Figura 27. Resultados de la variación en la frecuencia de recombinación homóloga, al utilizar diferentes siRNAs junto con TALENs y rAAV. En verde se observa el control de TALENs + rAAV, en rosa el siRNA control negativo, en morado se observan los siRNAs que no producen aumento de $\mathrm{RH}$, y en azul los que sí producen aumento en $\mathrm{RH}$. Dentro de los que sí producen aumento en la frecuencia de RH observamos, los de menor aumento (azul claro) y los de mayor aumento y que fueron los elegidos para comprobar el efecto con otro siRNA dirigido contra el mismo gen (azul oscuro). Con $\left({ }^{*},{ }^{* *} \mathrm{y}^{* * *}\right)$ se indican aquellos siRNAs que dieron resultados estadísticamente significativos $(p<0,05, p<0,01$ y $p<0,001$, respectivamente). Con (I) se indica la desviación estándar de cada experimento.

Definidos los siRnAs que producen aumento en el número de células verdes recombinantes, respecto del control, se eligieron los 12 de mayor aumento (figura 28) para comprobar los resultados con siRNAs suplementarios. La importancia de diseñar nuevos siRNAs que tengan como diana el mismo gen, viene dada por la necesidad de corroborar que el efecto obtenido se deba realmente al silenciamiento del gen en estudio y no debido al silenciamiento de otros genes que presenten algún tipo de homología de secuencia con el siRNA. 

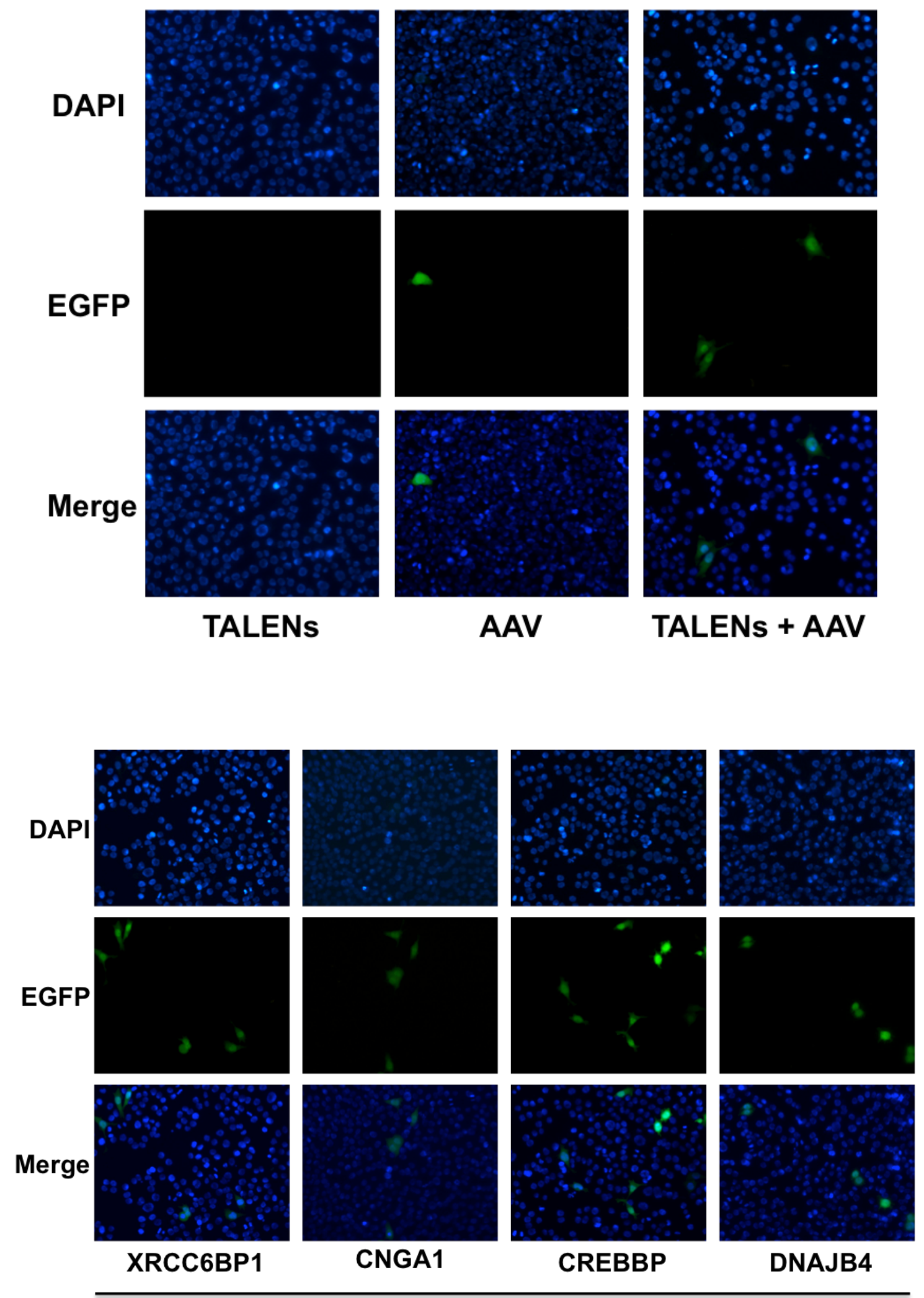

+TALENs+AAV 


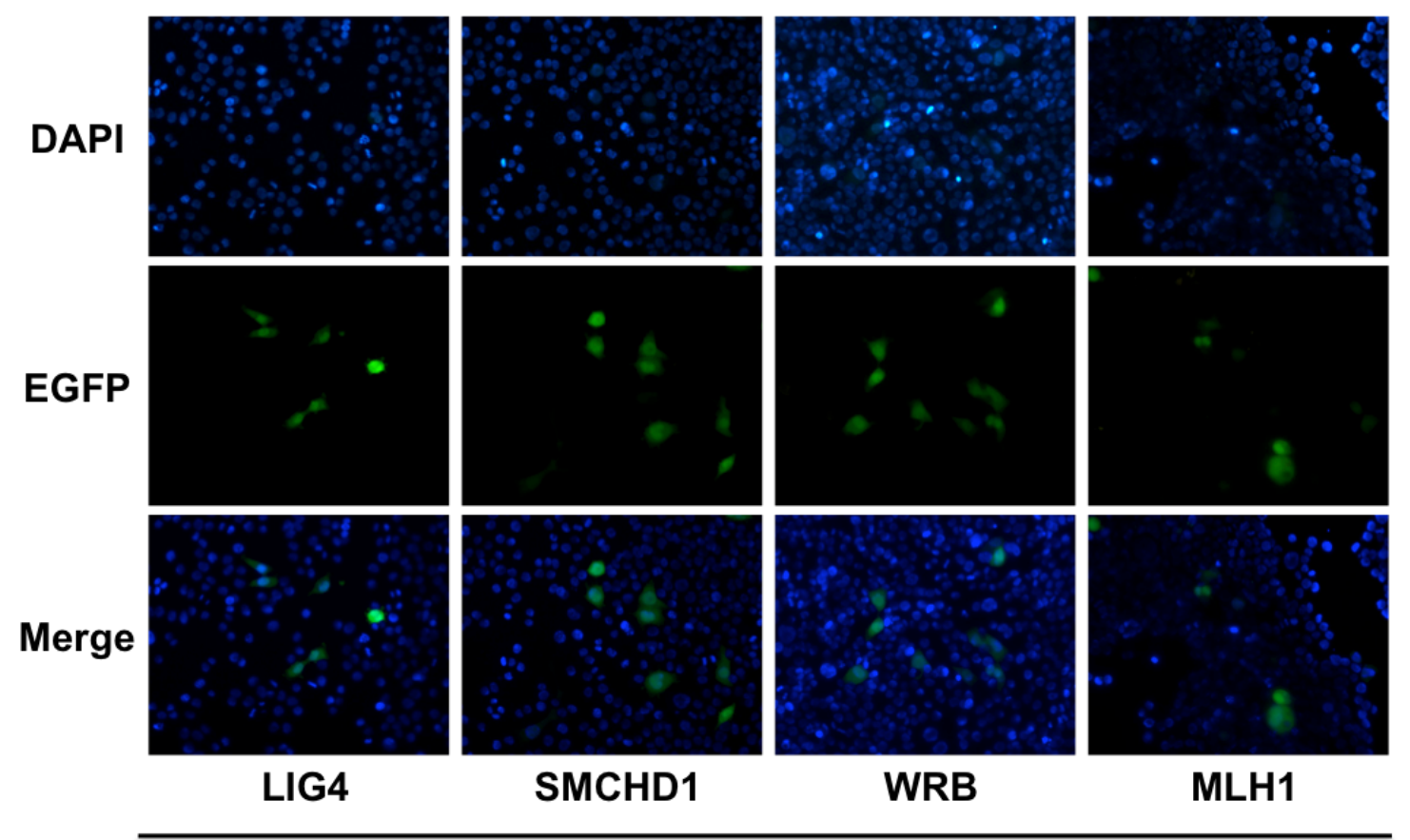

+TALENs+AAV

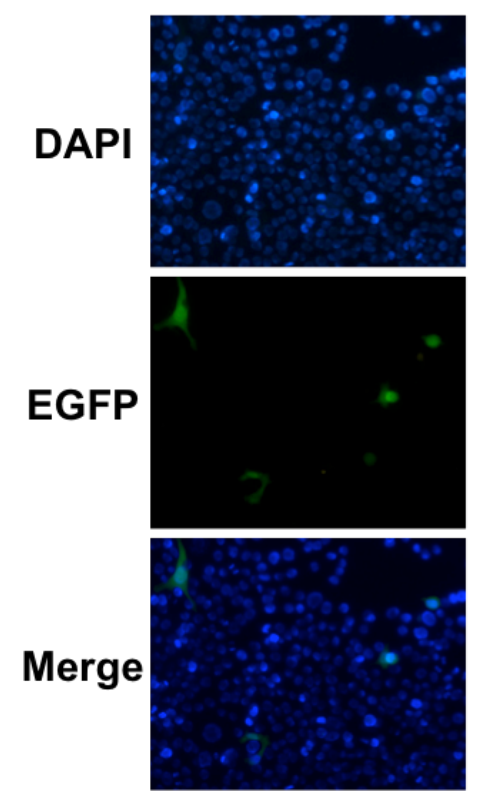

TAF4
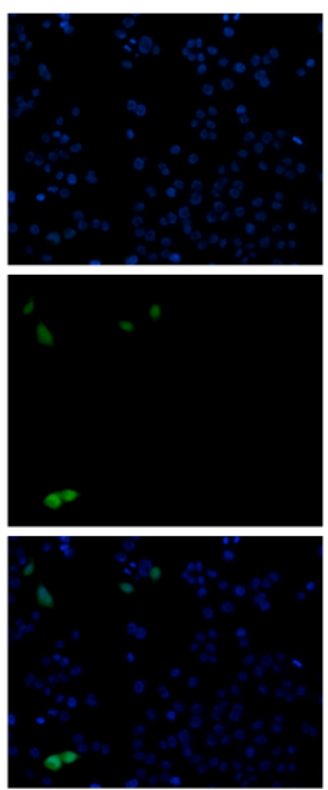

RPS6KA5
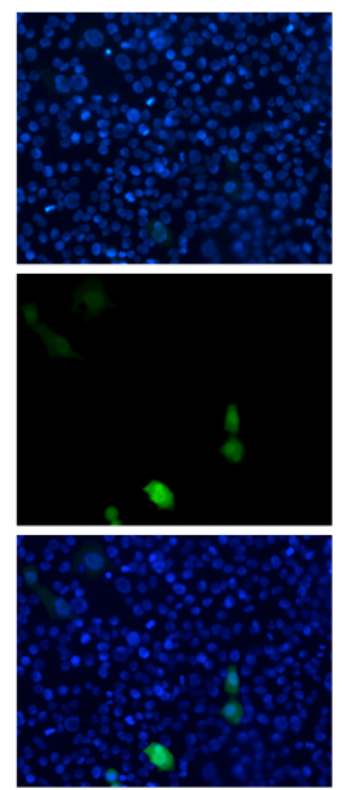

SFR1
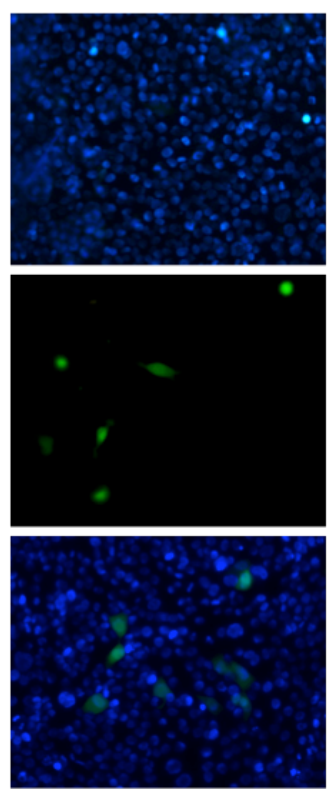

XRCC6

\section{+TALENs+AAV}

Figura 28. Microscopía de células HCT116-RCL. Aumento utilizado: 20X. En la parte superior de la figura se observan los núcleos de las células teñidos con DAPI. En la parte media, se observa la expresión de EGFP en las mismas células. Y, por último, en la parte inferior se puede observar una superposición de ambos colores. En la primera imagen se observan las células control de transfección (sólo con las TALENs), seguido por las células transducidas sólo con el virus $A A V-\triangle 5$-EGFP-donor, y finalmente, las células transfectadas con TALENs y posteriormente transducidas con el AAV. Las restantes imágenes corresponden a las transfecciones realizadas con los 12 siRNAs seleccionados màs efectivos. Estas células se transfectaron con las TALENs 24 horas después de los siRNAs, y otras 6 horas después, fueron transducidas con el AAV. 
En la figura 29 se puede comprobar la especificidad del efecto debido al silenciamiento génico producido por la presencia del correspondiente siRNA en la célula, ya que se han ensayado 2 siRNAs distintos dirigidos contra zonas diferentes del mismo gen, obteniéndose resultados similares con los distintos siRNAs.

El análisis estadístico de los datos obtenidos se realizó de igual manera que para la librería de siRNAs, descrito anteriormente en este mismo apartado. Los valores obtenidos durante el análisis estadístico pueden encontrarse en el apartado 3.3 del anexo.

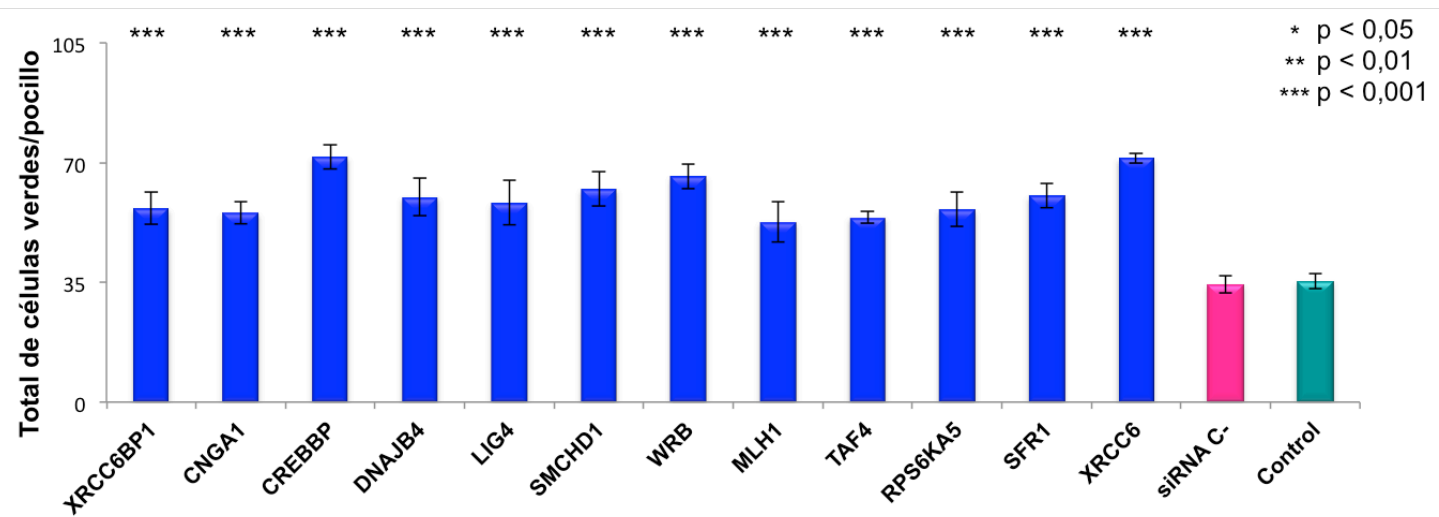

Figura 29. Resultados de la utilización de un segundo siRNA para comprobar que el silenciamiento génico se debió, efectivamente, a la presencia del siRNA correspondiente. En azul se observan aquellos siRNA que producen aumento de $\mathrm{RH}$, en rosa el siRNA control negativo $\mathrm{y}$, finalmente, en verde el control de TALENs $+\mathrm{rAAV}$. Con $\left({ }^{*}\right.$, $\left.{ }^{* *} \mathrm{y}{ }^{* * *}\right)$ se indican aquellos siRNAs que dieron resultados estadísticamente significativos $(p<0,05, p<0,01$ y $p<0,001$, respectivamente). Con (I) se indica la desviación estándar de cada experimento.

Las células tratadas con los siRNAs seleccionados, fueron analizadas para cuantificar la progresión del ciclo celular mediante tinción con yoduro de propidio y análisis por citometría de flujo, y los datos fueron analizados mediante utilización del software Cylchred perteneciente a la Universidad de Cardiff (figura 30). Cada uno de estos experimentos se realizó por triplicado. 
A

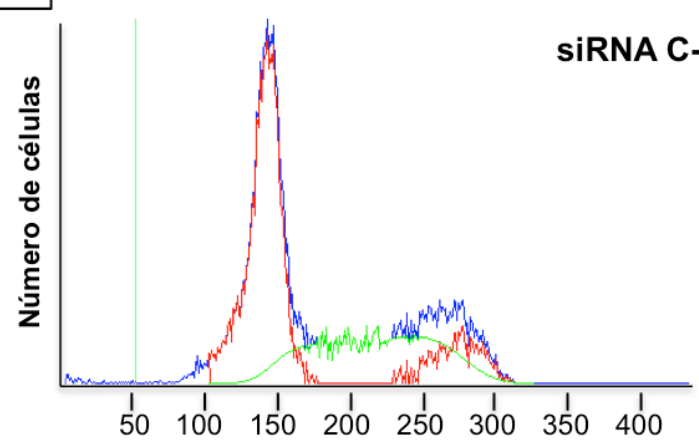

\section{B}

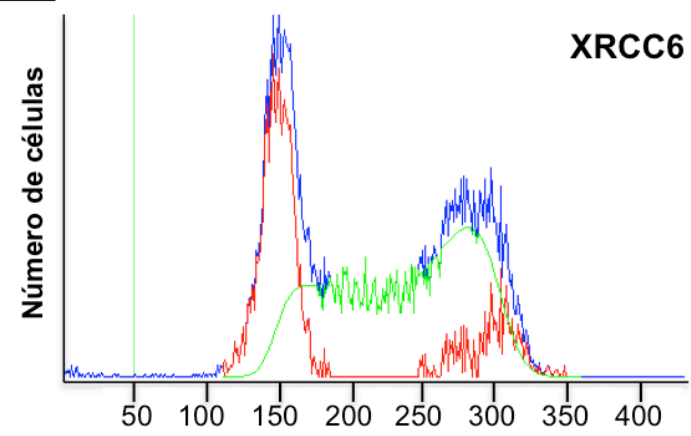

Figura 30. Ejemplo de análisis del ciclo celular utilizando un siRNA específico frente al siRNA control negativo. Los análisis se realizaron mediante la utilización del software Cylchred. En este análisis, en azul se observa el ciclo completo, en rojo las fases G1 y G2/M y en verde la fase S del ciclo celular. A. Se observa el ciclo celular en las células transfectada con uno de los siRNAs (XRCC6) en las cual se obtuvo un importante aumento en el número de células en fase S. B. Se observa la muestra de células donde se transfectó el siRNA control negativo, en el cual se obtuvo un importante aumento del número de células en fase $\mathrm{S}$.

El resultado de este análisis muestra un un aumento en la fase $S$ del ciclo celular, con varios de los siRNAs utilizados (tabla 2), lo cual podría explicar, al menos en parte, el aumento en la frecuencia de $\mathrm{RH}$.

\begin{tabular}{|c|c|c|c|}
\hline siRNA & $\mathrm{G} 1$ & $\mathrm{~S}$ & $\mathrm{G} 2$ \\
\hline CNGA1 & $29,8 \pm 4,6$ & $61,1 \pm 2,3$ & $9,0 \pm 2,8$ \\
\hline CREBBP & $25,1 \pm 3,1$ & $53,6 \pm 0,6$ & $21,3 \pm 2,0$ \\
\hline DNAJB4 & $33,1 \pm 0,2$ & $50,4 \pm 4,1$ & $16,5 \pm 3,3$ \\
\hline LIG4 & $27,2 \pm 2,9$ & $54,5 \pm 5,8$ & $18,4 \pm 5,6$ \\
\hline SMCHD1 & $31,9 \pm 1,5$ & $51,6 \pm 4,3$ & $16,5 \pm 1,1$ \\
\hline WRB & $22,4 \pm 4,7$ & $59,3 \pm 7,4$ & $18,3 \pm 4,5$ \\
\hline MLH1 & $18,3 \pm 5,3$ & $48,4 \pm 0,6$ & $33,3 \pm 3,1$ \\
\hline TAF4 & $27,4 \pm 5,4$ & $30,2 \pm 4,6$ & $42,3 \pm 3,3$ \\
\hline RPS6KA5 & $34,5 \pm 5,1$ & $43,4 \pm 6,9$ & $22,1 \pm 4,7$ \\
\hline SFR1 & $31,2 \pm 3,5$ & $52,0 \pm 5,5$ & $16,7 \pm 1,4$ \\
\hline XRCC6 & $27,1 \pm 5,5$ & $64,0 \pm 3,7$ & $8,9 \pm 3,2$ \\
\hline siRNA C- & $33,2 \pm 4,3$ & $46,2 \pm 0,6$ & $20,6 \pm 0,9$ \\
\hline Control & $36,0 \pm 2,5$ & $57,8 \pm 3,1$ & $6,3 \pm 1,0$ \\
\hline
\end{tabular}

Tabla 2. Resultados obtenidos en el análisis del ciclo celular utilizando el software Cylchred. En la tabla se observan los diferentes siRNAs utilizados y el porcentaje de células hallado en cada una de las fases del ciclo celular a las 24 horas de realizar la transfección de los respectivos siRNAs. 
Finalmente, hemos ensayado diversas combinaciones de algunos siRNAs que han sido más eficientes en inducir $\mathrm{RH}$, para estudiar un posible efecto sinérgico de ambas dichas combinaciones (figura 31). El análisis estadístico de los datos obtenidos con estas combinaciones, se llevó a cabo de la misma forma que para la librería de siRNAs, descrito anteriormente en este mismo apartado. Los valores obtenidos durante el análisis estadístico pueden encontrarse en los apartado 3.4, 3.5 y 3.6 del anexo.

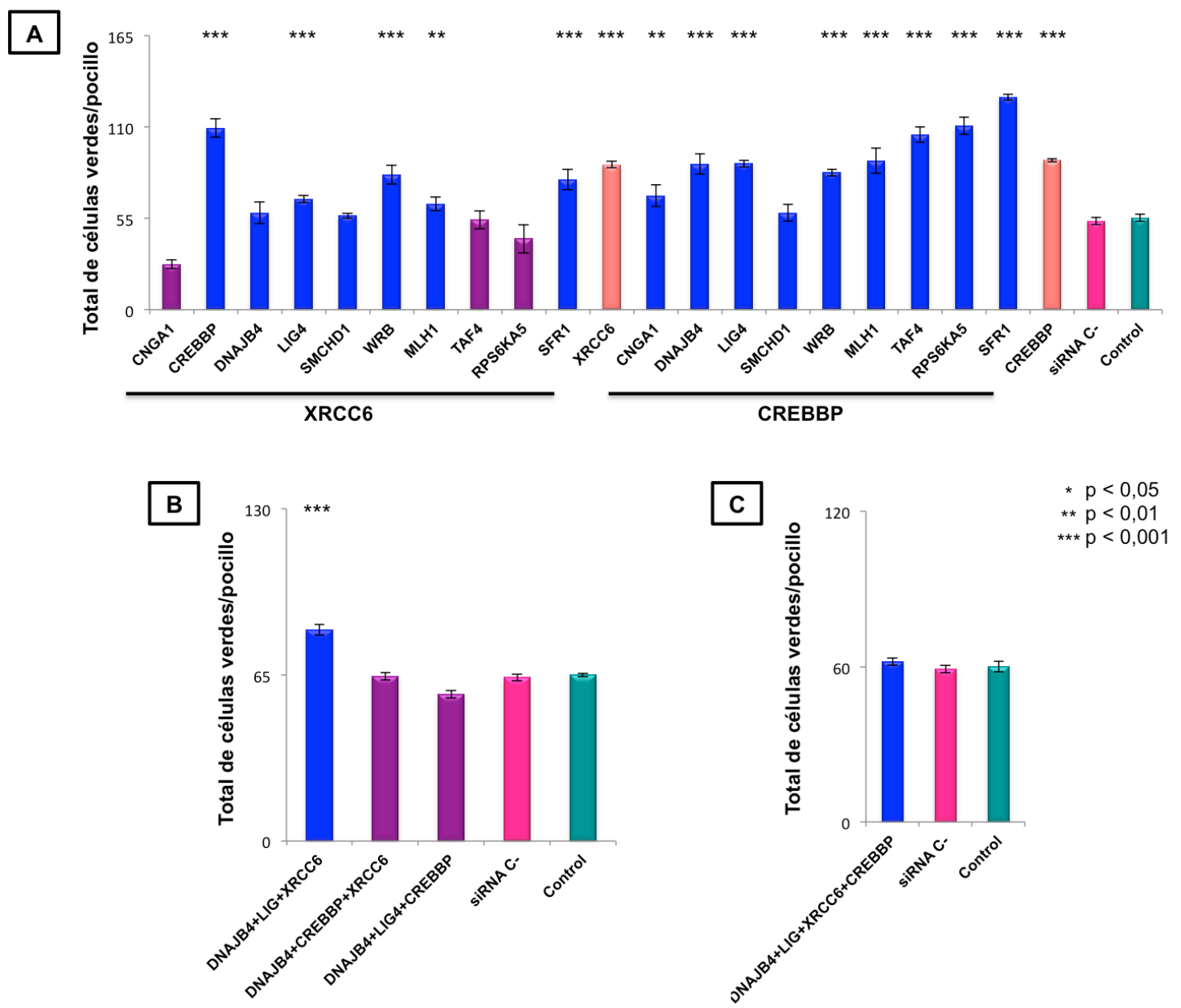

Figura 31. Resultados obtenidos combinando diferentes siRNAs. A. Combinación de dos siRNAs. En naranja se observan los dos siRNAs que más aumento de RH dieron, de manera individual. B. Combinación de tres siRNAs. C. Combinación de cuatro siRNAs. En morado se observan aquellos que no producen aumento de RH, en azul los que sí producen aumento, en rosa el siRNA control negativo y, finalmente, en verde el control de TALENs $+\operatorname{rAAV}$. Con $\left({ }^{*},{ }^{* *} \mathrm{y}\right.$ $\left.{ }^{* * *}\right)$ se indican aquellos siRNAs que dieron resultados estadísticamente significativos $(p<0,05, p<0,01$ y $p<0,001$, respectivamente). Con (I) se indica la desviación estándar de cada experimento.

Como se observa en la figura 31.A hemos obtenido una combinación de dos siRNAs, CREBBP + SFR1, con la cual se obtiene un aumento en el número de células verdes de más del doble con respecto al control. También se ha visto que la mayoría de las combinaciones usadas produjeron diferentes niveles de aumento del número de 
células verdes, con excepción de tres de ellas (CNAGA1 + XRCC6, TAF4 + XRCC6 y RPS6KA5 + XRCC6). En cuanto a las combinaciones de tres siRNAs (figura 31.B), se observa que sólo una de las combinaciones (DNAJB4 + LIG4 + XRCC6) da un aumento en el número de células verdes, y que este aumento es muy leve, comparado con el aumento obtenido en otros casos. Finalmente, en las combinaciones de cuatro siRNAs (figura 31.C) si bien se obtiene un aumento, este es mínimo comparado con los aumentos obtenidos en los casos anteriores. Las combinaciones se llevaron a cabo de manera de combinar aquellos siRNAs que han dado mayor aumento en la frecuencia de $\mathrm{RH}$ en forma individual, sin embargo, restan aún por probar muchas más combinaciones.

\section{Generación, corrección y transdiferenciación de la línea celular WASP-KO.}

\subsection{Diseño y construcción de los vectores p-AAV-MCS-WASP-KO y p-AAV-MCS-WASP-wt.}

En este trabajo nos propusimos mejorar la frecuencia de modificación génica dirigida en fibroblastos humanos, para poder aplicar estas condiciones en la corrección de mutaciones de células derivadas de pacientes con enfermedades monogénicas de difícil manejo clínico, como es el síndrome de Wiskott-Aldrich (WAS). Es así que, con el objetivo futuro de poder corregir células de pacientes enfermos de WAS, y a falta de poder contar con células de dichos pacientes, hemos decidido crear una línea celular en fibroblastos humanos en los cuales se introduce una mutación en el gen que codifica para WASp. Para ello, hemos tenido en cuenta los resultados obtenidos en el uso de diferentes siRNAs que hacen posible la aplicación de estos, como una manera de mejorar la RH tanto en líneas celulares como en células extraídas de pacientes que sufren de WAS o de cualquier otra enfermedad monogénica.

Para poder construir la línea WASP-KO se diseñaron y construyeron en paralelo dos plásmidos ( $p$-AAV-MCS-WASP-wt y p-AAV-MCS-WASP-KO) que permitieran, uno de ellos, introducir en el locus de WAS una mutación que impida la producción de la proteína, mientras que el otro, será el responsable de recuperar la función del gen.

Para llevar a cabo la construcción del vector p-AAV-MCS-WASP-wt (figura 32.A), se amplificaron por PCR dos fragmentos del gen WAS. El primero de ellos, de $1.1 \mathrm{~kb}$, que corresponde a la secuencia de los exones $3,4,5$ y 6 (Arm 1) y el segundo, de $1.5 \mathrm{~kb}$, que corresponde al exón 7 (Arm 2). Los fragmentos se purificaron y digirieron con 
Sall/Notl y EcoRI/Notl, respectivamente. En paralelo, se obtuvo un fragmento de 1.6 $\mathrm{kb}$ que contiene un casete de resistencia a blasticidina, mediante digestión con Sall/EcoRI del plásmido pBS-Blasticidin generado en nuestro laboratorio. Los tres fragmentos así obtenidos, fueron aislados mediante electroforesis en gel de agarosa y, posteriormente, se ligaron en el plásmido pAAV-MCS, previamente digerido con Notl. Las colonias bacterianas obtenidas se amplificaron mediante minipreps, y se comprobaron como sigue (figura 32.B):

1. Notl: 2.900 bp y 4.200 bp.

2. EcoRI/Sall: 1.600 bp y $5.500 \mathrm{bp}$.

3. Notl/EcoRI: 1.500 bp, 2.700 bp y 2.900 bp.

4. Notl/Sall: 1.100 bp, 2.900 bp y 3.100 bp.

\section{A}

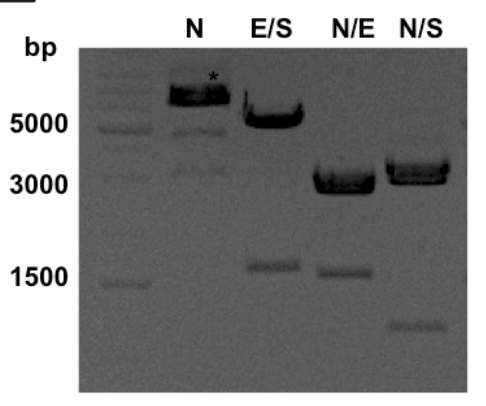

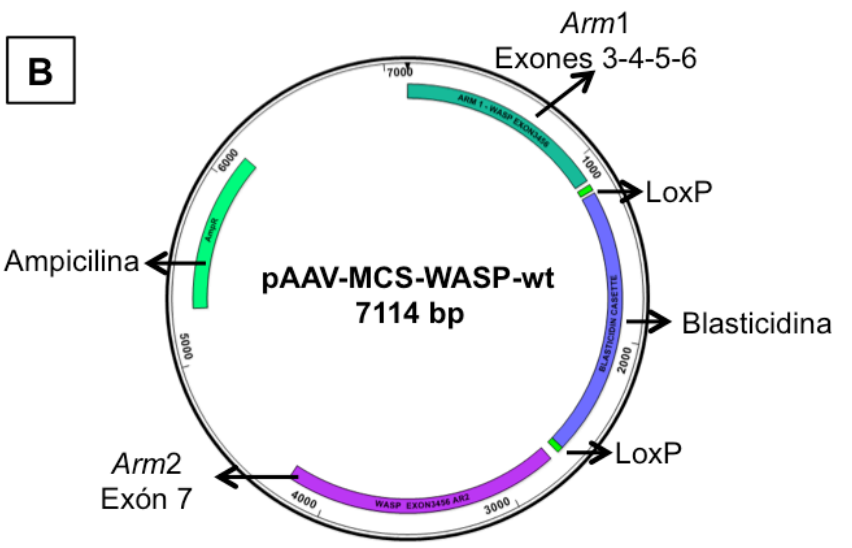

Figura 32. p-AAV-MCS-WASP-wt. A. Se observan las digestiones de comprobación del plásmido, realizadas con Notl, EcoRI/Sall, Not/EcoRI, y Notl/Sall, y dónde se obtienen los pesos esperados. (*) Indica una digestión parcial del vector. B. Se observa el mapa del plásmido construido.

En paralelo se construyó otro vector (p-AAV-MCS-WASP-KO), similar al anterior, pero que posee una mutación en el exón 4. Para ello se utilizó el Arm 1 obtenido previamente, el cual se ha subclonado en el vector pBluescript II KS +/-, para llevar a cabo una mutagénesis dirigida. La finalidad de dicha mutagénesis fue la de introducir una adenina $(A)$, con el fin de generar un codón stop en la posición 168, en el exón 4. Una vez introducida esta mutación en el DNA, el gen WAS no es capaz de expresarse. Esta mutación se ha descrito ya en pacientes de WAS, en los que se ha demostrado ausencia de la proteína.

Una vez obtenido el plásmido a partir de las bacterias transformadas, este fue secuenciado comprobando así la introducción de la mutación deseada. 
Una vez comprobada la mutación, el Arm 1 fue extraído del plásmido en donde se realizó la mutagénesis mediante digestión con las enzimas de restricción Notl/Sall y utilizado para la construcción del vector p-AAV-MCS-WASP-KO (figura 33). Es decir, este vector es exactamente igual al vector p-AAV-MCS-WASP-wt, anteriormente descrito, excepto que es portador de la mutación que le hemos introducido.

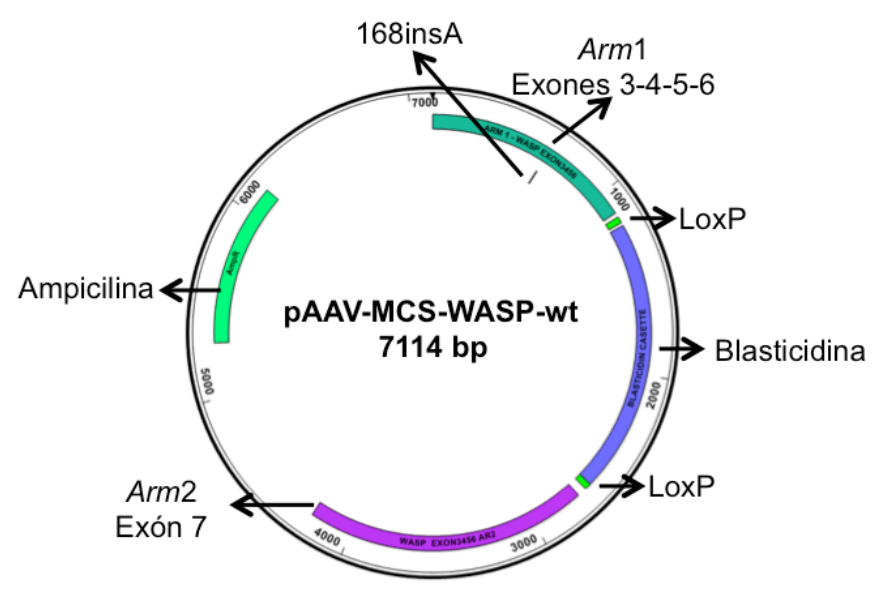

Figura 33. p-AAV-MCS-WASP-KO. En la figura se observa el mapa del plásmido construido. 168insA indica la mutación generada, mediante la cual se ha introducido una adenina que genera un codón stop en la posición 168 (exón 4 del gen WAS).

\subsection{Construcción de los virus AAV-WASP-KO y AAV-WASP-wt.}

Una vez que hemos construido los dos plásmidos mencionados en el apartado anterior, hemos obtenido los virus adenoasociados recombinantes, AAV-WASP-wt y AAV-WASP-KO. Como se describe en la sección 2.3.5 de materiales y métodos, para los producción de los rAAV utilizamos las células empaquetadoras, AAV293. Poco después de realizar la co-transfección de los 3 plásmidos ( $p-A A V-R C$, pHelper y pAAV-MCS-WASP-wt o p-AAV-MCS-WASP-KO), el efecto citopático del virus se fue haciendo cada vez más evidente (figura 17). Transcurridas 72 horas de la transfección, las células fueron despegadas del soporte mediante raspado, y sometidas a 4 ciclos de congelación/descongelación para facilitar la lisis de las mismas y obtener, así, las partículas virales en suspensión.

Finalmente, los virus AAV-WASP-wt y AAV-WASP-KO fueron cuantificados mediante PCR cuantitativa en tiempo real, utilizando los primers ITR S e ITR AS, específicos de la región ITR. En paralelo se realizó una curva patrón, a partir de cantidades conocidas del plásmido pAAV-MCS, el cual contiene también las secuencias ITRs. Se obtuvieron títulos en el rango entre $10^{8}-10^{9}$ partículas virales $/ \mathrm{mL}$. 


\subsection{Diseño y construcción de nickasas CRISPR/Cas9 para WASp.}

Con el objeto de aumentar la frecuencia de recombinación homóloga entre el DNA de la célula en estudio y el DNA donante que hemos de introducir, hemos diseñado y construido una pareja de nickasas CRISP/Cas9, que favorecerán la inserción del DNA donante en el DNA genómico de la célula.

Para la construcción de la pareja de nickasas, se tuvieron en cuenta las referencias bibliográficas existentes al respecto, y según ellas, seleccionamos 2 secuencias de 20 nucleótidos separadas entre sí por otros 30 nucleótidos. Dichas secuencias se encuentran al final del Arm 1, en el intrón 6. Con estas dos secuencias se obtuvieron los primers CRISPR-WASP1 S, CRISPR-WASP1 AS, CRISPR-WASP2 S y CRISPRWASP2 AS, que después de ser alineados, dos a dos, in vitro, fueron utilizados para construir cada una de las nickasas (figura 34). Cada pareja de primers alineados se subclonó en el plásmido pX335 el cual contiene una Cas9 mutante (D10A), actuando así como una nickasa de DNA, motivo por el cual se necesita una pareja de ellas para poder llevar a cabo un solo corte (nick) en cada una de las hebras del DNA.

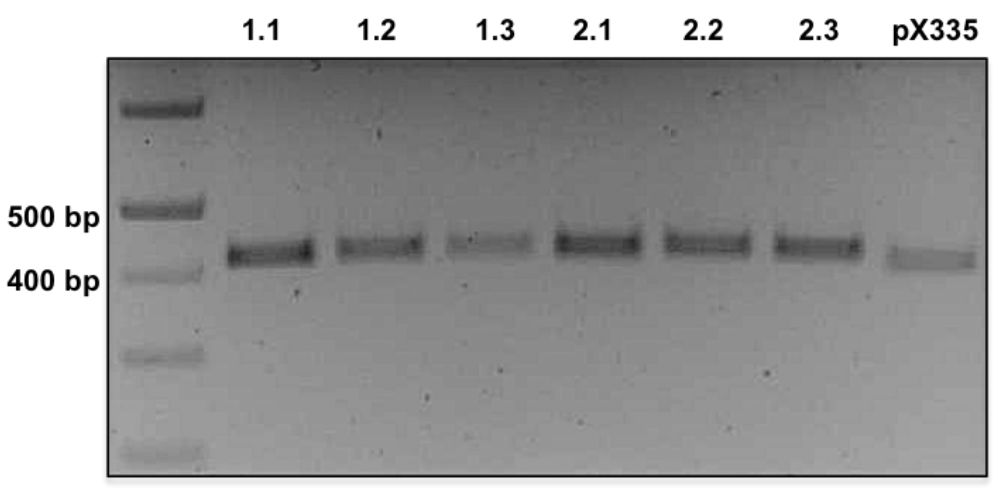

Figura 34. Digestión con Ndel de los plásmidos obtenidos de ligar el pX335, con cada par de primers, previamente anillados. Los carriles 1.1, 1.2 y 1.3 corresponden a tres clonas diferentes de la primera pareja de primers (CRISPRWASP1 S y CRISPR-WASP1 AS). Los carriles 2.1, 2.2 y 2.3 pertenecen a tres clonas diferentes de la segunda pareja de primers (CRISPR-WASP2 S y CRISPR-WASP2 AS). En el último carril, pX335, se observa la banda correspondiente al plásmido vacío. Las bandas pertenecientes a la ligación tienen un peso de 420 bp, mientras que la banda correspondiente al plásmido vacío es de $380 \mathrm{bp}$.

\subsection{Generación de líneas celulares WASP-KO.}

Se han generado células WASP-KO utilizando dos tipo celulares diferentes y diferentes protocolos de modificación génica dirigida.

Primero, se quiso ensayar si el método de manipulación génica dirigida que probamos anteriormente en nuestra línea reportera es también efectivo cuando se utilizan células primarias como es el caso de los fibroblastos humanos, los cuales no expresan la 
proteína WASp debido a que esta se expresa solo en células de estirpe hematopoyética. Es así que se procede a la generación de fibroblastos WASP-KO, utilizando rAAVs junto con diferentes siRNAs, que demostraron previamente un efecto en el aumento de la frecuencia de RH en la línea celular reportera HCT116-RCL.

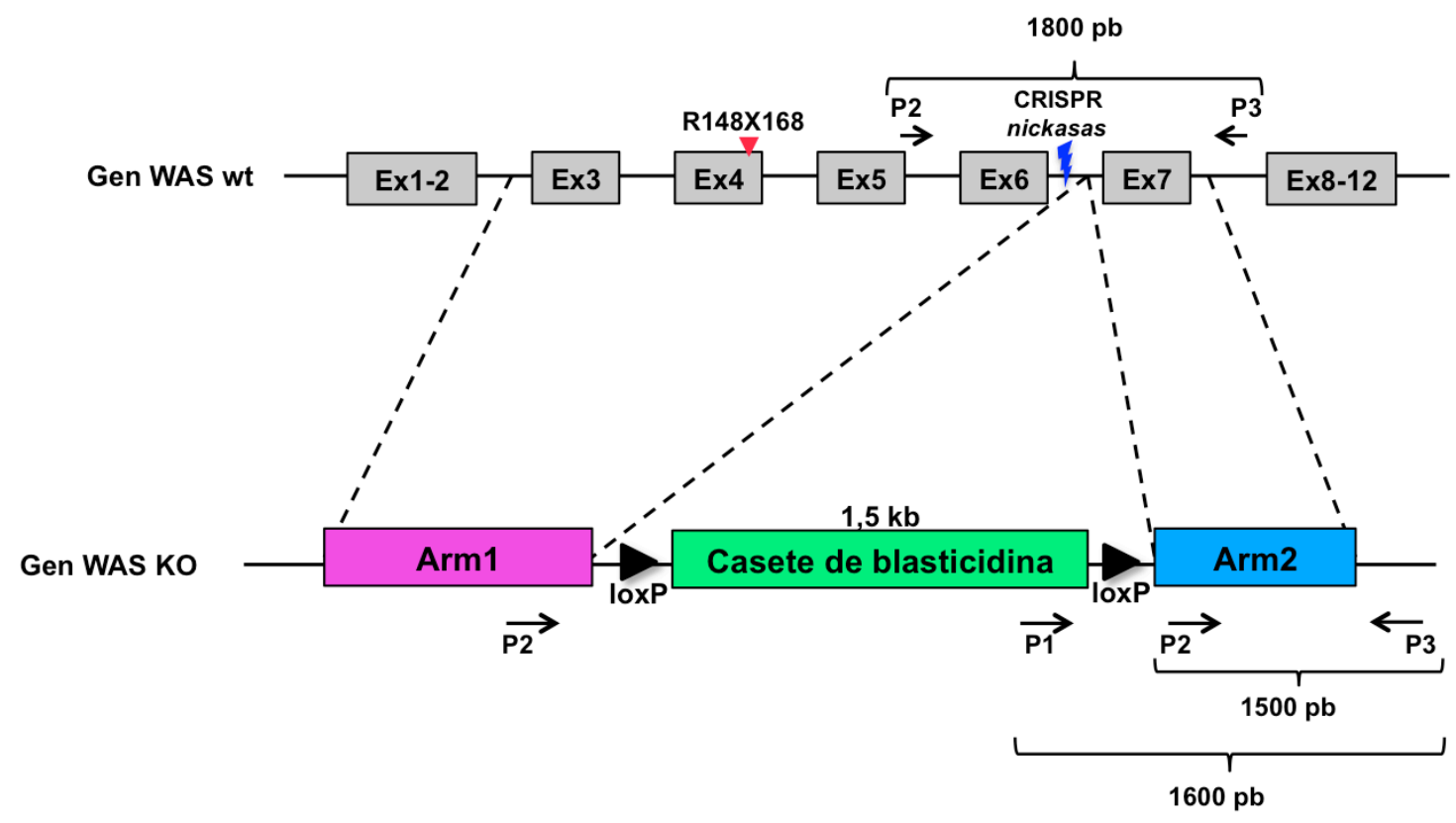

Figura 35. Esquema del gen WAS wt y del gen modificado. En la parte superior de la figura se puede observar el gen sin modificaciones y las posiciones en dónde se introdujo la mutación, y dónde ejercerán su acción las nickasas. En la parte inferior se ve el gen modificado. P1 (WASP S1.1 S), P2 (WASP S1.2 S) y P3 (WASP S1 AS) corresponden a los primers utilizados para realizar las PCRs de screening y los tamaños que se obtienen de cada amplificación.

\section{Las células WASP-KO obtenidas de esta manera fueron analizadas posteriormente} mediante PCRs (figura 36).

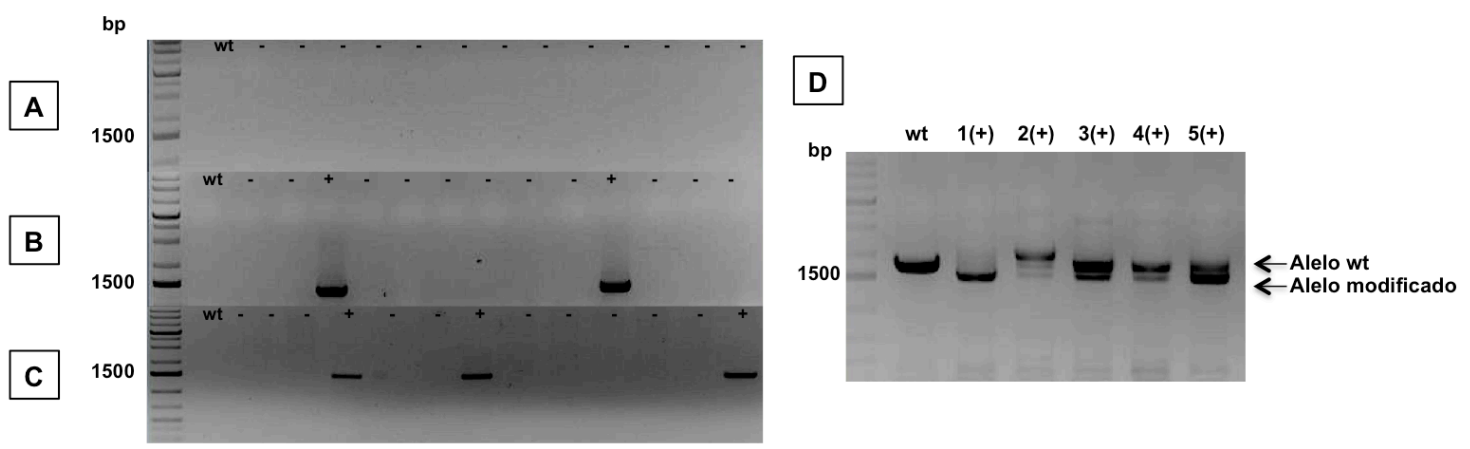

Figura 36. PCRs realizadas con diferentes clonas de fibroblastos, a partir de una dilución límite. Las PCRs A, B y C han sido realizadas con los primers WASP S1.1 S y WASP S1 AS, como el primer WASP S1.1 S se encuentra en el casete de blasticidina, en las clonas wt no se esperan amplificados. En D, las PCRs se realizaron con la pareja WASP S1.2 S y WASP S1 AS. A. PCR de las clonas obtenidas en la placa correspondiente a las células nucleofectadas con siRNA control. En ella podemos ver que en 14 clonas, no hemos obtenido positivas. B. PCR de las clonas obtenidas en la placa nucleofectada con CREBBP. De 14 clonas se han obtenido dos positivas (+). C. PCR de las clonas de células nucleofectadas con CREBBP+SFR1. En este caso se obtuvieron 3 positivas (+) en 14 clonas analizadas. D. PCRs de las 5 clonas positivas $(+)$ obtenidas en las PCRs anteriores. En la imagen observamos en el primer carril la banda de $1.8 \mathrm{~kb}$ correspondiente al alelo wt, proveniente de una clona wt. En el pocillo siguiente podemos observar una banda de $1.5 \mathrm{~kb}$, correspondiente a una clona pura de células que sólo contienen el alelo modificado. En los restantes carriles observamos mezcla de células, ya que podemos observar ambas bandas. 
Habiéndose analizado 64 pocillos, de una placa de 96, de cada una de las 3 condiciones (CREBBP, CREBBP/SFR1 y siRNA control) se obtuvieron 9 muestras positivas para la combinación CREBBP/SFR1, 6 para CREBBP y ninguna en las muestras analizadas para el control. A partir de esto, según se explica en el apartado 2 de esta sección, se calcula la frecuencia de $\mathrm{RH}$ obteniéndose $0.25 \%$ para CREBBPISFR 1 y $0.15 \%$ CREBBP.

Los fibroblastos WASP-KO así obtenidos fueron posteriormente corregidos para recuperar la expresión de WASp, tras lo cual fueron transdiferenciados a células multipotentes hematopoyéticas $\mathrm{CD}_{4} 5^{+}$, cuyos resultados se analizaran en los apartados 8.5 y 8.7 de esta sección, respectivamente.

En experimentos paralelos, se intentó generar una línea KO para WASp usando como modelo la línea celular Jurkat. Se ha elegido esta línea primero porque deriva de un varón, y en consecuencia solo tiene un cromosoma $X$, siendo más fácil la generación de un KO para WASp (el proceso de modificación génica debe emplearse sólo una vez) y además por ser de estirpe $T$, con lo cual se puede examinar la expresión de WASp fácilmente mediante Western Blot, lo que no sucede con los fibroblastos, que no expresan la proteína.

En la figura 37, pueden observarse las PCRs realizadas una vez obtenidas las células Jurkat WASP-KO. Se puede observar la mayor efectividad obtenida al utilizar este sistema en comparación con fibroblastos primarios, ya que hemos obtenido, directamente y sin necesidad de realizar diluciones límites, clonas KO puras.

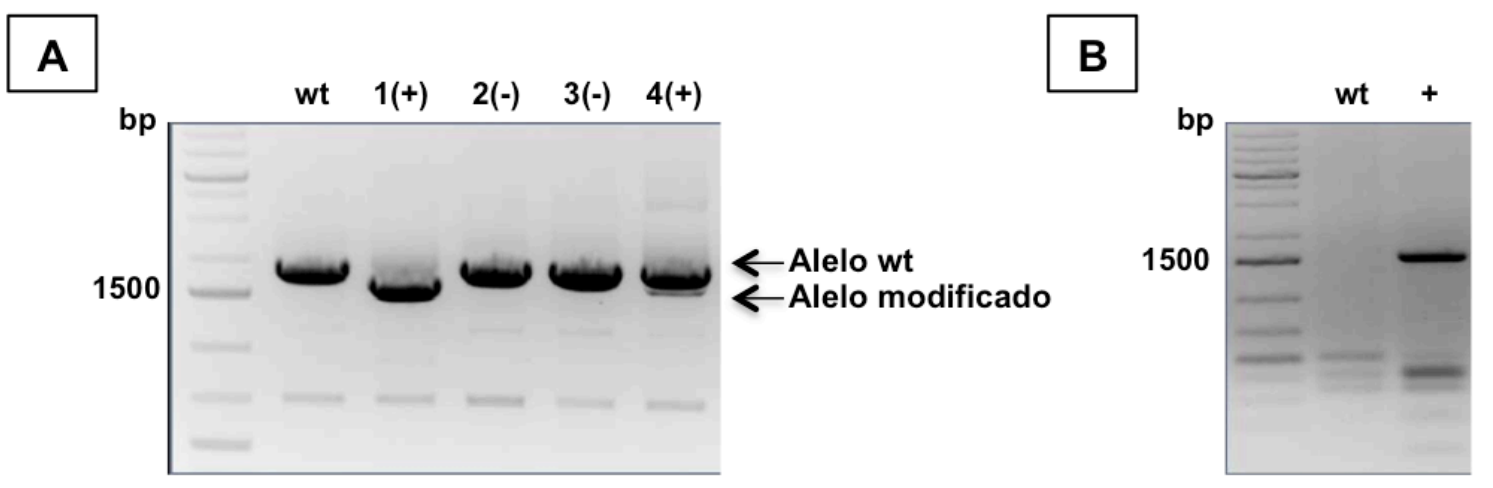

Figura 37. PCRs realizadas con diferentes clonas de jurkat. Las PCRs en A han sido realizadas con los primers WASP S1.2 S y WASP S1 AS; mientras que las PCRs en B se realizaron con la pareja WASP S1.1 S y WASP S1 AS. A. En la imagen se observa en el primer carril la banda de $1.8 \mathrm{~kb}$ correspondiente al alelo wt, proveniente de una clona de Jurkat wt. En el segundo carril podemos observar una banda de $1.6 \mathrm{~kb}$, correspondiente a una clona pura de células que sólo contienen el alelo modificado. Los carriles 3 y 4 corresponden a células que contienen solo el alelo wt. En el carril 5 se observan dos bandas, una correspondiente al alelo wt y otra al alelo modificado. B. En esta imagen se observa una PCR de células wt y la del carril 2 de la PCR anterior. En el primer carril no hay amplificado ya que uno de los primers se encuentra en el casete de blasticidina. 
Se calculó la frecuencia de $\mathrm{RH}$, que fue de alrededor de $1 \%$.

Con la clona pura de células Jurkat que contienen el alelo KO se realizó, posteriormente, un western blot según se describió en la sección de materiales y métodos, apartado 2.1.9. Para comprobar la ausencia de proteína WASp hemos utilizado un anticuerpo primario policlonal $\alpha$-WASp, llamado K-374, que reconoce en el extremo C-terminal de la proteína. Como anticuerpo secundario hemos utilizado un $\alpha$ IgG de conejo, marcado con peroxidasa de rábano (figura 38).

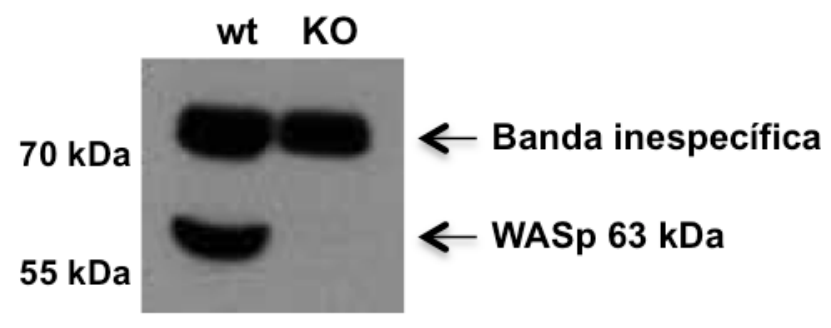

Figura 38. Análisis por western blot de WASp en células Jurkat. En el primer carril se observa la presencia de la proteína de $63 \mathrm{kDa}$ en las células Jurkat wt. En el segundo carril se observa la ausencia de WASp en la línea celular Jurkat-WASP-KO.

El resultado del western blot evidencia la ausencia de la proteína en la línea de Jurkat WASP-KO y su presencia en la línea wt, lo cual concuerda con los resultados obtenidos previamente en las PCRs.

\subsection{Tratamiento de la línea celular WASP-KO con CRE recombinasa y posterior corrección de la misma.}

Hasta ahora, como se ha explicado en el resultado anterior, disponemos de varios clones de fibroblastos WASP-KO. Estas células poseen una mutación ya descrita en pacientes de WAS que no expresan dicha proteína (Jin et al., 2004). Es decir, los clones son equivalentes a fibroblastos obtenidos de pacientes enfermos. Es por ello que nos propusimos corregir dicha mutación y comprobar que se recupera así la expresión de WASp. Esto requiere una segunda modificación génica dirigida en dichas células usando el método ya descrito, pero en este caso se debió utilizar el vector donante AAV-WASP-wt. Para poder rastrear los clones corregidos, necesitamos primero eliminar el casete de selección de blasticidina, presente en los fibroblastos KO, motivo por el cual se utiliza la proteína TAT-NLS-CRE recombinante, cuya obtención se describe en el apartado 2.2.3 de la sección de materiales y métodos. 
La acción de TAT-NLS-CRE se llevó a cabo en las condiciones de cultivo habituales, tras lo cual se sembraron las células a dilución límite con objeto de obtener clonas individuales donde la deleción del casete de resistencia a antibiótico haya tenido lugar. Para poder determinar los clones que perdieron el casete de blasticidina y cuáles no, se analizaron las clonas mediante PCR (figura 39). Las PCRs se realizaron utilizando los primers WASP S1.1 S y WASP S1 AS, que amplifican un producto de alrededor de $1.6 \mathrm{~kb}$ sólo si el casete de blasticidina no ha sido escindido.

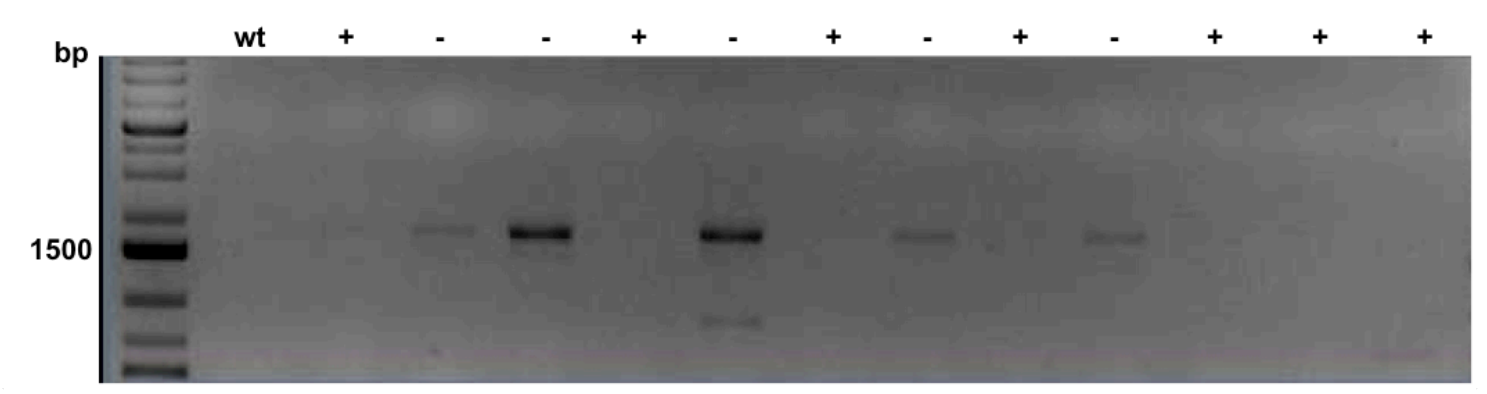

Figura 39. Análisis por PCRs de las clonas tratadas con CRE recombinasas, utilizándose los primers WASP S1.1 S y WASP S1 AS. Por lo tanto, las clonas que no tienen el casete de blasticidina no amplifican y son positivas (+) para la remoción del casete.

Habiéndose comprobado, en más del $50 \%$ de los clones analizados, la ausencia del casete de resistencia, se utilizó uno de estos clones para corregir la mutación introducida en el gen WAS. Dicho clon fue transfectado mediante nucleofección con la mezcla de siRNAs CREBBP/SFR1 utilizada anteriormentes por su importante aumento en la frecuencia de $\mathrm{RH}$, y posterior infección con el virus AAV-WASP-wt a una MOI de $10^{3}$.

Siguiendo el protocolo habitual, se obtienen clones individuales que se analizan mediante PCR, con los primers WASP S1.1 S y WASP S1 AS. Si ocurre amplificación significa que las células han sido corregidas y ahora portarán un gen WAS normal (figura 40).

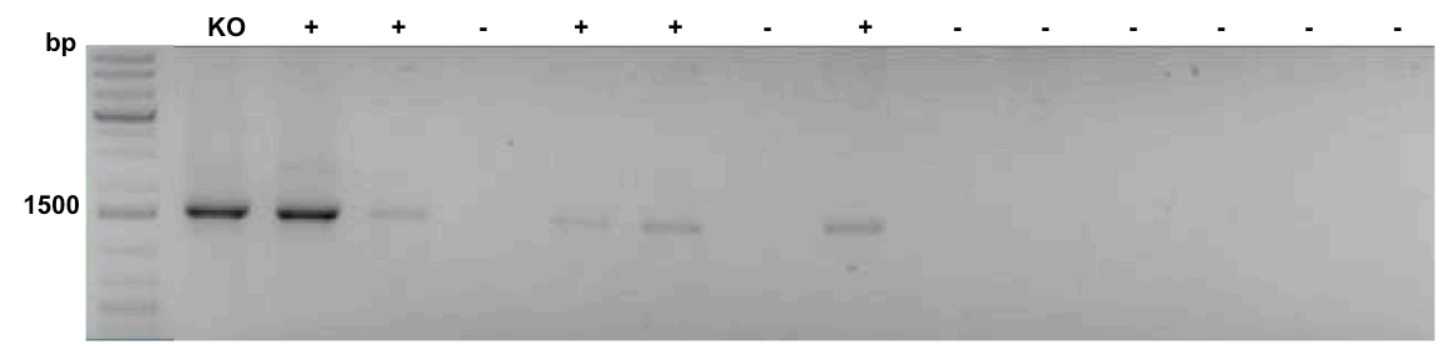

Figura 40. Análisis por PCRs de las clonas transducidas con el virus AAV-WASP3456-wt, utilizándose los primers WASP S1.1 S y WASP S1 AS. Las clonas que contienen el casete de blasticidina amplifican una banda de $1.6 \mathrm{~kb}$ y son positivas (+) para la corrección de la mutación. 
Calculamos una frecuencia de $\mathrm{RH}$ alrededor del $0.8 \%$, lo cual se aproxima a la obtenida anteriormente para la línea KO.

\subsection{Obtención y cuantificación del lentivirus LV-Oct4.}

Para la obtención del LV-Oct4 se utilizaron las células empaquetadoras 293-FT, sobre las que se co-transfectaron los 3 plásmidos comerciales pSin-EF2-Oct4-Pur, psPAX2 y pMD2.G. EI LV fue, finalmente, obtenido por ultracentrifugación del sobrenadante del cultivo, según se explica en el apartado 2.4.8 de la sección de materiales y métodos.

El cálculo del título viral obtenido se realizó mediante RT-qPCR del cDNA obtenido a partir del vector lentiviral. Se realizó el análisis por triplicado, utilizando una curva patrón a partir de cantidades conocidas del plásmido pSin-EF2-Oct4-Pur. El resultado es de un título viral de $8 \times 10^{7}$ copias $/ \mathrm{mL}$, el cual se ajusta a los títulos promedios obtenidos por otros autores $\left(10^{6}-10^{8}\right.$ partículas virales $/ \mathrm{mL}$. Tang et al 2015).

\subsection{Transdiferenciación de fibroblastos a células hematopoyéticas.}

La conversión de fibroblastos se realizó siguiendo el protocolo establecido por Szabo et al., 2010, en donde se demuestra que es posible obtener células de estirpe hematopoyética a partir de fibroblastos mediante transdiferenciación. La transdiferenciación, es el proceso mediante el cual una célula somática de determinada estirpe se convierte en una célula somática de estirpe distinta sin pasar primero por un estado de célula progenitora pluripotente.

La razón que nos llevó a ensayar este protocolo fue la necesidad formal de demostrar que una vez corregida la mutación en el gen WAS, la capacidad de dichas células de transdiferenciarse a células hematopoyética no se ve afectada, y que además, las células obtenidas por este método son capaces de expresar WASp normalmente.

Para llevar a cabo este procedimiento se utilizó una placa de 12 pocillos, cuyos pocillos se cubrieron con matriz geltrex. Una vez retirada la matriz, se sembraron los fibroblastos corregidos (Fibs-WASP+). A las 24 horas de haber sembrado las células, se realizó la transducción con el LV-Oct4 a una $\mathrm{MOI}$ de $10^{2}$. Veinticuatro horas después, se retiró el medio de transducción y se añadió FCM suplementado con 300 $\mathrm{ng} / \mathrm{mL}$ de SCF y $300 \mathrm{ng} / \mathrm{mL}$ de Ilt3L. Se utilizaron estas dos quimiocinas, ya que se demostró que son necesarias para la diferenciación in vitro de células madres 
pluripotentes a precursores hematopoyéticos. Este medio suplementado, se usó durante todo experimento, cambiando cada 2 días el medio, hasta el día 37.

A partir del cuarto día de realizada la transducción con el lentivirus, comenzaron a observarse cambios en la morfología de los fibroblastos, que comienzan a agruparse para formar agregados de células redondeadas, los cuales se observan mejor al séptimo día post-transducción (figura 41).
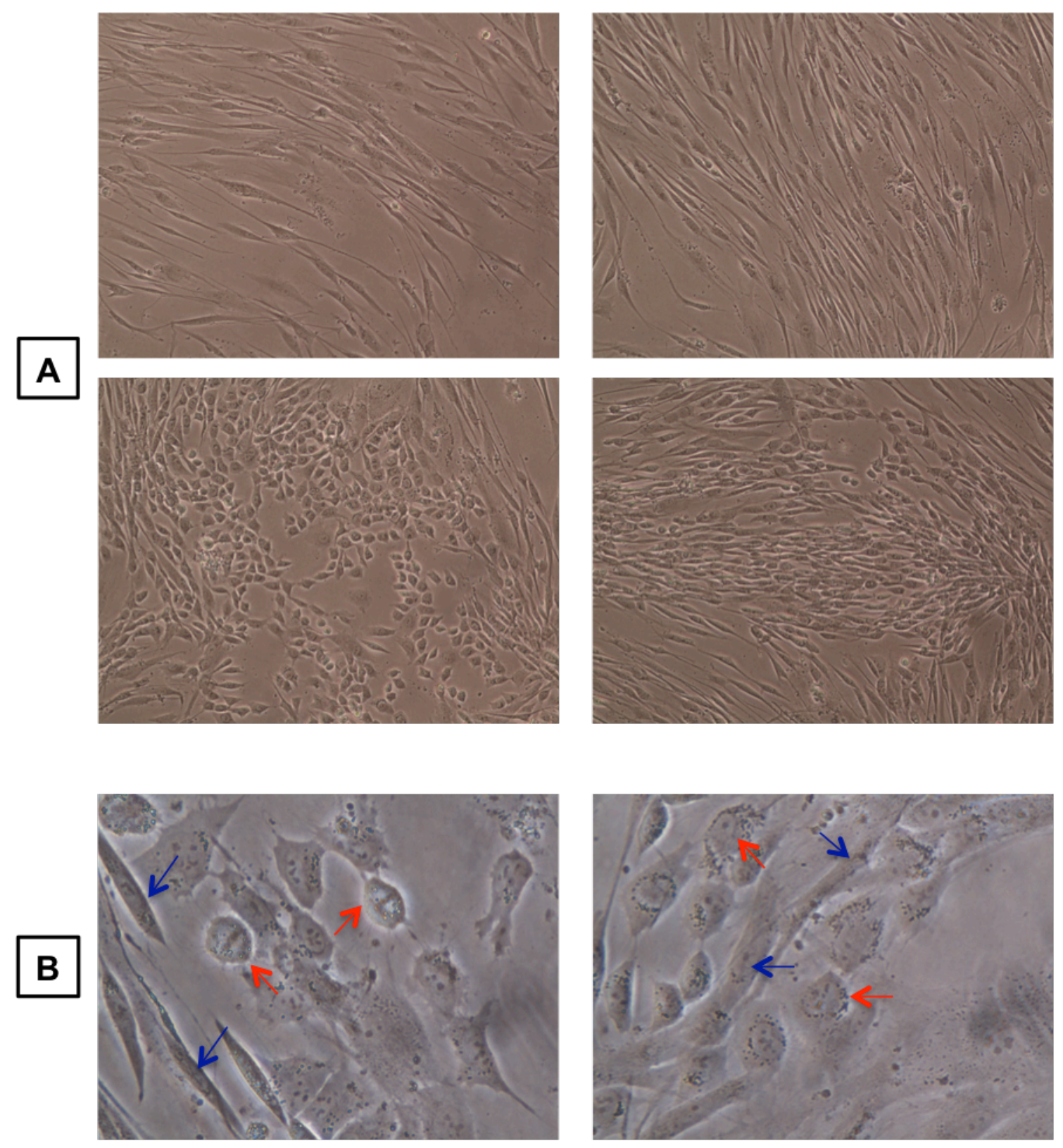

Figura 41. Microscopía de fibroblastos transdiferenciados a células $C D 45^{+}$. A. Imágenes tomadas con un aumento de 40X. Muestran como los fibroblastos van perdiendo su forma fusiforme y comienzan a redondearse y acortarse para formar células redondas, que son las células hematopoyéticas. B. Se observan las mismas células con un aumento de 100X. Las flechas azules indican los fibroblastos que aún permanecen como tal. Las flechas rojas indican los fibroblastos que se han transdiferenciado a células CD $45^{+}$. 
Una vez finalizado el experimento, 37 días después de haber transducido las células con el LV-Oct4, se despegan las células de la placa utilizando Colagenasa IV. Las células así obtenidas fueron, posteriormente, centrifugadas y lavadas antes de realizar la tinción con los anticuerpos correspondientes y la lectura en el citómetro de flujo.

Las células fueron divididas en 4 alícuotas, según se explica en detalle en el apartado 2.4.10 de la sección materiales y métodos. La primera de ellas, se utilizó como control negativo; la segunda fue teñida con un anticuerpo $\alpha$-CD45-PE-Cy7; la tercera fue sometida a tinción intracelular con un anticuerpo $\alpha$-WASP-APC; $y$, finalmente, la cuarta fue sometida a un doble marcaje con los anticuerpos $\alpha$-CD45-PE-Cy7 para tinción de membrana, en primer lugar, y $\alpha$-WASP-APC, para tinción intracelular, en segundo lugar.

En la figura 42 se pueden observar los análisis realizados en las muestras de FibsWASP+ transdiferenciados (Fibs-WASP+ T) y no transdiferenciados (Fibs-WASP+ NT). En la figura 42.A se observa una población correspondiente a las células hematopoyéticas $C D 45^{+}$que aparecen en los Fibs-WASP+ T, lo que no ocurre en los Fibs-WASP+ NT. La población que presenta el marcador CD45 en su superficie celular, corresponde con el $30 \%$ de las células que se han sometido al proceso de transdiferenciación. En consecuencia con este resultado, en la figura 42.B, se puede observar que la curva correspondiente a WASp se desplaza a la derecha, lo cual indica que, en las células transdiferenciadas existe una población capaz de producir la proteína. Sin embargo, las células capaces de producir WASp son prácticamente la mayoría de los Fibs-WASP+ T, lo cual puede ser explicado teniendo en cuenta que se ha descrito que la proteína comienza a producirse en estadíos previos a la expresión de CD45, en las células CD45 CD $31^{+}$(Muñoz et al., 2012). Los casos hasta aquí mencionados corresponden a la tinción realizada con uno solo de los anticuerpos, y que por tanto, detecta o CD45 o WASp, pero no ambos.

En la figura 42.C se observa la proteína WASp, con un resultado similar al obtenido en a figura $42 . B$, con la diferencia de que en este caso las células han sido sometidas a una doble tinción, utilizando un anticuerpo de tinción intracelular, $\alpha$-WASP-APC (FL6), y un anticuerpo de tinción membrana, $\alpha$-CD45-PE-Cy7 (FL5). Es importante mencionar que en estas células no aparece una población de CD45 ${ }^{+}$. Según hemos visto en experimentos previos, esto podría deberse a que al fijar y permeabilizar las células para tinción intracelular de WASp, el CD45 que se encuentra en la membrana de la célula podría perderse, o bien, el anticuerpo liberarse de la unión a CD45. Aun 
así, observando las figuras anteriores, es evidente la aparición de una población de células $C D 45^{+}$y de células que expresan WASp.
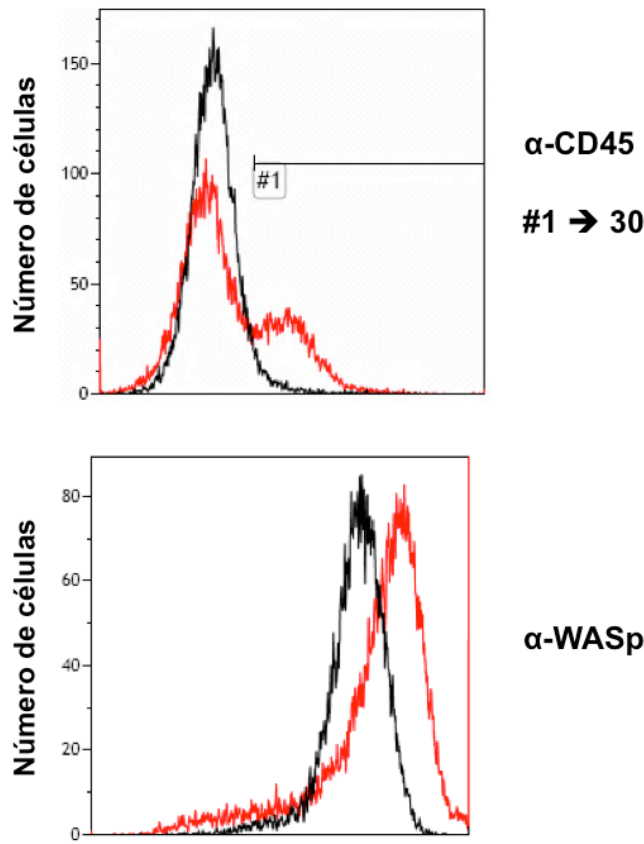

a-WASp

Fibs-WASP+ NT

Fibs-WASP+ T

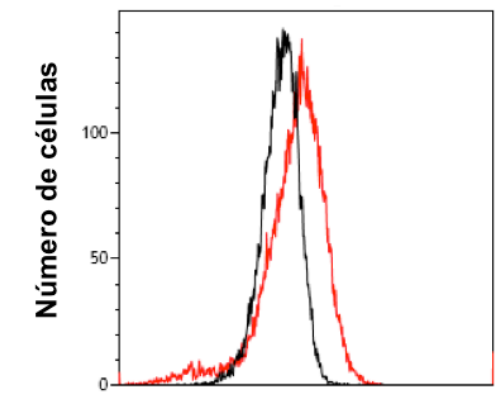

$\alpha-$ WASp

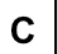

a-WASp

Figura 42. Análisis por citometría de flujo de los fibroblastos corregidos, transdiferenciados y no transdiferenciados. A. Análisis de CD45 en ambas poblaciones celulares, donde se observa la aparición de una población CD45 $5^{+}$en los fibroblastos transdiferenciados. B. Análisis de WASp, que aparece aumentado en los fibroblastos corregidos y transdiferenciados. C. Análisis de WASp en células sometidas a doble tinción para WASp y CD45. También aquí se evidencia el aumento de dicha proteína en los fibroblastos transdiferenciados.

Finalmente, con estas células corregidas y posteriormente transdiferenciadas (FibsWASP+T), realizamos un western blot (figura 43).

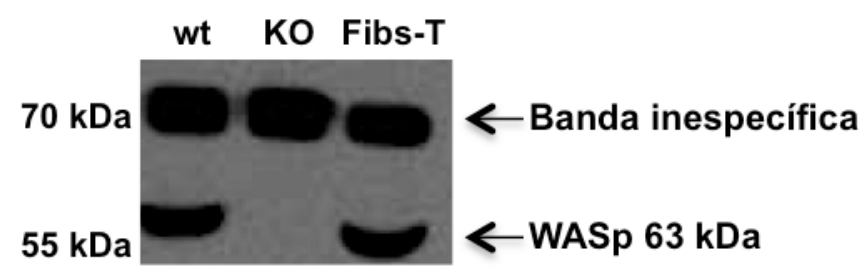

Figura 43. Western blot para evaluar la expresión de WASp en fibroblastos transdiferenciados a células hematopoyéticas. Se utilizan como control positivo, la línea Jurkat, y como control negativo, los fibroblastos KO. 
Con este western blot, comprobamos la expresión de la proteína WASp, usando como control la expresión en células Jurkat, que expresan la proteína en gran cantidad (control + ), en células y Jurkat KO que no la expresan (control-). Según se puede observar en la figura, las células corregidas son ahora capaces de expresar la proteína WASp, lo cual se correlaciona con los resultados obtenidos mediante citometría de flujo. 


\section{DISCUSIÓN.}

"Duda siempre de ti mismo, hasta que los datos no dejen lugar a dudas"

Louis Pasteur (1822 - 1895) 


\section{Línea celular reportera.}

Según lo explicado previamente, se obtuvo una línea celular reportera HCT116-RCL en la que comprobamos, en primer lugar, la inserción sitio específica del constructo, dentro del genoma de la célula diana; en segundo lugar, comprobamos mediante PCR, que la inserción del DNA exógeno que contiene la EGFP truncada en el extremo $3^{\prime}$ en la célula diana, se ha realizado sólo en uno de los dos alelos posibles; y, en tercer lugar, comprobamos que no existen células que expresen la proteína fluorescente verde en ausencia del rAAV, y que las células verdes que aparecen indican con seguridad que ha sucedido $\mathrm{RH}$.

Es importante mencionar que, cuando decidimos generar una línea celular reportera, nos propusimos introducir nuestro transgén en un locus conocido. Más en concreto, un locus de los llamados inocentes, es decir, aquel cuya modificación no se espera que produzca ninguna alteración funcional en la célula. Hoy en día se conoce que un locus seguro debe ser capaz de expresar de manera estable el transgén que se inserta, a la vez que es de vital importancia su seguridad en cuanto a que no debe interferir con el funcionamiento celular ni con la regulación génica (Silva et al., 2011). Actualmente se conocen, al menos, 3 loci que cumplen estas características y son: el sitio AAVS1 (sitio de integración 1 del virus adenoasociado) en el cromosoma 19; CCR5 (receptor de quimiocinas 5) en el cromosoma 3; y el ortólogo humano del locus de ratón ROSA26 también en el cromosoma 3. Si bien hasta el momento estos 3 loci parecen buenos candidatos para la introducción de un transgén, falta por conocer si son completamente seguros respecto, por ejemplo, a las consecuencias que pueda tener la integración de un DNA exógeno en este sitio sobre los genes vecinos. Nosotros hemos elegido el sitio AAVS1, fundamentalmente porque se ha comprobado previamente que la expresión de GFP en esta localización es óptima, mayor, por ejemplo, que cuando se inserta el mismo gen en el locus CCR5 (Sadelain et al., 2011). Recordemos que el sitio AAVS1, se encuentra en el intrón 1 del gen de la fosfatasa 1 subunidad regulatoria 12C (PPP1R12C, también conocida como MBS85), que codifica para una proteína sin función conocida hasta el momento y cuya ausencia, no es causante de patología (Henckaerts et al., 2010).

El uso de este sitio presentaba, además, la ventaja de que existe una nucleasa comercial de tipo ZFN capaz de introducir una rotura en la doble hebra del DNA. Esta nucleasa ZFN-AAVS1 se ha usado, simplemente, para facilitar la introducción de nuestro transgén en el sitio AAVS1 puesto que, como se ha comentado, se favorece así la $\mathrm{RH}$ en presencia de un DNA homólogo donante. 
La construcción de la línea reportera fue llevada a cabo en células humanas HCT116, las cuales tienen una mutación en el gen MLH1 que, como ya se mencionó anteriormente, favorece la reparación del DNA mediante $\mathrm{RH}$. Otras líneas reporteras han sido previamente descritas, como es el caso de la línea XR1. Esta línea fue generada en un mutante derivado de la línea celular $\mathrm{CHO}$ (línea celular de ovario de hámster chino), que no expresa XRCC4, proteína que interviene en el proceso de NHEJ. Así mismo, el genoma de esta línea celular contiene dos casetes inactivos del gen de resistencia a neomicina, de los cuales, el primero, incorpora un sitio de restricción para la enzima I-Scel, y el segundo para Ncol, y ambos están separados por otro casete de resistencia, en este caso a higromicina. Cuando ocurre $\mathrm{RH}$ entre la línea celular y un plásmido que codifica para la enzima I-Scel, se constituye un casete de resistencia a neomicina funcional, lo cual convierte a las células en resistentes frente a este antibiótico (Delacôte et al., 2002). Esta línea, presenta una desventaja a la hora de realizar estudios cuyos resultados deban ser posteriormente extrapolados a células humanas, puesto que es una línea murina, es así que la línea construida por nosotros parece una mejor opción. Por otro lado, ambas líneas comparten el hecho de contener una mutación en un gen que interviene en vías de recombinación no homóloga, lo cual es favorable para estudios de recombinación homóloga. Otra línea reportera descrita en la literatura es la línea DR-GFP, la cual está compuesta de dos genes EGFP mutados de manera diferente, y separados por un casete de resistencia a puromicina. En uno de los genes EGFP se introduce un sitio de restricción para la enzima I-Scel, mientras que en el otro se introduce un sitio para Bcgl, lo cual hace que ambos sean inactivos y no expresen la proteína fluorescente verde. Cuando el sitio de I-Scel es escindido por la acción de la endonucleasa (codificada por un plásmido), ocurre $\mathrm{RH}$ entre ambos genes recuperándose la expresión de la proteína fluorescente verde. Esta línea DR-GFP tiene la ventaja de haberse construido en células humanas, HeLa, pero tiene la desventaja de presentar una mutación en el gen XRCC3, el cual se ha visto que promueve la reparación de las DSBs mediante $\mathrm{RH}, \mathrm{y}$ que por lo tanto, ante su ausencia se vería favorecida la reparación mediante NHEJ. Otra desventaja que presenta esta línea celular, con respecto a nuestra línea reportera es que se observaron casos de aparición de células verdes, incluso en ausencia de transfección del plásmido que codifica para I-Scel, lo cual se atribuye a fenómenos de mutación espontánea que no fueron comprobados (Pierce et al., 1999). Este fenómeno no fue observado en nuestra línea celular, debido a que la secuencia de la EGFP se encuentra dividida en dos DNAs diferentes, por lo cual, la única manera de que se observen células verdes, es que ocurra $\mathrm{RH}$ entre las secuencia contenida en la HCT116-RCL (EGFP truncada en el extremo 3') y la secuencia del AAV- 55 -EGFP- 
donor (EGFP truncada en el extremo 5'). Así mismo, debemos recordar otra de las ventajas que posee nuestra línea con respecto a esta última y es la de ser deficiente en el gen MLH1, por lo que, la proteína codificada por este gen, que interviene en el sistema de reparación de desemparejamientos (mismatch repair system) no es expresada e, indirectamente, se favorece la $\mathrm{RH}$ como mecanismo de reparación en dichas células.

Cómo mencionamos anteriormente, para llevar a cabo la corrección de EGFP y obtener así una proteína funcional, se añadió el virus AAV- $\Delta 5$-EGFP-donor a la línea reportera. El hecho de utilizar este vector viral en lugar de un plásmido, es debido a que la eficiencia de recombinación entre un rAAV y el DNA diana es mayor que en el caso de un plásmido. Se conoce también que, para que ocurra modificación génica dirigida con rAAVs, este vector debe contar con, al menos, 150 bases en el extremo 5' y 500 bases $3^{\prime}$ que sean homólogas al sitio de inserción (Vasileva et al., 2005), lo cual se cumple en nuestro caso, ya que en el extremo $5^{\prime}$ tenemos unas 600 bases que encuentran su homología en el genoma de la línea celular reportera, mientras que en el extremo 3', el brazo completo (1.3 kb) es homólogo al sitio AAVS1. La modificación génica dirigida requiere de la vía de la $\mathrm{RH}$, mientras que la NHEJ no interviene en el proceso. Para que se lleve a cabo este mecanismo, es muy importante que el genoma del rAAV sea ssDNA. Se hipotetiza, que las ITRs del virus recombinante se asemejarían a roturas en el DNA, lo cual podría inducir respuestas de reparación del tipo de las que ocurren cuando existen situaciones de daños en el DNA. Para el inicio de la $\mathrm{RH}$ entre el rAAV y el gen a modificar, y tras la remoción de la cápside viral, RPA (proteína de replicación $A$ ) se une a la cadena de DNA sencilla del $\mathrm{rAAV}$, tras lo cual se recluta el complejo BRCA2-RAD51 que sustituye a RPA. Se cree que, luego, XRCC3 podría favorecer la formación del filamento nucleoproteico por parte de RAD51, en la cadena de DNA sencilla del rAAV. El filamento de RAD51 encuentra y se empareja con la secuencia homóloga complementaria en el genoma de la célula diana, en el locus a modificar. Esto requiere, además, que las helicasas RAD54L y RAD54B, interaccionen con RAD51 y desenrollen la doble hélice de DNA, tras lo cual se produce la modificación en una de las cadenas del DNA (Vasileva et al., 2005). Esta podría ser la explicación de cómo ocurre la recombinación entre nuestro virus adenoasociado recombinante y el genoma de la células reportera, y la explicación de por qué los rAAV son una muy buena opción a la hora de llevar a cabo diferentes protocolos de terapia génica.

Por otro lado, hemos obtenido el virus donante AAV- 45 -EGFP-donor, y hemos comprobado que cuando se transfecta en la línea celular parental de la que deriva la 
célula reportera, no aparecen células verdes; sólo se generan células verdes cuando el virus donante infecta la célula reportera. Además, se clonaron varias de las células verdes recombinantes obtenidas, se expandieron y se analizó mediante secuenciación el nuevo gen recombinante, comprobándose en todos los casos la secuencia, esperada sin mutaciones. Aparentemente, la expresión del transgén es constante, puesto que no se observó desaparición o disminución de la señal fluorescente después de numerosos pases de los clones, durante más de tres meses en cultivo. Ninguno de los clones presentó anormalidades morfológicas o alteraciones en la tasa de crecimiento, y el análisis del ciclo celular no mostró diferencias respecto a las HCT116 wild-type en la distribución de poblaciones en el ciclo.

También ensayamos en 12 clones diferentes la eficiencia de $\mathrm{RH}$ obtenida, comprobándose una variación significativa en cuanto a la frecuencia de $\mathrm{RH}$ entre clones distintos, lo que podría explicarse por un efecto clonal. Es decir, las células usadas para el experimento representan una población policlonal que, probablemente, da lugar a un ambiente genómico y proteómico diferente para cada una, y que hace que éstas respondan también de forma diferente en cuanto a la mayor o menor permisividad de $\mathrm{RH}$ para condiciones experimentales iguales.

A pesar de la utilidad comprobada de esta línea reportera, se obtenía un número de recombinantes relativamente bajo, lo cual representaba un problema para el cálculo de variaciones de eficiencia recombinatoria, cuando hacíamos los ensayos en placas de 96 pocillos (escaso número de células), utilizando muchas variables experimentales simultáneamente. Así que decidimos utilizar un método que incrementara el número de eventos recombinatorios; este método consistió en la adición de nucleasas específicas que introducían un DSB en el locus a modificar (Humbert et al., 2012); así nació la idea de construir una pareja de nucleasas TALENs.

Cabe recordar que las TALENs son proteínas de fusión, compuestas por un dominio modular de unión a DNA y por un dominio enzimático (Fokl), que realiza la escisión de la doble hebra. Habiendo diseñado las TALENs para que reconozcan y corten una secuencia muy próxima al gen EGFP mutado, fuimos capaces de inducir un importante incremento en la frecuencia de $\mathrm{RH}$ mediante la utilización del AAV- $\Delta 5$ EGFP-donor, como DNA donante. También observamos que las células mantienen su viabilidad normal, lo que nos permite pensar que la pareja de plásmidos que codifican para las TALENs no son tóxicas para las células tratadas.

Si bien se obtuvieron los resultados esperados, es decir, un importante aumento en la frecuencia de $\mathrm{RH}$, somos conscientes de la posibilidad de cortes en sitios fuera de la 
diana (off-target), por lo que, estas nucleasas se han utilizado sólo en los experimentos preliminares realizados en la línea reportera. Es decir, su finalidad no fue otra que la de permitirnos aumentar el número de células verdes recombinantes, y con ello facilitarnos el contaje de las mismas. Sin embargo, idealmente se pretende aplicar los reactivos más eficaces conocidos, pero sin el uso de las nucleasas, de forma que pudiera obtenerse de manera más segura un aumento suficiente de $\mathrm{RH}$ que permita la futura traslación clínica de los nuevos métodos.

\section{Cambios en la frecuencia de recombinación homóloga.}

Como hemos mencionado al finalizar el apartado anterior, los ensayos llevados a cabo en la línea reportera tienen como objetivo final el hallazgo de diversos reactivos que por sí mismos o en combinación, sean capaces de incrementar la frecuencia de RH de manera significativa.

Es sabido que la proteína humana Rad52 (hRad52) existe en una conformación heptamérica, que se une a una cadena sencilla de DNA promoviendo así la hibridación de ésta con su hebra complementaria, y estimulando la $\mathrm{RH}$ mediada por Rad51 (Sugiyama et al., 1998). Algo similar ocurre con ScRad52, el gen de levaduras Saccharomyces cerevisiae ortólogo de RAD52 humana, donde se ha visto que cuando la proteína está ausente, estas levaduras acumulan mutaciones, a la vez que muestran una incrementada sensibilidad a los agentes que dañan el DNA, debido a su importante rol durante el proceso de RH (Lok et al., 2012). A pesar de que, tanto la proteína humana como la de la levadura, comparten propiedades físico-químicas similares y la afinidad preferente por las cadenas de DNA sencilla, su capacidad para inducir $\mathrm{RH}$, no es la misma. Esto podría deberse a las diferencias estructurales que existen entre hRad52 y ScRad52, ya que la proteína humana contiene 418 aminoácidos, frente a los 471 de la levadura, encontrándose que 33 aminoácidos que aparecen en el extremo N-terminal de la proteína de la levadura, no están presentes en la proteína humana, además de que entre los aminoácidos 34 y 198 sólo hay un $46 \%$ de homología; mientras que en el extremo C-terminal de ambas moléculas hay poca o ninguna homología. Así mismo, ScRad52 posee una mayor afinidad por las hebras de DNA simple que la proteína humana y, por ende, es más eficiente a la hora de promover el intercambio de cadenas durante el proceso de RH (Kalvala et al., 2010). Todas estas diferencias entre ambas nos llevaron a seleccionar ScRad52 para nuestros ensayos. Por ello, hemos construido un vector de expresión en bacterias para la producción de la proteína recombinante, con objeto de aplicarlo en los 
experimentos de recombinación homóloga en la línea celular reportera HCT116-RCL. Así, hemos podido comprobar que la proteína de fusión fue construida de manera correcta, ya que la misma penetra no sólo la membrana celular, sino también la membrana nuclear, llegando así al núcleo donde es capaz de cumplir su función correctamente.

Cuando la proteína ScRad52 se utilizó para tratar la línea reportera, en presencia de nucleasas quiméricas TALENs y rAAV se ha conseguido aumentar la frecuencia de $\mathrm{RH}$ más de lo que se incrementó con el sólo uso de nucleasas y rAAV. Este resultado no sólo es indicativo de la correcta funcionalidad de la proteína obtenida, sino que además, confirma la capacidad de la proteína de $S$. cerevisiae de provocar un aumento de la frecuencia de RH también en células humanas.

El incremento en la frecuencia de recombinación homóloga inducido por ScRad52, junto con la reducción de la NHEJ del DNA, se corresponde con la idea de que ambas vías de reparación son alternativas y competitivas entre sí. A su vez, ScRad52 también parece unirse a Ku, un complejo implicado en la unión temprana a roturas del DNA y que inicia la vía de NHEJ, explicando así la disminución de las inserciones al azar (Di Primio et al., 2005).

Ensayamos, también, otras alternativas experimentales con nuestra línea reportera, como es el caso del compuesto químico denominado RS-1 ((3-[(benzylamino)sulfonyl]4-bromo-N-(4 bromophenyl)benzamide) del que se ha publicado que induce un cambio alostérico en el filamento de RAD51 y aumenta la RH en fibroblastos humanos sin afectar la viabilidad celular (Jayathilaka et al., 2008). Nosotros hemos realizado diversos ensayos con este químico en la línea celular reportera HCT116-RCL utilizando diferentes condiciones, entre ellas, la que se describe en el ensayo realizado por Jayathilaka et al. Sin embargo, en todos los casos hemos obtenido una elevada mortalidad celular, a todas las concentraciones ensayadas, lo que podría explicarse por una excesiva sensibilidad a dicho químico de nuestra célula reportera en comparación con los fibroblastos, que son las células que se usaron en dicha publicación con lo cual no somos capaces de concluir sobre su efecto en la frecuencia de $\mathrm{RH}$.

Además de la proteína de fusión y el químico ya comentados, también decidimos explorar cómo la deficiente expresión de ciertas proteínas podría afectar a la $\mathrm{RH}$; para lo cual se utilizaron diferentes RNAs pequeños de interferencia (siRNA). Es así que se diseñó una librería de 84 siRNAs cuyos genes dianas codifican proteínas que en su mayoría están implicadas directamente en el proceso de NHEJ, y otras de función 
poco conocida que, indirectamente, parecen afectar dicho proceso. Nuestro objetivo, ha sido utilizar herramientas que eviten en lo posible la corrección génica que pueda introducir errores en el genoma, lo cual se conseguiría favoreciendo las vías implicadas en $\mathrm{RH}$, así como inhibiendo las que participan en NHEJ (Moynahan et al., 2010).

A pesar de que la librería incluye siRNAs para los que se ha descrito, en mayor o menos medida, cierto efecto en el proceso de reparación génica, solamente en 12 de ellos hemos podido constatar un aumento de la frecuencia de $\mathrm{RH}$ en nuestra línea celular reportera.

Uno de estos, está dirigido contra XRCC6, un gen que codifica para la proteína Ku70, que funciona formando un heterodímero con Ku80. Este complejo, actúa durante el proceso de NHEJ bloqueando los extremos que se producen durante un DSB, y manteniéndolos muy próximos entre sí, lo cual evita que ocurra la resección de los extremos 5', proceso necesario para la activación de la vía RH (Chapman et al., 2012). Es así que, la disminución inducida en la expresión de Ku previene el inicio de NHEJ y, determinaría que la reparación ocurra sobre todo mediante $\mathrm{RH}$. Hay que decir, que para cada uno de los 12 siRNAs potenciadores de $\mathrm{RH}$, hemos realizado también ensayos de ciclo celular en paralelo. Está descrito (Langerak et al., 2011) que los fenómenos de RH y NHEJ no ocurren con la misma frecuencia en todas las fases del ciclo celular, lo que se explica sobre todo por la diferente expresión de las distintas proteínas implicadas en uno u otro proceso en las distintas fases. NHEJ ocurre sobre todo en G0, G1 y S temprana, mientras que RH predomina en la fase S tardía y G2 del ciclo celular. El tratamiento con siRNA para Ku, produce un aumento del porcentaje de células en fase $S$ respecto al control no tratado, lo que podría explicar en parte, el aumento observado en la frecuencia de RH. Este efecto sobre el ciclo celular del siRNA-Ku no produce incremento de mortalidad celular y es transitorio, ya que los niveles del siRNA transfectado disminuyen naturalmente en pocos días. Por lo tanto, debería considerarse la posibilidad de incluir este o cualquier otro siRNA con similar efecto, en los protocolos de modificación génica dirigida para aumentar la probabilidad de éxito, por aumento de la frecuencia de $\mathrm{RH}$, sin aumento significativo de la mortalidad celular.

El uso de un siRNA contra XRCC6BP1 (proteína de unión a XRCC6, también llamada KUB3) es otro de los que da lugar a un aumento de la frecuencia de $\mathrm{RH}$. La unión de XRCC6BP1 a Ku70 sugiere una intervención de esta proteína en la vía de la NHEJ (Yang et al., 1999), probablemente debido a que cumple su función en la regulación de dicha vía (Fischer et al., 2013). Se ha visto la amplificación y sobrexpresión de este 
gen en glioblastomas, lo que está directamente relacionado con la capacidad de estas células de presentar resistencia frente a ciertos tipos de fármacos que inducen DSBs en el DNA de las mismas (Fischer et al., 2007). Lo hasta aquí expuesto podría ser la causa de que al utilizar este siRNA, y disminuir por tanto la expresión de este gen, se produzca una disminución en la vía de la recombinación no homóloga e indirectamente, se favorezca la reparación de las rupturas generadas por las TALENs haciendo uso de la vía de la $\mathrm{RH}$. Al realizar el análisis del ciclo celular en las células con el gen XRCC6BP1 silenciado, no se encontraron variaciones con respecto al control, ni en cuanto a la distribución de las células en las diferentes fases del ciclo, ni en cuanto a la viabilidad celular, lo cual hace de este siRNA una molécula capaz de ser utilizada con eficiencia en ensayos de modificación génica dirigida. Es importante destacar que, hasta donde sabemos, no hay ninguna publicación que describa el efecto de esta proteína sobre la frecuencia de $\mathrm{RH}$ y suponemos que su acción es indirecta, a través de Ku70.

Otro de los siRNAs que causan aumento de la frecuencia de $\mathrm{RH}$ es el que está dirigido contra el gen SFR1 (Swi five-dependet recombination repair protein 1). Sfr1 interacciona con la proteína Swi5 en una relación estequiométrica 1:1, interacción sujeta a la formación del complejo por ambas proteínas, ya que ninguna de las dos por separado son capaces de producir el efecto funcional del complejo, que consiste en estabilizar el filamento nucleoproteico formado por Rad51, con lo cual se estimula el intercambio de cadenas mediado por Rad51 (Tsai et al., 2012). De acuerdo a lo dicho, cabría esperar que al utilizar un siRNA frente a este gen, hubiésemos obtenido una frecuencia de $\mathrm{RH}$ disminuida cuando, por el contrario, se ha obtenido el efecto opuesto, un aumento en dicha frecuencia. Se conoce que existen otras proteínas, como Rad54, o complejos de proteínas, como Hop2-Mnd1, que puedan suplir la función del complejo Swi5-Sfr1. Según esto, hipotetizamos que la formación del complejo Swi5-Sfr1, podría actuar regulando de alguna manera la actividad de estas proteínas mencionadas, es decir, en caso de haber una disminución de SFR1 o Swi5 e indirectamente del complejo, estas otras proteínas o complejos de proteínas podrían, ya sea por sobrexpresión o bien, por cumplir una función antes llevada a cabo por Swi5-Sfr1, tener un efecto cuya consecuencia sea el aumento en la frecuencia de RH. Así mismo, se ha demostrado que células KO para el gen SFR1 proliferan con la misma cinética, y presentan la misma distribución en el ciclo celular que las células wild-type, lo cual indica que esta proteína no es esencial en la proliferación ni en la viabilidad celular (Akamatsu et al., 2010) y, de manera indirecta, estaría indicando que tampoco es esencial para la $\mathrm{RH}$, ya que se conoce que la ausencia total de $\mathrm{RH}$ es 
causa indirecta de inestabilidad genómica que pueden acabar en detención del ciclo celular e incluso en la muerte de las células (McCabe et al., 2006). Sin embargo, nosotros observamos que nuestras células proliferan normalmente, que son capaces de formar clonas y mantenerlas en el tiempo, a la vez que no se ve afectada la viabilidad celular. Tampoco hemos observado variaciones en la distribución celular a lo largo de las diferentes fases del ciclo celular, comparada con el control sin tratar, con lo cual, este siRNA podría utilizarse, sin mayores inconvenientes, en ensayos de modificación génica dirigida.

Por otro lado, comprobamos que el siRNA dirigido contra el gen CNGA1, también es capaz de generar un incremento en la frecuencia de $\mathrm{RH}$. La proteína codificada por este gen está involucrada en la foto-transducción de señales en la retina del ojo, es decir que, esta proteína interviene en el proceso por el cual la luz se convierte en señales eléctricas (Nache et al., 2006). Si bien no conocemos de qué manera puede estar involucrado este gen en las vías de reparación del DNA, creemos que de alguna manera podría intervenir en el ciclo celular ya que según hemos visto en experimentos de citometría de flujo, la mayor parte de las células transfectadas con este siRNA se encuentran en la fase $S$ del ciclo celular, lo cual no ocurre en la población utilizada como control, y tampoco se evidencia una mortalidad celular significativa. El elevado porcentaje de células en fase $S$ podrían explicar, al menos parcialmente, el porqué del incremento en la $\mathrm{RH}$.

Otro siRNA que produce un aumento en la frecuencia de recombinación homóloga, es el dirigido contra el gen CREBBP (proteína de unión a CREB, o también CBP, del inglés, CREB binding protein), una acetiltransferasa de histonas que se expresa de forma ubicua y está implicada en la coactivación transcripcional de muchos factores de transcripción diferentes. La acetilación de histonas tiene por función neutralizar las cargas positivas de dichas proteínas con lo cual se reduce la capacidad de estas para unirse al DNA, lo que lleva a la relajación de la cromatina, y facilita el reclutamiento de factores de transcripción y de la maquinaria de transcripción a secuencias específicas de DNA (Valor et al., 2013). Tanto CREBBP como p300, otra proteína acetiltransferasa, tienen la capacidad de acetilar y regular la actividad de varios factores de transcripción entre los que se encuentran p53, E2F, NF-кB y c-Myc. La acetilación, en estos casos, afecta tanto la capacidad de estos factores de unirse al DNA, como también, la capacidad de reclutar otras proteínas (Turnell et al., 2006). Por ejemplo, CREBBP y p300 funcionan como co-activadores para la proteína supresora de tumor p53, lo que sugiere una actividad indirecta en la supresión de tumores. Por otro lado, se ha visto que la reducción en la expresión de CREBBP en células 
quiescentes tiene por resultado la inducción de c-myc y la entrada en fase $\mathrm{S}$ del ciclo celular, a la vez que también se observó que una disminución en la expresión de p21 y una hiperfosforilación de p107 y 130 (los tres, reguladores negativos del ciclo celular), lo que podría también contribuir en la entrada a la fase $S$ del ciclo celular (Rajabi et al., 2005). Según los resultados que hemos obtenido mediante el silenciamiento génico de CREBBP, hipotetizamos que el incremento en la frecuencia de $\mathrm{RH}$ podría estar relacionado con las dianas de CREBBP. Es decir, sería una causa indirecta de la disminución de CREBBP que podría deberse, como se mencionó anteriormente, tanto a la regulación a la alta por parte de $c-m y c$, como a la disminución de los reguladores negativos del ciclo celular, dando como resultado un mayor número de células en fase $S$ del ciclo celular, y por tanto, una mayor capacidad para recombinar de manera homóloga. Este aumento del número de células en la fase $\mathrm{S}$ del ciclo celular ha sido comprobado por nosotros en los ensayos de ciclo celular, donde se obtuvo la mayoría de las células en dicha fase, Sin embargo, si bien hasta aquí es un buen resultado en cuanto a la obtención de un número mayor de células recombinantes, con respecto al control, se conoce que cuando CREBBP no es capaz de llevar a cabo su función, aumenta el riesgo de aparición de células tumorales, lo cual podría deberse tanto a un crecimiento celular desmedido, debido a la regulación a la alta de c-myc, como también a la inhibición de la función supresora de tumor por parte de p53 (Karamouzis et al., 2007).

Otro de los siRNAs que utilizamos y con el que hemos logrado aumentar la frecuencia de $\mathrm{RH}$, es aquel dirigido contra TAF4 (factor asociado a la proteína de unión a TATA, 4 del inglés, TBP (TATA binding protein) association factor 4). TAF4 actúa en diferentes vías de señalización, como un importante coactivador que interactúa con CREBBP o con p300 para potenciar la función de CREB, observándose que la ausencia de TAF4 disminuye drásticamente la actividad transcripcional de CREB (Davidson et al., 2005). Es probable, que esta interacción pueda ser la explicación de por qué del aumento en la frecuencia de recombinación homóloga, tal como hemos explicado para el siRNA previo. Sin embargo, el aumento que hemos obtenido, silenciando este gen ha sido inferior al obtenido con el silenciamiento de CREBBP, por lo cual creemos que, o bien el silenciamiento por parte de TAF4 es tal que, aún existe proteína capaz de interactuar con CREBBP o p300; o bien, que al ser un efecto todavía más indirecto que el causado por CREBBP, este efecto sea menor a la hora, por ejemplo, de inducir la entrada de las células en fase $S$ del ciclo celular. Si hablamos del ciclo celular, hemos de decir que se ha comprobado que, en ratones deficientes en TAF4 se reducen las células en G1 y aumentan las células en S y G2 (Bahat et al., 2013), 
mientras que nosotros hemos visto que el mayor aumento en el ciclo celular se da en la fase G2, lo cual podría explicar de otra manera el aumento de la frecuencia de $\mathrm{RH}$, pero también la diferencia encontrada en cuanto al incremento en la frecuencia de $\mathrm{RH}$ causado debido al silenciamiento de este gen, comparado con el silenciamiento de CREBBP.

Otro de los siRNAs con que hemos conseguido aumentar la frecuencia de $\mathrm{RH}$ es el siRNA contra DNAJB4, también llamado HLJ1. Este es un gen que codifica para una proteína que pertenece a la, altamente conservada, familia de las proteínas chaperonas DNAJ/HSP40 (Borges et al., 2005). Las HSPs son de considerable interés ya que se han demostrado que juegan un importante rol en la progresión del ciclo celular y la muerte celular por apoptosis, lo cual hace que las chaperonas estén involucradas en diferentes procesos patológicos (Khalil et al., 2011). Es así que DNAJB4 actúa como un supresor tumoral, inhibiendo la progresión celular descontrolada, y por tanto, el crecimiento tumoral, lo que se cree que es debido a la activación de p21, que regula el avance de la fase $S$ del ciclo celular (Sterrenberg et al., 2011). Sin embargo, no está del todo claro de qué manera es que esta proteína interviene en la progresión del ciclo celular, ni de qué manera podría interactuar con otras moléculas que formen parte de la vía de la $\mathrm{RH}$ o de la NHEJ, por lo cual no somos capaces de encontrar, por el momento, un vínculo entre el silenciamiento génico de DNAJB4 y el incremento en la frecuencia de $\mathrm{RH}$, si bien sí que hemos observado que, al analizar el ciclo celular, la mayor parte de las células se encuentran en la fase $S$. También observamos que no hay cambios notorios en la viabilidad celular.

Otro siRNA que hemos ensayado, tiene la función de silenciar el gen de la Lig4 o LIGIV. La proteína codificada por este, es una ligasa de DNA esencial en el proceso de recombinación $V(D) J$ y en la reparación de los DSBs a través de la vía de recombinación NHEJ, en la que interactúa directamente con XRCC4 y Ku, e indirectamente con la proteína quinasa dependiente de DNA (DNA-PK) y el complejo MRN (De loannes et al., 2012). El complejo conformado por la DNA ligasa IV es absolutamente necesario para que se complete la reparación por la vía no homóloga (NHEJ) ya que, aunque existen otras DNA ligasas que comparten un alto grado de similitud, sólo esta posee la habilidad de llevar a cabo la reparación de las rupturas en el DNA (Kurosawa et al., 2013). A su vez, nosotros hemos comprobado que la mayoría de las células que interviene en este ensayo, se encuentran en la fase $S$ del ciclo celular, con lo cual podemos hipotetizar que debido tanto a la inhibición de los mecanismos de reparación NHEJ, como al aumento de células en fase $\mathrm{S}$ sin que se 
altere su mortalidad, es que el silenciamiento por parte de este siRNA es capaz de aumentar la frecuencia de $\mathrm{RH}$, y es a la vez, un buen candidato para ser usado en otros ensayos de modificación génica dirigida.

Por otro lado, el silenciamiento del gen SMCHD1, que codifica para una proteína miembro de la familia de proteínas SMC, encargadas del mantenimiento estructural de los cromosomas, y que intervienen en las funciones de condensación de la cromatina, segregación y reparación de DNA (Gendrel et al., 2013) también es capaz de causar un aumento en la frecuencia de $\mathrm{RH}$. Se ha visto que SMCHD1 puede intervenir tanto en la vía de la NHEJ, como en la $\mathrm{RH}$, lo cual se debe a que, en principio, la proteína colocaliza con Ku80 (NHEJ) en las primeras fases de la reparación del DNA, pero puede persistir en el sitio de daño por muchas horas y colocalizar con Rad51 (RH), encontrándose además que su disminución o ausencia es causa de DSBs sin resolver y, por tanto, de disminución de viabilidad celular (Coker at al., 2014). Contrariamente, también se ha visto que la disminución de SMCHD1 tiene como resultado una NHEJ mucho menos eficiente de lo que normalmente es, a la vez que esto produce la elevación de la frecuencia de reparación mediante RH (Tang et al., 2014). Frente a estas posturas opuestas, nosotros pudimos obtener un aumento en la frecuencia de $\mathrm{RH}$ con los dos siRNAs utilizados para silenciar este gen, y sin que la viabilidad celular se haya visto afectada, por lo cual concordamos con la segunda de estas posturas. Además de que también hemos visto un ligero aumento de las células en fase $S$ del ciclo celular.

Otro de los siRNAs capaz de producir un incremento en la frecuencia de $\mathrm{RH}$ ha sido aquel dirigido contra el gen WRB, el cual codifica para una proteína nuclear básica rica en triptófano (Vilardi et al., 2011). Si bien en este caso no hemos sido capaces de encontrar la relación entre el silenciamiento génico por parte de los dos siRNAs utilizados y el aumento de la frecuencia de $\mathrm{RH}$ obtenida, se ha descrito (Adamson et al., 2012. Słabicki et al., 2010) que aumenta considerablemente la frecuencia de RH sin modificar la viabilidad, lo que está de acuerdo con nuestros datos. También hemos observado un importante aumento de células en fase $S$ del ciclo celular, lo cual podría ser la explicación del aumento en $\mathrm{RH}$.

Por otro lado, MLH1 es un gen que codifica para una proteína que interviene en el sistema de reparación de desemparejamientos (mismatch repair system) del DNA, y en otros procesos celulares que van desde la regulación de los puntos de control (checkpoint) en el ciclo celular, la apoptosis, la recombinación meiótica, y hasta la organización del citoesqueleto (Hinrichsen et al., 2014); y cuyo siRNA hemos elegido para utilizar como control negativo, ya que sabemos que la línea HCT116 contiene una 
mutación en dicho gen. Sin embargo, este siRNA fue capaz de darnos un aumento en la frecuencia de $\mathrm{RH}$, que no esperábamos, pero que comprobamos utilizando 2 siRNAs dirigidos contra diferentes partes de la secuencia del gen. A pesar de que sabemos que existe una mutación homocigota en MHL1, no sabemos si podría existir un mínimo de expresión por parte de la proteína, o si bien, podría producirse una proteína truncada que conserve en parte la función y que, de esta manera, los siRNAs que hemos utilizado sean capaces de producir un silenciamiento génico sobre la misma. Por otro lado, hemos comparado las secuencias de reconocimiento de los dos siRNAs y hemos sido capaces de encontrar diferentes secuencias en el genoma, capaces de ser reconocidas por estos siRNAs. Sin embargo, ninguna de ellas estaría directamente implicada en el aumento de las frecuencia de $\mathrm{RH}$, aunque bien sabemos que no de todas se conocen todas las funciones y las relaciones que podrían tener, y que podrían, finalmente, producir un aumento en $\mathrm{RH}$. Es importante tener en cuenta aquí, la presencia de otro importante gen involucrado en la vía de reparación de desemparejamientos, $\mathrm{MSH}$, cuyos niveles no se ven alterados por la presencia o ausencia de MLH1, y que se cree que es el que realmente interviene en el proceso de apoptosis (Hawn wt al., 10095), ya que ha visto que mutaciones en el gen MLH1 no afectan la viabilidad celular. Todo esto podría explicar por qué las células reporteras transfectadas con los siRNAs proliferan de manera normal, su distribución del ciclo celular es la misma que el control, y por qué la viabilidad se asemeja, también a la del control. Nosotros también hemos utilizado un siRNA contra el gen MSH2, con el cual, sin embargo, no hemos obtenido el aumento esperado en la frecuencia de recombinación homóloga.

Finalmente, el siRNA dirigido contra RPS6KA5 (proteína quinasa S6 ribosomal alfa 1, del inglés, ribosomal protein S6 kinase alpha-5), también conocida como MSK1 (proteína quinasa 1 activada por estrés y mitógenos, del inglés, mitogen- and stressactivated protein kinase 1), también generó un aumento en la frecuencia de $\mathrm{RH}$. RPS6KA5 es una proteína que, junto con la isoforma MSK2, son activadas mediante las cascadas de señalización de las quinasas ERK1/2 y p38 MAPK (Deak et al., 1998). Además, se ha visto que MSK1 y MSK2 son necesarias para la fosforilación de diferentes factores de transcripción como CREB y ATF1, y también para la fosforilación de la histona $\mathrm{H} 3$, lo cual al igual que en el caso de CREBBP nos habla de una activación de la transcripción (McCoy et al., 2005). Debido a esto, creemos que aquí al estar ausente RPS6KA5 podría estar sucediendo algo similar que con la ausencia de CREBBP, con lo cual podría esperarse un aumento del número de células en fase S, por activación de c-myc, con lo cual se favorecería de manera indirecta, el 
aumento de la frecuencia de $\mathrm{RH}$. Sin embargo, nosotros hemos observado que en el silenciamiento producido por este siRNA no tiene influencia en el número de células que se encuentran en las diferentes fases del ciclo celular, como tampoco se observan alteraciones en la viabilidad celular.

Cabe recordar que, para todos los genes mencionados anteriormente se han utilizado, al menos dos siRNAs diferentes, dirigidos contra secuencias distintas del mismo gen, a la vez que se han intentado utilizar siempre siRNAs validados, es decir, que se conoce el porcentaje de silenciamiento que causa el siRNA. También hemos de recordar que para la mayoría de los ensayos se han utilizado siRNAs de última generación, denominados silencer select siRNAs, los cuales contienen modificaciones químicas, que les confieren ciertas ventajas en estabilidad y especificidad, ya que se utilizan en dosis hasta 10 veces menores, con respecto a los siRNAs normales.

Cómo se mencionó anteriormente, para todos estos siRNAs se ha realizado un estudio del ciclo celular; y, si bien hemos obtenido diferentes resultados en cuanto a la distribución de las poblaciones celulares en las diferentes fases del ciclo, no somos capaces de decir con certeza si, una vez eliminado el efecto del siRNA las células continúan ciclando con normalidad. Sin embargo, podemos inferir que esto es así, ya que según hemos visto en los diferentes experimentos realizados, las células recombinantes siguen dividiéndose, lo cual ha quedado de manifiesto en las observaciones realizadas a lo largo de una semana después observar las primeras células recombinantes, donde podemos ver que las células individuales, observadas al principio, son capaces de formar clones con múltiples células.

Existen diversos métodos que pueden detener las células en una fase determinada del ciclo celuar. Por ejemplo, entre los métodos más comunes para sincronizar células, particularmente en la fase $S$ del ciclo, se encuentran los inhibidores de la replicación del DNA, como ser hidroxiurea, metrotrexato, afidicolina o timidina. La ventaja de la sincronización celular mediante estos agentes, es la facilidad de uso y su bajo coste. Sin embargo, estos métodos podrían presentar algunos inconvenientes ya que se genera un crecimiento desbalanceado debido a que, durante la detención en la fase $S$ la síntesis de RNA y de proteínas, junto con el agrandamiento celular continúan, mientras que la síntesis del DNA no lo hace. Todo esto podría tener algún tipo de efecto sobre el normal funcionamiento de las células una vez que estas sean liberadas del bloqueo (Darzynkiewicz et al., 2011). En cuanto al bloqueo que se produce mediante la utilización de siRNAs, quizás debido al hecho de utilizar cantidades tan bajas de siRNA o al hecho de que su efecto es transitorio, no hemos observado que 
las células se hayan visto mayormente afectadas, cuando se las compara con controles sin tratar.

\section{Generación y corrección de líneas celulares WASP-KO.}

Como mencionamos anteriormente, el síndrome de Wiskott-Aldrich (WAS) es una inmunodeficiencia primaria severa ligada al cromosoma $X$, que se presenta en 1-10 de cada $10^{6}$ niños recién nacidos (Bosticardo et al., 2009). Debido a su baja prevalencia nos encontramos con la dificultad de obtener células mutadas en el gen WAS, directamente de pacientes que sufren la enfermedad, lo que nos llevó a tomar la decisión de generar una línea celular que no expresara la proteína WASp. Para ello decidimos utilizar fibroblastos humanos. Las razones de esta elección tuvieron que ver con la facilidad de conseguir estas células primarias y, también tuvimos en cuenta que, una vez corregida la mutación, podrían transdiferenciarse a células progenitoras hematopoyéticas, lo que nos daría la posibilidad de obtener posteriormente diferentes líneas hematopoyéticas diferenciadas, ya que es bien conocido que la proteína WASP se expresa sólo en esta clases de células (Blundell et al., 2010).

Para llevar a cabo la construcción y corrección de dichos fibroblastos primarios, utilizamos virus adenoasociados recombinantes $y$, para poder aumentar la frecuencia de $\mathrm{RH}$ del virus recombinante, decidimos usar, además, una de las estrategias que habíamos probado y que nos habían dado mejores resultados como potenciadores de $\mathrm{RH}$. En concreto, utilizamos siRNAs de manera individual o combinando varios de ellos. Con ello, podríamos comprobar, además, que los resultados obtenidos en la línea reportera se reproducían en una línea de células primarias. Así, hemos sido capaces de obtener células portadoras de una mutación en el exón 4 del gen WAS cuando utilizamos siRNAs tanto contra CREBBP, como CREBBP+SFR1, pero no cuando usamos el siRNA control negativo. Sin embargo, y según nuestra experiencia, este último dato no implica la ausencia de células $\mathrm{KO}$ si no que, probablemente, el hecho de no hallar clones positivos para la mutación se deba a que la cantidad de pocillos analizados no fue suficiente.

Una vez obtenida la línea celular WASP-KO en fibroblastos, ésta fue tratada con CRE recombinasa para eliminar el casete de blasticidina que hemos introducido como marcador de selección. Dicho casete estaba flanqueado por dos sitios loxP, los cuales representan los sitios de reconocimiento por parte de Cre recombinasa, y que son utilizados para eliminar el segmento génico situado entre ambos (Loonstra et al., 2001). En cultivos celulares, la recombinación mediada por Cre recombinasa se 
encuentra limitada por la toxicidad de la proteína y por la eficiencia de la transfección, siendo este último el principal factor limitante del uso del sistema Cre/loxP. Esta limitación ha sido drásticamente reducida mediante la adición de las secuencias TAT, que facilitan el paso de la proteína a través de la membrana plasmática y, NLS, que favorece la translocación al interior del núcleo celular donde la proteína será capaz de ejercer su función (Peitz et al., 2002). Según lo expuesto anteriormente, se concluye que hemos construido una proteína funcionalmente activa, que es capaz de atravesar en primera instancia la membrana plasmática, y posteriormente, la membrana nuclear donde, luego, es capaz de cumplir su función de escindir el casete de blasticidina. Hemos comprobado también, la alta eficacia con la que la proteína Cre es capaz de eliminar el segmento génico flanqueado por los sitios loxP.

Una vez obtenidos los fibroblastos WASP-KO, sin casete de blasticidina, decidimos repetir una vez más el mismo método para la corrección génica del gen previamente mutado; y de nuevo fuimos capaces de revertir la mutación introducida previamente, y obtener fibroblastos en cuyo genoma se encuentra una copia normal, wild-type, del gen WAS.

Durante el desarrollo de todo este trabajo fuimos introduciendo en el laboratorio nuevas herramientas que había sido recientemente descritas, como es el caso del sistema CRISPR/Cas9. Debido a que estas son de más fácil construcción que las TALENs y, a su elevada eficiencia de corte, decidimos utilizarlas en la construcción de otra línea celular WASP-KO, esta vez en una línea celular humana de linfocitos T (Jurkat). Utilizamos en este caso, una variante de las CRISPR clásicas que posee una mutación en Cas9 y que recibe el nombre de Cas9 nickasa.

Se construyó, entonces, una pareja de nickasas CRISPRs para que generen un corte en la doble hebra de DNA, en las cadenas opuestas del gen diana (Harrison et al., 2014). Esta pareja de nickasas, encuentran su secuencia diana en el gen que codifica para WASp, más precisamente en el intrón 6, y que se corresponde con el extremo 3' del brazo 1. La utilización de la pareja de nickasas junto con un DNA donante nos permitió obtener células Jurkat knockout para WASp. Hay ya numerosos ejemplos en la literatura del uso de este sistema en la generación de células knockout, pero generalmente utilizan el sistema CRISPR estándar, con actividad nucleasa del tipo DSB. Dicha lesión en el DNA se repara generalmente mediante la adición o deleción de uno, o unos pocos, nucleótidos en el sitio de corte, llamados indels (Ran et al., 2013). Así que, en muchas ocasiones hay un cambio en el marco de lectura en ese sitio, lo que da lugar generalmente a la creación de un alelo nulo. Sin embargo, habrá casos en que la reparación de lugar a una secuencia normal no mutada. En cualquier 
caso, será necesario llevar a cabo un laborioso proceso de subclonaje para poder aislar clones individuales, los cuales deberán ser posteriormente secuenciados para poder comprobar cuáles son los que han introducido una mutación en el sitio. Nosotros decidimos aplicar el método alternativo de las CRISPR nickasas simultáneamente, con el fin de crear dos nicks, uno en una de las hebras y el otro en la complementaria. Ambos nicks están separados por una corta distancia, lo que permite que se comporten como un DSB, que puede corregirse por recombinación homóloga en presencia de un DNA donante. La ventaja de este método, es que podemos controlar mejor el tipo de mutación que queremos introducir y, además, nos permite introducir un gen de selección para enriquecer en positivos al crecer las células en presencia del antibiótico de selección. Además, en caso de que se produjeran cortes tipo nicks en otros sitios del genoma de forma inespecífica, este tipo de lesión suele corregirse de forma fiel, sin introducción de mutaciones, lo cual es una enorme ventaja para la futura aplicación del método en células humanas, potencialmente usadas en terapia celular

La decisión de utilizar la línea celular Jurkat tiene que ver, en primer lugar, con el hecho de que, al ser una línea celular es de fácil mantenimiento en cultivo, lo cual es una gran ventaja si lo comparamos con los fibroblastos primarios, ya que estos tienen un tiempo de replicación mucho mayor, la mortalidad es mucho más elevada, y se replican un número limitado de veces para entrar, luego, en senescencia. En segundo lugar, la elección de las células Jurkat tuvo que ver con que, al ser una línea de células $\mathrm{T}$, de estirpe hematopoyética, expresan la proteína WASp en grandes cantidades, lo cual hizo que fuera más fácil controlar si los cambios génicos introducidos producían variaciones en la expresión de la proteína mediante la simple realización de un Western Blot. Puesto que WASp es una proteína clave en la función de las células hematopoyéticas, tanto en la señalización a través de los receptores de antígeno de los linfocitos, como por su participación en numerosas vías de transducción de señales y por su función en la regulación del citoesqueleto de actina, es de gran importancia contar con una línea deficiente en dicha proteína que permitirá la realización de ensayos funcionales en nuestro grupo o en colaboración con otros laboratorios.

El hecho de haber realizado las modificaciones génicas en fibroblastos utilizando rAAVs, se basó en el amplio tropismo celular que han demostrado este tipo de virus, junto con su capacidad para infectar células que están o no en división. Otra de las razones por las cuales utilizamos estos vectores, fue la eficacia terapéutica conseguida con la transferencia génica mediante la utilización de vectores rAAVs, 
documentada en diversos estudios preclínicos, muchos de los cuales fueron exitosamente trasladados a la clínica (Mingozzi et al., 2011). Sin embargo, la respuesta inmune desencadenada frente a los rAAVs podría constituir un obstáculo importante en la eficacia a largo plazo y en la seguridad del tratamiento, ya que la prevalencia de anticuerpos anti-AAV en la población humana es elevada, y con mayor reactividad frente al AAV2 que es el serotipo más estudiado y mejor caracterizado de todos los serotipos de AAV (Tseng et al., 2014). A pesar de que se sugiere que la inmunidad innata frente al AAV puede desencadenar la respuesta inmune adaptativa dirigida contra la cápside o contra el producto del transgén, no existe evidencia de que la administración de un rAAV en humanos resulte en reacción inflamatoria aguda, aunque restan estudios por realizarse en este campo (Nathwani et al., 2011; Buchlis et al., 2012).

Actualmente, se está utilizando el primer producto para terapia génica con licencia autorizada en la UE, Glybera, el cual se utiliza para ciertas formas de una rara enfermedad metabólica, la hipercolesterolemia familiar, en la que existe deficiencia de la enzima lipoproteinlipasa (Bryant et al., 2013). Sin embargo, la producción de un alto título viral sigue siendo el gran desafío, tanto a nivel experimental, como en el caso de Glybera, donde se requiere la administración de muchas dosis (40-60) de elevado título viral, aproximadamente, unas $10^{12}$ partículas virales/mL (Satkunanathan et al., 2014).

\section{Transdiferenciación de fibroblastos corregidos a células hematopoyéticas.}

La transdiferenciación es el proceso por el cual es posible convertir una célula somática en otra de estirpe diferente sin pasar por un estado de pluripotencia intermedio, a través de una regulación a la baja (down-regulation) de un programa genético y simultánea regulación a la alta (up-regulation) del nuevo programa genético (Jopling et al., 2011). En otras palabras, la reprogramación de una célula somática es un proceso en el cual ocurren extensas modificaciones epigenéticas, que junto con la remodelación de la cromatina dan cabida a la activación de genes de pluripotencia, a la vez que se inactivan los genes específicos de linaje (Karamariti et al., 2013). Es esto es lo que buscamos lograr, convirtiendo fibroblastos humanos en progenitores hematopoyéticos, utilizando Oct4 como único factor asociado a pluripotencia y al desarrollo embrionario temprano. Aunque no existe una relación conocida entre Oct4 y hematopoyesis, Oct4 ha sido descrito como capaz de promover la expresión de 
reguladores hematopoyéticos en presencia de condiciones de cultivo permisivas óptimas para el mantenimiento in vitro de progenitores hematopoyéticos humanos adultos (Mitchell et al., 2014).

Aunque este método es muy reciente para células humanas, ya se ha aplicado con éxito anteriormente utilizando fibroblastos embrionarios y fibroblastos adultos de ratón. Estos fueron eficientemente transdiferenciados a progenitores hematopoyéticos mediante la expresión ectópica de diferentes factores de transcripción, y posteriormente, fueron expandidos de forma estable. Se observó además que poseían la capacidad de reconstitución hematopoyética de todas las series diferenciadas, in vivo, a corto plazo (Batta et al., 2014).

Este nuevo método se ha ensayado para transdiferenciar fibroblastos a distintos linajes, como ser progenitores neurales (y posterior diferenciación a astrocitos y oligodendrocitos) y endodermo (y posterior diferenciación a hepatocitos) llevada a cabo por parte de Mitchell et al., 2014. También a partir de fibroblastos se han obtenido células endoteliales (Margariti et al., 2014). Por otro lado, también se lograron transdiferenciar fibroblastos embrionarios de ratón a cardiomiocitos (Ifkovits et al., 2014) y a células de los islotes pancreáticos (Lumelsky, 2014).

La utilización de un vector lentiviral que codifica para la proteína Oct4 nos permitió su expresión continua una vez transducidos los fibroblastos humanos con el lentivirus. De cara a una posible aplicación futura de esta tecnología, existe el inconveniente de que Oct4 es un factor de transcripción asociado a pluripotencialidad y su expresión constante podría ser causa de generación de tumores. Este problema podría evitarse, teóricamente, si en lugar de utilizar un lentivirus se utilizara la proteína Oct4 recombinante. Ya hay antecedentes del uso de factores de transcripción en forma de proteínas recombinantes: se han logrado reprogramar fibroblastos embrionarios de ratón utilizando proteínas de fusión de Oct4, KIf4, Sox2, Myc (Zhou et al., 2009); por otro lado, se han reprogramado fibroblastos fetales humanos, cultivándolos con las proteínas recombinantes Oct4, KIf4, Sox2, Myc (Kim et al., 2009). Sin embargo, este método a pesar de ser más seguro, tiene la desventaja de la corta vida media de las proteínas, lo cual requiere de múltiples aplicaciones al medio de cultivo, y, más aún, la dificultad a la hora de producir y purificar dichas proteínas (Parameswaran et al., 2011).

Nuestra experiencia durante la realización de la presente tesis es que, la expresión de Oct4 por parte de los fibroblastos corregidos (Fibs-WASP+) junto con la presencia de un medio con las citoquinas óptimas (bFGF, IGFII, SCF e IIt3L), han sido suficientes 
para convertir los fibroblastos en células progenitoras hematopoyéticas CD45 $5^{+}$. Un $30 \%$ de las células en el cultivo presentan este marcador después de 37 días de la transducción lentiviral de Oct4. De igual manera hemos comprobado que, aproximadamente, el $90 \%$ de las células obtenidas expresaban WASp, que como se recordará, es de expresión exclusivamente hematopoyética. Esto está de acuerdo con los datos obtenidos por otros laboratorios que han utilizados diferentes métodos (Muñoz et al., 2012), y que indican que la aparición de WASP es anterior a la de CD45 en progenitores hematopoyéticos $\left(\mathrm{CD} 45^{-} \mathrm{CD} 31^{+}\right)$, si bien la expresión máxima de la proteína se da en las células $C D 45^{+}$. Actualmente, y gracias a la generosa colaboración del Dr. Martín, contamos con el lentivirus AWE (Muñoz et al., 2012), que contiene un fragmento del promotor del gen WAS (conformado por 500 bp pertenecientes al promotor proximal, junto con $387 \mathrm{bp}$ pertenecientes al promotor alternativo), el cual dirige la expresión de una EGFP que se expresa, por tanto, específicamente en células hematopoyéticas y que nos permitirá, evaluar la población heterogénea de células que hemos obtenido luego del proceso de transdiferenciación. Con ello podremos corroborar la expresión de WASp a la vez que se comprueba la expresión de diferentes marcadores hematopoyéticos de membrana, lo cual no hemos podido llevar a cabo de manera eficiente en nuestros experimentos. Las razones de utilizar este método son, que la señal obtenida con el anticuerpo $\alpha$-WASp es siempre muy débil y hace difícil observar pequeñas diferencias de expresión de WASp entre las diferentes poblaciones, y en segundo lugar, la imposibilidad de realizar dobles marcajes debido a la pérdida de la señal del anticuerpo $\alpha$-CD45 cuando se fija y permeabiliza la célula para la tinción intracelular con $\alpha$-WASp, por lo que no hemos podido estudiar dobles marcajes CD45/WASp.

Aunque este protocolo de transdiferenciación (Szabo et al., 2010) es de gran importancia en cuanto a que supone una posible alternativa futura de obtener precursores hematopoyéticos in vitro a partir de células somáticas, hay que destacar que todavía quedan muchos obstáculos por superar; por ejemplo, aunque los autores han descrito la obtención de progenitores hematopoyéticos multipotentes de las líneas mieloide, eritroide y megacariocítica, cuando se han trasplantado estos precursores en ratones inmunodeficientes, sólo se ha obtenido una modesta diferenciación mieloide (eritrocitos, megacariocitos, monocitos y granulocitos) sin recuperación de la estirpe linfoide (linfocitos B y T); sin embargo, es importante destacar que los precursores hematopoyéticos generados in vitro no se transformaron en células tumorales.

Se sabe que hoy en día están llevándose a cabo diferentes protocolos de terapia génica en pacientes con diversas patologías, y aunque bien sabemos que a nuestra 
investigación le queda mucho camino por recorrer, no nos olvidamos de la posibilidad de que, después de mucho trabajo, con la correcta puesta a punto y pruebas previas necesarias, pueda ser utilizado para corregir fibroblastos de pacientes enfermos de WAS y, posteriormente, transdiferenciarlos a células $C D 45^{+}$, y que estas células sean introducidas en el paciente, con lo cual se podría recuperar la capacidad de expresar WASp en las diferentes líneas hematopoyéticas, y con ello, conseguir revertir o, al menos, disminuir las manifestaciones de la enfermedad. 


\section{CONCLUSIONES.}

"Sorprendernos por algo es el primer paso de la mente hacia el descubrimiento

Louis Pasteur (1822 - 1895) 
A continuación se presentan las conclusiones obtenidas en cada uno de los objetivos planteados en el presente trabajo de tesis:

1. Se ha generado una línea celular reportera humana, HCT116-RCL, que contiene un gen de EGFP mutado, y por tanto, es incapaz de producir una proteína funcional (verde). Así también, se ha producido un virus adenoasociado recombinante, AAV- $\Delta 5$-EGFP-donor, que ha permitido la corrección genética de EGFP mediante $\mathrm{RH}$, con la consecuente recuperación de la fluorescencia verde.

2. Se ha estudiado el efecto sobre la frecuencia de RH de diferentes tratamientos en nuestro sistema experimental línea reportera - vector donante:

a. Se ha producido una pareja de TALENs capaz de producir un corte en la doble hebra de DNA, con el consecuente aumento en la frecuencia de $\mathrm{RH}$.

b. Se ha producido y estudiado la proteína de fusión ScRad52, encontrándose que la misma es funcional y que es capaz de aumentar la frecuencia de $\mathrm{RH}$.

c. Se ha estudiado el comportamiento de una librería de 84 siRNAs diferentes, frente a genes implicados en la vía de la recombinación no homóloga, así como frente a otros de funciones diferentes, pero que se conoce que están indirectamente implicados en el aumento de $\mathrm{RH}$, habiéndose comprobado que algunos de los siRNAs, ya sea de manera individual o formando parte de una combinación de varios de ellos, han logrado aumentar la frecuencia de $\mathrm{RH}$.

3. Se ha inducido una modificación génica dirigida en el WAS, basándonos en técnicas de edición génica mediante $\mathrm{RH}$. Se ha aplicado con éxito un protocolo para la transdiferenciación de fibroblastos primarios corregidos del defecto genético:

a. Se evaluaron los protocolos de RH utilizados previamente, tras lo cual se han generado fibroblastos primarios WASP-KO, con la ayuda del silenciamiento de ciertos genes mediante siRNAs y posterior transducción con el virus adenoasociado recombinante, AAV-WASP-KO.

b. Se han corregido los fibroblastos WASP-KO, también mediante la utilización de siRNAs y rAAV, utilizando en este caso el AAV-WASP-wt.

c. Se han transdiferenciado los fibroblastos primarios corregidos, Fibs-WASP+, a células multipotentes hematopoyéticas, $C D 45^{+}$, obteniéndos luego que un $90 \%$ de estas células expresan WASP, de las cuales un $30 \%$ son $C D 45^{+}$. 


\section{BIBLIOGRAFIÁA.}

"La ciencia se compone de errores, que a su vez son los pasos hacia la verdad"

Julio Verne $(1828$ - 1905) 
Adamson B, Smogorzewska A, Sigoillot FD, King RW, Elledge SJ. A genome-wide homologous recombination screen identifies the RNA-binding protein RBMX as a component of the DNA-damage response. Nature Cell Biology, 2012. 14, 318-28.

Aiuti A, Biasco L, Scaramuzza S, Ferrua F, Cicalese MP, et al. Lentiviral hematopoietic stem cell gene therapy in patients with Wiskott-Aldrich syndrome. Science, 2013. 341.

Akamatsu Y, Jasin M. Role for the mammalian Swi5-Sfr1 complex in DNA strand break repair through homologous recombination. PLos genetics, 2010. 6, e1001160.

Antón IM, de la Fuente MA, Sims TN, Freeman S, Ramesh H, et al. WIP (WASP interacting protein) deficiency reveals a differential role for WIP and the actin cytoskeleton in T and B cell activation. Immunity, 2002. 16, $193-204$.

Ariga T. Wiskott-Aldrich syndrome; an X-linked primary immunodeficiency disease with unique and characteristic features. Allergology international, 2012. 6, 183 - 9.

Aurnhammer C, Haase M, Muether N, HausI M, Rauschhuber C, et al. Universal real-time PCR for the detection and quantification of adeno-associated virus serotype 2-derived inverted terminal repeat sequences. Human Gene Therapy Methods, 2012. 23, 18-28.

Avedillo Díez I, Zychlinski D, Coci EG, Galla M, Modlich U, et al. Development of novel efficient SIN vectors with improved safety features for Wiskott-Aldrich syndrome stem cell based gene therapy. Molecular pharmaceutics, 2011. 8, 1525-37.

Bahat A, Kedmi R, Gazit K, Richardo-Lax O, Ainbinder E, Dikstein R. TAFb and TAF4 differentially regulate mouse embryonic stem cells maintenance and proliferation. Genes to cells, 2013. 18, $225-37$.

Barrangou R, Fremaux C, Deveau H, Richards M, Boyaval P, et al. CRISPR provides acquired resistance against viruses in prokaryotes. Science, 2007. 315, 1709-12.

Basner-Tschakarjan E, Mingozzi F. Cell-mediated immunity to AAV vectors, evolving concepts and potential solutions. Frontiers in immunology, 2014. 5, 350.

Batta K, Florkowska M, Kouskoff V, Lacaud G. Direct reprogramming of murine fibroblasts to hematopoietic progenitors cells. Cell report, 2014. 9, $1871-84$.

Belshaw R, Pereira V, Katzourakis A, Talbot G, Paces J, et al. Long-term reinfection of the human genome by endogenous retroviruses. Proceedings of the National Academy of Sciences of the United States of America, 2004. 101, 4894-9.

Bertolini LR, Bertolini M, Maga EA, Madden KR, Murray JD. Increased gene targeting in Ku70 and Xrcc4 transiently deficient human somatic cells. Molecular biotechnology, 2009. 41, 106-14. 
Biasco L, Ambrosi A, Pellin D, Bartholomae C, Brigida I, et al. Integration profile of retroviral vector in gene therapy treated patients is cell-specific according to gene expression and chromatin conformation of target cell. EMBO Molecular Medicine, 2011. 3, 89-101.

Bibikova M, Carroll D, Segal DJ, Trautman JK, Smith J, et al. Stimulation of homologous recombination through targeted cleavage by chimeric nucleases. Molecular and cell biology, 2001. 21, 289-97.

Bibikova M, Beumer K, Trautman JK, Carroll D. Enhancing gene targeting with designed zinc finger nucleases. Science 2003. 300, 764.

Blundell MP, Worth A, Bouma G, Thrasher AJ. The Wiskott-Aldrich syndrome: The actin cytoskeleton and immune cell function. Disease markers, 2010. 29, 157-75.

Boch J, Bonas U. Xanthomonas AvrBs3 family-type III effectors: discovery and function. Annual Review Phytopathology 2010. 48, 419-36.

Borges JC, Fischer H, Craievich AF, Ramos CH. Low resolution structural study of two human HSP40 chaperones in solution. DJA1 from subfamily A and DJB4 from subfamily $B$ have different quaternary structures. The journal of biological chemistry, 2005. $280,13671-81$.

Bosticardo M, Marangoni F, Aiuti A, Grazia Roncarolo M. Recent advances in understanding the pathophysiology of Wiskott-Aldrich syndrome. Blood, 2009. 113, 6288-95.

Boye SE, Boye SL, Lewin AS, Hauswirth WW. A comprehensive review of retinal gene therapy. Molecular therapy, 2013. 21, $509-19$.

Boztug K, Schmidt M, Schwarzer A, Banerjee PP, Díez IA, et al. Stem-cell gene therapy for the Wiskott-Aldrich syndrome. The New England journal of Medicine, 2010. 363, 191827.

Brunet E, Simsek D, Tomishima M, DeKelver R, Choi VM, et al. Proceedings of the National Academy of Sciences of the United States of America, 2009. 106, 10620-5.

Bryant LM, Christopher DM, Giles AR, Hinderer C, Rodriguez JL, et al. Lessons learned from the clinical development and market authorization of Glybera. Human gene therapy. Clinical development, 2013. 24, 55-64.

Buchlis G, Podsakoff GM, Radu A, Hawk SM, Flake SM, et al. Factor IX expression in skeletal muscle of a severe hemophilia B patient 10 years after AAV-mediated gene transfer. Blood, 2012. 119, 3038-41. 
Bultmann S, Morbitzer R, Schmidt CS, Thanisch K, Spada F, et al. Targeted transcriptional activation of silent oct4 pluripotency gene by combining designer TALEs and inhibition of epigenetics modifiers. Nucleic Acids Research, 2012. 40, 5368-77.

Büning H, Ried MU, Perabo L, Gerner FM, Huttner NA, et al. Receptor targeting of adenoassociated virus vectors. Gene therapy, 2003.10, 1142-51.

Catucci M, Castiello MC, Pala F, Bosticardo M, Villa A. Autoimmunity in Wiskott-Aldrich syndrome: an unsolved enigma. Frontiers in immunology, 2012. 209.

Cermak T, Doyle EL, Christian M, Wang L, Zhang Y, et al. Efficient design and assembly of custom TALEN and other TAL effector-based constructs for DNA targeting. Nucleic Acids Research, 2011. 39, e82.

Chapman JR, Taylor MR, Boulton SJ. Playing the end game: DNA double-stranded break repair pathway choice. Molecular cell, 2012. 47, 497-510.

Choi JH, Yu NK, Baek GC, Bakes J, Seo D, et al. Optimization of AAV expression cassettes to improve packaging capacity and transgene expression in neurons. Molecular brain, 2014. 7,17.

Chtarto A, Bockstael O, Tshbangu T, Dewitte O, Levivier M, Tenenbaum L. A next step in adeno-associated virus-mediated gene therapy for neurological diseases: regulation and targeting. British journal of clinical pharmacology, 2013. 76, $217-32$.

Coker H, Brockdorff N. SMCHD1 accumulates at DNA damage sites and facilitates the repair of DNA double-strand breaks. Journal of cell science, 2014. 127, 1869-74.

Cong L, Ran FA, Cox D, Lin S, Barretto R, et al. Multiplex genome engineering using CRISPR/Cas system. Science, 2013. 330, 819-23.

Cordeiro N, Taroco R. Temas de bacteriología y virología médica. Retrovirus y VIH. Oficina del libro FEFMUR. 2006. 2 edición. 449-476.

Darzynkiewicz Z, Halicka HD, Zhao H, Podhorecka M. Cell synchronization by inhibitors of DNA replication induces replication stress and DNA damage response: analysis by flow cytometry. Methods in molecular biology, 2011. 761, 85 - 96.

Davidson I, Kobi D, Fadloun A, Mengus G. New insights into TAFs as regulators of cell cycle and signaling pathways. Cell cycle, 2005. 4, 1486-90.

Davis TW, Wilson-Van Patten C, Meyers M, Kunugi KA, Cuthill S, et al. Defective expression of the DNA mismatch repair protein, MLH1, alters G2-M cell cycle checkpoint arrest following ionizing radiation. Cancer research, 1998. 58, 767-78 
Daya S, Berns KI. Gene Therapy Using Adeno-Associated Virus Vectors. Clinical Microbiology Reviews, 2008. 21, 583-593.

De loannes P, Malu S, Cortes P, Aggarwal AK. Structural basis of DNA ligase IV-Artemis interaction in nonhomologous end-joining. Cell reports, 2012.2,1505-12.

De la Fuente MA, Sasahara Y, Calamito M, Antón IM, Elkhal A, et al. WIP is a chaperone for Wiskott-Aldrich syndrome protein (WASP). Proceedings of the National Academy of Sciences of the United States of America, 2006.104, 926 ' 31.

Deak M, Clifton AD, Lucocq LM, Alessi DR. Mitogen- and stress-activated protein kinase-1 (MSK1) is directly activated by MAK and SAPK/p38, and may mediate activation of CREB. EMBO journal, 1998. 17, 4426-41.

Delacôte F, Han M, Stamato TD, Jasin M, Lopez BS. An xrcc4 defect or Wortmannin stimulates homologous recombination specifically induced by double-strand breaks in mammalian cells. Nucleic acids research, 2002. 30, $3454-63$.

Delacôte F, Perez C, Guyot V, Mikonio C, Potrel P, et al. Identification of Genes Regulating Gene Targeting by a High-Throughput Screening Approach. Journal of Nucleic Acids 2011. 2011, 947212.

Derry JM, Ochs HD, Francke U. Isolation of a novel gene mutated in Wiskott-Aldrich syndrome. Cell, 1994. 78, 635-44.

Di Primio C, Galli A, Cervelli T, Zoppé M, Rainaldi G. Potentiation of gene targeting in human cells by expression of Saccharomyces cerevisiae Rad52. Nucleic acids research, 2005. 33, 4639-48.

Farinelli G, Capo V, Scaramuzza S, Aiuti A. Lentiviral vectors for the treatment of primary immunodeficiencies. Journal of Inherited Metabolic Disease, 2014. 37, 525-33.

Fattah FJ, Lichter NF, Fattah KR, Oh S, Hendrickson EA. Ku70, an essential gene, modulates the frequency of rAAV-mediated gene targeting in human somatic cells. Proceedings of the National Academy of Sciences of the United States of America, 2008. 105, 8703-8.

Felice B, Cattoglio C, Cittaro D, Testa A, Miccio A, et al. Transcription factor binding sites are genetic determinants of retroviral integration in the human genome. PLoS One, 2009. 4, e4571.

Fischer U, Meese E. Glioblastoma multiforme: the role of DSB repair between genotype and phenotype. Oncogene, 2007. 26, 7809-15. 
Fischer U, Rheinheimer S, Krempler A, Löbrich M, Meese E. Glioma-amplified sequence KUB3 influences double-strand break repair after ionizing radiation. International journal of oncology, 2013. 43, 50-6.

Gaj T, Gersbach CA, Barbas III CF. ZFN, TALEN, and CRISPR/Cas-based methods for genome engineering. Trends in Biotechnology 2013. 31, 397-405.

Gamundi, M.C. Farmacia hospitalaria 2002. Tomo II, 919-927.

Gasiunas G, Barrangou R, Horvath P, Siksnys V. Cas9-crRNA ribonucleoprotein complex mediates specific DNA cleavage for adaptive immunity in bacteria. Proceedings of the National Academy of Sciences of the United States of America, 2012. 109, E2579-86.

Gendrel AV, Tang YA, Suzuki M, Godwin J, Nesterova TB, et al. Epigenetic functions of smchd1 repress gene clusters on the inactive $X$ chromosome and on autosomes. Molecular and cellular biology, 2013. 33, 3150-65.

Hacein-Bey-Abina S, Von Kalle C, Schmidt M, McCormack MP, Wulffraat N, et al. LMO2Associated Clonal T Cell Proliferation in Two Patients after Gene Therapy for SCID-X1. Science, 2003. 302: 415-9.

Harrison MM, Jenkins BV, O'Connor-Giles KM, Wildonger J. A CRISPR view of development Gene development, 2014. 28, 1859-72.

Hartlerode AJ, Scully R. Mechanisms of double-strand break repair in somatic mammalian cells. The Biochem journal, 2009. 423, 157-68.

Hawn MT, Umar A, Carethers JM, Marra G, Kunkel TA, et al. Evidence for a connection between the mismatch repair system and the G2 cell cycle checkpoint. Cancer research, 1995. 55, $3721-5$.

Henckaerts E, Linden RM. Adeno-associated virus: a key to the human genome? Future virology, 2010. 5, 555-74.

Hinrichsen I, Ernst BP, Nuber F, Passmann S, Schäfer D, et al. Reduced migration of MLH1 deficient colon cancer cells depends on SPTAN1. Molecular cancer, 2014. 13, 11.

Humbert O, Davis L, Maizels N. Targeted gene therapies: tools, application, optimization. Critical reviews in biochemistry and molecular biology, 2012. 47, 264-81.

Ifkovits JL, Addis RC, Epstein JA, Gearhart JD. Inhibition of TGF $\beta$ signaling increases direct conversion of fibroblasts to induce cardiomyocytes. PLoS One, 2014. 9, e89678.

Imai K, Nonoyama S, Ochs HD. WASP (Wiskott-Aldrich syndrome protein) gene mutation and phenotype. Current opinion in allergy and clinical immunology, 2003. 3, 427-36. 
Inoue-Yokoo T, Tani K, Sugiyama D. Mesodermal and hematopoietic differentiation from ES and iPS cells. Stem cell review, 2013. 9, $422-34$.

King KY, Goodell MA. Direct conversión of skin cells into blood: alchemy or science? Molecular Therapy, 2011. 19, 227 - 8.

Janovitz T, Sadelain M, Falck-Pedersen E. Adeno-associated virus type 2 preferentially integrates single genome copies with defined breakpoints. Virology journal, 2014. 11, 15.

Jasin M, de Villiers J, Weber F, Schaffner W. High frequency of homologous recombination in mammalian cells between endogenous and introduced SV40 genomes. Cell, 1985. 43, 695-703.

Jasin M, Rothstein R. Repair of strand breaks by homologous recombination. Cold Spring Harbor perspectives in biology, 2013. 5, a012740.

Jayathilaka K, Sheridan SD, Bold TD, Bochenska K, Logan HL, et al. A chemical compound that stimulates the human homologous recombination RAD51. Proceedings of the National Academy of Sciences of the United States of America, 2008. 105, 15848-53.

Jia J, Jin Y, Bian T, Wu D, Yang L, et al. Bacterial delivery of TALEN proteins for human genome editing. PLoS One, 2014. 9, e91547.

Jin Y, Mazza C, Christie JR, Giliani S, Fiorini M, et al. Mutations of the Wiskott-Aldrich Sindrome Protein (WASP): hotspots, effect on transcription and translation and phenotype/genotype correlation. Blood, 2004. 104, 4010 - 9.

Jinek M, Chylinski K, Fonfara I, Hauer M, Doudna JA, Charpentier E. A programmable dual-RNA-guided DNA endonuclease in adaptive bacterial immunity. Science, 2012. 337, 816-21.

Jopling C, Boue S, Izpisua Belmonte JC. Dedifferentiation, transdifferentiation and reprogramming: three routes to regeneration. Nature reviews. Molecular cell biology, 2011. 12, 79-89.

Kalvala A, Rainaldi G, Di Primio C, Liverani V, Falaschi A, Galli A. Enhancement of gene targeting in human cells by intranuclear permeation of the Saccharomyces cerevisiae Rad52 protein. Nucleic acids research, 2010. 38, e149.

Karamariti E, Margariti A, Winkler B, Wang X, Hong X, et al. Smooth muscle cells differentiated from reprogrammed embryonic lung fibroblasts through DKK3 signaling 
are potent for tissue engineering of vascular grafts. Circulation research, 2013. 112, $1433-43$.

Karamouzis MV, Konstantinopoulos PA, Papavassiliou AG. Roles of CREB-binding protein (CBP)/p300 in respiratory epithelium tumorigenesis. Cell research, 2007. 17, $324-32$.

Khalil AA, Kabapy NF, Deraz SF, Smith C. Heat shock proteins in oncology: diagnostic biomarkers or therapeutic targets? Biochimica et biophysica acta, 2011. 1816, 89-104.

Khan IF, Hirata RK, Russell DW. AAV-mediated gene targeting methods for human cells. Nature Protocols, 2011. 6, 482-501.

Kim D, Kim CH, Moon JI, Chung YG, Chang MY, et al. Generation of human induced pluripotent stem cells by direct delivery of reprogramming proteins. Cell stem cell, 2009. $4,472-6$.

Kurosawa A, Saito S, So S, Hashimoto M, Iwabuchi K, et al. DNA ligase IV and artemis act cooperatively to suppress homologous recombination in human cells: implications for DNA double-strand break repair. PLoS One, 2013. 8, e72253.

Langerak P, Russell P. Regulatory networks integrating cell cycle control with DNA damage checkpoints and double-strand break repair. Philosophical transactions of the Royal Society of London, Series B, Biological sciences, 2011. 366, 3562-71.

Lazo, P.A. Terapia génica humana: tendencias y problemas. Medicina Clínica (Barc). 106, 469-476 (1996).

Lee HJ, Kim E, Kim JS. Targeted chromosomal deletions in human cells using zinc-finger nucleases. Genome Research, 2010. 20, 8109.

Lee HJ, Kweon J, Kim E, Kim S, Kim JS. Targeted chromosomal duplications and inversions in the human genome using zinc finger nucleases. Genome Research, 2012. 22, 53948.

Lerch TF, O'Donell JK, Meyer NL, Xie Q, Taylor KA, et al. Structure of AAV-DJ, a retargeted gene therapy vector: cryo-electron microscopy at $4.5 \AA$ resolution. Structure, 2012. $20,1310-20$.

Li X, Zhang G, Ngo N, Zhao X, Kain SR, Huang CC. Deletions of the Aequorea victoria green fluorescent protein define the minimal domain required for fluorescence. Journal of Biological Chemistry 1997. 272, 28545-9.

Liu Y. Ligation independent cloning: an efficient tool for high-throughput cloning and modular cDNA assembly. OA Biotechnology, 2013. 2, 8-13. 
Lok BH, Powell SN. Molecular pathways: understanding the role of Rad52 in homologous recombination for therapeutic advancement. Clinical cancer research, 2012. 18, 64006.

Lombardo A, Cesana D, Genovese P, Di Stefano B, Provasi E, et al. Site-specific integration and tailoring of cassette design for sustainable gene transfer. Nature methods, 2011. 8, 861-9.

Lombardo A, Genovese P, Beausejour CM, Colleoni S, Lee YL, et al. Gene editing in human stem cells using zinc finger nucleases and integrase-defective lentiviral vector delivery. Nature Biotechnology 2007. 25, 1298-306.

Loonstra A, Vooijs M, Beverloo HB, Allak BA, van Drunen E, et al. Growth inhibition and DNA damage induced by Cre recombinase in mammalian cells. Proceedings of the National Academy of Sciences of the United States of America, 2001. 98, 9209-14.

Lumelsky N. Small molecules convert fibroblasts into islet-like cells avoiding pluripotent state. Cell metabolism, 2014. 19, 551-2.

Makarova KS, Haft DH, Barrangou R, Brouns SJ, Charpentier E, et al. Evolution and classification of the CRISPR-Cas systems. Nature reviews. Microbiology, 2011. 9, 467477.

Margariti A, Winkler B, Karamariti E, Zampetaki A, Tsai TN, et al. Direct reprogramming of fibroblasts into endothelial cells capable of angiogenesis and reendothelization in tissue-engineered vessels. Proceedings of the National Academy of Sciences of the United States of America, 2012. 109, 13793 - 8.

Massaad MJ, Ramesh N, Geha RS. Wiskott-Aldrich syndrome: a comprehensive review. Annals of the New York Academy of Sciences, 2013. 1285, 26-43.

McCabe N, Turner NC, Lord CJ, Kluzek K, Bialkowska A, et al. Deficiency in the repair of DNA damage by homologous recombination and sensitivity to poly(ADP-ribose) polymerase inhibition. Cancer research, 2006. 66, 8109-15.

McCarty, DM. Self-complementary AAV vectors; advances and applications. Molecular therapy, 2008. 16, $1648-56$.

McCoy CE, Campbell DG, Deak M, Bloomberg GB, Arthur JS. MSK1 activity is controlled by multiple phosphorylation sites. The Biochemical journal, 2005. 15, $507-17$.

Mingozzi F, High KA. Therapeutic in vivo gene transfer for genetic disease using AAV: progress and challenges. Nature reviews. Genetics, 2011. 12, 341-55. 
Mitchell R, Szabo E, Shapovalova Z, Aslostovar L, Makondo K, Bhatia M. Molecular evidence for OCT4-induced plasticity in adult human fibroblasts required for direct cell fate conversion to lineage specific progenitors. Stem cell, 2014. 32, 2178-87.

Miyoshi H, Blömer U, Takahashi M, Gage FH, Verma IM. Development of a self-inactivating lentivirus vector. Journal of Virology, 1998. 72, 8150-7.

Moehle EA, Rock JM, Lee YL, Jouvenot Y, DeKelver RC, et al. Targeted gene addition into a specified location in the human genome using designed zinc-finger nucleases. Proceedings of the National Academy of Sciences of the United States of America, 2007. 104, 3055-60.

Mojica FJ, Diez-Villaseñor C, García-Martinez J, Almendros C. Short motif sequences determines the targets of the prokaryotic CRISPR defense system. Microbiology, 2009. 733-40.

Mori S, Wang L, Takeuchi T, Kanda T. Two novel adeno-associated viruses from cynomolgus monkey: pseudotyping characterization of capsid protein. Virology, 2004. $330,375-83$.

Moscou, M.J. and Bogdanove, A.J. A simple cipher governs DNA recognition by TAL effectors. Science 2009. 326, 1501.

Moynahan ME, Jasin M. Mitotic homologous recombination maintains genomic stability and suppresses tumorigenesis. Nature reviews. Molecular cell biology, 2010. 11, 196-207.

Muñoz P, Toscano MG, Real PJ, Benabdellah K, Cobo M, et al. Specific marking of hESCsderived hematopoietic lineage by WAS-promoter driven lentiviral vectors. PLoS One, 2012. 7, e39091.

Nache V, Kusch J, Hagen V, Benndorf K. Gating of cyclic nucleotide-gated (CNGA1) channels by cGMP jumps and depolarizing voltage steps. Biophysical journal, 2006. 90, 3146-54.

Naldini L, Blömer U, Gage FH, Trono D, Verma IM. Efficient transfer, integration, and sustain long-term expression of the transgene in adult rat brains injected with a lentiviral vector. Proceedings of the National Academy of Sciences of the United States of America, 1996. 93, 11382-8.

Nathwani AC, Rosales C, Mclntosh J, Rastegarlari G, Nathwani D, et al. Long-term safety and efficacy following systemic administration of a self-complementary AAV vector encoding human FIX pseudotyped with serotype 5 and 8 capsid proteins. Molecular therapy, 2011. 19, 876-85. 
Nathwani AC, Tuddenham EG, Rangarajan S, Rosales C, Mcintosh J, et al. Adenovirusassociated virus vector-mediated gene transfer in hemophilia B. The New England journal of medicine, 2011. 365, $2357-65$.

Ninomiya Y, Suzuki K, Ishii C, Inoue H. Highly efficient gene replacements in Neurospora strains deficient for nonhomologous end-joining. Proceedings of the National Academy of Sciences of the United States of America, 2004. 101, 12248-53.

Noell DL, Yiu IM. Human gene therapy for hereditary diseases: a review of trials. American Journal of Health-System Pharmacy 1998. 55, 899-904.

Novelli G, Gruenert DC. Genome medicine: gene therapy for the millennium. Pharmacogenomics 2002. 3, 15-18.

Parameswaran S, Balasubramanian S, Rao MS, Ahmad I. Concise review: non-cell autonomous reprogramming: a nuclei acid-free approach to induction of pluripotency. Stem cells, 2011. 29, $1013-20$.

Pattanayak V, Ramirez CL, Joung JK, Liu DR. Revealing off-target cleavage specificities of zinc-finger nucleases by in vitro selection. Nature Methods 2011. 8, 765-70.

Peitz M, Pfannkuche K, Rajewsky K, Edenhofer F. Ability of the hydrophobic FGF and basic TAT peptides to promote cellular uptake of recombinant Cre recombinase: a tool for efficient genetic engineering of mammalian genomes. Proceedings of the National Academy of Sciences of the United States of America, 2002. 99, 4489-94.

Quinonez R, Sutton RE. Lentiviral vectors for gene delivery into cells. DNA and cell biology, 2002. 21, 937-51.

Radecke S, Radecke F, Cathomen T, Schwarz K. Zinc-finger nuclease-induced gene repair with oligodeoxynucleotides: wanted and unwanted target locus modifications. Molecular Therapy 2010. 28, 743-53.

Rajabi HN, Baluchamy S, Kolli S, Naq A, Srinivas R, et al. Effects of depletion of CREBbinding protein on c-Myc regulation and cell cycle G1-S transition. The journal of biological chemistry, 2005. 280, 361-74.

Ran FA, Hsu PD, Wright J, Agarwala V, Scott DA, Zhang F. Genome engineering using the CRISPR-Cas9 system. Proceedings of the National Academy of Sciences of the United States of America, 2013. 8, 2281-308.

Reyon D, Tsai SQ, Khayter C, Foden JA, Sander JD, Joung JK. FLASH assembly of TALENs for high-throughput genome editing. Nature Biotechnology, 2012. 30, 460-5. 
Riddell J, Gazit R, Garrison BS, Guo G, Saadatpour A, et al. Reprogramming committed murine blood cells to induced hematopoietic stem cells with defined factors. Cell, 2014. $157,549-64$.

Rohr UP, Kronenwett R, Grimm D, Kleinschmidt J, Haas R. Primary human cells differ in their susceptibility to rAAV-2-mediated gene transfer and duration of reporter gene expression. Journal of Virological Methods, 2002. 105, 265-75.

Sadelain M, Papapetrou EP, Bushman FD. Safe harbours for the integration of new DNA in the human genome. Nature reviews. Cancer, 2011. 12, $51-8$.

Santiago Y, Chan E, Liu PQ, Orlando S, Zhang L, et al. Targeted gene knockout in mammalian cells by using engineered zinc-finger nucleases. Proceedings of the National Academy of Sciences of the United States of America, 2008. 105, 5809-14.

Satkunanathan S, Wheeler J, Thorpe R, Zhao Y. Establishment of a novel cell line for enhanced production of recombinant adeno-associated virus vectors for gene therapy. Human gene therapy, 2014. 25, 929-41.

Scaramuzza S, Biasco L, Ripamonti A, Castiello MC, Loperfido M, et al. Preclinical safety and efficacy of human CD34(+) cells transduced with lentiviral vector for the treatment of Wiskott-Aldrich syndrome. Molecular Therapy, 2013. 21, 175-84.

Schmid-Burgk JL, Schmidt T, Kaiser V, Höning K and Hornung V. A ligation-independent cloning technique for high-throughput assembly of transcription activator-like effector genes. Nature Biotechnology 2013. 31, 76-81.

Shrivastav M, De Haro LP, Nickoloff JA. Regulation of DNA double-strand break repair pathway choice. Cell research, 2008. 18, 134-47.

Silva G, Poirot L, Galetto R, Smith J, Montoya G, et al. Meganucleases and other tools for targeted genome engineering: perspectives and challenges for gene therapy. Current gene therapy, 2011. 11, $11-27$.

Słabicki M, Theis M, Krastev DB, Samsonov S, Mundwiller E, et al. A genome-scale DNA repair RNAi screen identifies SPF48 as a novel gene associates with hereditary spastic paraplegia. PLos Biology, 2010. 8, e1000408.

Snapper SB, Rosen FS. The Wiskott-Aldrich syndrome protein (WASP): roles in signaling and cytoskeletal organization. Annual review of immunology, 1999. 17, 905-29.

Sterrenberg JN, Blatch GL, Edkins AL. Human DNAJ in cancer and stem cells. Cancer letters, 2011. 312, $129-42$. 
Sturgeon CM, Ditadi A, Clarke RL, Keller G. Defining the path to hematopoietic stem cells. Nature biotechnology, 2013. 31, $416-8$.

Sugiyama T, New JH, Kowalczykowski SC. DNA annealing by RAD52 protein is stimulated by specific interaction with the complex of replication protein $A$ and single-stranded DNA. . Proceedings of the National Academy of Sciences of the United States of America, 1998.

Sun N, Zhao H. Transcription activator-like effector nucleases (TALENs): a highly efficient and versatile tool for genome editing. Biotechnology and Bioengineering 2013. 110, 181121.

Symington LS. Role of RAD52 epistasis group genes in homologous recombination and double-strand break repair. Microbiology and Molecular Biology Reviews, 2002. 66, 630-670.

Szabo E, Rampalli S, Risueño RM, Schnerch A, Mitchell R, et al. Direct conversion of human fibroblasts to multilineage blood progenitors. Nature, 2010. 468, 521-6.

Takahashi K, Yamanaka S. Induction of pluripotent stem cells from mouse embryonic and adult fibroblasts cultures by defined factors. Cell, 2006. 126, 663- 76 .

Tang M, Li Y, Zhang X, Deng T, Zhou Z, Ma W, Songyang Z. Structural maintenance of chromosomes flexible hinge domain containing 1 (SMCHD1) promotes nonhomologous end joining and inhibits homologous recombination repair upon DNA damage. The journal of biological chemistry, 2014. 289, 34024-32.

Tang Y, Garson K, Li L, Vanderhyden BC. Optimization of lentiviral vector production using polyethylenimine-mediated transfection. Oncology letters, 2015. 9, 55-62.

Teschendorf C, Warrington KH Jr, Shi W, Siemann DW, Muzyczka N. Recombinant adeno-associated and adenoviral vectors for the transduction of pancreatic and colon carcinoma. Anticancer research, 2006. 26, 311-7.

Tsai SP, Su GC, Lin SW, Chung Cl, Xue X, et al. Rad51 presynaptic filament stabilization function of the mouse Swi5-Sfr1 heterodimeric complex. Nucleic acids research, 2012. 40, 6558-69.

Tseng YS, Agbandje-McKenna M. Mapping the AAV capsid host antibody response toward the development of second generation gene delivery vectors. Frontiers immunology, 2014. 5, 9. 
Turnell AS, Mymryk JS. Roles for the coactivators CBP and p300 and the APC/C E3 ubiquitin ligase in E1A-dependent cell transformation. British journal of cancer, 2006. $95,555-60$.

Valor LM, Viosca J, Lopez-Atalaya JP, Barco A. Lysine acetyltransferases CBP and p300 as therapeutic targets in cognitive and neurodegenerative disorders. Current pharmaceutical designs, 2013. 19, $5051-64$.

Vasileva A, Jessberger R. Precise hit: adeno-associated virus in gene targeting. Nature reviews Microbiology, 2005. 837-847.

Vilardi F, Lorenz H, Dobberstein B. WRB is the receptor for TRC40/Asna1-mediated insertion of tail-anchored proteins into the ER membrane. Journal of cell science, 2011. $124,1301-7$.

Wei C, Liu J, Yu Z, Zhang B, Gao G, Jiao R. TALEN or Cas9 - rapid, efficient and specific choices for genome modifications. Journal of genetics and genomics, 2013. 40, 281-9.

Weitzman MD, Kyöstiö SR, Kotin RM, Owens RA. Adeno-associated virus (AAV) Rep proteins mediate complex formation between AAV DNA and its integration site in human DNA. Proceedings of the National Academy of Sciences of the United States of America, 1994. 91, 5808-12.

Wu Z, Asokan A, Samulski RJ. Adeno-associated virus serotypes: vector toolkit for human gene therapy. Molecular therapy, 2006. 14, 316- 27.

Yáñez EJ, Porter AC. Gene targeting is enhanced in human cells overexpressing hRad51. Gene therapy, 1999. 6, 1282-90.

Yang CR, Yeh S, Leskov K, Odegaard E, Hsu HL, et al. Isolation of Ku70-binding proteins (KUBs). Nucleic acids research, 1999. 27, 2165-74.

Yang J, Zhou W, Zhang Y, Zidon T, Ritchie T, Engelhardt JF. Concatamerization of adenoassociated virus circular genomes occurs through intermolecular recombination. Journal of Virology, 1999. 73, 9468-9477.

Zhong L, Li B, Mah CS, Govindasamy L, et al. Next generation of adeno-associated virus 2 vectors: Point mutations in tyrosines lead to high-efficiency transduction at lower doses. Proceedings of the National Academy of Sciences of the United States of America, 2008. 105, $7827-32$.

Zhou H, Wu S, Joo JY, Zhu S, Han DW, et al. Generation of induced pluripotent stem cells using recombinant proteins. Cell stem cell, 2009. 4, 381 - 4 . 
Zhu Q, Watanabe C, Liu T, Hollenbaugh D, Blaese RM, et al. Wiskott-Aldrich syndrome/Xlinked thrombocytopenia: WASP gene mutations, protein expression and phenotype. Blood, 1997. 90, 2680-9.

Zychlinski D, Schambach A, Modlich U, Maetzig T, Meyer J, et al. Physiological promoters reduce the genotoxic risk of integrating gene vectors. Molecular Therapy, 2008. 16, 718-25. 


\section{ANEXOS.}

"Ciencia sin conciencia no es más que la ruina del alma"

François Rabelais (1494 - 1553) 


\section{Mapas de plásmidos comerciales utilizados.}
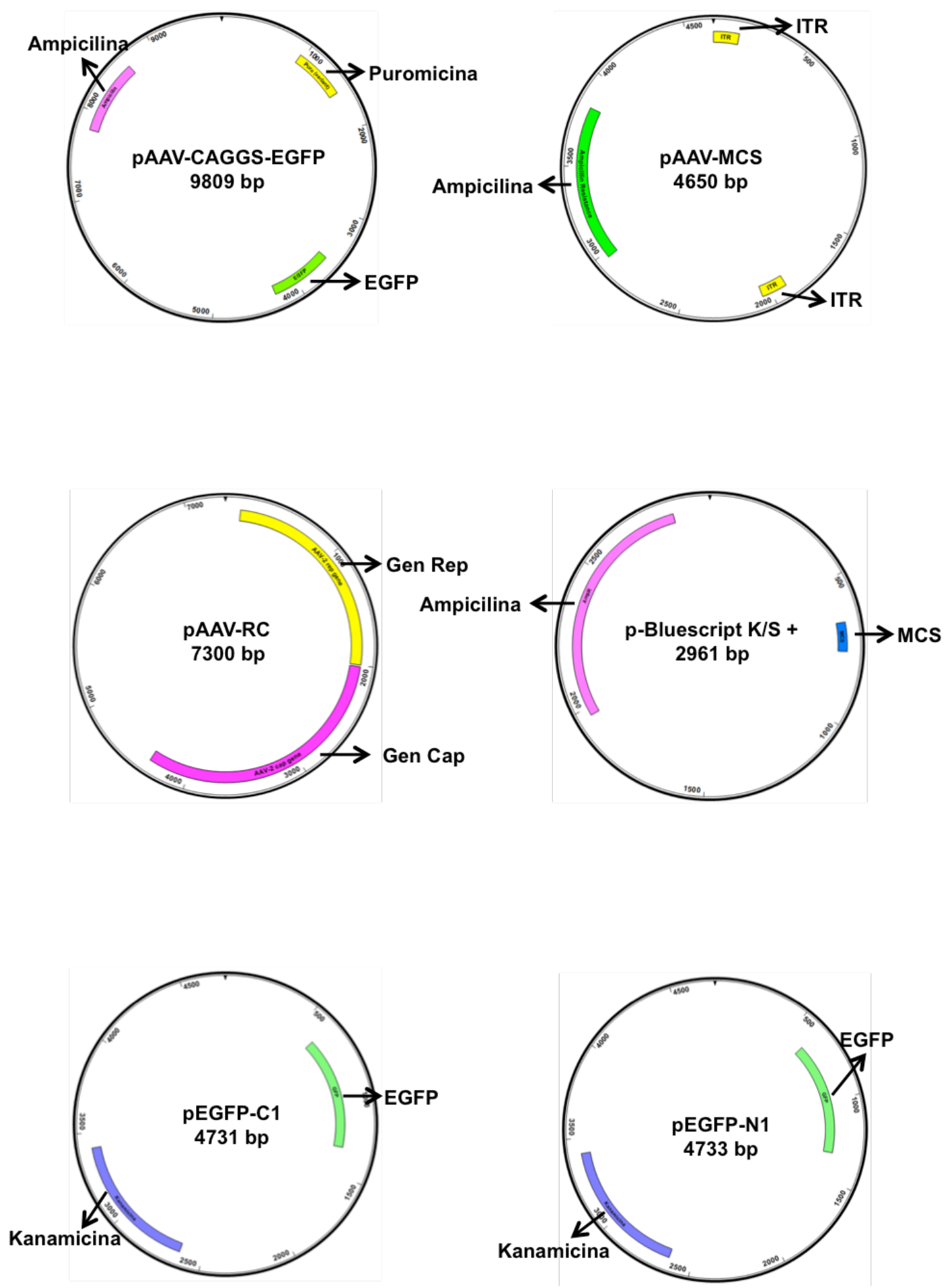

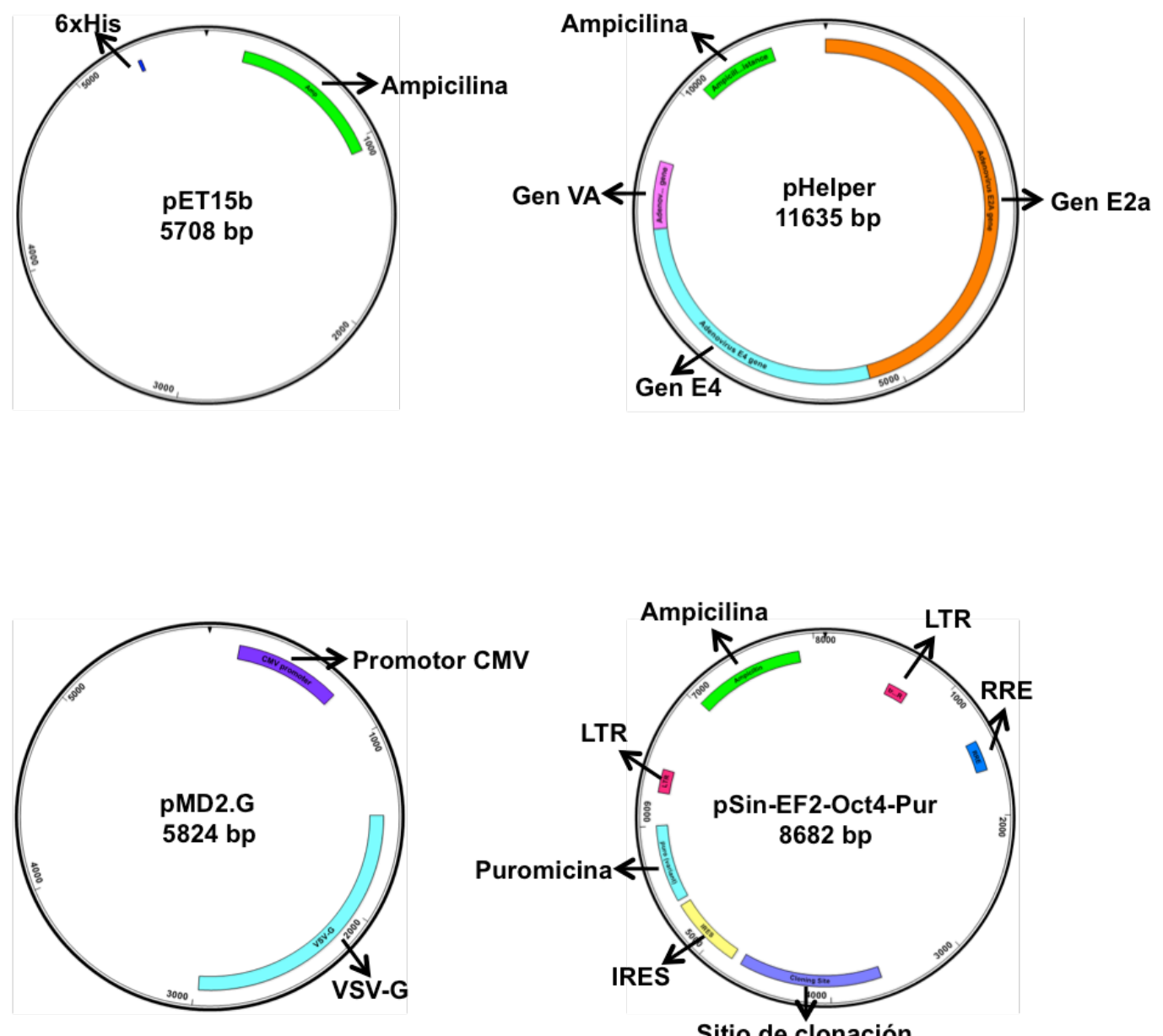

Sitio de clonación
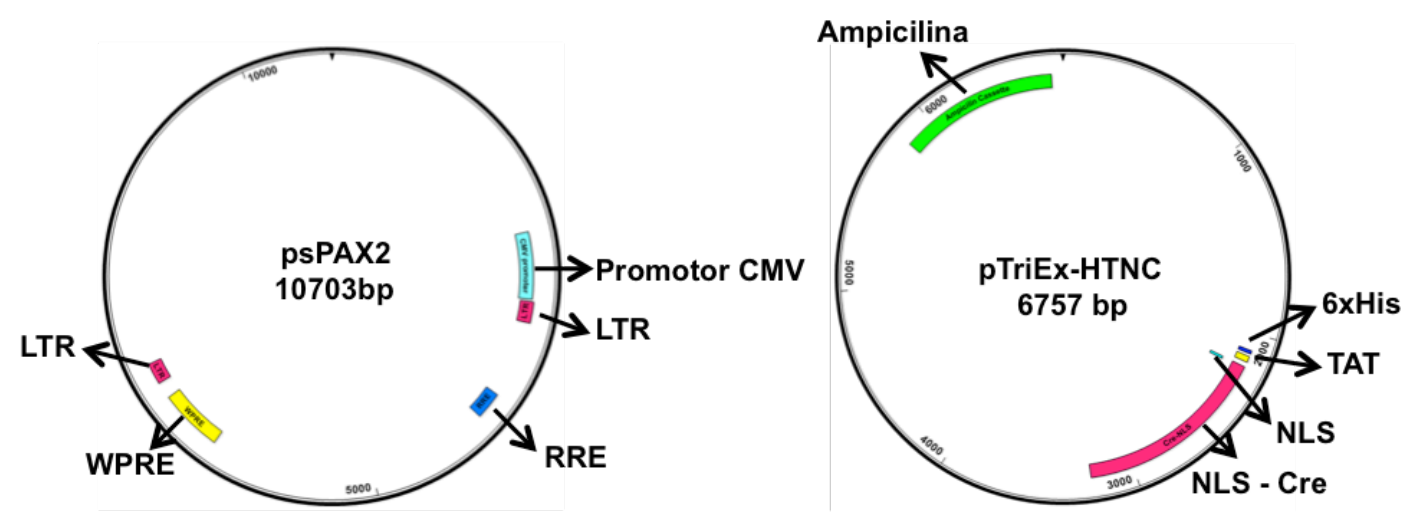

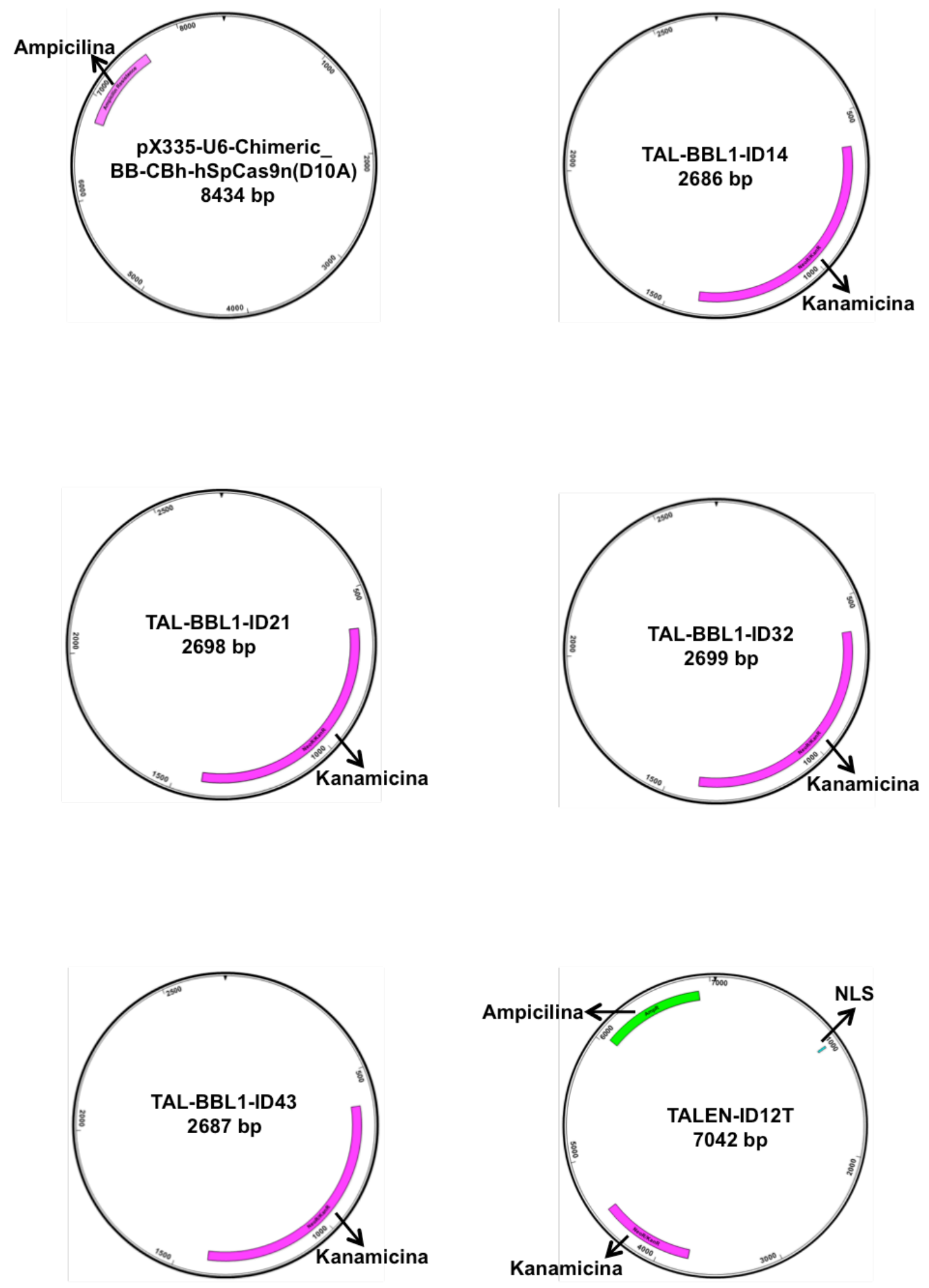


\section{Librería de siRNAs. Características de cada siRNA.}

\begin{tabular}{|c|c|c|}
\hline Gen. & Exón & SiRNA S y AS. \\
\hline $\begin{array}{c}\text { AMZ2. Archaelysin family } \\
\text { metallopeptidase } 2 .^{1}\end{array}$ & $6,7,8$ & $\begin{array}{l}\text { GGAAUUUACCGAAACCCGUtt } \\
\text { ACGGGUUUCGGUAAAUUCCca }\end{array}$ \\
\hline $\begin{array}{l}\text { ANKRD28. Ankyrin repeat } \\
\text { domain } 28 .{ }^{1}\end{array}$ & 28 & $\begin{array}{l}\text { CCGUUAUACCAACACCUCAtt } \\
\text { UGAGGUGUUGGUAUAACGGtt }\end{array}$ \\
\hline $\begin{array}{c}\text { ANP32E. Acidic nuclear } \\
\text { phosphoprotein } 32 \text { family, } \\
\text { member E. }{ }^{1}\end{array}$ & 4 & $\begin{array}{l}\text { CUGUUUAACUGUGAGAUCAtt } \\
\text { UGAUCUCACAGUUAAACAGgt }\end{array}$ \\
\hline $\begin{array}{c}\text { APOBEC1. Apolipoprotein B } \\
\text { mRNA editing enzyme, catalytic } \\
\text { polypeptide } 1 .{ }^{1}\end{array}$ & 3 & $\begin{array}{l}\text { CCAAUCACGUGGAAGUUAAtt } \\
\text { UUAACUUCCACGUGAUUGGtg }\end{array}$ \\
\hline $\begin{array}{l}\text { ARID1A. AT rich interactive } \\
\text { domain } 1 \mathrm{~A} \text { (SWI-like) }{ }^{1}{ }^{1}\end{array}$ & 11 & $\begin{array}{l}\text { GGAAACCUCUGGACCUCUAtt } \\
\text { UAGAGGUCCAGAGGUUUCCta }\end{array}$ \\
\hline $\begin{array}{c}\text { ATP8A1. ATPase, } \\
\text { aminophospholipid transporter } \\
\text { (APLT), class I, type 8A, } \\
\text { member } 1 .{ }^{1}\end{array}$ & N/D & $\begin{array}{l}\text { GCAUGAUACAGACAGCGCAtt } \\
\text { UGCGCUGUCUGUAUCAUGCtg }\end{array}$ \\
\hline ATXN3. Ataxin $3 .^{1}$ & 4,3 & $\begin{array}{l}\text { GAACUAAUCCUGUUCAACAtt } \\
\text { UGUUGAACAGGAUUAGUUCta }\end{array}$ \\
\hline $\begin{array}{l}\text { BIRC2. Baculoviral IAP repeat } \\
\text { containing } 2 .{ }^{1}\end{array}$ & 2 & $\begin{array}{l}\text { GGAUAACUGGAAACUAGGAtt } \\
\text { UCCUAGUUUCCAGUUAUCCag }\end{array}$ \\
\hline $\begin{array}{c}\text { BRAP. BRCA1 associated } \\
\text { protein. }{ }^{1}\end{array}$ & N/D & $\begin{array}{l}\text { GGAUGUGGACGGUAUGUCAtt } \\
\text { UGACAUACCGUCCACAUCCta }\end{array}$ \\
\hline $\begin{array}{c}\text { C5orf28. Chromosome } 5 \text { open } \\
\text { readind frame } 28 .{ }^{1}\end{array}$ & N/D & $\begin{array}{l}\text { CCUCUGUUAUUGAUGUAGAtt } \\
\text { UCUACAUCAAUAACAGAGGct }\end{array}$ \\
\hline $\begin{array}{c}\text { C14orf39. Chromosome } 14 \\
\text { open reading frame } 39 .{ }^{1}\end{array}$ & N/D & $\begin{array}{l}\text { GGAUACACGAAACUAUAAAtt } \\
\text { UUUAUAGUUUCGUGUAUCCta }\end{array}$ \\
\hline $\begin{array}{l}\text { CACYBP. Calcyclin binding } \\
\text { protein. }{ }^{1}\end{array}$ & 4 & $\begin{array}{l}\text { CCAUGAUUGUGAACAAUCUtt } \\
\text { AGAUUGUUCACAAUCAUGGag }\end{array}$ \\
\hline $\begin{array}{l}\text { CGRRF1. Cell growth regulator } \\
\text { with ring finger domain } 1 .^{1}\end{array}$ & 3 & $\begin{array}{l}\text { GUAUAGUGAAUAUCUCUAUtt } \\
\text { AUAGAGAUAUUCACUAUACag }\end{array}$ \\
\hline $\begin{array}{l}\text { CNGA1. Cyclic nucleotide } \\
\text { gated channel alpha } 1 .{ }^{1}\end{array}$ & $\mathrm{~N} / \mathrm{D}$ & $\begin{array}{l}\text { GAUUAACCAAGGUUGAGAAtt } \\
\text { UUCUCAACCUUGGUUAAUCtt }\end{array}$ \\
\hline
\end{tabular}

N/D: No determinado, es decir, según la base de datos utilizada, la secuencia puede corresponder a diferentes exones. $\left({ }^{1}\right)$ Silencer $®$ Select siRNAs (Ambion $\left.®\right)$. 


\begin{tabular}{|c|c|c|}
\hline Gen. & Exón & siRNA S y AS. \\
\hline $\begin{array}{l}\text { CNGA1. Cyclic nucleotide } \\
\text { gated channel alpha } 1 .{ }^{1}\end{array}$ & N/D & $\begin{array}{l}\text { GGAUUACGUAUCAGACAUAtt } \\
\text { UAUGUCUGAUACGUAAUCCaa }\end{array}$ \\
\hline $\begin{array}{l}\text { CREBBP. CREB binding } \\
\text { protein. }^{1}\end{array}$ & 18,19 & $\begin{array}{l}\text { CAGCUAUCAGAAUAGGUAUtt } \\
\text { AUACCUAUUCUGAUAGCUGta }\end{array}$ \\
\hline $\begin{array}{l}\text { CREBBP. CREB binding } \\
\text { protein. }^{1}\end{array}$ & 24,25 & $\begin{array}{l}\text { GAAUCUUUCCCAUAUCGAAtt } \\
\text { UUCGAUAUGGGAAAGAUUCag }\end{array}$ \\
\hline CUL3. Cullin $3 .^{1}$ & N/D & $\begin{array}{l}\text { CCAGCGUAAGAAUAACAGUtt } \\
\text { ACUGUUAUUCUUACGCUGGat }\end{array}$ \\
\hline $\begin{array}{l}\text { DCLK1. Doublecortin-like } \\
\text { kinase } 1 .{ }^{1}\end{array}$ & N/D & $\begin{array}{l}\text { CGAUAUAAAGUCGGAAGAAtt } \\
\text { UUCUUCCGACUUUAUAUCGtt }\end{array}$ \\
\hline $\begin{array}{l}\text { DCLRE1C. DNA cross-link } \\
\text { repair } 1 C^{1}{ }^{1}\end{array}$ & $\begin{array}{c}11,12,1 \\
3,14\end{array}$ & $\begin{array}{l}\text { GUCGAAAUCUUAAAGCCUUtt } \\
\text { AAGGCUUUAAGAUUUCGACaa }\end{array}$ \\
\hline $\begin{array}{l}\text { DDX17. DEAD (Asp-Glu-Ala- } \\
\text { Asp) polypeptide } 17 .^{1}\end{array}$ & N/D & $\begin{array}{l}\text { GAGAGACUCUGCAAGCUAUtt } \\
\text { AUAGCUUGCAGAGUCUCUCcg }\end{array}$ \\
\hline $\begin{array}{c}\text { DNAJB4. DnaJ (Hsp40) } \\
\text { homolog, subfamily B, member } \\
4 .^{1}\end{array}$ & 2 & $\begin{array}{l}\text { CCAGUUAUUCAUGAACUUAtt } \\
\text { UAAGUUCAUGAAUAACUGGag }\end{array}$ \\
\hline $\begin{array}{c}\text { DNAJB4. DnaJ (Hsp40) } \\
\text { homolog, subfamily B, member } \\
4 .^{1}\end{array}$ & 3 & $\begin{array}{l}\text { CUAUGUCAGUAAAUGAUAUtt } \\
\text { AUAUCAUUUACUGACAUAGgt }\end{array}$ \\
\hline $\begin{array}{l}\text { DENND4A. DENN/MADD } \\
\text { domain containing 4A. }{ }^{1}\end{array}$ & N/D & $\begin{array}{l}\text { GACUUUUCUGUAUCGUUAUtt } \\
\text { AUAACGAUACAGAAAAGUCag }\end{array}$ \\
\hline $\begin{array}{l}\text { DOCK10. Dedicator of } \\
\text { cytokinesis } 10 .^{1}\end{array}$ & 52 & $\begin{array}{l}\text { GGAAGACAGAUUUCGAAAUtt } \\
\text { AUUUCGAAAUCUGUCUUCCgg }\end{array}$ \\
\hline $\begin{array}{c}\text { E2F7. E2F transcription factor } \\
7 .{ }^{1}\end{array}$ & 6 & $\begin{array}{l}\text { CCAAGAUUGUCACUCUGGAtt } \\
\text { UCCAGAGUGACAAUCUUGGtt }\end{array}$ \\
\hline FRZB. Frizzled-related protein. ${ }^{1}$ & 3 & $\begin{array}{l}\text { CCUAUUUCCGGAACAAUUAtt } \\
\text { UAAUUGUUCCGGAAAUAGGtc }\end{array}$ \\
\hline $\begin{array}{l}\text { GCNT2. Glucosaminyl (N- } \\
\text { acetyl) transferase } 2, \text { I- } \\
\text { branching enzyme. }^{1}\end{array}$ & 3 & $\begin{array}{l}\text { GUAUUUGUAUCUAUGGAAAtt } \\
\text { UUUCCAUAGAUACAAAUACca }\end{array}$ \\
\hline $\begin{array}{l}\text { GEMIN6. Gem associated } \\
\text { protein } 6 .{ }^{1}\end{array}$ & 3 & $\begin{array}{l}\text { CAGCUCUAAUGAGAUUAUUtt } \\
\text { AAUAAUCUCAUUAGAGCUGct }\end{array}$ \\
\hline
\end{tabular}

N/D: No determinado, es decir, según la base de datos utilizada, la secuencia puede corresponder a diferentes exones. $\left({ }^{1}\right)$ Silencer $囚$ Select siRNAs (Ambion®). 


\begin{tabular}{|c|c|c|}
\hline Gen. & Exón & siRNA S y AS. \\
\hline $\begin{array}{l}\text { GLP2R. Glucagon-like peptide } \\
2 \text { receptor. }{ }^{1}\end{array}$ & $y$ & $\begin{array}{l}\text { GGACAACAAAUGGGAAUAAtt } \\
\text { UUAUUCCCAUUUGUUGUCCag }\end{array}$ \\
\hline $\begin{array}{l}\text { GPR82. G protein-coupled } \\
\text { receptor } 82 .{ }^{1}\end{array}$ & $N / D$ & $\begin{array}{l}\text { GAACCACAUUUAUUGGAUUtt } \\
\text { AAUCCAAUAAAUGUGGUUCca }\end{array}$ \\
\hline $\begin{array}{l}\text { GPR171. G protein-coupled } \\
\text { receptor } 171 .{ }^{1}\end{array}$ & $N / D$ & $\begin{array}{l}\text { GAUCUACCGAAUACAAGAAtt } \\
\text { UUCUUGUAUUCGGUAGAUCtt }\end{array}$ \\
\hline $\begin{array}{l}\text { GTF2H2C. General } \\
\text { transcription factor IIH, } \\
\text { polypeptide } 2 \mathrm{C} .^{1}\end{array}$ & 5 & $\begin{array}{l}\text { CAAGAACAAUGGAAGACCAtt } \\
\text { UGGUCUUCCAUUGUUCUUGat }\end{array}$ \\
\hline $\begin{array}{l}\text { HUWE1. HECT, UBA and WWE } \\
\text { domain } 1 .{ }^{1}\end{array}$ & $N / D$ & $\begin{array}{l}\text { CUGUGAGAGUGAUCGGGAAtt } \\
\text { UUCCCGAUCACUCUCACAGtt }\end{array}$ \\
\hline $\begin{array}{l}\text { ILKAP. Integrin-linked kinase- } \\
\text { associated serine/threonine } \\
\text { phosphatase. }{ }^{1}\end{array}$ & 6 & $\begin{array}{l}\text { GCAUCAAAACUUAAUCAGAtt } \\
\text { UCUGAUUAAGUUUUGAUGCaa }\end{array}$ \\
\hline 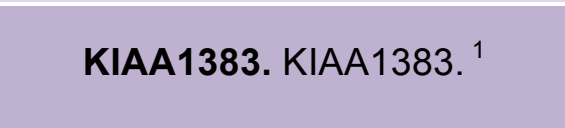 & $N / D$ & $\begin{array}{l}\text { GGCUUAACAAAUACACUAAtt } \\
\text { UUAGUGUAUUUGUUAAGCCat }\end{array}$ \\
\hline $\begin{array}{l}\text { LIG4. Ligase IV, DNA, ATP- } \\
\text { dependent. }^{1}\end{array}$ & 2,3 & $\begin{array}{l}\text { CCGUGAAUAUGAUUGCUAUtt } \\
\text { AUAGCAAUCAUAUUCACGGgC }\end{array}$ \\
\hline $\begin{array}{l}\text { LIG4. Ligase IV, DNA, ATP- } \\
\text { dependent. }{ }^{1}\end{array}$ & 2,3 & $\begin{array}{l}\text { CAUUGAACCUUGUAAUUCUtt } \\
\text { AGAAUUACAAGGUUCAAUGta }\end{array}$ \\
\hline $\begin{array}{l}\text { LIN54. Lin-54 homolog }(C . \\
\text { Elegans). }{ }^{1}\end{array}$ & 2 & $\begin{array}{l}\text { CAGUACAGAUUGCUAAGAAtt } \\
\text { UUCUUAGCAAUCUGUACUGtt }\end{array}$ \\
\hline LMNB2. Lamin B2. ${ }^{1}$ & 8 & $\begin{array}{l}\text { GAACAACUCGGACAAGGAUtt } \\
\text { AUCCUUGUCCGAGUUGUUCtt }\end{array}$ \\
\hline $\begin{array}{c}\text { LOC146795. } \\
\text { Hypothetical protein } \\
\text { LOC } 146795 .^{1}\end{array}$ & $N / D$ & $\begin{array}{l}\text { GAGAAAUACUGACCAACAAtt } \\
\text { UUGUUGGUCAGUAUUUCUCtt }\end{array}$ \\
\hline $\begin{array}{l}\text { LYRM7. Lyrm7 homolog } \\
\text { (mouse). }{ }^{1}\end{array}$ & 2 & $\begin{array}{l}\text { CAGACAACAAGUUUUUAAAtt } \\
\text { UUUAAAAACUUGUUGUCUGgt }\end{array}$ \\
\hline $\begin{array}{l}\text { MAP3K19. Mitogen-activated } \\
\text { protein kinase kinase kinase } 19^{1}\end{array}$ & 3 & $\begin{array}{l}\text { CCACACUGGUUAAUGAAGAtt } \\
\text { UCUUCAUUAACCAGUGUGGaa }\end{array}$ \\
\hline $\begin{array}{l}\text { MLH1. MutL homolog } 1 \text {, colon } \\
\text { cancer, nonpolyposis type } 2 .{ }^{1}\end{array}$ & $N / D$ & $\begin{array}{l}\text { GAAAUUGGAUGUGAGGAUAtt } \\
\text { UAUCCUCACAUCCAAUUUCta }\end{array}$ \\
\hline
\end{tabular}




\begin{tabular}{|c|c|c|}
\hline Gen. & Exón & siRNA S y AS. \\
\hline $\begin{array}{l}\text { MLH1. MutL homolog } 1 \text {, colon } \\
\text { cancer, nonpolyposis type } 2(E . \\
\text { Coli). }{ }^{1}\end{array}$ & N/D & $\begin{array}{l}\text { GCAUUAGUUUCUCAGUUAAtt } \\
\text { UUAACUGAGAAACUAAUGCct }\end{array}$ \\
\hline MMRN1. Multimerin $1 .^{1}$ & 2 & $\begin{array}{l}\text { CAGUGAUAUUGGACAACCAtt } \\
\text { UGGUUGUCCAAUAUCACUGtg }\end{array}$ \\
\hline $\begin{array}{l}\text { MSH2. MutS homolog 2, colon } \\
\text { cancer, nonpolyposis type } 1 \text { ( } E \text {. } \\
\text { Coli). }{ }^{1}\end{array}$ & 7 & $\begin{array}{l}\text { CGUCGAUUCCCAGAUCUUAtt } \\
\text { UAAGAUCUGGGAAUCGACGaa }\end{array}$ \\
\hline $\begin{array}{c}\text { NDUFAF7. NADH } \\
\text { dehydrogenase (ubiquinone) } \\
\text { complex I, assembly factor } 7 .{ }^{1}\end{array}$ & 6,8 & $\begin{array}{l}\text { GGAACUUUCUCAACGCAUUtt } \\
\text { AAUGCGUUGAGAAAGUUCCtc }\end{array}$ \\
\hline $\begin{array}{l}\text { NSL1. NSL1, MIS12 kinetochore } \\
\text { complex component. }{ }^{1}\end{array}$ & 7,6 & $\begin{array}{l}\text { CAGUUGUCAUAGGAAACCAtt } \\
\text { UGGUUUCCUAUGACAACUGga }\end{array}$ \\
\hline NUP153. nucleoporin $153 \mathrm{kDa} .{ }^{1}$ & 16 & $\begin{array}{l}\text { GCAUCGCCGAAGAUAGAUUtt } \\
\text { AAUCUAUCUUCGGCGAUGCga }\end{array}$ \\
\hline $\begin{array}{l}\text { OR2L13. Olfactory receptor, } \\
\text { family 2, subfamily } L \text {, member } \\
\qquad 13 .{ }^{1}\end{array}$ & 3 & $\begin{array}{l}\text { GCAGGUCUAGGGCUAUUGAtt } \\
\text { UCAAUAGCCCUAGACCUGCag }\end{array}$ \\
\hline PANK1. Pantothenate kinase $1 .{ }^{1}$ & 4,5 & $\begin{array}{l}\text { GCAACAUGAUGAGUAAAGAtt } \\
\text { UCUUUACUCAUCAUGUUGCca }\end{array}$ \\
\hline $\begin{array}{l}\text { PAPOLG. Poly(A) polymerase } \\
\text { gamma. }{ }^{1}\end{array}$ & 19 & $\begin{array}{l}\text { CCAUAGAUGGGACUCCUAAtt } \\
\text { UUAGGAGUCCCAUCUAUGGat }\end{array}$ \\
\hline $\begin{array}{l}\text { PDHX. Pyruvate dehydrogenase } \\
\text { complex, component } \text {. }^{1}\end{array}$ & N/D & $\begin{array}{l}\text { GUACUGUACCUCAUGCAUAtt } \\
\text { UAUGCAUGAGGUACAGUACtt }\end{array}$ \\
\hline $\begin{array}{l}\text { PIK3R1. Phosphoinositide-3- } \\
\text { kinase, regulatory subunit } 1 \\
\text { (alpha). }{ }^{1}\end{array}$ & 2 & $\begin{array}{l}\text { CAACGGUAUGAAUAACAAUtt } \\
\text { AUUGUUAUUCAUACCGUUGtt }\end{array}$ \\
\hline $\begin{array}{c}\text { PPP1R15A. Protein } \\
\text { phosphatase 1, regulatory } \\
\text { (inhibitor) subunit 15A. }{ }^{1}\end{array}$ & $\mathrm{~N} / \mathrm{D}$ & $\begin{array}{l}\text { GGAUCAGCCGAGGAUGAAAtt } \\
\text { UUUCAUCCUCGGCUGAUCCtg }\end{array}$ \\
\hline $\begin{array}{l}\text { PRIM1. Primase, DNA, } \\
\text { polypeptide } 1(49 \mathrm{kDa}){ }^{1}\end{array}$ & 1 & $\begin{array}{l}\text { CAACUACGGUGGAGUGAUAtt } \\
\text { UAUCACUCCACCGUAGUUGag }\end{array}$ \\
\hline
\end{tabular}

N/D: No determinado, es decir, según la base de datos utilizada, la secuencia puede corresponder a diferentes exones. $\left({ }^{1}\right)$ Silencer ${ }^{\circledR}$ Select siRNAs $($ Ambion®). 


\begin{tabular}{|c|c|c|}
\hline Gen. & Exón & SiRNA S y AS. \\
\hline $\begin{array}{l}\text { PRKDC. Protein kinase, DNA- } \\
\text { activated, catalytic polypeptide. }^{1}\end{array}$ & 31 & $\begin{array}{l}\text { GCGUUGGAGUGCUACAACAtt } \\
\text { UGUUGUAGCACUCCAACGCgg }\end{array}$ \\
\hline $\begin{array}{l}\text { PSMA7. Proteasome subunit, } \\
\text { alpha type, } 7 .{ }^{1}\end{array}$ & 2 & $\begin{array}{l}\text { AGAACAGUGCGGAAGAUCUtt } \\
\text { AGAACAGUGCGGAAGAUCUtt }\end{array}$ \\
\hline $\begin{array}{l}\text { RAD51. RAD51 homolog (RecA } \\
\text { homolog, E. coli) (S. } \\
\text { Cerevisiae). }{ }^{1}\end{array}$ & $N / D$ & $\begin{array}{l}\text { GGUAGAAUCUAGGUAUGCAtt } \\
\text { UGCAUACCUAGAUUCUACCat }\end{array}$ \\
\hline RAl1. Retinoic acid induced $1{ }^{1}$ & 3 & $\begin{array}{l}\text { CCAACCAACAGAUCCUUAAtt } \\
\text { UUAAGGAUCUGUUGGUUGGat }\end{array}$ \\
\hline $\begin{array}{l}\text { RGS12. Regulator of G-protein } \\
\text { signaling } 12 .{ }^{1}\end{array}$ & 5,7 & $\begin{array}{l}\text { CCCGGGAGAUUUUCAGUAAtt } \\
\text { UUACUGAAAAUCUCCCGGGcC }\end{array}$ \\
\hline $\begin{array}{c}\text { RPS6KA5. Ribosomal protein } \\
\text { S6 kinase, 90kDa, polypeptide } \\
5 .{ }^{1}\end{array}$ & 7 & $\begin{array}{l}\text { GCUGAGAUAUCUAGGAGAAtt } \\
\text { UUCUCCUAGAUAUCUCAGCtt }\end{array}$ \\
\hline $\begin{array}{l}\text { RPS6KA5. Ribosomal protein } \\
\text { S6 kinase, 90kDa, polypeptide } \\
5 .{ }^{1}\end{array}$ & 12 & $\begin{array}{l}\text { GGAAAUAACAGCUCUGAAAtt } \\
\text { UUUCAGAGCUGUUAUUUCCtt }\end{array}$ \\
\hline $\begin{array}{l}\text { SFR1. SWI5-dependent } \\
\text { recombination repair } 1 .{ }^{1}\end{array}$ & 2 & $\begin{array}{l}\text { CAUCAUCUCCCUAUACAAAtt } \\
\text { UUUGUAUAGGGAGAUGAUGga }\end{array}$ \\
\hline $\begin{array}{l}\text { SFR1. SWI5-dependent } \\
\text { recombination repair } 1 .{ }^{1}\end{array}$ & 4 & $\begin{array}{l}\text { CAGUUACAGUUGUUAAUAAtt } \\
\text { UUAUUAACAACUGUAACUGag }\end{array}$ \\
\hline $\begin{array}{l}\text { SiSel_NC1. Silencer Select } \\
\text { Negative Control \#1 siRNA. }{ }^{1}\end{array}$ & $N / D$ & $\begin{array}{l}\text { UAACGACGCGACGACGUAAtt } \\
\text { UUACGUCGUCGCGUCGUUAtt }\end{array}$ \\
\hline $\begin{array}{l}\text { SLC8A1. Slute carrier family } 8 \\
\text { (sodium/calcium exchanger), } \\
\text { member } 1 .{ }^{1}\end{array}$ & 1 & $\begin{array}{l}\text { GCUAACUACCAAGUCCUAAtt } \\
\text { UUAGGACUUGGUAGUUAGCta }\end{array}$ \\
\hline $\begin{array}{l}\text { SLC39A12. Solute carrier } \\
\text { family } 39 \text { (zinc transporter), } \\
\text { member } 12 .^{1}\end{array}$ & $N / D$ & $\begin{array}{l}\text { CAGAAGUACUUGUAUCAAAtt } \\
\text { UUUGAUACAAGUACUUCUGgt }\end{array}$ \\
\hline $\begin{array}{c}\text { SMAD1. SMAD family member } \\
1 .{ }^{1}\end{array}$ & 6 & $\begin{array}{l}\text { CAGUCUAUGAGCUUACAAAtt } \\
\text { UUUGUAAGCUCAUAGACUGtc }\end{array}$ \\
\hline $\begin{array}{l}\text { SMAD5. SMAD family member } \\
5 .{ }^{1}\end{array}$ & $2,3,4$ & $\begin{array}{l}\text { GCAGAGUCAUCAUGAGCUAtt } \\
\text { UAGCUCAUGAUGACUCUGCaa }\end{array}$ \\
\hline
\end{tabular}

N/D: No determinado, es decir, según la base de datos utilizada, la secuencia puede corresponder a diferentes exones. $\left({ }^{1}\right)$ Silencer $\circledR$ Select siRNAs (Ambion®). 


\begin{tabular}{|c|c|c|}
\hline Gen. & Exón & siRNA S y AS. \\
\hline $\begin{array}{c}\text { SMCHD1. Structural } \\
\text { maintenance of chromosomes } \\
\text { flexible hinge domain containing } \\
1 .{ }^{1}\end{array}$ & N/D & $\begin{array}{l}\text { GGAUCUUCCUUUUCGUGUUtt } \\
\text { AACACGAAAAGGAAGAUCCag }\end{array}$ \\
\hline $\begin{array}{c}\text { SMCHD1. Structural } \\
\text { maintenance of chromosomes } \\
\text { flexible hinge domain containing } \\
1 .{ }^{1}\end{array}$ & N/D & $\begin{array}{l}\text { CCUAAGAUUGUCAACCUAAtt } \\
\text { UUAGGUUGACAAUCUUAGGta }\end{array}$ \\
\hline $\begin{array}{l}\text { SPESP1. Sperm equatorial } \\
\text { segment protein } 1 .{ }^{1}\end{array}$ & 2 & $\begin{array}{l}\text { GUGUAAUUCUAGAUCUAAAtt } \\
\text { UUUAGAUCUAGAAUUACACag }\end{array}$ \\
\hline STAG2. Stromal antigen $2 .^{1}$ & 6,5 & $\begin{array}{l}\text { GGUAGAUGAUUGGAUAGAAtt } \\
\text { UUCUAUCCAAUCAUCUACCac }\end{array}$ \\
\hline $\begin{array}{l}\text { SUM01. SMT3 suppressor of mif } \\
\text { two } 3 \text { homolog } 1 \text { ( } S \text {. Cerevisiae). }\end{array}$ & 2,3 & $\begin{array}{l}\text { CAAGAAACUCAAAGAAUCAtt } \\
\text { UGAUUCUUUGAGUUUCUUGag }\end{array}$ \\
\hline $\begin{array}{l}\text { TAF1. TAF1 RNA polymerase II, } \\
\text { TATA box binding protein (TBP)- } \\
\text { associated factor, } 250 \mathrm{kDa}{ }^{1}\end{array}$ & N/D & $\begin{array}{l}\text { CACUGUUCACUGUGACUAUtt } \\
\text { AUAGUCACAGUGAACAGUGgt }\end{array}$ \\
\hline $\begin{array}{l}\text { TAF4. TAF4 RNA polymerase II, } \\
\text { TATA box binding protein (TBP)- } \\
\text { associated factor, } 135 \mathrm{kDa} .{ }^{1}\end{array}$ & 3 & $\begin{array}{l}\text { CAACUACCAUAAUUAAGCAtt } \\
\text { UGCUUAAUUAUGGUAGUUGgg }\end{array}$ \\
\hline $\begin{array}{l}\text { TAF4. TAF4 RNA polymerase II, } \\
\text { TATA box binding protein (TBP)- } \\
\text { associated factor, } 135 \mathrm{kDa}{ }^{1}\end{array}$ & 6 & $\begin{array}{l}\text { GGUUAUACCGAGAACUUAAtt } \\
\text { UUAAGUUCUCGGUAUAACCtg }\end{array}$ \\
\hline $\begin{array}{l}\text { TERT. Telomerase reverse } \\
\text { transcriptase. }^{1}\end{array}$ & 11 & $\begin{array}{l}\text { GCACGGCUUUUGUUCAGAUtt } \\
\text { AUCUGAACAAAAGCCGUGCca }\end{array}$ \\
\hline TFEC. Transcription factor EC. ${ }^{1}$ & 3,4 & $\begin{array}{l}\text { GUCUACCAAUGAAAAGAGAtt } \\
\text { UCUCUUUUCAUUGGUAGACta }\end{array}$ \\
\hline TH. Tyrosine hydroxylase. ${ }^{1}$ & N/D & $\begin{array}{l}\text { GCUCAGGAGCUAUGCCUCAtt } \\
\text { UGAGGCAUAGCUCCUGAGCtt }\end{array}$ \\
\hline $\begin{array}{l}\text { USP12. Ubiquitin specific } \\
\text { peptidase } 12{ }^{1}\end{array}$ & N/D & $\begin{array}{l}\text { GAACUUCGUCUGUUUAACAtt } \\
\text { UGUUAAACAGACGAAGUUCta }\end{array}$ \\
\hline
\end{tabular}

N/D: No determinado, es decir, según la base de datos utilizada, la secuencia puede corresponder a diferentes exones. $(1)$ Silencer® Select siRNAs (Ambion®). 


\begin{tabular}{|c|c|c|}
\hline Gen. & Exón & siRNA S y AS. \\
\hline $\begin{array}{l}\text { WRB. Tryptophan rich basic } \\
\text { protein. }{ }^{1}\end{array}$ & $N / D$ & $\begin{array}{l}\text { GGGUGAUAAGUGUCGCUUUtt } \\
\text { AAAGCGACACUUAUCACCCat }\end{array}$ \\
\hline $\begin{array}{l}\text { WRB. Tryptophan rich basic } \\
\text { protein. }^{1}\end{array}$ & $N / D$ & $\begin{array}{l}\text { CGGAUAAGCUCAAAACCCAtt } \\
\text { UGGGUUUUGAGCUUAUCCGtc }\end{array}$ \\
\hline $\begin{array}{c}\text { XRCC2. X-ray repair } \\
\text { complementing defective repair } \\
\text { in Chinese hamster cells } 2 .{ }^{1}\end{array}$ & 3 & $\begin{array}{l}\text { GAGAAAGUGUGAACUUACAtt } \\
\text { UGUAAGUUCACACUUUCUCct }\end{array}$ \\
\hline $\begin{array}{c}\text { XRCC4. X-ray repair } \\
\text { complementing defective repair } \\
\text { in Chinese hamster cells } 4 .^{1}\end{array}$ & $N / D$ & $\begin{array}{l}\text { GUCUUGAUGUCACUGAUAUtt } \\
\text { AUAUCAGUGACAUCAAGACtt }\end{array}$ \\
\hline $\begin{array}{c}\text { XRCC6. X-ray repair } \\
\text { complementing defective repair } \\
\text { in Chinese hamster cells } 6 .^{2}\end{array}$ & $N / D$ & $\begin{array}{l}\text { GACAUGAUGGGCCACGGAU } \\
\text { AUCCGUGGCCCAUCAUGUC }\end{array}$ \\
\hline $\begin{array}{c}\text { XRCC6. X-ray repair } \\
\text { complementing defective repair } \\
\text { in Chinese hamster cells } 6 .^{2}\end{array}$ & $N / D$ & $\begin{array}{l}\text { GUUCUAUGGUACCGAGAAA } \\
\text { UUUCUCGGUACCAUAGAAC }\end{array}$ \\
\hline $\begin{array}{l}\text { XRCC6BP1. XRCC6 binding } \\
\text { protein. }^{2}\end{array}$ & $N / D$ & $\begin{array}{l}\text { CACACACGAGCUUAUUCAU } \\
\text { AUGAAUAAGCUCGAGUGUG }\end{array}$ \\
\hline $\begin{array}{l}\text { XRCC6BP1. XRCC6 binding } \\
\text { protein. }^{1}\end{array}$ & 6 & $\begin{array}{l}\text { ACAAGACUUAUGCAAGAUAtt } \\
\text { UAUCUUGCAUAAGUCUUGUta }\end{array}$ \\
\hline $\begin{array}{l}\text { XRCC6BP1. XRCC6 binding } \\
\text { protein. }^{3}\end{array}$ & N/D & $\begin{array}{l}\text { GGAUCCCACAUAACAAGA } \\
\text { GCAUAAGUCUUGUUAUGU }\end{array}$ \\
\hline ZFN223. Zinc finger $223{ }^{1}$ & $N / D$ & $\begin{array}{l}\text { GAGCUACAUUACUAAGUCAtt } \\
\text { UGACUUAGUAAUGUAGCUCtt }\end{array}$ \\
\hline $\begin{array}{c}\text { ZFN454. Zinc finger protein } 454 . \\
1\end{array}$ & 5 & $\begin{array}{l}\text { GGAUUUCAACCUAGCAAAAtt } \\
\text { UUUUGCUAGGUUGAAAUCCct }\end{array}$ \\
\hline $\begin{array}{l}\text { ZRSR2. Zinc finger RNA-binding } \\
\text { motif and serine/arginine rich } 2 .{ }^{1}\end{array}$ & 7 & $\begin{array}{l}\text { GAUGUUCACGUAAACAUAAtt } \\
\text { UUAUGUUUACGUGAACAUCta }\end{array}$ \\
\hline $\begin{array}{l}\text { ZRSR2. Zinc finger RNA-binding } \\
\text { motif and serine/arginine rich } 2{ }^{1}\end{array}$ & 9 & $\begin{array}{l}\text { GCAAUGUAUAUGUUCAGUAtt } \\
\text { UACUGAACAUAUACAUUGCCC }\end{array}$ \\
\hline
\end{tabular}

N/D: No determinado, es decir, según la base de datos utilizada, la secuencia puede corresponder a diferentes exones.

Silencer Select siRNA (Ambion). ${ }^{2}$ siRNA (Sigma-Aldrich). ${ }^{3}$ RNAi (IDT) 


\section{Datos estadísticos obtenidos en los diferentes experimentos} realizados.

Los datos estadísticos de los resultados obtenidos se realizaron mediante la utilización del programa informatico EXCEL. De esta manera se calcularon la media de los experimentos, la desviación estándar de los mismos y la t de Student para conocer si los datos obtenidos son estadísticamente significativos.

\subsection{ScRad52.}

\begin{tabular}{|c|c|c|c|}
\hline Proteína & $\begin{array}{c}\text { Media los } \\
\text { experimentos }\end{array}$ & $\begin{array}{c}\text { Desviación } \\
\text { estándar }\end{array}$ & t de Student \\
\hline ScRad52 & 45,3 & 7,6 & 0,000000005 \\
\hline Control & 23,2 & 3,4 & - \\
\hline
\end{tabular}

\subsection{Librería de siRNAs.}

\begin{tabular}{|c|c|c|c|}
\hline siRNAs & $\begin{array}{c}\text { Media los } \\
\text { experimentos }\end{array}$ & $\begin{array}{c}\text { Desviación } \\
\text { estándar }\end{array}$ & t de Student \\
\hline AMZ2 & 29,7 & 3,5 & 0,00007 \\
\hline ANKRD28 & 37,0 & 4,0 & 0,002 \\
\hline ANP32E & 31,3 & 3,2 & 0,0001 \\
\hline APOBEC1 & 26,3 & 3,1 & 0,00002 \\
\hline ARID1A & 31,0 & 5,3 & 0,0003 \\
\hline ATP8A1 & 28,3 & 7,4 & 0,0005 \\
\hline ATXN3 & 23,3 & 4,2 & 0,00002 \\
\hline BIRC2 & 50,0 & 3,6 & 0,6 \\
\hline BRAP & 47,0 & 2,6 & 0,4 \\
\hline C50rf28 & 34,0 & 4,6 & 0,0006 \\
\hline C140rf39 & 28,0 & 1,0 & 0,00001 \\
\hline CACYBP & 51,3 & 2,5 & 0,3 \\
\hline CGRRF1 & 62,0 & 4,4 & 0,001 \\
\hline CNGA1 & 66,7 & 4,2 & 0,0001 \\
\hline CREBBP & 90,0 & 4,0 & 0,0000006 \\
\hline
\end{tabular}




\begin{tabular}{|c|c|c|c|}
\hline siRNAs & $\begin{array}{c}\text { Media los } \\
\text { experimentos }\end{array}$ & $\begin{array}{c}\text { Desviación } \\
\text { estándar }\end{array}$ & t de Student \\
\hline CUL3 & 47,3 & 3,8 & 0,5 \\
\hline DCLK1 & 53,3 & 3,1 & 0,08 \\
\hline DCLRE1C & 30,3 & 2,1 & 0,00004 \\
\hline DDX17 & 24,7 & 4,0 & 0,00002 \\
\hline DNAJB4 & 76,7 & 3,1 & 0,000004 \\
\hline DENND4A & 29,3 & 6,7 & 0,0004 \\
\hline DOCK10 & 63,3 & 5,8 & 0,001 \\
\hline E2F7 & 26,0 & 2,6 & 0,00001 \\
\hline FRZB & 59,7 & 6,4 & 0,009 \\
\hline GCNT2 & 49,3 & 2,3 & 0,8 \\
\hline GEMIN6 & 28,0 & 6,2 & 0,0002 \\
\hline GLP2R & 45,7 & 5,1 & 0,3 \\
\hline GPR82 & 60,0 & 8,2 & 0,02 \\
\hline GPR171 & 54,0 & 4,0 & 0,07 \\
\hline GTF2H2C & 21,7 & 4,5 & 0,00001 \\
\hline HUWE1 & 51,0 & 6,6 & 0,5 \\
\hline ILKAP & 64,3 & 5,1 & 0,0007 \\
\hline KIAA1383 & 49,0 & 2,6 & 0,9 \\
\hline LIG4 & 69,0 & 5,3 & 0,0001 \\
\hline LIN54 & 25,7 & 2,5 & 0,00001 \\
\hline LMNB2 & 64,0 & 5,3 & 0,0009 \\
\hline LOC146795 & 50,7 & 7,1 & 0,6 \\
\hline LYRM7 & 30,7 & 2,1 & 0,00004 \\
\hline MAP3K19 & 46,0 & 3,6 & 0,3 \\
\hline MLH1 & 73,0 & 2,0 & 0,000006 \\
\hline MMRN1 & 26,7 & 3,5 & 0,00003 \\
\hline MSH2 & 20,7 & 2,3 & 0,000003 \\
\hline NDUFAF7 & 43,7 & 4,0 & 0,07 \\
\hline NSL1 & 53,3 & 6,1 & 0,2 \\
\hline NUP153 & 8,7 & 3,2 & 0,0000004 \\
\hline OR2L13 & 54,7 & 4,9 & 0,06 \\
\hline PANK1 & 42,7 & 2,5 & 0,02 \\
\hline
\end{tabular}


ANEXOS.

\begin{tabular}{|c|c|c|c|}
\hline siRNAs & $\begin{array}{c}\text { Media los } \\
\text { experimentos }\end{array}$ & $\begin{array}{c}\text { Desviación } \\
\text { estándar }\end{array}$ & t de Student \\
\hline PAPOLG & 15 & 4,6 & 0,000003 \\
\hline PDHX & 27,3 & 3,0 & 0,00002 \\
\hline PIK3R1 & 62,3 & 14,3 & 0,05 \\
\hline PPP1R15A & 63,7 & 9,1 & 0,007 \\
\hline PRIM1 & 22,7 & 6,0 & 0,00005 \\
\hline PRKDC & 9,7 & 4,0 & 0,0000008 \\
\hline PSMA7 & 7 & 2,0 & 0,0000001 \\
\hline RAD51 & 41,3 & 1,5 & 0,006 \\
\hline RGS12 & 49,0 & 3,5 & 0,9 \\
\hline RPS6KA5 & 74,7 & 7,4 & 0,0001 \\
\hline SFR1 & 72,7 & 6,4 & 0,0001 \\
\hline SLC8A1 & 55,0 & 6,1 & 0,08 \\
\hline SLC39A12 & 12,7 & 2,3 & 0,0000005 \\
\hline SMAD1 & 44,7 & 7,5 & 0,3 \\
\hline SMAD5 & 51,3 & 5,9 & 0,4 \\
\hline SMCHD1 & 74,0 & 8,9 & 0,0003 \\
\hline SPESP1 & 9,0 & 4,4 & 0,0000009 \\
\hline STAG2 & 29,3 & 2,3 & 0,00003 \\
\hline SUMO1 & 19,7 & 5,0 & 0,00001 \\
\hline TAF1 & 38,3 & 1,1 & 0,0009 \\
\hline TAF4 & 65,7 & 8,1 & 0,002 \\
\hline TERT & 51,7 & 2,5 & 0,2 \\
\hline TFEC & 20,7 & 3,0 & 0,000004 \\
\hline TH & 60,3 & 5,1 & 0,004 \\
\hline USP12 & 20,0 & 4,0 & 0,000006 \\
\hline WRB & 64,3 & 8,3 & 0,004 \\
\hline XRCC2 & 25,7 & 11,0 & 0,001 \\
\hline XRCC4 & 22,3 & 5,5 & 0,00003 \\
\hline XRCC6 & 92,3 & 3,5 & 0,0000003 \\
\hline XRCC6BP1 & 90,3 & 4,9 & 0,000001 \\
\hline ZNF223 & 61,3 & 9,9 & 0,02 \\
\hline ZNF454 & 18,0 & 2,0 & 0,000001 \\
\hline
\end{tabular}


ANEXOS.

\begin{tabular}{|c|c|c|c|}
\hline siRNAs & $\begin{array}{c}\text { Media los } \\
\text { experimentos }\end{array}$ & $\begin{array}{c}\text { Desviación } \\
\text { estándar }\end{array}$ & t de Student \\
\hline ZRSR2 & 61,7 & 1,5 & 0,0003 \\
\hline ZRSR2 & 60 & 2,0 & 0,0009 \\
\hline siRNA C- & 47,7 & 2,0 & - \\
\hline Control & 50,0 & 4,0 & - \\
\hline
\end{tabular}

3.3 siRNAs de comprobación.

\begin{tabular}{|c|c|c|c|}
\hline siRNAs & $\begin{array}{c}\text { Media los } \\
\text { experimentos }\end{array}$ & $\begin{array}{c}\text { Desviación } \\
\text { estándar }\end{array}$ & t de Student \\
\hline XRCC6BP1 & 56,7 & 4,7 & 0,00002 \\
\hline CNGA1 & 55,3 & 3,2 & 0,000009 \\
\hline CREBBP & 71,7 & 3,5 & 0,0000002 \\
\hline DNAJB4 & 60,0 & 5,6 & 0,00002 \\
\hline LIG4 & 58,3 & 6,5 & 0,00007 \\
\hline SMCHD1 & 62,3 & 5,1 & 0,000008 \\
\hline WRB & 66,0 & 3,6 & 0,0000008 \\
\hline MLH1 & 52,7 & 5,9 & 0,0002 \\
\hline TAF4 & 54,0 & 1,7 & 0,000004 \\
\hline RPS6KA5 & 56,3 & 5,0 & 0,00003 \\
\hline SFR1 & 60,3 & 3,5 & 0,000003 \\
\hline XRCC6 & 71,3 & 1,5 & 0,00000004 \\
\hline siRNA C- & 34,3 & 2,5 & - \\
\hline Control & 35,3 & 2,3 & - \\
\hline
\end{tabular}

3.4 Combinaciones de 2 siRNAs.

\begin{tabular}{|c|c|c|c|}
\hline $\begin{array}{c}\text { siRNAs } \text { I } \\
\text { Combinaciones }\end{array}$ & $\begin{array}{c}\text { Media los } \\
\text { experimentos }\end{array}$ & $\begin{array}{c}\text { Desviación } \\
\text { estándar }\end{array}$ & t de Student \\
\hline XRCC6 + CNGA1 & 27,3 & 2,5 & 0,0000006 \\
\hline XRCC6 + CREBBP & 109,3 & 5,5 & 0,00000009 \\
\hline XRCC6 + DNAJB4 & 58,3 & 6,5 & 0,2 \\
\hline XRCC6 + LIG4 & 66,7 & 2,1 & 0,00008 \\
\hline XRCC6 + SMCHD1 & 56,7 & 1,5 & 0,1 \\
\hline
\end{tabular}


ANEXOS.

\begin{tabular}{|c|c|c|c|}
\hline $\begin{array}{c}\text { siRNAs I } \\
\text { Combinaciones }\end{array}$ & $\begin{array}{c}\text { Media los } \\
\text { experimentos }\end{array}$ & $\begin{array}{c}\text { Desviación } \\
\text { estándar }\end{array}$ & t de Student \\
\hline XRCC6 + WRB & 81,3 & 5,7 & 0,00001 \\
\hline XRCC6 + MLH1 & 63,7 & 4,0 & 0,002 \\
\hline XRCC6 + TAF4 & 54,0 & 5,3 & 0,9 \\
\hline XRCC6 + RPS6KA5 & 42,7 & 8,5 & 0,01 \\
\hline XRCC6 + SFR1 & 78,3 & 6,1 & 0,00004 \\
\hline XRCC6 & 87,3 & 2,0 & 0,0000001 \\
\hline CREBBP + CNGA1 & 68,7 & 6,5 & 0,001 \\
\hline CREBBP + DNAJB4 & 87,7 & 6,0 & 0,000004 \\
\hline CREBBP + LIG4 & 88,0 & 2,0 & 0,00000009 \\
\hline CREBBP + SMCHD1 & 58,3 & 5,0 & 0,1 \\
\hline CREBBP + WRB & 82,7 & 2,1 & 0,0000003 \\
\hline CREBBP + MLH1 & 89,7 & 7,5 & 0,000009 \\
\hline CREBBP + TAF4 & 105,3 & 4,5 & 0,00000006 \\
\hline CREBBP + RPS6KA5 & 110,7 & 5,0 & 0,00000005 \\
\hline CREBBP + SFR1 & 128,0 & 1,7 & 0,0000000003 \\
\hline CREBBP & 90,0 & 1,0 & 0,00000003 \\
\hline siRNA C- & 53,3 & 2,1 & - \\
\hline Control & 55,3 & 2,1 & - \\
\hline
\end{tabular}

3.5 Combinaciones de 3 siRNAs.

\begin{tabular}{|c|c|c|c|}
\hline $\begin{array}{c}\text { siRNAs I } \\
\text { Combinaciones }\end{array}$ & $\begin{array}{c}\text { Media los } \\
\text { experimentos }\end{array}$ & $\begin{array}{c}\text { Desviación } \\
\text { estándar }\end{array}$ & t de Student \\
\hline $\begin{array}{c}\text { DNAJB4 + LIG4 + } \\
\text { XRCC6 }\end{array}$ & 82,7 & 2,1 & 0,00004 \\
\hline $\begin{array}{c}\text { DNAJB4 + CREBBP + } \\
\text { XRCC6 }\end{array}$ & 64,3 & 1,4 & 0,9 \\
\hline $\begin{array}{c}\text { DNAJB4 + LIG4 + } \\
\text { CREBBP }\end{array}$ & 57,3 & 1,4 & 0,0007 \\
\hline siRNA C- & 64 & 1,4 & - \\
\hline Control & 65 & 0,7 & - \\
\hline
\end{tabular}


ANEXOS.

3.6 Combinaciones de 4 siRNAs.

\begin{tabular}{|c|c|c|c|}
\hline $\begin{array}{c}\text { siRNAs I } \\
\text { Combinaciones }\end{array}$ & $\begin{array}{c}\text { Media los } \\
\text { experimentos }\end{array}$ & $\begin{array}{c}\text { Desviación } \\
\text { estándar }\end{array}$ & t de Student \\
\hline $\begin{array}{c}\text { DNAJB4 + LIG4 + } \\
\text { XRCC6 + CREBBP }\end{array}$ & 62,0 & 1,4 & 0,3 \\
\hline siRNA C- & 59,0 & 1,4 & - \\
\hline Control & 60,0 & 2,1 & - \\
\hline
\end{tabular}

